Routledge Contemporary Africa Series

\title{
DECOLONISING POLITICAL COMMUNICATION IN AFRICA REFRAMING ONTOLOGIES
}

\author{
Edited by
}

Beschara Karam and Bruce Mutsvairo

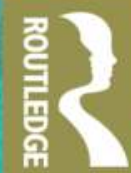




\section{Decolonising Political \\ Communication in Africa}

This book uses decolonisation as a lens to interrogate political communication styles, performance, and practice in Africa and the diaspora.

The book interrogates the theory and practice of political communication, using decolonial research methods to begin a process of self-reflexivity and the creation of a new approach to knowledge production about African political communication. In doing so, it explores political communication approaches that might until recently have been considered subversive or dissident: forms of political communication that served to challenge imposed Western norms and to empower African citizens and their histories. Centring African scholarship, the book draws on case studies from across the continent, including Zimbabwe, South Africa, Nigeria, and Ghana.

This book will be of interest to students and scholars of politics, media, and communication in Africa.

Beschara Karam is a Professor of Media Studies at the University of South Africa.

Bruce Mutsvairo is a Professor of Journalism at Auburn University, USA. 


\section{Routledge Contemporary Africa Series}

\section{The East African Community}

Intraregional Integration and Relations with the EU

Edited by Jean-Marc Trouille, Helen Trouille and Penine Uwimbabazi

Regionalism, Security and Development in Africa

Edited by Ernest Aniche, Ikenna Alumona and Inocent Moyo

The Fourth Industrial Revolution and the Recolonisation of Africa

The Coloniality of Data

Everisto Benyera

Mobility in Contemporary Zimbabwean Literature in English

Crossing Borders, Transcending Boundaries

Magdalena Pfalzgraf

Advancing Sexual and Reproductive Health and Rights in Africa

Constraints and Opportunities

Edited by Ebenezer Durojaye, Gladys Mirugi-Mukundi

and Charles Ngwena

Africa in a Multilateral World

Afropolitan Dilemmas

Edited by Albert Kasanda and Marek Hrubec

Decolonising Political Communication in Africa

Reframing Ontologies

Edited by Beschara Karam and Bruce Mutsvairo

For more information about this series, please visit: https://www.routledge. com/Routledge-Contemporary-Africa/book-series/RCAFR 


\title{
Decolonising Political Communication in Africa
}

Reframing Ontologies

\author{
Edited by \\ Beschara Karam and \\ Bruce Mutsvairo
}

(2) $\begin{aligned} & \text { Routledge } \\ & \text { Taylor \& Francis Group } \\ & \text { LONDON AND NEWYORK }\end{aligned}$ 
First published 2022

by Routledge

2 Park Square, Milton Park, Abingdon, Oxon OX14 4RN

and by Routledge

605 Third Avenue, New York, NY 10158

Routledge is an imprint of the Taylor \& Francis Group, an informa business

(C) 2022 selection and editorial matter, Beschara Karam and Bruce

Mutsvairo; individual chapters, the contributors

The right of Beschara Karam and Bruce Mutsvairo to be identified as the authors of the editorial material, and of the authors for their individual chapters, has been asserted in accordance with sections 77 and 78 of the Copyright, Designs and Patents Act 1988.

The Open Access version of this book, available at www.

taylorfrancis.com, has been made available under a Creative

Commons Attribution-Non Commercial-No Derivatives 4.0 license.

Trademark notice: Product or corporate names may be trademarks or registered trademarks, and are used only for identification and explanation without intent to infringe.

British Library Cataloguing-in-Publication Data

A catalogue record for this book is available from the British Library

Library of Congress Cataloging-in-Publication Data

A catalog record has been requested for this book

ISBN: 978-0-367-54430-0 (hbk)

ISBN: 978-0-367-63031-7 (pbk)

ISBN: 978-1-003-11196-2 (ebk)

DOI: $10.4324 / 9781003111962$

Typeset in Times New Roman

by codeMantra 
This book is dedicated to my beloved husband, MKH; and my darling parents, MM and DD. (Beschara Karam) 

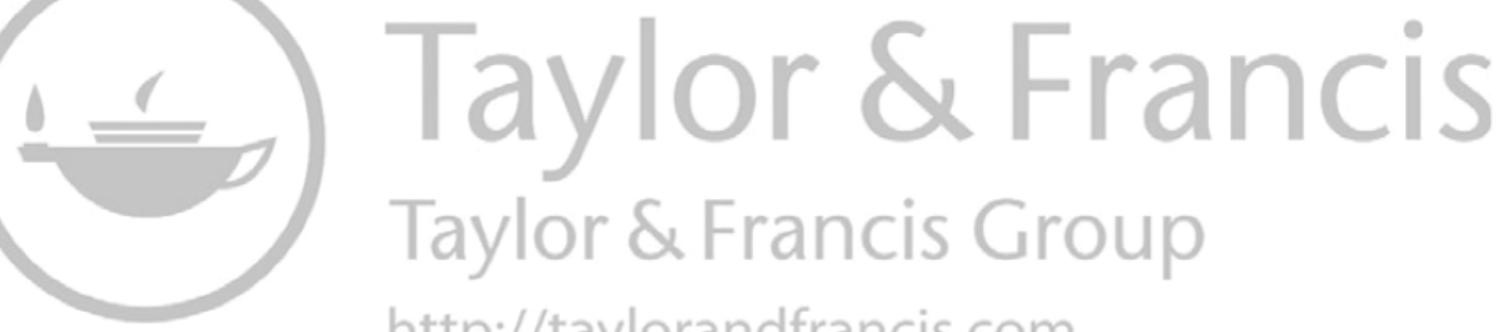

http://taylorandfrancis.com 


\section{Contents}

List of figures $x i$

List of tables xiii

Notes on contributors $x v$

Acknowledgements xxi

Foreword: Political communication for upending colonialism and its legacies $\quad x x i i i$

COLIN CHASI

1 Reframing African ontologies in the era of decolonisation 1 BESCHARA KARAM AND BRUCE MUTSVAIRO

\section{PART I}

Decolonial research

2 Decolonising conflict reporting: media and election violence in Zimbabwe

TENDAI CHARI

3 Conspicuous and performative blackness as decolonial political branding against the myth of the post-colonial society:

a case of the EFF

ROFHIWA FELICIA MUKHUDWANA

\section{PART II}

Film and photography as activism: decolonisation and performance

4 Zanele Muholi's work as decolonisation and political communication 


\section{viii Contents}

5 Documentary film as political communication in post-apartheid South Africa: Miners Shot Down

PIER PAOLO FRASSINELLI

6 Remembering and memorising: the efficacy of photography in political communication in postcolonial Africa

GEORGE NYABUGA

7 "Killing with kindness": political icons, socio-cultural victims: visual coloniality of the Siddis of Karnataka, India SAYAN DEY

8 On the question of decolonisation, gender and political communication

SALLY OSEI-APPIAH

\section{PART III}

Music, radio and social media as politicised "spaces"

9 Freedom in the jazz imaginary: twentieth-century aesthetic revolt SALIM WASHINGTON

10 Empowering communities through liberalisation of airwaves in Ghana

AFRICANUS L. DIEDONG

11 In the realm of uncertainty: Kenya's Ghetto radio as politicised space

WILSON UGANGU

12 Social media as a sphere of political disruption 


\section{PART IV}

The media, the digital public sphere, and decoloniality

13 Transformation, fragmentation and decolonisation: the contested role of the media in postcolonial South Africa

YLVA RODNY-GUMEDE

14 The voice of the voiceless? Decoloniality and online radical discourses in South Africa

LORENZO DALVIT

Index 

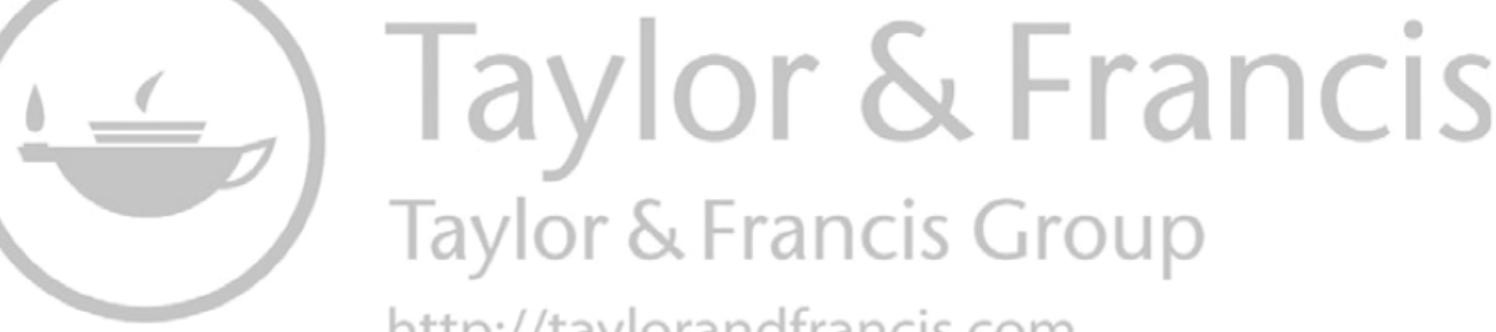

http://taylorandfrancis.com 


\section{Figures}

7.1 Political icons, socio-cultural victims 92

7.2 Indians of African origin 92

7.3 Hardworking Siddi woman 93

7.4 Ramzamma laughs when she is asked if she is pregnant with
her first child

7.5 Indians of African descent 100

$\begin{array}{ll}\text { 7.6 A beautiful Siddi woman } & 100\end{array}$

7.7 Siddi in India 101

7.8 Siddi boy with a painted face playing the Ngoma drum 104 

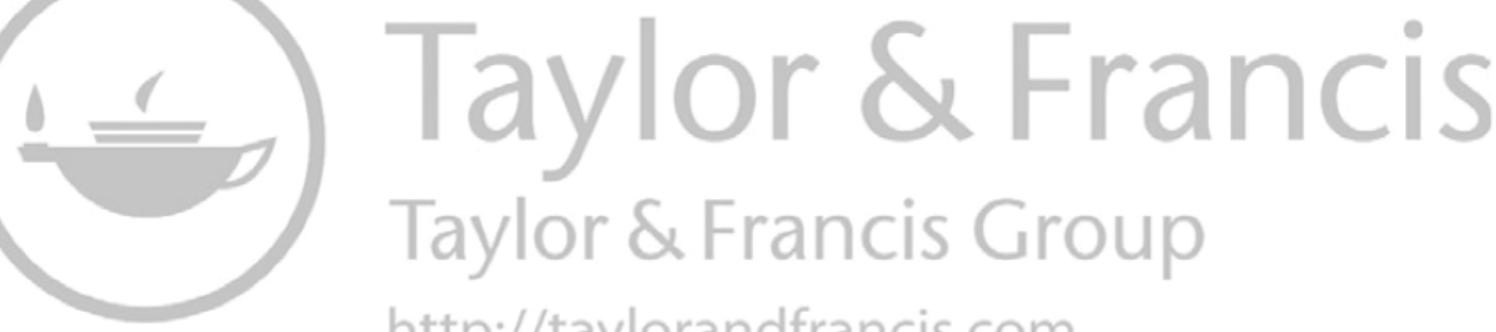

http://taylorandfrancis.com 


\section{Tables}

3.1 Analytical questions 38

12.1 Broader categories of Mawarire's disruption 184 

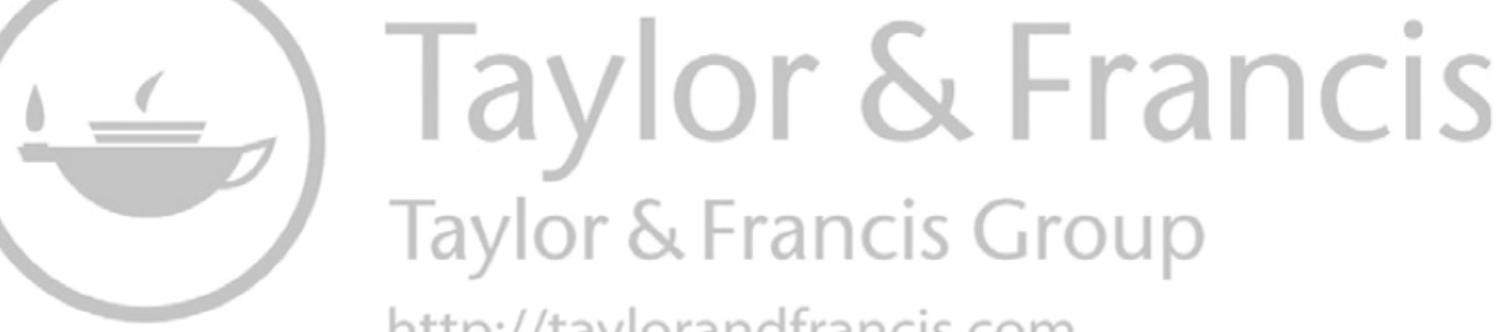

http://taylorandfrancis.com 


\section{Notes on contributors}

Tendai Chari is a Media Studies Lecturer in the Media Studies Department at the University of Venda, South Africa. Previously, he lectured at the University of Zimbabwe where he coordinated the Media Programme, and at the Zimbabwe Open University and the National University of Science and Technology (NUST) (Zimbabwe). His research interests are Political Communication, Media Representation, Media Ethics, New Media, and Media, Democracy and Democracy. His publications have appeared in the Journal of African Media Studies (JAMS), African Identities, Ecquid-Novi: African Journalism Studies, and Communicatio: South African Journal for Communication Theory Research.

Colin Chasi is Director, Unit for Institutional Change and Social Justice, University of the Free State, South Africa. He works on various aspects of the philosophy of communication. He is currently occupied in the development of what has been called participation studies - an attempt at presenting a quintessentially African approach to the field. This work follows from his efforts to put forward an existential approach to HIV/ AIDS communication. He is rated as a nationally recognised researcher (C3) by the National Research Foundation of South Africa. Colin has supervised in areas of health communication, political communication, and participatory communication. He continues to be interested in a range of areas that involve the thinking and rethinking of key conceptual underpinnings in the fields of communication.

Lorenzo Dalvit is the Head of ICT Education at Rhodes University in Grahamstown, South Africa. Until recently, he was the MTN Chair of Media and Mobile Communication in the Rhodes School of Journalism and Media Studies. His areas of academic interest include issues of power and social justice in relation to ICT, digital communication theory, ICT for development, mobile services, and localisation in African languages. $\mathrm{He}$ has co-authored over 100 publications and has supervised more than 30 students across various disciplines (Media Studies, Education, African Languages, and Computer Science). He is involved in various ICT-fordevelopment initiatives and international collaborations. 
Sayan Dey grew up in Kolkata, West Bengal. He completed BA (English), MA (English), and PhD (English) from Banaras Hindu University, Varanasi, and is currently working as Lecturer at Yonphula Centenary College, Royal University of Bhutan. Before joining there, he worked as an Assistant Professor at Amity Law School, Noida and as a Lecturer at the Faculty of Humanities, Royal Thimphu College, Bhutan. As a contributor and editor, his publications appear in different edited books, journals, blogs, and tabloids. With respect to his research on decoloniality, he has been awarded several international conference and project grants: German Research Foundation Conference Grant (2016 and 2017), Charles Wallace India Trust Fellowship (2017), GAPS Travel Grant (2018), Journal of International Women's Studies Fellowship (2018 and 2019), and Volkswagen Foundation Scholarship (2019). Besides these, he is a research documentary film maker. His first documentary "Their Stories, Their Voices: The Orphans of the British Raj" has been screened in several film festivals and academic forums across the world. He is one of the founding members of "Aurthaat Productions: A Creative Research and Academic Archive" which preserves stories and documents associated with unique histories, cultures, and traditions across the world. The link to the website is https://www.aurthatproductions.com/. Apart from Aurthaat Archives, he has also recently initiated a podcast series on "Everyday Decoloniality: A Multicultural Initiative" in collaboration with The Indian Hour Tabloid (https://www.youtube.com/channel/ UCENrAt-FdVZN4Pn6gmXZ4Lw). The central purpose of the project is to reach individuals beyond the academia. His areas of academic and research interests are decolonial studies, postcolonial studies, racial studies, cultural studies, social anthropology, food humanities, and modern Indian theatre.

Africanus Lewil Diedong is the Editorial Chair of the Ghana Journal of Development Studies. He holds a PhD in Social Communication from the Gregorian University, Rome. He is a Lecturer in the Department of African Studies, Faculty of Integrated Development Studies, University for Development Studies.

Pier Paolo Frassinelli is an Associate Professor, who has lived in Italy, England, Ireland and, since 2003, in South Africa, where he first came to take up a position as Andrew W. Mellon postdoctoral fellow at the University of the Witwatersrand. Along the way, he has developed research and teaching interests that cut across traditional disciplinary boundaries. They span critical theory, postcolonial and decolonial studies, translation, African cinema and culture, communication, and the common. Among his edited and co-edited volumes are Traversing Transnationalism: The Horizons of Literary and Cultural Studies and Dossier: South Africa, a special issue of the US journal Mediations. He has recently published in, among others, Critical Arts, Journal of African Cultural Studies, 
Studi Culturali, CLCWeb: Comparative Literature and Culture, Social Scientist, and Journal of Postcolonial Writing.

Beschara Karam is a Professor of Media Studies at the University of South Africa and teaches political communication and film studies. Beschara co-wrote the White Paper on Film in 1996, which served as the basis for the conceptualisation and implementation for the South African National Film and Video Foundation. She has published on political communication, film and decolonisation, censorship and film, representation and the media, gender and the media, trauma, counter-memory, postmemory, Afrofuturism, Black Panther, and the artist, William Kentridge. Beschara is on the editorial board of the accredited journal, Image \& Text. She is the co-founder of the community engagement project Landscapes of Cinema: Hearing our Voices, Screening our Cultures, which screens and presents seminars about African trauma, memory, postcolonialism, and decolonisation. Beschara was an anti-apartheid activist in Imbali, and its surroundings, at the height of the state of emergency, in the middle of the civil war in then Natal. She also wrote and introduced the first South African undergraduate political communication module in 2001 .

Trust Matsilele is an academic, journalist, analyst, and political consultant with over ten years' experience in media, civil society, academia, and party politics. He started his career at Zimbabwe's national broadcaster in 2004 as a producer cum presenter. He later worked for a number of entities for varying periods: The Zimbabwean newspaper, Kaya FM, ARD Radio, Radio VOP, National Constitutional Assembly, CNBC Africa, Forbes Africa magazine. During these stints, he worked as a political and business journalist covering stock markets, investment summits, and regional political gatherings like the SADC and AU summits. Educationally, Matsilele's highest qualification is a $\mathrm{PhD}$ in Communication Studies from the University of Johannesburg which he obtained in 2019. He holds a Masters' of Philosophy Journalism from Stellenbosch, BA Honours from the University of the Witwatersrand, and a Diploma in Journalism and Communications from CCOSA in Zimbabwe. He has a wide knowledge of politics in Africa generally and South Africa, Zimbabwe, Malawi, Kenya, and Senegal in particular where he worked actively for democracy and political entities. He is currently a lecturer with the Cape Peninsula University of Technology.

Rofhiwa Felicia Mukhudwana is a senior lecturer in the Department of Communication Science, University of South Africa. She is an academic who has worked with Wits, University of Johannesburg, and University of Pretoria. She is a corporate communication professional, a government communication researcher, a reader of International Relations, Foreign Affairs, and a scholar of Media Studies. Rofhiwa envisages being 
involved in the professional world wherein analytical, problem-solving, and communication skills are utilised for the best possible results. Some of her research interests include strategic communication, effectiveness and excellence in communication management, communication evaluations, stakeholder management, crisis communication and crisis management, media relations and media evaluations.

Bruce Mutsvairo is a professor of journalism at Auburn University. He studies the socio-political significance of journalism and social media as potential harbingers of democratisation, particularly in the Global South. He spent five years reporting for the Associated Press in the news agency's Amsterdam, Netherlands bureau. Previously, he served as an associate professor in journalism at the University of Technology Sydney, Australia, and an assistant professor in digital journalism at Leiden University's Liberal Arts Program in the Hague, the Netherlands. He also spent three years as a member of the journalism faculty at Northumbria University in England, where he directed the MA in Mass Communications. While completing his $\mathrm{PhD}$, he was a teaching assistant at Emerson College's Study Abroad Program in the Netherlands. He has delivered keynote addresses at major conferences in several countries, including Norway, Germany, the Netherlands, Nigeria, Kenya, and Zimbabwe. He has been a visiting scholar at the University of Mississippi (2012), Wageningen University in the Netherlands (2017), and the University of the Witwatersrand in South Africa (2016). An author or editor of eight scholarly books (Amsterdam University Press, 2019) (Palgrave Macmillan, 2020, 2018a, 2018b, 2016a, 2016b) and Rowman \& Littlefield (2019, 2018), Bruce is the founding editor of Palgrave Studies in Journalism and the Global South, a Palgrave Macmillan book series (co-edited with Saba Bebawi and Eddy Borges-Rey). He also serves on several editorial journal boards including Digital Journalism, Journal of Applied Journalism and Media Studies, and African Journalism Studies. His research has appeared in leading peer-reviewed journals including among several others Digital Journalism, Journalism and Mass Communication Educator, Media, Culture and Society, Information, Communication and Society, African Journalism Studies, and Westminster Papers in Communication and Culture.

George Nyabuga is a senior lecturer in the School of Journalism and Mass Communication at the University of Nairobi. He holds a PhD in Politics, History, and Media from Coventry University. His interests include Kenyan, African, and world politics; how various actors (governments, civil society, and ordinary citizens) can enhance their use of media and journalism; and the impact of information and communication on society. $\mathrm{He}$ also has nine years of practical experience in journalism at various newspapers in Kenya, South Africa, and the USA. He has worked as a managing editor, reporter, correspondent, and sub-editor. 
Sally Osei-Appiah is a Teaching Fellow at the School of Media and Communication, University of Leeds. Her research expertise is in political communication, gendered mediation, digital campaigning, African media and politics, democracy, and visual communication. She has published for both academic and non-academic audiences including in African Journalism Studies, Political Communication and Covid-19: Governance and Rhetoric in Times of Crisis, UK Election Analysis 2019: Media, Voters and the Campaign, and The Conversation. Sally has also been involved with several public engagement events where she has shared her expert knowledge on women in politics, gender inequality, democracy, and sustainable development goals in Africa. She is Reviews Editor for the journal Information, Communication \& Society.

Ylva Rodny-Gumede is the Head of the Division for Internationalisation and a Professor in the School of Communication at the University of Johannesburg. She is also a Senior Associate Researcher with the Stanhope Centre for International Communications Policy Research at the London School of Economics. She holds a PhD from the School of Oriental and African Studies (SOAS), London University as well as an MA degree in Politics from the University of the Witwatersrand in South Africa and an MA in Journalism from Cardiff University in the UK. Ylva is a former journalist with experience from both print and broadcast media. Her current research focus is on communication and transformation and innovation of the discipline. Ylva is rated as a nationally recognised researcher by the National Research Foundation of South Africa.

Wilson Ugangu is currently Senior Lecturer of media studies at Multimedia University of Kenya, where he also holds the administrative position of Associate Dean, Faculty of Media \& Communication Studies. He has written and researched extensively on Kenya's and Africa's media and attendant issues of policy, democracy and participation, training and research. His research focus includes media and communication policy in developing societies, media and culture, international communication, comparative media studies, and media theory. Dr Ugangu has undertaken various consultancies in the broad area of communication for various organisations such as UNESCO, UNIFEM, IDRC, ASARECA, Friedrich Ebert Foundation, and the Media Council of Kenya among others. He has received personal IIE grants from the Ford Foundation to research various issues, including studying media trends in Kenya and Uganda and an assessment of media reportage of Kenya's elections in 2013. In 2012, Dr Ugangu led an initiative for the Climate Change Agriculture and Food Security programme (CCAFS) that utilised local language radio as a tool for enhancing knowledge and dialogue in communities coping with climate change. Dr Ugangu received the Doctor of Literature and Philosophy degree in communication science (D. Litt \& Phil) at the University of South Africa in 2013. 


\section{$\mathrm{xx} \quad$ Notes on contributors}

Salim Washington is a composer and multi-instrumentalist, playing tenor sax, flute, oboe, and bass clarinet. He has played and recorded with many of the luminaries of the art form and has been featured in festivals and other venues throughout the USA, Europe, Africa, Latin America, and Asia. Washington has combined a life in music with a life of the mind, and is a scholar of Black music and culture, having written several articles and co-written with Farah Jasmine Griffin a book about the collaboration between Miles Davis and John Coltrane. He currently serves as professor of music in Durban, South Africa, teaching jazz and mentoring young musicians at the University of KwaZulu-Natal. He works to combine his artistry and pedagogy with his political conviction that we must work to improve our society with greater justice for all. 


\section{Acknowledgements}

We would like to thank the unsung heroes of this project, our external reviewers, without which this project would not have been possible:

Professor Anthea Garman, University of Rhodes

Professor Tendayi Sithole, University of South Africa

Dr Kelvin Chikonzo, University of Zimbabwe

Dr Monica Chibita, Uganda Christian University

Dr Oswelled Ureke, University of Johannesburg

Dr Priscilla Boshoff, University of Rhodes

Dr Ronesh Dhawraj, South African Broadcaster Corporation (SABC)

Dr Shenid Bhayroo, Saint Joseph's University in Philadelphia

Dr Ufuoma Akpojivi, University of the Witwatersrand

Mr Leshaba "Tony" Lechaba, University of South Africa

Mr Melusi Mntungwa, University of South Africa

Mr Simphiwe Rens, University of South Africa.

We would also like to thank the publisher, Routledge, as well as editors Leanne Hinves, Helena Hurd, and Henry Strang. With a huge shout out to Matthew Shobbrook for his passion and verve. 

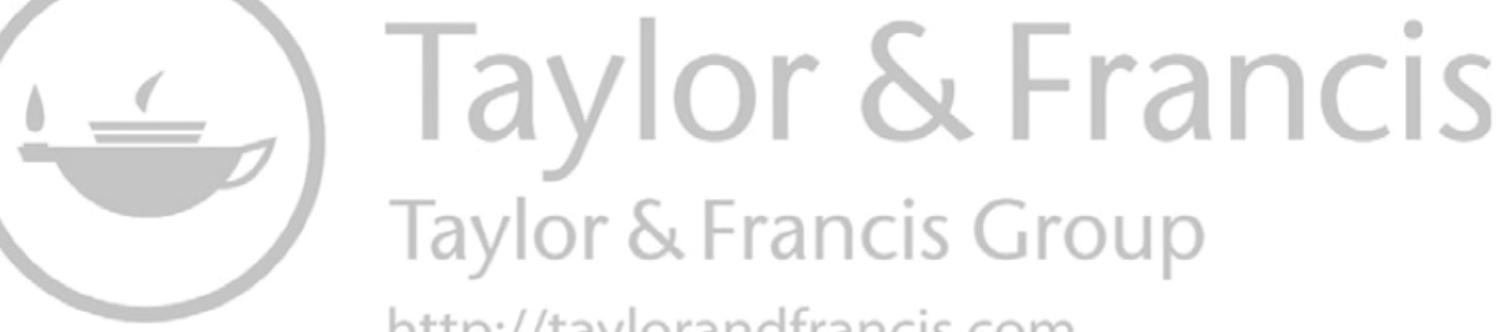

http://taylorandfrancis.com 


\title{
Foreword
}

\section{Political communication for upending colonialism and its legacies}

\author{
Colin Chasi
}

If politics is, as Harold Lasswell (1936) famously said, a set of practices that informs who gets what, when, and how, then political communication is an important art. For political communication will then say something about how the craft of distributing social goods is recognised, expressed, discussed, and deliberated about with consequences for how commonwealths are created. Political communication is hence of importance for those who are interested in upending the colonialism and its legacies, replacing these with more emancipatory orders.

Depending on how a population recognises its realities, and on how it uses communication to express differing views about how the commonwealth should be formed, politics can be emancipatory or oppressive.

For Giddens (1991: 210), emancipatory politics is about "liberating individuals and groups from constraints which adversely affect their life chances."

Emancipation means that collective life is organised in such a way that the individual is capable - in some sense or another-of free and independent action in the environments of her social life. Freedom and responsibility here stand in some kind of balance. The individual is liberated from constraints placed on her behaviour as a result of exploitative, unequal, or oppressive conditions, but she is not thereby rendered free in any absolute sense. Freedom presumes acting responsibly in relation to others and recognising that collective obligations are involved (Giddens, 1991: 213).

Politics that is emancipatory promotes freedom of choice. It produces an existence that is free of oppression. "In the context of a social existence free of oppression, alienation and immiseration, the striving for identity could become an exuberant expression of the joy of existence in a liberated life that is an open field of possibilities" (Zack, 1997: 106).

Colonial heritages are oppressive in part because they stand against people claiming sovereignty over their situations. Being subjected to colonised ways of seeing and acting people, fail to see the unjust reality that their situations strongly merit to be fought and overcome. By seeing the world through colonial languages and logics, the oppressed become parties to their own oppression. 
The history of anticolonial struggles is marked by efforts to enable the oppressed to engage in emancipatory politics. This history is a history of interventions that has been described as Black Radical Politics, which draws on influences of Marxian thought and experiences that grew out of the history of African peoples' fights against European domination in search of civil rights, national liberation, Black power, selfdetermination, or in antiapartheid struggle (see Modiri, 2017). This rich history includes struggles against slavery by people of African descent in the Americas and beyond. It includes the expressions of the Negritude movement, which emerged in the 1930s and 1940s to assert pride in Black identity as a way to enable blacks to fight against the oppressions that black people experience globally on account of slavery, colonialism, and apartheid. It also includes the work of the Black Consciousness Movement that emerged in South African in the mid-1960s to fight against apartheid — which it saw as an extension of colonial domination.

Black Consciousness is concerned with the political disinheritance of Blacks. Drawing on histories of Black thought, including the work of Franz Fanon and Paulo Freire, it calls upon Black people to regain the agency needed to fight against colonial oppression. It thus calls upon the oppressed, to engage in the "game of power politics" by building strong institutional foundations, "to rise and attain the envisaged self" (Biko, 1987: 68).

The "envisaged self" that Biko speaks of is a self that can only materialise in a society free of colonial and apartheid oppression. It is a self that is able to act with the freedom to co-create a world in which it and others jointly enjoy dignity and worth.

"The envisioned self" was Biko's futuristic concept by which he called for more than just the recovery of a human essence dismembered, distorted, disoriented, oppressed, but also for how that essence could be recovered and remoulded under new historical circumstances spanning more than 150 years of a painful yet purposeful effort of seeking to reconstitute it into a new human being (Ndebele, 2017: x).

Biko's envisioned self is a social self. Its possibilities of freedom are tied to the freedoms of others on the premise that "we cannot be conscious of ourselves and yet remain in bondage. We want to attain the envisioned self which is a free self" (Biko, 1987: 49).

What is at stake in the emancipatory politics that Biko and others of the Black Radical Tradition have articulated is the possibility of moving towards decolonial futures under which people can work together to flourish rather than to oppress one another. This is to imagine, as Gulick (1965: 8) prognosticated in a different context, a realm within which social instincts can lead to humans

1 acting in with freedom and choice;

2 evolving a productive culture of communicative cooperation; 
3 creating a theories of how life should be lived that conduce to the production of better worlds; and

4 using both individual and communal memories to communicatively to make promote more just social arrangements.

Gulick says this in the context of his "departmentalisation theory" which idealises the possibility of coordinated behaviour in "self-contained" organisational units (March \& Simon, 1965: 28). For current purposes, this is important. For it is important to see that political communication must go beyond thinking merely about those modes of communication that are ascribed to actors in legitimated political theatres. We must see that politics is for everyone and that all communication is political. After all, communication designates what matters and how it matters with consequences for how freedom and oppression are distributed - to whom, when, and how.

Because of the heightened sense of importance that arises from how pandemics rupture logics of existence (Singer, 1990: 119), we can also see more acutely how all communication is political (at least in the sense that it says something about who gets what, from whom and when).

In the midst of the COVID-19 epidemic, one sees with heightened clarity, the capacity of communication to lend meanings to realities and to inform how people live their practical lives. Simply observe how declarations of pandemic are demonstrated to be political acts. It is not the fact that there are actual risks to life that determine that a pandemic is declared. It is the political will to raise attention with regard to particular risks that allows a pandemic to be announced. What we are seeing is that political communication, in this instance of COVID-19, has consequences beyond those that which it specifically addresses. In the instance of COVID-19, which is apparently a medical predicament, the political communication that arises has significance that relates to economic, racial, and other spheres as followers of the news may discern.

The symbolic power of colonial naming can be seen, for example, in how colonial ideas to do with race have shaped geo-spacial planning in places such as South Africa. This colonial special planning has rested on racial symbolisms to designate and allocate Black people (including those called "Black Africans," "Indians," and "Coloreds") to areas that are environmentally undesirable. Thus, to be Black is often to live, in South Africa, in overcrowded southern suburbs to which daily winds blow the worst of the industrial smog that the country's industrial machinery produces. It is also to generally live on the worst pieces of agricultural land, which suffer from overgrazing and general environmental degradation.

An unmissable aspect of postcolonial struggles is unsurprisingly, then, about how the historically marginalised can get a political say in the order of things. The tragedy is that, often, those of the previously colonised who gain a seat in positions of authority, for example, in the government, in private enterprises, or in the media are often constrained to act according to 


\section{xxvi Colin Chasi}

colonial system-logics so that nothing fundamentally changes for the vast majority who continue to experience short and brutish lives.

At least two significant points need to be made here:

1 The political systems that undergird colonial and apartheid oppressions are embedded deep in the frames of how postcolonial societies were formed. In consequence, mere cosmetic changes in the faces of those who run these systems does not change the ways in which they generate inequities and injustices. It is important, if the goal is to produce more equitable societies, to identify and replace the underlying mechanisms by which injustices are produced with ones that conduce instead to justice.

2 Political communication, which is enabled by factors of the symbolic power of languages, is key to the political distribution of risks. It either enables the productive capacities of injustice to be seen and to be removed, or it enables their production and reproduction.

To reckon with the above, one is led to see that anyone who acts to decolonise, and to thereby create a system that works for everyone in ways that are just, must be prepared to bring down certain parts of the ways in which the "system works". Here, the problem is that colonialism works for some against others in ways that are unjust.

Meanwhile, it is difficult to know which aspects of colonial systems to attack - for these systems are so complex that one cannot be sure that upending even one element does not lead to greater harms. The hands of politicians whose aims are to decolonise the systems within which they operate are therefore always sallied by uncertainty. It is well known that some, such as the late President of Zimbabwe, Robert Mugabe, in the name of decolonising their societies, have persevered with policy options that are filled with immense loss and pain on the grounds that the ends of decolonisation justify the means. If it is true that political choices always yield messy and unintended consequences, particularly in complex postcolonial settings, what is evident is that the art of politics involves the wise calculation of the risks associated with each choice of action.

It is reasonable, however, to see, as Machiavelli (1925: 154) says, that

...we may conclude that those who cannot change their system when occasion requires it will no doubt continue prosperous as long as they glide with the stream of fortune; but when that turns against them they are ruined, from not being able to follow that blind goddess through all her variations.

At the same time, we can see that were those who suffer on account of histories of colonial suppression cannot escape their oppression by doing nothing. 
In postcolonial states, if the study of political communication is to go beyond blaming societies and individual leaders and followers for their failures to attain decolonial purposes, it will be wise to invest in new forms of knowledge that recognise the complexity of the task at hand. The point is not to deny individuals and societies their responsibilities for how they act in their risk contexts. It is rather, with Zwi and Cabral (1991), to speak of "risk contexts" as social determinants of behaviours. This is to recognise that risk is "so to speak, ascribed by civilization[s]" (Beck, 1992: 23), and in the way to change the profile of the risks we face is to change the civilisational logics within which we co-create our realities. This is why the study of political communication matters.

If one studies political communication within its multitudes of sources of stigmatised and degraded (cf. Schoepf, 2004: 19), then one has a fair chance to improve the courses of action or calculated risks one makes. In short, the study of political communication in its multitudes of arenas-as this book seeks to do-is an important element in producing the kinds of knowledge by which reliance on colonial epistemologies and cognitive schema can be overcome.

To be human is to live with uncertainty and to always deduce new possibilities from surrounding realities. Indeed, we humans have the remarkable capacity of finding infinite possibilities even among the most limited options. This capacity is best actuated whenever live or practicable options for agentic action are made available. By departing from existing frameworks that limit what political communication study is to what Western scholarship has laid out, this book enables its readers to think with increasing vitality about diverse contexts in which they find themselves. In this way, it lays out new grounds upon which desirable decolonial ideas and practices can be envisioned and practised.

\section{References}

Beck, U. 1992. Risk society: Towards a new modernity. Translated by Mark Ritter. London: Sage.

Biko, S. 1987. I write what I like. Oxford: Heinemann.

Giddens, A. 1991. Modernity and self-identity: Self and society in the late modern age. Stanford, CA: Stanford University.

Gulick, L. 1965. Management is a science. Academy of Management Journal, 8:7-14, Mar.

Lasswell, H.D. 1936. Politics; who gets what, when, how. New York: Whittlesey House, McGraw-Hill Book Co.

Machiavelli, N. 1925. The prince. London: Philip Allan \& Co.

March, J.G. \& Simon, H. 1965. Organizations. New York: Wiley.

Modiri, J. 2017. The jurisprudence of Steve Biko: A study in race, law and power in the "afterlife" of colonial-apartheid. Unpublished thesis: University of Pretoria.

Ndebele, N.S. 2017. Foreword: 'The envisioned self'. In I write what I like. Edited by Biko, S. Johannesburg: Picador Africa, pp. vii-xiv. 


\section{xxviii Colin Chasi}

Schoepf, B.G. 2004. AIDS, history, and struggles over meaning. In HIV and AIDS in Africa: Beyond epidemiology. Edited by Kalipeni E., Craddock S., Oppong J.R. \& Ghosh J. Oxford: Blackwell, pp. 15-28.

Singer, L. 1990. Erotic welfare: Sexual theory in the age of the pandemic. Edited by Butler, J. \& MacGrogan, M. New York: Routledge, Chapman and Hall.

Zack, N. 1997. Race, life, death, identity, tragedy, and good faith. In Existence in black: An anthology of black existential philosophy. Edited by Gordon, L.R. New York and London: Routledge, pp. 99-111.

Zwi, A.B. \& Cabral, A.J.R. 1991. Identifying "high risk situations" for preventing AIDS. British Medical Journal, 303:1527-1529. 14 Dec. 


\title{
1 Reframing African ontologies in the era of decolonisation
}

\author{
Beschara Karam and Bruce Mutsvairo
}

The central aim of this book is to "decolonise" political communication. However, considering the complexities of the sub-field, as well as the fact that it is a theory-praxis, it is almost a near impossible claim. With regard to the complexities of political communication, we refer to how the subdiscipline (which falls within the more established field of Communication Studies) is made up of several, often dissenting, fields, such as Organisational Communication (consider, for instance, branding, institutional communication, advertising, and public relations, to mention but a few), International Communication, Government Communication, Media Studies, and Politics. With regard to the theory-praxis, it deals not only with theories such as agenda-setting, social semiotics, and framing - but also with practical skills - such as how to write a press statement, or media report - and the skills involved in being a spokesperson or speechwriter. All of which are taught within the triad of the media, politics, and citizenry that make up "political communication"; and all of which function in democratic societies. These societies privilege the west and Europe as the centre of this democracy, which in turn has capitalism as its foundation, all of which need to be unpacked and critiqued. This is a monumental undertaking for only one book, most especially because this collaborative volume is the very first scholarly work to embark on such a responsibility. Instead, we would like to present this work as a form of "problematising" the sub-field of political communication, and, as a form of "consciousness raising", about the need to decolonise this inter-disciplinary theory-praxis. Both terms are borrowed from Paulo Freire (1970), who was a ground-breaking scholar in the Latin American liberation movement. Both of his terms are understood to incorporate: self-reflexivity, theory, and action. All of which could contribute toward liberation from oppression, social change, and social justice. For Freire (1970), critical consciousness or "conscientization" (conscientização) is the noting/uncovering of social and political contradictions and acting against oppression. But not only theoretically, but also with regard to praxis, a praxis that transforms the world into something liberatory and fights oppression with regard to "problematising", it is the means by which critical engagement and "dialogue" attempt to destabilise the power relations that

DOI: $10.4324 / 9781003111962-1$ 
relate to class, gender, identity, and race (Freire 1970). This book begins the process of dialogue and self-reflexivity by interrogating the theory-practice of political communication, thereby beginning the process of creating new knowledge production about political communication in Africa. The contributing authors have done this either by using a decolonial lens, or by using decolonial research methods. We - like the seminal authors Walter Mignolo (1995, 2000), Ramón Grosfoguel (2007, 2011), Enrique Dussel (1977), Aníbal Quijano (1991, 2000), and Nelson Maldonado-Torres (2007) realise that such a decolonisation of political communication and the resultant knowledge creation need to consider the epistemic insights of authors from Africa, in the field of political communication. In other words, African authors and scholars thinking with, and from, 'subalternalized racial/ ethnic/sexual spaces and bodies' (Grosfoguel 2011:2; cf. Grosfoguel 2007). Or, put another way, it should be an example of what Archie Mafeje (2000) has called "endogeneity" - that is, African representation/scholarship that affirms African socio-economic context, positionalities, experience/s, African subjectivities and insights, and knowledge from Africa; and, in doing so, centres Africa, removing it from the margins. This edited edition is also what Grosfoguel refers to as "epistemic disobedience" in that, instead of supporting the current status quo in political communication, it serves to challenge, disrupt, destabilise, and interrogate this status quo, which, without doubt, is racialised, hierarchical, classist, capitalist, heteropatriarchal, gentrified, imperialist, and westernised. As such, it also serves to work as an agent of change by questioning post-colonialism, or, as Ndlovu-Gatsheni has argued, the 'myth of post-colonialism' (2013). In other words, it cannot be post-colonial if the "colonial matrix" still exists and continues to "entangle" us (Ndlovu-Gatsheni 2013).

Decolonisation continues to evolve. For those of us in the Global South, it is a continuous journey, perhaps a never-ending one. It is a right that should be accorded so as to preserve Indigenous intellectualism and understand the importance of intellectual freedom. It is a movement forming the basis for the preservation, defence, and promotion of home-made ideas and ways of thinking. The brutal subjugation of Indigenous peoples has had an extremely distressing impact on the colonised populations. These range from the exploitation and appropriation of their customs and cultures to endless ethnic rivalries and environmental challenges. When studying political communication, based on the available literature, we are again looking at the field that historically has largely been conceptualised from a western-centric perspective, which itself is not entirely problematic but becomes particularly objectionable when other ontologies and experiences from other regions are considered less important and unwelcome in the public discourse. For example, as argued by Bouterse and Sengupta (2018:6), it is important that alternative, non-digital sources of knowledge are equally respected because 'public knowledge online - as exemplified by Wikipedia, the fifth most-visited website in the world - is written primarily by white 
men from Europe and North America'. Those in Global South need to be content owners and content producers because being consumers of content produced in the west is no longer good enough as it leaves them relying on western ways of thinking. Africa should produce its own theories and shy away from being used as a platform to test Eurocentric ideas (Moyo 2020). The fact that some Africans may have no access to capital does not mean they have no capacity to produce their own knowledge. Political communication should be decolonised as to show the real challenges that African people, both politicians and voters, face in their quest for inclusivity. Not everyone in Africa has access to free Internet - data costs are beyond the reach of many Africans yet the political communication-related content produced in the west tends to assume that the Internet is changing political dynamics in Africa. But decolonising anything is no easy task. Decolonisation is, by nature, a complex concept. It needs to be carefully negotiated because partnership with the people who have historically benefited from coloniality is oftentimes necessary in order for it to be successful. We see the need for decolonisation but we are also cautious about unnecessary radicalisation.

As such, chapters in this book are all localised, situated, and contextbound: Africa is situated centrally, epistemologically; and most significantly, the marginalised are presented with enunciation from the subject/ subaltern or previously othered voices. It is important to note, however, that writing from and about the South or in this case Africa does not by definition make the research or knowledge creation de facto subaltern or decolonised. Neither are such scholarly contributions necessarily critical of the embedded and insidious power relations. Past scholarship has, in fact, often been merely descriptive, using African case studies, or quantitative research about politics in Africa, and therefore falls short of a decolonial critique by not interrogating the innate power relations, whether they be gendered, classist, capitalist, or racist (Olukotun \& Omotoso 2017). Because of this, the call for chapters was very specific, and we, as co-editors, would only consider chapters that are from, and about, decolonisation and political communication. That is, the book was agenda-driven: the chapters had to contribute in some way to problematising and/or decolonising political communication. By prefacing a decolonial lens or episteme, it therefore serves to challenge political communication research, which generally has its focus on empirical, quantifiable, and western knowledge (Mignolo 2011:202; cf. Thatelo 2017; Lechaba 2019). The decolonial lens, or episteme, also serves to make scholars aware of what Lewis Gordon (2000) has termed "constitutive blindness". In other words, we take it for granted that western methods of research are the only acceptable types of research. What needs to be acknowledged, therefore, is that research methods and scholarships in political communication are also historically situated or positioned through the colonisation of knowledge. In contesting this "constitutive blindness" (Gordon 2011), these chapters, or knowledge production, had to 
be articulated from beyond the othered colonial "border" line and, by doing so, take the "points of view of those whose very existence is questioned and produced as insignificant' (Maldonado-Torres 2007:262).

Nelson Maldonado-Torres, in 2006, termed the quest for decolonisation, the "decolonial turn". He, along with authors such as Walter Mignolo (2011) and Ramón Grosfoguel (2007), called for the epistemic (knowledge) decolonial turn - or as Grosfoguel stated, the call to 'epistemologically transcend, decolonize the Western canon and epistemology' (2007:211). Similarly, Archie Mafeje called for a "combative methodology" or a "combative ontology" (2000), and Walter Mignolo called for an "epistemic disobedience" (2011). In decolonising political communication, this book therefore intends to contest the "colonial power matrix" that makes up the discipline-practice (Quijano 1991, 2000) which, to reiterate, includes reified gender hierarchies, international and local racialised divisions of labour and class, aesthetic hierarchies, and epistemic hierarchies that preface, or privilege, the west over the rest. Quijano also states that his concept is an "organising principle" involving domination and exploitation and is intrinsic socio-culturally, politically, institutionally, and epistemologically (Quijano 1991, 2000). This "organising principle" is also intrinsic to political communication. Similarly, it is also, as Walter Mignolo suggests, 'a complex conceptual structure that [has] guided actions in the domain of economy (exploitation of labor and appropriation of land/natural resources), authority (government, military forces), gender/sexuality and knowledge subjectivity' (2000:19). This "colonial power matrix" ("patron de poder colonial") or "coloniality of power" (cf. Mignolo 2000) is inherent in political communication. This book intends to contest this "colonial power matrix" by providing a decolonial critique that privileges knowledge from the silenced and subalternised and transcends the western political communication canon by questioning the colonial organising "principle" that is embedded and infiltrates political communication at every level. In order to understand to what extent these hierarchical principles, organised around exploitation and domination, are "entangled", to borrow another term from Grosfoguel $(2007,2011)$ within political communication, we need to briefly "unpack" or scrutinise the discipline and practice itself.

\section{Political communication: theory-practice}

Brian McNair defines political communication as "purposeful communication about politics", which comprises of political actors (including the media, politicians, and pressure groups), political organisations (party and non-party), and the audience or citizenry (2018:4-5). All of which, in an ideal democratic society, plays out in Jürgen Habermas' public sphere (1995). As a discipline, political communication is an embryonic subject (and features as a sub-discipline) in African university curricula and appears intermittently under Communication or Communication Studies/Science and is mostly 
inter-disciplinary (cf. Olukotun \& Omotoso 2017; Mutsvairo \& Karam 2018). It is very often a misunderstood field, with many scholars and practitioners assuming that this is a study of politics proper. That is definitely not the case though. What is also apparent is that the discipline itself has cannibalised and originated from some of the more established western disciplines of organisational and corporate communication (advertising, public relations, image management, and informational management) - as well as from media studies (cultural and media studies, such as Stuart Hall's social semiotics and audience reception studies; as well as journalism), from political philosophy (such as rhetoric; cf. Edwards 2009), and from political science studies (McNair 2018). In addition to these cannibalistic components, political communication is two distinct "things": theory-practice. All of these threads or links are "entangled" and have several commonalities: they are capitalist, colonial, imperialist, and western. In a sense, this triad of politics, media, and citizenry belies its racist, classist, gentrification, hierarchical, imperialist, and heteropatriarchal western roots, as the theory-practice claims to be about democracies - and about how this triad "works" within these democracies, or "fails" in non-democracies. It sets western democracy and hegemony, along with the western preference for "scientific" research, as its benchmarks. This book therefore offers new knowledge that transcends the "Western Code" which has served "not all humanity, but only a small portion of it that benefits from the belief that is terms of epistemology there is only one game in town' (Mignolo 2011:xii).

\section{Conceptualisation of the book}

In 2018 we published an edited volume, with Palgrave Macmillan, focusing on political communication, entitled Perspectives of Political Communication in Southern Africa (Mutsvairo \& Karam 2018). The volume included authors from Africa, who wrote about African politics and the different forms of political communication. It was the first book published to write from, and about, African political communication. Despite being a cutting-edge book, and the first of its kind, it soon became apparent that the colonial matrices were still embedded in the theory-practice research; and further enquiry was needed in order to keep up with the decolonial turn.

This newly proposed book is the research that was needed to start the self-reflexive enquiry, problematisation, the disentanglement, and, most significantly, the foray into decolonising political communication, thereby encouraging a dialogue for other scholars and practitioners to do the same. It is important to note that our call is not to delegitimise western scholarship on performance and political communication. Ours is a call for inclusion. All sources of knowledge are important (Moyo \& Mutsvairo 2018). In similar vein, African knowledge should be acknowledged. We don't want to foist it on anyone, but we think it is imperative for African scholars to have an opportunity to tell their stories. However, when African scholarship is rejected, we 
should also be ready to accept that reality. We cannot fight years of endless racism and neglect with another form of bigotry. Decolonisation needs a dialogue more than anything else. In this book, we retheorise political communication and performance in the age of decolonisation, offering conceptual directions on how the field is taking shape in an era where new voices seeking inclusion and diversity of how it should be theorised continue to emerge.

\section{Chapters' overview}

The book is divided into four sections, all of which deal with media (from film to music), as well as forms of political communication, decolonisation, and performance. The very first chapter, after the introduction, Chapter 2, written by Tendai Chari, focuses on journalism and media reporting during electoral periods, and the challenge of decolonising conflict reporting in Africa (most specifically Zimbabwe). Rofhiwa Felicia Mukhudwana follows that chapter (Chapter 3) by focusing on what she terms 'conspicuous and performative blackness as decolonial political branding' with a case study on a left-wing opposition party, the Economic Freedom Fighters (Pan-Africanist). Chapter 4, written by Beschara Karam, focuses on the work of Zanele Muholi, most specifically her film, Difficult Love (Goldsmid \& Muholi 2010). That chapter is followed by Pier Paolo Frassinelli's research (Chapter 5), which argues for documentary film as political communication in post-apartheid South Africa. He focuses on several films, which he argues, seek to subvert hegemonic or state sanctioned narratives in post-apartheid. Chapter 6, written by George Nyabuga, focuses on the use of photography in political activism and resistance as forms of "remembering and memorising". Chapter 7, written by Sayan Dey, argues that the photography of the Siddis (believed to be the descendants of the Zulu people from South Africa), a community in Karnataka, is a form of visual colonialism. In this instance, the camera lens works as a colonial tool to further legitimise the marginalisation and othering of the Siddis. In Chapter 8, Sally Osei-Appiah conducts research sitting at the intersection of gender, political communication, and decolonisation in Ghana. Chapter 9 begins the section on music as disruption, political communication, and decolonisation. Here, Salim Washington writes about the "the revolutionary implications of the jazz imaginary". Chapter 10 has contributor, Africanus L. Diedong, exploring how community radio stations actually enable citizen's participation in broadcasting in Ghana using the empowerment theory. While Chapter 11, written by Wilson Ugangu, researches Kenya's "Ghetto Radio" as a "politicised space", Chapter 12 is jointly authored by Trust Matsilele and Bruce Mutsvairo, and examines social media as a sphere of political disruption in Zimbabwe's cyber sphere using \#ThisFlag digital campaign as a point of departure. Chapter 13, written by Ylva Rodny-Gumede, deals with the transformation, fragmentation, and decolonisation of the role of the media. Chapter 14, the last chapter of the book, is written by Lorenzo Dalvit, 
where he suggests that while digital media can be arguably seen as a way to revolutionise public debate, by giving "voice to the voiceless", his chapter problematises which/whose voices.

\section{Conclusion}

In concluding, the aim of this book is to function as a change agent for the theory-practice of political communication in Africa, by problematising the power matrices that are embedded within, and its over-reliance on western epistemes, that dis-members its citizenry; de-contextualises; and depositions; by privileging "numbers"/quantification; objectivity and politics as a "science". It aims to delink or disentangle the western theory-practice that dominates both the field and the discipline of political communication in Africa, and other parts of the world. We believe that these chapters which preface dialogue, consciousness raising, social justice, social and political change, cognisance of context, social agency, self-reflexivity, and the inclusion of the sub-alterns - will make an indispensable contribution to the field of political communication and the (ongoing) call for decolonisation.

\section{References}

Bouterse, S, \& Sengupta, A. 2018. Decolonising the Internet: Whose knowledge. Retrieved: https://whoseknowledge.org/wp-content/uploads/2018/11/DTI-2018Summary-Report.pdf

Dussel, E. 1977. Philosophy of Liberation. Translated by Martínez, A. and Morkovsky, C. New York: Orbis Books.

Edwards, JL. 2009. Gender and political communication in America: Rhetoric, representation, and display. Plymouth: Lexington Books.

Freire, P. 1970. The pedagogy of the oppressed. New York: Continuum.

Goldsmid, P. \& Muholi, Z. (dir). 2010. Difficult love. [Film]. Johannesburg: South African Broadcasting Corporation. The entire film can be viewed for free at: https://www.imdb.com/video/vi3128728089

Gordon, L. (2000) Existentia Africana: Understanding Africana Existential Thought. New York: Routledge.

Grosfoguel, R. 2007. The epistemic decolonial turn. Cultural Studies, 21(2-3): 211-223.

Grosfoguel, R. 2011. Decolonizing post-colonial studies and paradigms of politicaleconomy: Transmodernity, decolonial thinking and global coloniality. Transmodernity: Journal of Peripheral Cultural Produduction of the Luso-Hispanic World, 1(1): $1-38$.

Habermas J. 1995. The Theory of Communicative Action, Reason and The Rationonalization of Society, Tr.T., Mc Carthy, Cambridge: Polity Press.

Lechaba, L. 2019. Textual analysis of selected articles from "The Thinker" magazine (2010-2016). MA study. http://uir.unisa.ac.za/bitstream/handle/10500/26314/ dissertation_lechaba_lt.pdf?sequence $=1 \&$ isAllowed=y

Mafeje, A. 2000. Africanity: a combative ontology. CODESRIA Bulletin, (1):66-71

Maldonado-Torres. 2007. On the coloniality of being. CulturalStudies 21(2-3): $240-270$. 


\section{Beschara Karam and Bruce Mutsvairo}

McNair, B. 2018. An introduction to political communication. London: Palgrave.

Mignolo, W. 1995. The Darker Side of the Renaissance: Literacy, Territoriality and Colonization. Ann Arbor: Michigan University Press.

Mignolo, W. 2000. Local Histories/Global Designs: Coloniality, Subaltern Knowledges, and Border Thinking. Ceeton: Princeton University Press.

Mignolo, W. 2011. The darker side of western modernity. Global futures, decolonial options. Durham \& London: Duke University Press.

Moyo, L. 2020. The decolonial turn in media studies in Africa and the Global South. London and New York: Palgrave-McMillan.

Moyo, L, \& Mutsvairo, B. 2018. Can the subaltern think? The decolonial turn in media research in Africa. In Bruce Mutsvairo (ed), Palgrave handbook for media and communication research in a Africa. London: Palgrave Macmillan, pp. 26-40.

Mutsvairo, B, \& Karam, B. eds. 2018. Perspectives of political communication in Africa. London: Palgrave.

Quijano, A. 1991. Coloniality and modernity /rationality. Indigenous Peru, 13(29): 11-20.

Quijano, A. 2000. Coloniality of power and social classification. Journal of World-Systems Research, VI(2): 342-386.

Olukotun, A, \& Omotoso, SA. eds. 2017. Political communication in Africa. Switzerland: Springer.

Thatelo, MT. 2017. A social semiotic analysis of the verbal, non-verbal and visual rhetoric of the 2009 and 2014 African National Congress (A.N.C.) political television advertisements: a comparative qualitative content analysis study. MA study. http:// uir.unisa.ac.za/handle/10500/25218 
Part I

Decolonial research 

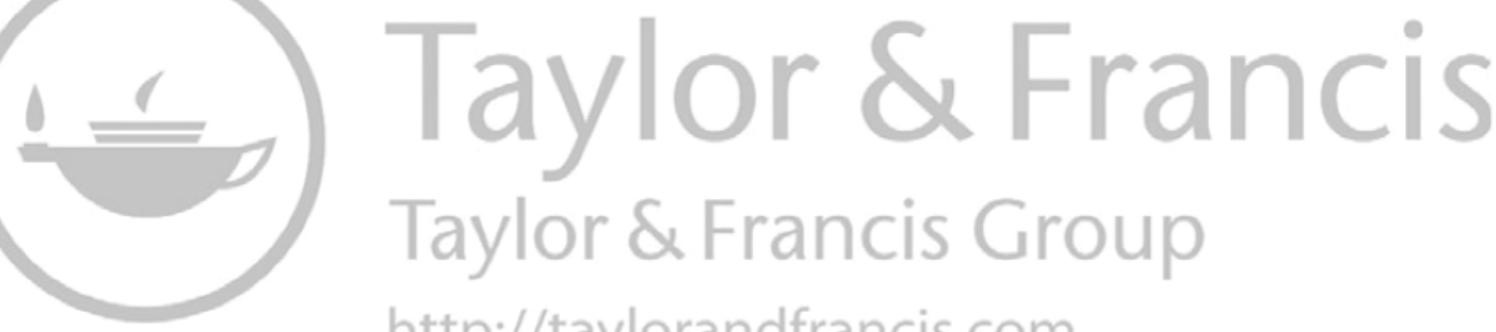

http://taylorandfrancis.com 


\title{
2 Decolonising conflict reporting \\ Media and election violence in Zimbabwe
}

\author{
Tendai Chari
}

\section{Introduction}

Violent electoral contests' postcolonial societies present quandaries for journalists. The polarising nature of violence provides a fertile ground for the reproduction and perpetuation of journalistic tropes rooted in neocolonial and hegemonic matrices of power. Combining insights from decolonial approaches and conflict-sensitive journalism theory, this chapter is a qualitative exploration of colonial practices embedded in conflict reporting in postcolonial societies. It examines structural, institutional and professional journalistic practices which predisposed Zimbabwean print media to colonial tropes in reporting election violence between 2000 and 2003.

How the media report on election violence is important because violence is a destructive force with fundamental and far-reaching humanitarian consequences. Compared to other types of political violence, election violence has received scant attention in scholarship supposedly because it is "time concentrated". Relative to wars and insurrections which take place over a relatively long time and result in huge death tolls, election violence has far fewer deaths (Meadow, 2009, p. 232). Meadow notes that except for Ivory Coast where about 3,000 people died in the 2010/2011 post-election violence and the Kenyan 2007/2008 post-election violence which resulted in the loss of about 1,000 lives, election violence has far fewer casualties (Meadow, 2009).

An interrogation of election violence reporting may provide deeper insights into the extent to which existing journalistic practices in conflict reporting subtly perpetuate coloniality in the media. This is because hegemonic and hegemonic struggles play themselves on the canvass of electoral conflicts.

Previous studies have mainly focused on the role of the media in elections, either deploying agenda setting/framing theoretical lens (Hobart, 2007), or a watchdog lens (Norris, 2000), primarily within the context of the industrialised democracies of the West. However, none of these studies have examined what Hoagland refers to as "discursive colonisation" aspects of "coloniality of knowledge" (Hoagland, 2020, p. 50) manifested in journalistic practices. 
This has left a knowledge lacuna on the extent to which conflict reporting is deeply implicated in hegemonic Anglo-Eurocentric practices where conflict is articulated through Anglo-European normative values and journalistic cannons (Hoagland, 2020). This chapter's point of departure is that media reportage of conflict, as demonstrated by the reporting of election violence in Zimbabwe after the turn of the century, is situated within the ongoing tropes of coloniality embedded in structural, institutional and professional journalistic practices. The chapter advocates for a media agenda whereby the media embrace elements of conflict-sensitive reporting anchored in Afro-centric philosophy (Kasoma, 1996) and decolonial approaches (Maldonado-Torres, 2007; Mignolo, 2007; Quijano, 2007).

Data for the study were drawn from in-depth interviews with 19 political reporters and editors of six Zimbabwean mainstream newspapers. The newspapers in question are state-owned - The Herald and The Sunday Mail - and privately owned - Daily News, News Day, The Financial Gazette and The Zimbabwe Independent. The interviews were conducted between August 2013 and October 2015 in the capital city, Harare. The selection of interview participants was guided by the need to generate thick data in relation to election violence reporting practices. Such thick data were obtained from journalists who had experience in reporting election violence in Zimbabwe and included political reporters, news editors and editors. These were accessed through referrals, thereby making the sampling strategy purposive. Interviews lasted between 30 minutes and 1 hour.

The choice of the study period was informed by the realisation that the year 2000 marked the beginning of the "Zimbabwean crisis" characterised by phenomenal electoral violence leading to loss of human life and property. Electoral campaigns took place in a tense, agitated and polarised political climate (ZESN, 2008). Such environment played host to journalistic practices which normalise Eurocentric, decontextualised narratives of conflict predicated on war journalism whereby conflict is constructed as pitting losers and winners and has no or little 'background or historical perspective' (Ting Lee, 2010, p. 320).

The rest of this chapter is divided into three parts. The first part briefly surveys literature on election violence and the media drawing insights from the work of decolonial scholars and the conflict-sensitive theory. The second part discusses institutional, structural and professional constraints faced by the media in Zimbabwe in reporting election violence, demonstrating how these are intrinsically intertwined with coloniality. The third and final part gives concluding remarks and suggests approaches alternative ways of reporting conflicts.

\section{Election violence: residual coloniality and the media}

Although election violence is a complex issue which requires nuancing, dominant narratives depict Africa as the hotbed of violence, thus evoking 
notions of residual coloniality. Reif (2011, pp. 5-6) defines election violence as "any spontaneous or organized actions" by political party candidates or their supporters, election authorities, voters or other political actors 'that employ physical harm, intimidation, blackmail, verbal abuse, violent demonstrations, psychological manipulation, or other forms of coercion... aimed at disrupting determining, hastening, delaying, reversing, or otherwise influencing an election outcome' (Reif, 2011, pp. 5-6). This definition mirrors colonial practices akin to "misanthropic skepticism" or skepticism about the "Other", whereby the relationship between citizen and subject is vertical rather than horizontal and ethics of war are suspended (MaldonadoTorres, 2007, p. 243).

Similarly, Meadow (2009, p. 234) conceives election violence as 'acts used to harm, intimidate, exploit, disrupt, hasten, delay or reverse the electoral process or outcome' and these acts happen between the voter registration process and the inauguration of a political administration. The view that election violence has both physical and psychological harm is consistent with Orientalist (Said, 1978) notions about violence in postcolonial societies where the "hyperbolic expression" of violence is genocide (MaldonadoTorres, 2007, p. 248).

A common thread running through the above definitions is the view that election violence has both physical and psychological dimensions and that it is a means to an end as its ultimate objective is to influence the electoral processes and outcomes for the benefit of the political elite, thus underscoring colonial methods of governance in the postcolonial contexts (Ylonen, 2009).

Western constructions of Africa as a "dark" and "uncivilised" continent have given rise to two dominant perspectives on the role of the media on election violence: the media either amplify election violence or act as sentinels to alert the outside world about human rights abuses. The "amplifier" perspective leans heavily on primordial accounts of election violence where media are blamed for inflaming violence through reckless and sensational reporting. Mamdani refers to this phenomenon as "the pornography of violence" whereby violence is depicted as rampant and senseless (2003, p. 141). An example is during the Kenyan 2007/2008 post-election violence where the media were blamed for 'amplifying hate speech that inflamed tensions' leading to loss of lives and property and the displacement of thousands of people (Odhiambo, 2007, p. 1).

As sentinels, the media can inform the public about the dangers and risks of participating in the election or of going to certain areas by showing people compatriots being hurt and being killed in certain places. In this instance, the media become some sort of a sentry playing a surveillance and monitoring role - alerting the public about impending danger, what some scholars have described as "burglar alarm journalism" (McQuail, 2013). Both the "amplifier" and "alarm journalism" narrative emphasise agency of the media as providers of information about election violence and defenders of human rights, thus constructing election violence as a phenomenon that 
lends itself to the logic of breaking news - the view that 'when it bleeds it leads' (Meadow, 2009, p. 232). Both approaches tend to be oriented toward "war journalism" which has been criticised for accentuating conflict rather than peace (Galtung, 2002).

Scholars argue that violence in general and election violence has great propensity to attract media attention because of its dramatic elements (Chalfont et al., 2007; Hobart, 2007; Thussu, 2009). Chalfont posits that "violence makes good copy" and is exciting to read. Obsession with drama in election violence has resulted in event-based reporting which masks the complexity of election violence. Some scholars argue that although violence is often spontaneous 'it is a product of a longer sequence of historical and political actions' (Stremlau \& Monroe, 2009, p. 5), meaning that attention on drama and conflict masks the complexities of election violence. Viewing violence as spontaneous and rampant feeds on a simplistic moral logic which harks back to colonial hegemonies whereby the world is depicted as a binary of "modern and pre-modern" (Mamdani, 2003, p. 142). Given the inadequacies of these accounts to give plausible "historical explanation of agency" in postcolonial conflicts (Mamdani, 2003), it is imperative to consider alternative theoretical frameworks which can help shed insights into the hegemonic discourses on conflict reporting normalised through news values and professional practices as media practitioners try to negotiate different obstacles in their everyday operations.

\section{Conflict-sensitive journalism: a decolonial lens}

Scholars have noted how the mass media in Africa are implicated in the colonial experiences of African countries (Kasoma, 1996; Nyamnjoh, 2005; Banda, 2008; Shaw, 2009). Banda (2008, p. 84) notes that African media are still "embedded in international media structures". Decoloniality provides a lens to explain the perpetuation of coloniality in the media and other knowledge institutions in the postcolonial state. Decoloniality focuses on countering the "coloniality of power", "knowledge" and "being" (Maldonado-Torres, 2007; Mignolo, 2007; Quijano, 2007). Coloniality refers to a situation where colonial relations of power remain deeply entrenched in spheres of authority, sexuality, knowledge, economy, politics and 'the general understanding of being' (Maldonado-Torres, 2007, p. 232). Maldonado-Torres asserts that coloniality is different from colonialism in the sense that it 'denotes a political and economic relation in which the sovereignty of a nation or a people rests on the power of another nation, which makes such nation an empire' (Maldonado-Torres, 2007, p. 243). Because coloniality survives beyond colonialism, it is about long-standing patterns of power that arose out of colonialism and is maintained in the postcolonial phase through

books, in the criteria of academic performance, in cultural patterns, in commonsense, in the self-image of peoples, in aspirations of self, and in 
so many other aspects of our modern experience. In a way, as modern subjects we breath coloniality all the time.

(Maldonado-Torres, 2007, p. 243)

Thus, decoloniality is a 'shift away from the imperial attitude (both natural and theoretical; Eurocentric, Americancentric or otherwise) and the decolonial attitudes in politics, theory and critique' (Maldonado-Torres, 2007, p. 262). Since the media shape public knowledge about conflict, decoloniality is a useful lens to interrogate "universalised" Western rationality often promoted by the mainstream media about postcolonial conflicts. This is because decoloniality is concerned about the liberation of knowledge and the 'destruction of the coloniality of world power' (Quijano, 2007, p. 177). Quijano adds:

epistemological decolonization, as decoloniality, is needed to clear the way for new intercultural communication, for an interchange of experiences and meanings as the basis of another rationality which may legitimately pretend some universality.

(Quijano, 2007, p. 177)

As an inclusive knowledge paradigm accommodates alternative approaches of understanding conflict in postcolonial contexts such as conflict-sensitive journalism, a more nuanced approach to Peace Journalism championed by Norwegian scholar, Johan Galtung (Galtung, 1998, 2002). Galtung (1998) distinguishes Peace Journalism, which is peace-oriented, from war journalism which he conceives as war/violence propaganda, elite and victoryoriented journalism. According to Galtung, the conflict arena consists of two parties pitted against each other, featuring "Them vs Us", whereby the "US" are humanised and the "them" are de-humanised (McGoldrick and Lynch, 2000). However, Peace Journalism has been criticised for its "naïve realism" (Hanitzsch, 2004). Against this background, Conflict-sensitive journalism has gained traction. It derives its moral underpinning from the fact that professional media can positively influence peacebuilding through dissemination of knowledge about politics, local issues and consensus building (Howard, 2008, p. 2). Conflict-sensitive journalism reflects a refinement of the original values of the news media and is rooted in the belief that the media can be a powerful force for conflict resolution in society. Journalists are equipped with analytical skills to better understand conflict, report it in a context as well as help them avoid the use of stereotypes, narrow perspectives on the causes of conflict. The media can therefore contribute to a wider understanding of conflict through dialogue among diverse communities and can provide information about ways of conflict resolution in society while at the same time maintaining the original core values of the media such as accuracy, fairness, balance and responsible conduct. In this vein, conflict-sensitive journalism has resonance with Afrocentric approaches 
advocated by scholars (Kasoma, 1996; Nyamnjoh, 2005; Banda, 2008; Shaw, 2009). To the extent that conflict-sensitive reporting speaks to the necessity to transform journalistic news values and ground rules, it could be a more viable approach to decolonise conflict reporting in postcolonial societies.

\section{Walking a tightrope: journalistic safety and the reproduction of coloniality}

The majority of journalists who participated in this study constructed electoral violence as ubiquitous rendering some parts of the country as unsafe for journalists to do their job. Some rural areas, which were strongholds of the ruling Zanu PF party, became "no-go areas" for private media journalists due to violence, making it impossible for journalists to gather news. A journalist who works for the private media elaborated on the difficulties of trying to access such "no-go areas" and how he could feel 'it in the air that the environment is not really friendly...even if no one attacked him he could see the hostility in their eyes' (J1). The journalist explained thus:

I went to Mash Central, ${ }^{1}$ you get there and you know, you are afraid, you know you are not free, you are not comfortable. Even as you approach people that you approach you have to be very careful in terms of how you approach, how you approach the people that you want to talk to. Then you get some people who are really very emotional and the you feel your life is under threat at that time.

(J1, Private media Journalist, Male)

This statement illuminates on how election violence was viewed as palpable, inevitable and rampant, making it impossible for some journalists to gain a first-hand experience of the situation, thereby rendering their reports superficial and devoid of historical perspectives since they could not conduct face-to-face interviews or take pictures to authenticate their stories - a key requirement in election violence reporting (Ting Lee, 2010, p. 320).

Beyond superficial journalism, these sentiments reflect the continuities of coloniality within the postcolonial Zimbabwean state whereby life is marked by dichotomies along various axes and "zones of being" characteristic of Santos's "abyssal thinking" (Santos, 2007, p. 1), signifying 'a system of visible and invisible zones established through radical lines that divide social reality into two realms', the realm of "this side of the line" and the realm of "the other side of the line". Thus, the "metropolitan zone" (urban) represents the "zone of being" which is governed by "social regulation and social; emancipation" while the colonial zone (rural) is governed through "appropriation/violence" (Santos, 2007, p. 46). The use of coercion illustrates the extent to which colonial modes and practices of governance continue in the postcolonial phase, thereby questioning the authenticity of "independence" and "freedom" enjoyed by citizens. The hierarchical divisions between the 
citizen and the subject manifest when the citizen uses violence on the subject to affirm their sense of "being" or coloniality of power (Mignolo, 2007). This Hobbesian is graphically captured by Maldonado-Torres (2016, p. 17) when he says life in the zone of non-being is 'a torture chamber making life acquire the overwhelming feeling of it being worse than death'. Although this partitioning of populations into zones of "damnation" (Maldonado-Torres, 2016) and zones of privilege and power is a colonial phenomenon, it is perpetuated through colonial practices of governance such as "black on black" violence which rears its ugly head in postcolonial societies (Ndlovu, 2017).

The polarity between the "zone of being" and the "zone of not being" is further reinforced in the news media through institutional and professional practices such as news sourcing patterns that normalise certain accredited knowledge producers at the expense of others. For instance, most journalists who were interviewed for this study confirmed that they were forced to rely on elitist, "suburban", partisan and institutional news sources, such as the police, politicians and Western-funded non-governmental organisations (NGOs), involved in human rights, ostensibly they "had better access to the situation on the ground". However, besides the fact that such sources were not directly affected by the violence, their perspectives were not only mired in elitism, but also motivated by partisan interests reflective of the political polarity in Zimbabwe.

Although the majority of journalists interviewed for this study denied that their proximity to politicians influenced their reportage, it could be argued that the reliance on conflicted sources such as politicians and partisan NGOs might have loosened journalists' control of the news agenda and the adoption of the political protagonists' news frames might have perpetuated dualistic narratives, resulting in war-oriented reportage rather than de-escalation of election violence.

The fact that most journalists did not have access to rural and peri-urban areas where most of the election violence took place meant that news on election violence was skewed in favour of urban areas while little was reported about the rural and peri-urban areas. A female journalist who works for one of the private-owned newspapers explained how one could risk their life by reporting from "no go areas", resulting in "little in terms of rural coverage" - hence, the limited voices of rural voters (J4 Private Media, Female). In the broader scheme of things, the hierarchical nature of the Zimbabwean society means that their perspectives of rural citizens who bear the brunt of election violence occupy the lower rungs of society and are systematically excluded is discourses on election violence, while the elite, urbanites, and representatives of Western donors and agencies dominate this space. This creates a kind of knowledge apartheid reminiscent of the colonial era with regard to issues of election violence. This implies that an opportunity to balance the Eurocentric neo-liberalist of human rights and alternative perspectives was lost. This war-oriented approach to election reporting, thus, meant very little could be understood about the suffering of 
civilians. Scholars stress the necessity to speak to people behind the frontlines because they are the ones affected by a conflict and are best placed to talk about their story, their suffering because they know what they have lost, and what they have experienced.

This "urban-centric" journalism and the fixation on political elite as sources of news emptied news of its humanistic touch as the media adopted a zero-sum game approach, resulting in suffocation of subaltern voices. This was exacerbated by the lack of human, financial and logistical resources which militated against access to the rural areas as media houses reeled under the economic meltdown and a commercial logic which put premium on profit at the expense of the public interest. A senior editorial staff member of the state-run newspaper, The Herald, explained how resource constraints circumscribed by commercialism negatively affected "comprehensive coverage" of the elections. He pointed out that during the 2013 elections his organisation spent US\$50,000 on the first day of voting and this was expensive for them (E1 Public Media Editor, Male).

A private-media political reporter lamented the lack of election reporting budgets, thereby reducing journalists to what he described as "Desktop Journalists". He explained:

I was disappointed, for example in our newsroom, there was no election budget. I thought that, I thought you know we would have an election budget. To tell you the truth, eh, I don't know because I am not blaming her or him, but as journalists we might ask ourselves why during an election there was no budget. From my own perspective, I don't think that my bosses appreciate the importance of having an election budget. Yes, things are tough, the economy is in the doldrums but I believe that when you have got a budget there is ah...even a budget for three trips outside Harare, so that you are not restricted to, to, to Desktop journalism... What we saw much is that, it seems foreign journalists had more resources to cover our elections, were more prepared to cover our elections...For me I was then forced to squat at some foreign journalists who had the resources.

(J3 Private Media, Male)

This view was corroborated by Dumisani Muleya, then editor of the privately weekly, The Zimbabwe Independent, who noted how journalists were "relying on phone calls" and "talking to interested players" who had "their own version of events to advance their agendas", thereby limiting their ability to reflect on stories correctly "since they could not physically travel to the ground to able to interview people there". Muleya noted how "Desktop journalism" was increasingly becoming due to the proliferation of social media as journalists would 'just sit in the offices, wait for posts on the social media, Tweets, Facebook' (Interview with Dumisani Muleya, 9 September 2013). 
That some journalists were forced to "piggyback" on foreign journalists due to the lack of resources to cover election violence is a serious indictment on the neo-liberal commercial logic of the media in the postcolonial context and demonstrates the extent to which economic inequalities expose local journalists to neo-colonialist journalistic news framing practices which normalise hegemonic relations between the West and the Global South. When local journalists are embedded within foreign journalistic crews, it is inevitable that they will parrot journalistic practices of those and their framing of the local reality. Local journalists become appendages of Western media, and amount to a tacit endorsement of the "epistemic superiority" of the better resourced Western media.

\section{Political pressure, self-censorship and editorial manipulation}

Apart from coercive measures, continuities of coloniality found expression through political pressure, editorial influences and self-censorship. These forces resulted in the lopsided selection and framing of election violence news. Most journalists pointed out how political pressure, editorial influences and self-censorship acknowledged negatively influenced election reporting. Given the deteriorating economic conditions in Zimbabwe at the time and the fact that politics is a source of patronage activities, violence became a means to an end. A state media editor illustrated how sometimes they get blackmailed by politicians who convene press conferences to make "baseless" allegations of election violence against opponents only to discover that thereby misleading the media.

Sometimes politicians they tend to say out things without backing, without evidence. So, we try to make our own investigations.

(E1, Public Media Editor, Male)

While this journalist alluded to the politicisation of election violence, he tended to downplay politicisation in his newsroom. The then editor of News Day, Vincent Kahiya, acknowledges the propensity to politicise election violence by politicians, but placed emphasis on how politicians burden the media by demanding "good press" and the fact that political parties "have got a line that newspapers must report on". He added: "And if you do not do that there is always the accusations by the other political party. So sometimes you ask yourself, do you trade that very very thin line and say, no we will be very neutral?' (Interview with Vincent Kahiya, 9 September 2013).

Although he agreed with Kahiya about the pressure exerted by politicians on the media, the state-media journalist claimed they spurned any attempts to manipulate them by politicians as they had "mastered ways of dealing with politicians" and managed to publish balanced (E1 Public Media Editor, Male). 
A more serious form of political pressure was when journalists were threatened with unspecified action by politicians to force them to drop uncharitable stories about them or their political party. Sunsley Chamunorwa, a veteran journalist and editor of the Financial Gazette, indicated how his newspaper was forced to drop some stories on election violence because of threats by ruling party politicians. He gave an example of a story in 2009 which stated that 'in 2008 an excess of 200 people were reportedly killed in politically motivated violence' which got him into trouble even if it "was a statement of fact" (Interview with Sunsley Chamunorwa, 11 May 2015). Chamunorwa added that depending on "what the ruling clique" wanted, the owner of the newspaper, who was a government official, would come up and say 'you can't report on so and so or such and such an institution because it may actually end up affecting Zanu PF'. Chamunorwa said he was 'stifled big time' (Interview, 11 May 2015).

A journalist from the same newspaper narrated how he was falsely accused of "insulting the president" by a ruling party politician, forcing him to drop the story because he feared arrest. This meant that journalists lost their monopoly to determine the news agenda to politicians, resulting in the dominance of a war journalism.

Although both private and state media agree about the toxicity of coercion, political repression and editorial manipulation, state media journalists were more nuanced, arguing that they try to maintain editorial independence by following the "rules, ethics and guidelines of journalism" (E1 State Media Editor, Male). Another state media journalist, while agreeing that ownership had a bearing on the way they reported election violence, argued that the overriding guiding principles in the reportage was "the national interest". However, some private media journalists dismissed the state media's professed "national interest" as a nebulous concept used to mask "partisan" by the state media (J3, Private Media, Journalist).

The polarised views between the private and state media reflect historical political divisions in the Zimbabwean society, but are a carryover from colonial times. While the use of repressive modes of governance reflects contemporary neo-patrimonial politics and socio-economic and political schisms in contemporary times, they are rooted in a genealogy of paternalistic modes of governance which emerged out of colonialism. Although they have their origins in Western "modernity and colonial encounters" (Quijano, 2007), continuities of coloniality have survived beyond colonialism and manifest themselves through repression, cooptation and other colonialist practices meant to secure or retain power for the political elite. Ylonen (2009, p. 51) is on point when he argues that the transition to independence in Africa 'merely changed the composition of the managers of the administration' but its modalities of governance based on 'a narrow base of social forces and coercive measures emphasising the state as a device of violent repression and not a source of security' for all citizens remained intact. 
This view is clearly at odds with framings of violence in Africa which is "pathologised" through neoliberal discourses whereby election violence is viewed as signalling breakdown of the "rule of law", violation of "human rights" and "good governance". Such discourses perpetuate distorted, stereotypical and "Orientalist" (Said, 1978) perceptions whereby the post-colony is "invented" and "inverted" (Mudimbe, 1988) as "hellish" and "precarious place of existence" where the conventional ethics of war do not apply (Maldonado-Torres, 2007, p. 17).

\section{Polarisation and partisanship: the ugly side of advocacy journalism}

A central feature through which colonial tropes were sustained was the Manichean lens through which election violence was reported. It reflected enduring genealogies of colonial practices whereby society was constructed as consisting of "US" and "Them". The most conspicuous polarity pitted the state media aligning themselves to the ruling Zanu PF party while the privately owned media unapologetically defended the opposition, particularly the Movement for Democratic Change (MDC) led by Morgan Tsvangirai. In the ensuing hegemonic struggle, election violence reporting was characterised by "Othering" which often degenerated into advocacy" journalism and labelling. Bemoaning partisanship, the then Editor-in-Chief of Newsday, Vincent Kahiya, attributed partisanship to the fact that journalists are "political creatures" with "an inclination to become activists", because they had political aspirations which were betrayed by their "appetite to root for political parties in their personal capacities" and how this was "reflected in the stories" (Interview, 9 September 2013).

His view was corroborated by Dumisani Muleya, the editor of The Zimbabwe Independent, who lamented the "tendency for journalists to take positions" along political lines. He observed:

You try to encourage people to see things in binaries which is not what you should. What you should be doing is to report in such a manner that on one occasion if I take the story in The Herald and put it in The Independent and take the one in The Herald and put it in The Independent the readers will not know where it was written. That should be the situation. So, one of the limitations we have here is the polarisation of the media and the partisan nature of the coverage of issues, particularly elections.

(Interview 9 May 2013)

To the extent that partisanship is the clearest evidence of weaponisation of the media for political power, it is a mirror of colonial era kind of the bifurcation of society into "zones of being" and "zones of non-being" whereby citizen solidarity is undermined by the divide and rule power retention strategies of the political elite. Media solidarity is thus replaced polarity, advocacy journalism and "Othering". 
A private media journalist explained how in their newsroom journalists would ask each other "which political party one rooted for" which resulted in unbalanced stories. She explained how in her newsroom there were no more journalists but "activists" (J4 Private Media Journalist). As advocacy journalism took root, some stories were either toned down or completely jettisoned from the news agenda, resulting to one-sided reports on election violence. This "rigging" influenced the public's moral evaluations and causal interpretations about election violence.

The journalist quoted above explained how one could be labelled "a Zanu PF mole" or a member of the Central Intelligence Organisation (CIO) for writing positively about Zanu PF, making it impossible to balance stories on election violence as stories gravitated towards "the extremes" (J4 Private Media, Female).

These journalistic practices are shaped by political power dynamics and have historical antecedents in the colonial setting whereby knowledge production was centralised for the preservation of political power by the minority elite class. Just like in the colonial era, journalism is still being weaponised for political purposes rather than maintaining societal harmony. The fact that people who are supposed to be unified under the umbrella of one professional body use toxic and derogatory labels against each other is indicative of this extent weaponisation, the destructive nature of power politics on the social fabric - the same way coloniality perpetuates itself through anti-democratic practices and modalities of governance.

While agreeing with their private media counter-parts that election violence lends itself to polarisation, they attributed the "use inflammatory language or hate speech to "Other" media' (J1 Statement Journalist), thereby underlining the polarities entrenched in the Zimbabwean society. The contours of divisions in the media are vocalised through narratives that hark back on neo-coloniality graphically illustrated by a state media journalist who blamed "western countries" for interfering in Zimbabwean affairs, accusing them of operating a "megaphone diplomacy" whereby "they pretended to have a telescope vision to know what was happening in Zimbabwe' by blowing out of proportion any skirmishes in the country so that Zimbabwe is put on the United Nations agenda. He added:

Any skirmish in Zimbabwe you will find the Secretary of State of the US will be on CNN condemning it, the Canadians, the Australians and so on. Any skirmish between two people probably a bottle store it hits the headlines. So, we always try to get other voices, the voices of our African brothers, to, to, to tell the story that, because they will have people on the ground. They have embassies in Zimbabwe. They will have observers and monitors on the ground. So, we always try to get them to corroborate our story because we will be a lone voice basically, ranged against these powerful global media that are trying to portray a picture of a crisis in Zimbabwe in order to subvert the electoral outcome which 
they always know goes against them. Because the politics that they are trying to import into Zimbabwe is an alien politics that is at variance with what the needs of the majority are.

(E 5, State Media Editor)

These statements highlight that polarities in the Zimbabwean media are, justly or unjustly, constructed by some as rooted in the neo-colonial enterprise of the West whereby the postcolonial state is caught up in a struggle to assert its sovereignty in a neo-colonial set-up, in which circumstances the media 'become a pawn on the politics of power to be deployed in the service of state elites and the struggle for the hearts and minds of the citizenry' (Banda, 2008, p. 93). In these circumstances, journalism is weaponised against society and becomes a source of conflict and a negation of peace.

\section{Concluding remarks}

This chapter examined the extent to which election violence reporting in the Zimbabwean print media after the turn of the century was mired in continuities of coloniality. The chapter has demonstrated how long-standing practices of coloniality and old time modes of governmentality embedded in institutional, structural and professional practices of the media manifest themselves in the postcolonial context. One of the most intriguing findings of the study is the extent to which journalism has been weaponised for political agendas during electoral contexts. The political environment in which the media operated and the war-oriented approach which they adopted betrayed the historical contours of bifurcation in the Zimbabwean society which found expression through polarities, coercive and repressive modes of governance practiced during the colonial era. These deficiencies go beyond ethical shortfalls, but speak to larger epistemic interventions; the need to decolonise conflict reporting in postcolonial contexts whereby journalists incorporate elements of the conflict-sensitive journalism model and a deliberate subversion of the dominant Western-based philosophy of journalism.

\section{Note}

1 Mashonaland Province is one of Zimbabwe's ten provinces.

\section{References}

Banda, Fackson (2008) African Political Thought as an Epistemic Framework for Understanding African Media. Ecquid Novi, 29(1): 79-99.

Chalfont, Lord, Soustelle, Jacques, Phodhoretz, Norman, Lowenthal, Gerhard, Will, George, and Elkins, Michael. (1980). Political Violence and the Role of the Media: Some Perspectives. Political Communication, 1(1): 79-99. 
Galtung, Johan. (1998). After Violence: Reconstruction, Reconciliation, Resolution: Coping with Invisible and Visible Effects of War and Violence. Princeton, NJ: Transcend.

Galtung, Johan. (2002). "Peace Journalism - A Challenge". In Journalism and the New World Order, Volume 2, edited by Wilhelm Kempf, and Luostarinen Heikki. Gothenburg: Nordicom, 260-280.

Hanitzsch, Thomas. (2004). Journalists as Peacemaking Force. Peace Journalism and Mass Communication. Journalism Studies, 5(4): 483-495.

Hoagland, Sarah Lucia. (2020). Aspects of Coloniality of Knowledge. Critical Philosophy of Race, 8(1-2): 48-68.

Hobart, Mark. (2007). "Round Up the Usual Suspects: Some Radical Implications of Indonesian and Euro-American Media Coverage of "Terrorism" Attacks". In Media and Political Violence, edited by Hillel Nossek, Annabelle Sreberny, and Prasun Sonwalkar, 183-210. Cresskill: Hampton Press.

Howard, Ross. (2008). “Conflict Sensitive Journalism: Where Does It Fit In?” Paper Presented at the United States Institute for Peace Workshop on Media, Conflict and Peacebuilding Workshop, June 25-26, 2008.

Kasoma, Francis. (1996). The Foundation of African Ethics (Afriethics) and the Professional Practice of Journalism: The Case of Society-Centred Media Morality. Africa Media Review, 9(3): 93-116.

Lynch, Jake, and McGoldrick, Annabel. (2006). Peace Journalism. London: Hawthorn.

Maldonado-Torres, Nelson. (2007). On Coloniality of Being. Contributions to the Concept of Development. Cultural Studies, 21(2-3): 240-270.

Maldonado-Torres, Nelson. (2016). Outline of Ten Theses on Coloniality and Decoloniality. Frantz Fanon Foundation. Retrieved from http://caribbeanstudies association.org/docs/Maldonado-Torres_Outline_Ten_Theses-10.23.16.pdf. Accessed 14 March 2020.

Mamdani, Mahmood. (2003). Making Sense of Political Violence in Post-Colonial Africa. Socialist Register, 39: 132-151.

McGoldrick, Annabel, and Lynch, Jake. (2000). Peace Journalism: What Is It, How To Do It. Geneva: Transcend.

McQuail, Dennis. (2013). Journalism and Society. London: Sage Publications.

Meadow, Gadi. (2009). Political Violence and the Media. Marquette Law Review, 93(1): 231-240.

Mignolo, D. Walter. (2007). Introduction: Coloniality of Power and De-Colonial Thinking. Cultural Studies, 21(2-3): 155-167.

Mudimbe, Y. Valentin. (1988). The Invention of Africa: Gnosis, Philosophy and the Order of Knowledge. Bloomington: Indiana University Press.

Ndlovu, M. (2017). Manufacturing Black on Black Violence in South Africa: A Decolonial Perspective on Mfecane and Afrophobia/Xenophobia in South Africa. Journal of African Renaissance: Multi-Inter-Transdisciplinarity, 12(2): 17-109.

Norris, Pippa. (2000). A Virtuous Circle: Political Communications in Post-Industrial Societies. New York: Cambridge University Press.

Nyamnjoh, Francis. (2005). Africa's Media, Democracy and the Politics of Belonging. Pretoria: Zed Books.

Odhiambo, Sharon Anyango. (2017). The Media and Election Violence in Africa: Lessons from Kenya. Wilson Center Africa Program Policy Brief No. 11. Retrieved from https://www.wilsoncenter.org/sites/default/files/media/documents/ 
publication/policy_brief_-_the_media_and_election-related_violence_in_ africa_lessons_from_kenya.pdf. Accessed 14 February 2020.

Quijano, Anibal. (2007). Coloniality and Modernity/Rationality. Cultural Studies, 21(2-3): 168-178.

Reif, Megan. (2011). Making Democracy Safe: Institutional Causes and Consequences of Coercive Campaigning and Election Violence. Unpublished PhD Thesis, Department of Sociology, University of Michigan, Ann Arbor. Retrieved from http://www.meganreif.com/makingdemocracysafe/2011/10/10/114. Accessed 18 December.

Said, Edward. (1978). Orientalism. London. Penguin Books.

Santos, Boaventura de Sousa. (2007). Beyond Abyssal Thinking: From Global Lines to Ecologies of Knowledge. Eurozone. Retrieved from https:// modernidadesdescentralizadas.com/biblioteca/beyond-abyssal-thinking-fromglobal-lines-to-ecology-of-knowledges-2/. Accessed 31 May 2020.

Stremlau, Nicole., and Price, Monroe. (2009). Media, Elections and Political violence in Eastern Africa: A Comparative Framework. London: Annenberg-Oxford Occasional Paper in Communications Policy Research.

Thussu, Daya. (2009). Turning Terrorism into a Soap Opera. British Journalism Review, 20(1): 13-18.

Ting Lee, Seow. (2010). Peace Journalism Principles and Structural Limitations in the News Coverage of Three Conflict. Mass Communication and Society, 13(4): 361-381.

Ylonen, Aleksi. (2009). On Sources of Political Violence in Africa: The Case of "Marginalising State" in Sudan. Politi y Cultura, Otono, num, 32: 37-59.

Zimbabwe Electoral Support Network. (2008). Report on the Zimbabwe 29 March 2008 Harmonised Elections and 27 June Presidential Run-Off. Harare: ZESN. 


\title{
3 Conspicuous and performative blackness as decolonial political branding against the myth of the post-colonial society
}

\author{
A case of the EFF \\ Rofhiwa Felicia Mukhudwana
}

\section{Introduction}

In the black-majority country that emerged from both colonialism and apartheid, and in the era of decolonisation wherein a significant number of voters are becoming black conscious, blackness is commodified, conspicuously performed and appropriated for various reasons including political identification. Although political parties' notions of blackness are substantially legitimate to use as an evaluation tool in political behaviour (Walters 2007, 13), there has been a paucity of scholarship on the use of blackness in political branding (Fuller 2010, 289). Political marketing research indicates that brands and branding are crucial elements in politics as they can be utilised in positioning party branding to differentiate themselves, to shape perception and to attain a competitive advantage (Pich \& Dean 2015). While scholars have examined political branding in Africa, fewer, if any, have focused on how branding targets citizens via racial, ethnic or class differences, particularly how blackness can/has been used as a political brand. Even fewer studies have approached blackness as a political branding from the perspectives of voters. In practice, however, post-colonial countries like South Africa (SA) are no stranger to racial and ethnic political branding. For example, the Azanian People's Organisation (AZAPO) emergent from the Black Consciousness Movement (BC) and the Pan African Congress of Azania (PAC) in SA were actually founded on the idea of black solidarity while the Inkatha Freedom Party (IFP) was and is still espoused by its ethnical alignment to the Zulu culture. What has been lacking is the theoretical and academic engagement of this phenomena, both in history and in its current incarnation within the "new" decolonial turn. While scholars acknowledge political branding, there is limited knowledge of the broader societal acceptance and understanding of political branding, particularly one that utilises the emotive realities of blackness (the black condition). The research question is: how would voters react to the emotional and performative branding of blackness as an ideological political position? The Economic Freedom Fighters (EFF) political party in SA is used as a case study.

DOI: $10.4324 / 9781003111962-3$ 


\section{The conceptual framework: blackness as concept}

Blackness is a multidimensional concept that refers to "the conception of what black subjectivity and identification signifies and symbolises in society' (Dei 2018, 119). It is both an identity and an experience - that is shared and contested. Blackness is contingent on different histories and specific geographies. Johnson (2003) called blackness an elusive signifier 'too slippery ever beyond the reach of one's grasp. Once you think you have a hold on it, it transforms into something else'. The notion of what constitutes blackness has changed over the years and through generations. It is both spatial and temporal. It is also theoretically disparate in meaning. For instance, Fanon, Ngũgĩ and Biko approach blackness differently. While Fanon and Ngũgĩ take the Pan-Africanist view of solidarity of the skin, Biko emphasises the (local) agency of the South African apartheid struggle and the black experience. In his case, the black experience being apartheid and the quest for liberation. In my definition today, blackness as experience refers to the treatment of race as sets of enacted behaviours of the lived experiences that are influenced by the socially constructed meaning of the perceived physical difference of "being" black under the structural conditions afforded in the particular geo-politics. This definition emphasises that the performance of race (blackness) is the result of both agency and structure. Race is defined by both the subject and the situation (Calmore 2005, 100). Thus, context becomes a key point in understanding notions of blackness. Blackness today is often tied to nationalism, ethnicity, tribe, language and location, especially within the South African context. Albeit simplified here, the definition of blackness is cumbersome because the black population is not monolithic. Hence, the meaning of blackness is neither uniform, nor singular, nor static. For example, Wright (2016) and Dei (2018) draw dichotomies between the blackness of the diaspora and what is termed "African blackness". As blackness is situational in its cultural performance, we delimit our analysis to the South African notion of blackness.

Biko's definition is contrary to Apartheid architects' treatment of race as fundamentally biological; see the Population Registration Act of 1950 that distinguish between the Bantu (of African tribe), the white and the coloured who is neither Bantu nor white. For Biko $(2017,52)$, being black is not a matter of pigmentation (skin colour) but a reflection of a mental attitude. $\mathrm{He}$ defined 'blacks as those who are by law or tradition politically, economically and socially discriminated against as a group in the South African society and identifying themselves as a unit in the struggle' (ibid). It cuts across the standard understanding of race to include the Native Bantus, the coloured and the Asiatics. Biko's definition is explicitly localised to SA (Epistein 2018, $100)$, further proving the geo-politics of the term blackness. This definition is therefore contrary to the universalism of the Pan-African notion that sought to unify blackness under a singular term of African Unity. The primary definer being the visible black body. As espoused by Ngũgĩ wa Thiong'o (2012), 
'Africa has to reclaim the black body with all its blackness' and that Africa is for Africans at home and abroad.

The consequence of the exteriority of the black skin cannot be denied. Skin colour alone is an inadequate yet sometimes socially, culturally and polemically necessary signifier of blackness (Johnson 2003, 19). On the passage, "look mommy, a negro", Fanon ([1952] 2008) describes a world that denies his inner life. In his view, whiteness (the structure) also constructs blackness - the superstructure and the base relatively hold the material influence to the type of blackness possible. Even Biko $(2017,55)$ observed, 'we recognise the existence of one major force in South Africa. This is white racism. It is the one force against which all of us are pitted'. Ngũgĩ wa Thiong'o (2012) illustrated how racism expresses itself with absolute "certainty" in profiling blackness based on the colour of the skin. The certainty that can condemn one to an early death as the situation is with the killing of black lives in America by the police. 'The certainty is based on a negative profile of blackness taken so much for granted as normal that it no longer creates a doubt' (Wa Thiongo 2012). Lewis Gordon $(2015,49)$ calls this "epistemic closure" which closes off efforts at further inquiry. Such is the cause of an overdetermined representative identity that is commanded and declared from the exterior. Fanon ([1952] 2008, 93) laments that 'I am overdetermined from the exterior. I am not the slave of the "idea" that others have of me but of my appearance'. This brings truth to the paradox of the hypervisibility and oblivion of blackness. That I am hyper-visible in my representation of all that is black but within the oblivion of who I truly am. This, according to Gordon $(2015,48)$, causes the erasure of the black experience as 'black experience suffers from the failure to bridge the gap between subjective life and the world'. What of experience then when the black's lived life is superseded by the appearance of namelessly and ahistorically just being black.

Biko adds a psychological criterion to blackness (Epstein 2018), which meant at the time the identification with the struggle against racism. This being the mental attitude of defiance against the inferiority complex of coveting whiteness. Today, it could simply mean feeling and acting black (agency) - thus discerning the performative nature of blackness as lived experiences which I seek to emphasis on this chapter. On the question, what do blacks want? Fanon and Biko differ in explaining what is withheld by the white system. For Fanon ([1952] 2008) what is withheld by the white system is the failure of mutual recognition as human. So blacks are dehumanised in the zones of non-being. Biko accepts but takes it further that what is withheld and sought by blacks is agency. For him, the distinction between whites and blacks is the capacity to act (Epstein 2018). Black agency means the reconstruction of the tools of blackness (Calmore 2005, 109).

Costa Vargas $(2006,476)$ defined blackness as a result of two types of processes. The first process is as a result of racialisation emanating from hegemonic institutions and practices, such as apartheid (and colonialism). I shall refer to this as "structured blackness" even when the dominant concept 
is systematic racism. The second refers to blackness as a result of our own agency of resistance, pride, hope and lived experience. I shall refer to this as "black agency" as reinforced by Biko black consciousness. This is the aspect of blackness that is ratified, packaged, commercialised, marketed, branded and performed. This duality of the meaning was observed by Stevens, Bell, Sonn, Canham and Clennon (2017) who defined blackness (1) as the consequence of being made black in the world by the others and (2) as a process of self-definition (self-agency). In exploring the negotiation of EFF's blackness as political branding by voters, it should be poised to observe the negotiability between these two processes of "becoming" black in SA.

\section{The theoretical framework: blackness as performance}

Blackness is the undeniably experience of black people, but it is also a restorative performance. Blackness as performance refers to how blackness is signed and embodied in the everyday life (for us, in politics). Performance theory emphasise that we invent bodies with meaning. Although theories of performativity focus primarily on the performance of gender, Johnson $(2003,19)$ engages a discussion about the performativity of race. Blackness offers a rethinking of performance theory by forcing it to ground itself in praxis such as racially oppressive systems (ibid). For example, Manthia Diawara characterises black performance studies as examining 'several interrelated notions, among them that "performance" involves an individual or group of people interpreting an existing tradition reinventing themselves in front of an audience, or public' (Calmore 2005, 109).

Rather than being innate, race is only real to the extent that it is performed. The recognition of the performance nature of race and identity opens the possibility for contesting their reified status which calls into question what it means to be black and the degree of blackness that is politically acceptable and that which is not. The concept of black authenticity implies the possibility of faking. The contestation is on the dichotomy between lived blackness and its representation. The authenticating of blackness is an attempt to secure a particular attribute of blackness. It is performed in order to circumscribe the parameters of inclusion and exclusion. In so doing, it becomes a contested political term, sometimes seeking to exclude the middle class, femininity and homosexuality for example. Despite Stuart Hall having said blackness has no necessary class belonging, 'class represent a significant axis and divisiveness within black communities' (Johnson 2003, 22). Authentic blackness is often associated with the poor working class, rendering black middle class as inauthentic and apolitical. Black economic mobility is said to breed assimilationists and race traitors who becoming politically and ideologically white, i.e. adopting white politics. This is a misnomer because it is the structural conditions that breed a particular type of blackness and once those conditions are removed in upward mobility so will the particular form of blackness leading to the pluriversality of blackness, each authentic in its own kind. 
Performance does not foreclose the discursive signifiers that undergird the terms of its production (Johnson 2003, 18). This means that 'externally imposed racial categorization remains an important part of the script' (Calmore 2005, 109). The performativity of blackness is externally influenced by two gazes: the hegemonic white gaze and the black gaze (Canham \& Williams 2017, 24). Both gazes attempt to homogenise blackness into predictability and stagnation. Black identity is often performed against a backdrop of white narratives. According to Sithole (2016), 'the white gaze is hate of the black subject'. The white gaze is systematic and operationalised by authoritative discourses, legal injunctions and numerous socio-political apparatus and practices - that control, interiorise and negate blackness. Accordingly, the white gaze seeks to discipline blacks, reminding them that despite democracy and increasing black mobility, white supremacy and white correctness remain uncontested. White hegemony is maintained by black self-disciplining into performative expectations of whiteness. The black gaze however does not gaze back at whiteness (although starting to), but rather at other blacks performing "a black-on black surveillance". Canham and Williams (2017) concluded that the black gaze negotiates blackness in terms of three indicators: physical identity, performance and class (discussed in previous sections).

Blackness as confirmative performance posits that one claims membership within the social group. This aligns with Biko's delineation that 'black consciousness is in essence the realisation by the black man of the need to rally together with his brothers around the cause of their operation'. Performing blackness is increasingly complex when issues of immigration and race intersect. The other relates to bi-racialism. Establishing and maintaining solidarity is a challenge for the black diaspora in the United States. The same could be the case in South Africa. While some immigrant blacks may emphasise their solidarity with the locals, others prefer to distance themselves from the "blackness" of the locals. However, some locals feel that black immigrants are replacing them (in economics and in culture).

Performance in politics is associated with populism. In application of the performance theory, this chapter cannot ignore the discussion of the EFF brand of politics built around the politics of spectacle reminiscent of populism. Populism can be defined 'as an ideology which pits a virtuous and homogenous people against a set of elites and dangerous others who are together depicted as depriving the sovereign people of their rights, values, prosperity, identity and voice' (Abertazzi \& McDonell 2008, 3). When it comes to blackness as political branding, this would be pitting blackness against the white system. There is significant literature around various types of populism in South Africa: populism as political communication styles (Mukhudwana 2020), populism as performance (Nieftagodien 2015; Mbete 2016), religious populism in politics (Forster 2019), populism as policy discourse looking at the radicalisation of land reform (Zukowski 2017) and charismatic populism focused on liberation movements (Melber 2018). What is posited on 
this chapter is closer to racial/ethnic populism. Racial or ethnic populism appeals through performance and self-presentation to a particular segment of society as the "pure" people. The departure, however, is on grounding this study on blackness as political branding and on the performativity of both blackness and branding (rather than on populism as theory).

\section{The literature review}

\section{Blackness as an ideological political brand}

In political communication, political branding is based on the principle that political parties can be managed as brands (Milewicz \& Milewicz 2014). The implication is that brands and branding are a crucial element in politics. Political parties can use positional branding to differentiate themselves, to shape perception and to attain a competitive advantage (Grimmer \& Grobe 2017). A brand is a multidimensional construct with tangible features like trademark, names, colours and logos, and intangible features like behaviour (performance), relationships, history, experience and heritage (Milewicz \& Milewics 2014, 236). These work together to construct the image and reputation of the political party and its leaders (Grimmer \& Grobe 2017). Political parties embrace branding for its value towards long-term relationships with voters. Brands are complex constructs, co-created and co-managed by many actors. The media is coming to accept political branding as a multifaceted part of normal politics. While scholars acknowledge political branding, we have limited knowledge of the broader social acceptance and the understanding of political branding.

In this section, I explain ideology positioning as an element of political branding as an act of performance or self-presentation. The success of a brand depends on the efficiency of appropriating referent systems that are not already appropriated by competitors (Serazio 2017, 230). The same is true for political branding. Political parties face a similar challenge of finding brand differentiation that is not yet colonised by others. This chapter identifies the branding positioning of the EFF within the concept of black radicalism which is no longer appropriated amidst the myth of a rainbow South Africa. Even though black radicalism is not new to South African political ideologies, its reappearance in the "post-apartheid" is a strong differentiation factor for the EFF. However, during the apartheid times, this ideological positioning was inherent and not performative or invoked as it is now. Granted, within the EFF's brand positioning that apartheid is not over, a counter-argument can be made that a black radicalism ideology today is not invoked (as a ghost of the past) or performed but a necessitated lived reality.

Branding in this chapter is approached mainly from the point of positioning. Brand positioning is an organised system for finding a window in the mind. In simple words, brand positioning is about putting a brand first in a 
customer's thought process against all other related or competitive brands. A political party not only has to position itself as being unique but must also position its uniqueness on top of all other political parties and at the forefront of voter's discourse. They must also attach an emotion to that uniqueness. Therefore, the manner in which a political party positions its brand in the political marketplace is crucial. It seems in political branding, credibility is based on emotional implications rather than policy orientation, political performance and issue positioning. This means that what a political brand means or represents (sign value) is divorced from the material referent of what it does (use value). As such, the socio-political and cultural positioning of brands is becoming more paramount than their functional worth (Serazio 2017, 226).

Blackness as an ideological branding can bring forth a sense of belonging for voters and communicate certain values. The concept of ideology was coined by Destutt de Tracy in 1976 in reference to 'the science of analysing ideas' (O'Reilly 2006, 264). Later, ideology came to 'characterise an extreme political body of ideas' (ibid). Such is the definition reinforced in this text. Ideology has come to reflect a wider scope of application inclusive of class, race, gender, sexual orientation and others. A political party can position itself within a selective range of issues in a certain ideological continuum. Ideological political branding is ruled by two interrelated aspects. Those are hot issues and emotions. Emotion rather than reasoning is favourable in political branding. This is because politics is subjective as opposed to most products whose utility value can be proven or disproved. The emotionalising of political ideologies and their related issues and policies often leads to political polarisation - which inherently makes politics a competition with winners and losers, friend and foes, pure people and the corrupt elite.

The positioning of issue positions (and even the ideological brand itself) can be performed for attaining hypervisibility (brand awareness). Such is the domain of the EFF party which follows an issue-based model that tends to successfully position it on top of the spotlight. In political branding, this is how issue branding works:

the voter must be aware of the issue; hold an attitude towards it; understand the policy stance of the political parties towards the issue; and vote for the party that most closely matched his or her view on the issue.

(Dean, Croft \& Pich 2015, 21)

In general, citizens gravitate towards universal issues such as health, crime and the economy, for example. In South Africa, issues such as land, racism, economy, service delivery, employment and labour hold prominence in politicking, in the media and in citizen discourses. The success of a political brand can be measured by the effectiveness to which it is perceived better able to respond to key issues at the time. So issue management and issue positioning are essential elements of political branding. 
What is considered in blackness as political branding are three types of blackness: (1) cultural blackness (popular culture, tradition, everyday life) (Collins 2006), (2) economic blackness in reference to class and the position of blacks in the economy (Canham \& Williams 2017) and (3) political blackness relating to black issue politics (Walters 2007; Sithole 2016). Cultural blackness, political blackness and economic blackness can work together and reinforce each other in designing a coherent political campaign. However, contestations or discrepancies among cultural, political and economic blackness are possible. For instance, Walters (2007) described the contestation between Barack Obama's cultural blackness and his political blackness. He argues that although Obama was able to prove his cultural blackness in terms of skin colour and lived experience, he was not able to prove his political blackness in his presidential campaign because he chose to remain race-neutral in policies and issues. Similarly, white media has attempted to display a discord between the EFF's political blackness and economic blackness on the bases of class, the affluence of their education and their conspicuous consumptions.

I will expand a little on political blackness. First, I make reference to Sithole's (2016) concept of the "white liberal façade" of liberty. He argues that the concepts such as freedom, justice and equality are determined outside the black subject. They apply primarily to whiteness as a category that is humanised. They remain external and outside the political experience of most blacks. As long as the black is dehumanised in the zone of non-being, they will remain outside the practical application of the white liberal façade. Because of the negative consequences of Apartheid, the trust of black people is determined by the political parties' willingness and ability to represent black-interest issues in the political system. Black issues are those specific to black voters, particularly those which they feel disproportionately represented or unfairly treated. This projection is what black voters will vote for as they hold a decisive variable in political identification, alignment and voting in South Africa.

Blackness in political branding is seen as an identification marker of black resistance, agency, political consciousness and black affirmation. This is what is packaged, performed and branded as political capital. For example, Bourdieu (1986) identifies cultural resource/political capital as a status generating tool that is projected in three ways: (1) embodied (status-making taste, skills and practices), (2) objectified (status-making objects such as homes, cars and clothing) and (3) institutional (formal status markers such as education and occupation). Blackness in SA politics is not only an ideological maker or social justice, but also a status marker of black consciousness, political consciousness, of education - as in an avid reader of political literature, decolonisation and radicalism. So political blackness does not only identify the political party, but also the voter who associates with the political party. 


\section{The chronological trajectory of black issue politics in South Africa until the EFF}

South Africa became a democratic country in 1994 after the first majority election. Racial and ethnic populism is not a South African phenomenon but evident in many parts of the world were injustices against blacks have materialised. While ethic populism is dominant in African countries with fewer white settlers, racial populism seems prominent in white settler African countries. The purpose of this history section is to provide context to blackness as an ideological political position and to describe the development of black issue politics in SA. Such would illustrate the reincarnation of blackness in the post-1994 South Africa.

\section{The PAC (Pan-Africanism)}

The Pan Africanist Congress of Azania (PAC) was formed on 6 April 1959 with Robert Mangaliso Sobukwe as its president. The PAC was formed by a breakaway group of Africanists with an agenda of African Nationalism and continental unity inspired by Kwame Nkrumah. They felt betrayed by the multi-racialism adopted by the ANC within the frame of the Freedom Charter in 1955. Instead, they advocated for Africa for Africans. Pan-Africanism was both an ideology and a positional issue. In this, PAC envisioned a radical land redistribution policy and Africa-wide unity - with the slogan "Izwe Lethu" (Our Land). The other issue positioning was racial separatism, choosing to define a black by physical identity and also putting blacks as their primary concern. Black consciousness in the form of black agency was another issue that identified the politics of the PAC. The EFF has adopted the African nationalist issue position from the PAC. This is demonstrated by their position regarding the opening of African borders. That South Africa belongs to all black Africans, including black immigrants.

\section{INKATHA (ethnic traditionalism)}

The Inkatha Freedom Party IFP (Inkatha Yenkululeko YeSizwe) was founded in 1975 as the Zulu National Cultural Liberation Movement by Chief Mangosuthu Gatsha Buthelezi. The purpose was to promote the Zulu culture in the form of ethnic nationalism directly incorporated into the secluded Apartheid Bantustan political structures. As a political party, Inkatha 'established itself as a patriarchal movement that was rooted among the traditional leaders such as the amakhosi/izinduna in the rural areas of KwaZulu and Natal' (Sithole 2011, 1171). IFP was positioned as the internal struggle against apartheid after the ANC was banned which is incorrect because such Zulu nationalism reinforced the ethnic divisions imposed by the apartheid ideology of divide and rule. This kind of ethnic blackness was contrary to the ANC version of blackness based on unity of all non-whites. 


\section{AZAPO (black radical nationalism)}

The Azanian People's Organisation (AZAPO) was formed on 28 April 1978 following the student uprising of 1976. Azapo draws its ideology from the black consciousness movement espoused by Steve Bantu Biko and thus considers itself heir to the philosophy. Although membership was open to blacks, coloureds and Indians, the party was hostile to the participation of whites in the struggle. The founding manifesto of the EFF takes the same position. But over the years, the EFF is beginning to glaringly prefer a delimitation to black Africans and coloureds. The perception at the time was that Azapo was racist. In the 1980s, the party moved towards the intersection of class and race as ideological bases of mass mobilisation. Azapo came to believe that class divisions had taken place along racial lines in South Africa because of both capitalism and apartheid. Almost all these issue positions are the current base of the EFF.

\section{The EFF ("post"-apartheid black radicalism)}

The EFF political party was launched on 13 October 2013. Having adopted elements of various radical black liberation movements, the EFF presents itself as a unifier and a reincarnation of the legacy of black resistance. The EFF describes its ideology as "Marxist-Leninist-Fanonian" and also Sankarist, Bikoist and a vanguard of the working class and the poor. The political branding is positioned around the notion of a radical revolution focused on redistribution, economic liberation and empowerment (Horwitz 2016, 40; Founding manifesto 2013). They re-appropriate and perform symbolic black resistance. For example, the EFF re-appropriated signature red berets (from the Black Panther Movement) as struggle accessories while work-man and domestic overalls signal solidarity with working people (Nieftagodien 2015). The revival of (downloadable) struggle songs captures the essence of the revolution. The party invokes spirits of South African and African radical leaders. However, the EFF identifies with the most radical of leaders or elects to remember the most radical times of their leadership. For instance, the EFF wants to recover the history of Mandela as a fighter and commander-inchief of Umkhonto weSizwe (MK). They also chose to remember Winnie Madikizela's legacy as a delinquent of the apartheid government. This rewriting of the political history contrary from the white narrative is an active decolonial tool of epistemic resistance and re-remembrance.

The EFF branded message is that the ANC has abandoned its historical blackness revolution and socialist mandate. The performance of this brand position is in demonstrating to the public the incompetence and corruption of the ruling class. The aim is to unravel the ANCs political hegemony and present it as a crisis, breakdown and a thereat to the people. In taking the advantage of pre-existing grievances, the EFF captured those disgruntled (by unemployment, expensive public services, cut-offs, loadshedding, 
evictions, etc.). According to the EFF, the struggle against the white system is not won. Political liberation is useless without economic freedom. Even '20 years after the attainment of formal political freedom, black people of South Africa still live in absolute mass poverty, are landless, their children have no productive future' (EFF 2013). Twenty-five years on, black people remain landless and at the margins of economic production and participation (EFF 2019). The ANC government reproduces the inequalities and imbalances of the past by not doing much to transform the economy. Instead, their naivety of wanting to be seen as liberal has contributed to uncritical adoption of neo-colonial policies that have stifled development. The catchphrase of "Economic Freedom in Our Lifetime" portrays an urgent mission. Same with the 2019 manifesto, "Our Land, and Our Jobs Now". The urgent emphasis on "Now", according to the 2019 EFF Manifesto, is "informed by the fact that 25 years is a rather long time for any political party to keep making empty promises'.

The EFF issue positions include: (a) land expropriation without compensation, (b) nationalisation of mines, banks and related sectors of the economy - meaning state-owned enterprises must not be privatised (thus an attack on white monopoly capital), (c) capacitating government to self-function without tenders (thus attack on tenderpreneurs), (d) free education, healthcare, houses and sanitation (as a champion of the poor), (e) job creation and good working conditions (thus performative supporting of Marikana), (f) development of the African economy (thus Pan-African nationalism) and (g) corruption-free government. These are issue positions around blackness. The authenticity of these policies is beyond the scope of this chapter. But I aim to explore the reception of these issue positions on Twitter among voters.

Because of his charismatic character, EFF Commander in Chief continues to dominate the mainstream media (Mbete 2016) and social media (Mukhudwana 2020). This is because of his fiery and emotive rhetoric speeches delivered among the masses, not to mention quotable and memeble catchphrases accompanied by dissing the enemy in sometimes funny utterances. As a champion of the people, Julius Malema relies on another political communication style that I have identified as Revolutionary youth radicalisation which mobilises the youth into political positionality and political action within an ideology of "blackness", "us" against "them" (Mukhudwana 2020).

In the beginning EFF has positioned itself within the Left (Horwitz 2016, 65). This position has been uncontested since the fall of the Apartheid government. Even historical, radical left and black revolutionist parties, such as PAC and AZAPO, had moved to the centre if not the right post-1994. However, the rise of populism is dissolving the distinction between rightand left-wing politics. For instance, it is no longer clear whether the EFF is correctly described as lefties politics as it is gradually moving to right-wing ethnic nationalism. 


\section{Methodology}

Using imbizo/Imbadu/Lekgotla/Khoro as an indigenous research methodology, I attempt to answer the research question by decoding the process of the social shaping of blackness in the EFF twitter account. Imbizos can be described as a rhetorical platform used by indigenous communities to resolve community issues and build community cohesion (Mukhudwana 2015). It is a common practice for a chief, headman or any other community leader to convene a community meeting with a view to discussing issues of common concern and interest. The rules and structure of the discussions are set by the communities in question. Khoro/Imbizo as a rhetorical platform can be enacted within an online communicative space to resemble online discussions. It is not the first time that this method has been used within an online environment. Seti-Sonamzi (2019) uses the method within its IsiXhosa version of imbadu. The online communities that go to the EFF twitter page to discuss notions of blackness are similar to the community that goes to the khoro where issues are discussed and negotiated. The point is to draw on the co-creation of knowledge (on this case, notions of blackness) between the political party and its constituents. I argue that khoro expands on phenomenology which does not sufficiently recognise the diversity and the fluidity (negotiability) of knowledge production. As phenomenology is more concerned with the individual and his/her feelings and knowledge, khoro is more concerned with the community of individuals and the rhetoric through which knowledge is created, negotiated and modified. The social shaping of blackness is thus created through this process of negotiation. The social shaping of blackness is essential as blackness is not monolithic or singular. The South African notion of blackness is diverse and thus the positioning of blackness is a perpetual co-created negotiation (now taking place in cyber space). This is what I imply by the term social shaping' of (political) blackness.

The aim of the chapter is to explore the negotiation of blackness as an ideological political branding of the EFF and to conduct a reception analysis of blackness as an ideological political branding by voters on twitter. However, I delimited my analysis to two EFF black issue positions in the year 2020: (1) de Klerk is racist and (2) white monopoly capital. On advanced Twitter search, I punched each of the above issue positions at a time and added EFF as an additional keyword. A qualitative virtual auto-ethnography methodology (khoro) was used and a purposive sample of tweets was selected. Purposive sampling, also known as judgemental sampling, was deemed suitable as it allowed the researcher the ingenuity to select a series of tweets that best represent each issue position (Wagner, Kawulich \& Garner 2012, 93). The period of study is delimited to year 2020 as two of the issue positions (2 and 3) were matters of EFF political performance during SONA 2020 which took place on 13 ruary. The EFF seems to use SONA to set the stage for the performance of their issue positions annually. Certain questions will 
Table 3.1 Analytical questions

\section{Blackness as concept (about voters)}

- What is withheld by the white system (mutual recognition of humanism or the agency of the black to act)?

- Blackness as biology or as lived experience or as performance?

- What black lived experience is identified in the tweet?

- Pan-African vs local blackness - which local blackness?

- Which process of blackness is dominantly discussed? Structural blackness (the pain) or black consciousness (the pride)?

- Enabling self-political identification - how is political blackness used by a voter to identify himself/herself?

\section{Performance of blackness as branding (about EFF)}

- Brand awareness - Are voters aware of the blackness branding of the EFF?

- Brand Image - How do they judge it (good/necessary or bad/useless)?

- Brand authenticity - Do they see it as noble lived black experience or empty performance (populism)?

- Enabling self-political identification - How is $\boldsymbol{E F F}$ brand used by a voter to identify himself/herself?

\section{Black issue positioning (and EFF performances/spectacles around issue)}

- Reception of issue 1 racism de Klerk

- Reception of issue 2 white monopoly capital

guide the selection and the analysis of tweets in each category even though none of the categories are mutually exclusive (they are intertwined). These questions emerged from the conceptual framework, theory and literature. A thematic analysis will follow the categorisation of these questions in addition to outliners found. For future studies, these questions could produce a quantitative analysis on a larger pool of data (Table 3.1).

\section{Findings and discussion}

\section{Reception of issue 1 racism de Klerk}

The selection of the de Klerk issue position by the EFF is pertinent as best able to integrate the racial mood of the country and the EFF's "role" in it. Frederik Willem (FW) de Klerk is the last president of the apartheid government (1989-1996) and the deputy president of SA (1994-1996). Jointly, with first democratic SA president, Nelson Mandela, de Klerk received a Nobel Peace Prize for "giving up" apartheid, releasing Mandela and ushering a universal suffrage inclusive of blacks. Conversely, he is critiqued for complicity in gross human rights violations and massacres during his administration. On 2 ruary 2020, marking 30 years since the unbanning of liberation political parties, de Klerk argued in SABCnews TV interview ${ }^{1}$ that Apartheid was morally wrong but not a crime against humanity: 'Genocide is a crime, apartheid cannot be for instance compared to genocide'... 
'more people died because of black on black violence than apartheid'. Performances: The EFF lobbied for the Peace Price to be revoked along with all his political credentials and privileges. Using aggressive delaying tactics and verbal attacks in parliament during the Sona, they demanded for de Klerk to be removed from chamber labelling with a "racist apartheid denialism". In addition, the EFF laid a charge against him for hate speech. A backlash against de Klerk and the ANC ensued following the aftermath of Sona.

The de Klerk issue looked like a polarising matter but it was not. The majority of voters were unanimous that de Klerk must be chastised and something ought to be done. They were just not convinced that the EFF went about it the right way in making the attack in parliament during SONA. Nonetheless, the division of the issue between two sides was visible. Tension was created along racial lines, with most blacks detesting de Klerk and most whites imposing the acceptance of de Klerk's apology. The white narrative is that the EFF is divisive and predominately vilify white people, @ ElizeVC, 16, 'somebody new to vilify... next week it will be another white person'. @Keith76167969 ( 18) tweeted, 'it's so predictable,EFF refuses to accept de klerk retraction in order to hold centre stage... and pursue their agenda of hate'. The assumption made is that EFF is racist. On the other hand, blacks felt as if their humanity is not mutually recognised when even their mass murder does not qualify as genocide or a crime against humanity, because they still do not qualify the category human.

There were several tweets that indorsed the EFF as the champion of the people against the ANC that abandoned its liberation struggle against apartheid and racism - which still exist in SA. For example, @NicKay ( 16) tweets, 'The ANC was protecting de Klerk, DA was protecting Ramaphosa, EFF was protecting people of South Africa. SONA 2020'. The tweet had $1.1 \mathrm{~K}$ likes. This is an ideological success for the EFF because it paints Ramaphosa and the ANC as sell-outs protected by the white system. In such case, no one is left to defend black people, but the EFF. @Nathi_Mfokajobe ( 18) tweets, 'As far as they were playing their politics, deep down I appreciate EFF for embarrassing de Klerk in front of the nation while ANC was kissing him'. This is a similar quote in the category of a backlash against the now useless apartheid apologist ANC. However, this tweet resembles another category of tweets which indicate that voters are aware of the theatrics of the EFF as political performance. For example, @ HonourableHloni tweets, 'the same people who called EFF populist for demanding de klerk's removal from parliament are applauding the American Bar Association for cancelling his talk on law and racism'.

The agreement among voters is that EFF's theatrical performances, though labelled populist, are effective in not only setting the national agenda, but also enforcing an experiential political reform or effecting other consequence regarding the issue. An additional tweet is, 'due to EFF characteristically known for militant, fearless and radical character - the nation was rudely forced to have a conversation about institutional racism, especially 
against white supremacists' (@Sam_Matiase, 16). These performances are deemed successful where others have failed to bring the black agenda to light and equally pressure for its resolution. @MelusiMaposa ( 16) tweets, 'does anyone still doubt the EFF's ability to set the national agenda? 2020 wasn't the first time de Klerk peddled his apartheid denialism. It's just the first time that EFF made him the focal point'. The PAC has brought this issue up on a number of occasions but did not successfully succumb it to the national discourse. Perhaps because fewer voters comprehend the PAC's current ideological branding position. Another issue performed by the EFF during the 2020 Sona is the WMC.

\section{Reception of issue 2 white monopoly capital}

The selection of the issue position of White Monopoly Capital (WMC) contributes towards highlighting the economic emancipation agenda of the EFF. So powerful is the catchphrase popularised by Bell Pottinger that it resulted in its own Wikipedia page which defines it 'as a controversial South African phrase used in contemporary political discourse to describe the continued economic domination of whites in post-apartheid SA'. It is powerfully posited as the real reason blacks remain systematically oppressed and enslaved to a marginal lived experience. Consider for example a black woman having to withstand inhuman domestic employment in order to pay rent, pay school fees and feed kids. Therefore, WMC is directly linked to the capacity of blacks to act (agency) in an anti-black capitalist system. What is confusing in the blackness branding is that this positioning implicates both the white system and selected blacks as agents of that system. Performance: EFF calls on the African continent to reject the WMC puppet Trevor Manuel as AU Envoy on a statement dated 13 April 2020. The EFF organised a well-attended \#EFFEskomMarch with the message that Pravin must go, Eskom must not be privatised and load shedding must fall.

The issue positioning of WMC is intricately positioned as the performance of various categories of players. One of such is the ANC government, within which President Ramaphosa and Pravin Gordhan, Minister of Public Enterprise, are the main villains. On the manifesto to Consultation Assembly, Malema said, 'When we formed the EFF, we knew that the will not allow for the nationalisation of the strategic sectors'. For this reason, "we have decided to go against Pravin". Another strong message went to Cyril Ramaphosa upon his election to the national assembly as president: 'we know your proximity to Oppenheimers. We've not elected Oppenheimers here...we are warning you president, we've not elected the Ruperts... once you listen to white monopoly capital, you must know that you are likely not to finish your term'. This is interesting because the EFF believe they have the power to inaugurate and topple SA presidents. The other agent of WMC in SA according to the EFF is STRATCOM media syndicates, who are mainly white-owned media responsible for publishing anti-black racism in addition to discrediting the EFF and its leadership. @naledimashishi tweets, 'So basically any journalist 
who publishes any article critical of EFF is now STRATCOM. EFF leadership cannot be criticized... if they are, it's a conspiracy by WMC'. STRATCOM was an organ of the Apartheid state propaganda. The third accused agent of WMC is white farmers who are unduly holding on to the land. For instance, Zukowski (2017) postulated that the discourse of land reform has been radicalised by the EFF in a race-based populist narrative of land expropriation without compensation. @SiyaNdlovu91 (Apr 16) tweets, 'EFF policies are strong on WMC...there is a pillar of land expropriation without compensation. It is not a compromise in the culture of the EFF'.

The issue of WMC among the blacks is polarised with others seeing EFF as a vanguard of the people saving them from expensive privatisation leading to the poverty of the poor against those who see it as an EFF agenda to secure corruptive looting of state agents through underhanded tenders. On one side stands proponents. @MzilikaziKADON1 (March 3) tweets, 'Ramaphosa said with his own mouth today that he is interested in selling some parts of Eskom. If EFF did not expose him with Jamnandas, Eskom as a whole was gone to the biggest WMC bidder'. And on the other side stands opponents. 'We know that Malema is using his EFF to fight his personal battle with Pravin in the name of fighting WMC'. Another voters' backlash against the issue position of white monopoly capital is with regard to EFF leaders' own proximity to capitalism and its aesthetics. @ chestermissing (May 10) tweets, 'Andile says the EFF represents white monopoly capital. Is he talking about comrade Breitling, Johnny Walker and Louis Vuitton?'. Even further critique refers to EFF's coalition with the Democratic Alliance in provincial and local government. @Vuyo17 (July 28) tweets, 'The EFF votes were sold to the racist DA. EFF is just a WMC scam to steal black votes'. What these critiques have in common is the dichotomy between the EFF performance of blackness as a brand which seems contrary to its lived/political experience. This brings into question the authenticity of the brand.

\section{The societal reception of blackness as political branding}

The ideology of the EFF is often put into question regarding blackness and class. For example, @Brandaan Huigen (28) tweets, 'So the EFF does have an issue with luxury lifestyles? Always thought it was ok to be Gucci-socialist. Maybe Sankara has finally become an inspiration'. This tweet reinforces the stereotype of associating authentic blackness with a lower class and frugality. Even though criticising the EFF, this voter is conscious of the EFF's ideology around class and blackness. Thus, even those who attack the EFF for racism are brand aware of its blackness.

There is general societal acceptance and understanding of blackness as political branding, what is frowned upon is the abusive utility of the emotive realities of blackness (the black condition) for cheap political capital. The weaponisation of blackness as a political tool. One tweet states, 'EFF doesn't care about your blackness. They use it for votes and a better life for themselves' (@Unathi_Kwaza, May 22)._Therefore, the genuine interest and care of the 
black masses become the authenticity marker leading to the legitimacy of the party. In addition, the claiming of the blackness branding is also used by voters to police the EFF's behaviour towards the black population. As the case has been with the defaming of black lawyers as incompetent. This is a unique tool for accountability.

Voters' acknowledgement that the black population in SA is not monolithic grounds the critique against the positioning of the EFF as the sole custodian of blackness. For example, @Makgatho18 (Oct 22) laments that most fighter's intellectual lethargy is indicated by the thinking that EFF has sole proprietorship of blackness and that any ideology that deviates from EFF's is racist. 'The minute you disagree with the views of the EFF members as a black person you are called coconut, sell out, house-nigger etc. Like they are the custodian of blackness' (@Sakhilemngadi,Sep 20).

The EFF is seen by proponent tweets as fighting structural blackness and cultivating black agency. As the case is with, @Ketso_4LIFE (Oct 11). The EFF 'teach us to be proud of our blackness, to be proud of our history and culture as Africans'. On the contrary, there were several tweets expressing discontent to what they consider to be intolerant racist behaviour suggestive of racial radicalism.

\section{Conclusion}

In this chapter, I attempted to observe the extent to which voters are conscious of blackness as the EFF political branding/strategy/ideology and to explore the general societal acceptance of the branding strategy. I can safely conclude that voters are aware of the blackness branding position of the EFF. The division is with regard to the brand image (favourable or negative). The brand image differed, issue by issue. Whereas issue 1 garnered a widely positive image, issue 2 was polarised. While the de Klerk issue position had capacity to tremble the rainbow nation as a myth of reconciliation in "post-apartheid" South Africa, the WMC positioning weakened the very concept of "post-apartheid" SA as the lived experiences of blacks remain unchanged, economically enslaved to the zones of non-being. There is general societal acceptance and understanding of blackness as political branding, what is frowned upon is the weaponisation of blackness as a political tool. A broad quantitative study could better validate this preliminary finding. Future studies could also look into \#PutSouthAfricansFirst in order to decipher the reception of the EFF's Pan-Africanist concept of blackness which is inclusive of all Africans contrary to Biko's concept of blackness as all people subjected to apartheid in SA (local) which exclude immigrant African blacks who did not suffer anti-black racism in SA. This complexity deserves a full review. I would conclude this chapter by stealing a well-posited tweet by @OwaseMzantsi (20 Nov 19), 'Politics is FICTION, politicians are ACTORS in a soapy called "string then along for POWER". Like all fiction, they have to adhere to a script, a narrative they have to push'. 


\section{Note}

$1 \mathrm{https} / / / \mathrm{ww}$ w.youtube.com/watch?v=VBE844vDkx4\&t=1339s

\section{References}

Abertazzi, D \& McDonell, D. (2008). Twenty-First Century Populism: The Spectre of Western Europe Democracy. United Kingdom. Palgrave Macmillan.

Azapo prides itself on paving way for new parties. 2 May 2019. SABC News www. sabcnews.com/sabcnews/azapo-prides-itself-on-paving-way-for-new-parties/

Biko, S. [1978] 2017. I write what I like. The 40th anniversary edition. South Africa: Picador Africa.

Bourdieu, P. 1986. The forms of capital. In Richardson, J. (Ed). Handbook of Theory for the Sociology of Education (pp 241-258). Westport, CT: Greenwood.

Calmore, J.O. 2005. Whiteness as audition and blackness as performance: Status protest from margin. Washington University Journal of Law \& Policy, 18(6): 99-128.

Canham, H., \& Williams, R. 2017. Being black, middle class and the object of two gazes. Ethnicities, 17(1): 23-46.

Collins, P.H. 2006. New commodities, new consumers. Ethnicities, 6(3): 297-317.

Costa Vargas, J.H. 2006. Black radical becoming: The politics of identification in permanent transformation. Critical Sociology, 32(2-3): 475-500.

Dean, D., Croft, R., \& Pich, V. 2015. Toward a conceptual framework of emotional relationship marketing: An examination of two UK political parties. Journal of Political Marketing, 14(2): 19-34.

Dei, G.S. 2018. "Black like me": Reframing blackness for decolonial politics. Educational Studies: A Journal of the American Educational Studies Association, 54(2): $117-142$.

Economic Freedom Fighters Founding Manifesto: Radical movement towards economic freedom in our lifetime. Adopted by the Economic Freedom Fighters National Assembly on What is to be Done: 26 to 27 July 2013. Available: https:// effonline.org/wp-content/uploads/2019/07/Founding-Manifesto.pdf.

Economic Freedom Fighters 2019 Election Manifesto. 2019. EFF Online (online.), 6 May. Available: https://effonline.org/wp-content/uploads/2019/07/2019EFF-MANIFESTO-FINAL-1.pdf [23 May 2019].

Epstein, B. 2018. Biko on Non-white and black: Improving social reality. In G. Hull (Ed.), Debating African philosophy: Perspectives on identity, decolonial ethics and comparative philosophy (pp. 97-117). New York: Routledge.

Fanon, F. [1952] 2008. Black skin, white masks. Canada: Editions du Seuil.

Forster, D.A. 2019. State theology and the political populism? A Kairos critique of religious populism in South Africa. Journal of Church and State, 62(2): 316-333.

Fuller, J. 2010. Branding blackness on US cable television. Media, Culture and Society, 32(2): 285-305.

Gordon, L. 2015. What Fanon said: A philosophical introduction to his life and thought. New York: Fordham University Press.

Grimmer, M., \& Grube, D.C. 2017. Political branding: A consumer perspective on Australian political parties. Party Politics, XX(X): 1-14.Horwitz, D. 2016. The role of political branding in the success of the Economic Freedom Fighters (EFF). A minor dissertation submitted in fulfilment of the requirement for the award 
of the degree of Masters of Social Science: Political Communication. Faculty of Humanities. University of Cape Town.

Johnson, E.P. 2003. Appropriating blackness: Performance and the politics of authenticity. Durham, NC: Duke University Press.

Mbete, S. 2016. Economic freedom fighters' debut in the municipal elections. Journal of Public Administration, 51(3): 596-614.

Melber, H. 2018. Populism in Southern Africa under liberation movements as governments. Review of African Political Economy, 45(158): 678-686.

Milewicz, C.M., \& Milewicz, M.C. 2014. The branding of candidates and parties: The U.S news media and the legitimization of a new political term. Journal of Political Marketing, 13(x): 233-263.

Mukhudwana, R.F., 2015, 'Investigating communication management by government in the Kwa-Zulu Natal Province in South Africa', PhD thesis, University of Pretoria.

Mukhudwana, R.F. 2020. \#Zuma must fall this ruary: Homophily on the echo-chambers of political leaders' Twitter accounts. In M. Ndlela and W. Mano (Eds.), Social Media and Elections in Africa, (Vol. 2, pp 175-202). Cham: Palgrave Macmillan.

Nieftagodien, N. 2015. Economic freedom fighters and the politics of memory and forgetting. The South Atlantic Quarterly, 114(2): 447-456.

O'Reilly, D. 2006. Commentary: Branding ideology. Marketing Theory, 6(2): 2630271.Pich, C., \& Dean, D. 2015. Political branding: Sense of identity or identity crisis? An investigation of the transfer potential of the brand identity prism to the UK conservative party. Journal of Marketing Management, 31(11-12): 1353-1378.

Serazio, M. 2017. Branding politics: Emotion, authenticity, and the marketing culture of American political communication. Journal of Consumer Culture, 17(2): $225-241$.

Seti, V. 2019. On Blackness: The role and positionality of Black Public Intellectuals in Post-94 South Africa. Thesis submitted in accordance with the requirements of the degree of Doctor of Philosophy. University of South Africa.

Sithole, J. 2011. Inkatha freedom party - national freedom party dynamics in the KwaZulu-Natal Province. Journal of Public Administration, 46(3): 1169-1181.

Sithole, T. (2016). The Concept of the Black Subject in Fanon. Journal of Black Studies, 47(1), 24-40.

Sithole, T. (2016). The Concept of the Black Subject in Fanon. Journal of Black Studies, 47(1), 24-40.

Stevens, G., Bell, D., Sonn, C.C., Canham, H \& Clennon, O. 2017. Transnational perspectives on Black subjectivity. South African Journal of Psychology, 47(4) 459-469.

Wagner, C, Kawulich, B \& Garner, M. 2012. Doing social research: a global context. South African Edition. Berkshire: McGraw Hill Higher Education.

Walters R. 2007. Barack Obama and the politics of blackness. Journal of Black Studies, 38(1):7-29.

Wa Thiong'o, N. 2012. 10th Annual Africa Day Memorial Lecture, delivered at the University of the Free State, South Africa, May 25, 2012.

Wright, H.K. 2016. Stuart Hall's relevance for the study of African blackness. International Journal of Cultural Studies, 19(1): 85-99.

Zukowski, A. 2017. Land reform in the republic of South Africa: Social justice or populism? Werkwinkel, 12(1): 71-84. 


\section{Part II}

\section{Film and photography as activism}

Decolonisation and performance 

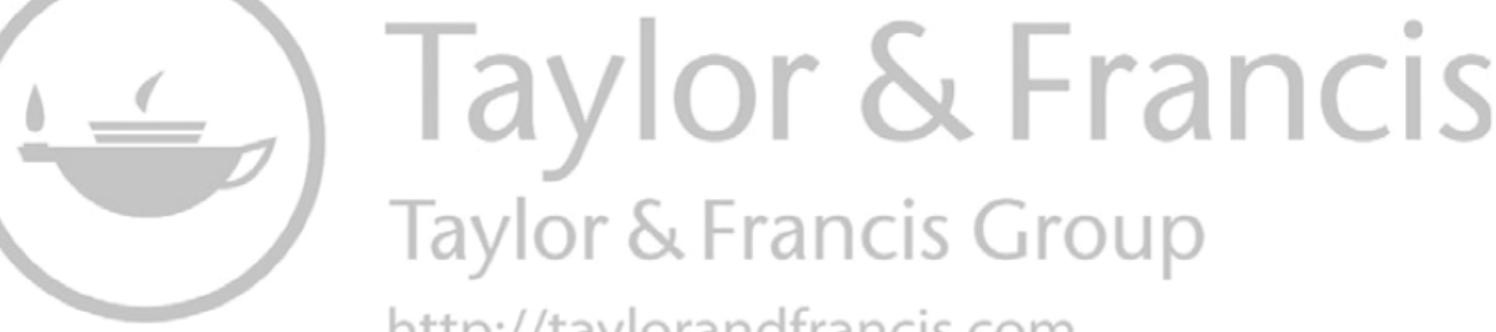

http://taylorandfrancis.com 


\title{
4 Zanele Muholi's work as decolonisation and political communication
}

\author{
Beschara Karam
}

\section{Introduction}

Everything about Muholi's art is political: the portraits, the recording of testimonies, the photographing of trauma, as well as the representation of contexts, the lived realities, and the apartheid/colonial histories which she depicts. As Muholi (cited in Abel-Hirsch 2020) has stated, 'I use my own body and face because the work is meant to be confrontational, both personal and political at the same time' and

Race, class and privilege are intimately connected to wealth, access and exclusion. The world of art is not isolated from all of this - it is informed by the time it is in as well as the context in which it operates and continues to operate.

Muholi questions what it means to be an "artivist" (Goldsmid \& Muholi 2010) in the repressive, violent socio-political context from which they was born and grew up in - the height of apartheid. Where her mother served a White family for more than 40 years. She challenges the massive gap between the South African legislation and lived realities. Muholi wants to reclaim of the lives of Black and trans queers living in South Africa. She chooses to represent, challenge, and memorialise the enduring legacy of apartheid and colonialism which continue to affect the lives of the Black LGBTQIA+ South Africans. Muholi is responding by making the invisible visible, depicting the unrepresentable, in a political landscape that still favours White lives over Black lives. Muholi does this through her combined artistic and community engagement work. Zanele Muholi's ${ }^{1}$ film Difficult Love (Goldsmid \& Muholi 2020) reactivates memory as a way of negotiating the present, to generate a historical and political consciousness, where the evidence of recording testimony is not necessarily to preserve history for posterity but to 'tell their stories to the public, to be listened to, and to be acknowledged' (Goldsmid \& Muholi 2010). Their body of work disrupts and challenges politics and gender: the heteropatriarchal, colonial and post-colonial gaze; apartheid and its legacies. For instance, 
not only is Difficult Love a "site of memory" or an artefact of memory, wherein individuals not only recount their traumatic experiences, but a political act as it documents Muholi's work in local communities. For example, Muholi takes in groups from their community to view their works, exhibited in museums or art galleries: the gallery becomes a structure of memorialisation wherein their works engage both the individual and the community both separately and mutually in a process of conversation and discourse - displacing and challenging the reification and gentrification of such spaces. But more importantly it serves as a form of political intervention: giving the marginalised a view into a "privileged" geographical and mental place, thereby decolonising it and de-reifying it. In addition, the film documents how they give cameras to disenfranchised subalterns (lesbians and trans, most especially). Muholi teaches them how to use a camera and then prints their photographs. Once again, Muholi has taken a very gentrified and elitist art form and decolonised it, making it accessible, but most significantly, allowing the photographs to tell a story(ies). Muholi and Goldsmid's film, Muholi's community engagement projects, and their own photographic works are significant in that they raise social and historical consciousness to examine cultural issues of experience, traumatas, memory(ies), sexualit(ies), identity, colonialism, apartheid, heteropatriarchy, and representation. With themes of power, subjugation, violence, femicide, and corrective rape. Goldsmid and Muholi's (2010) film and Muholi's photographs are a unique "politics of perception" (Wallis \& Duggan 2011:2) and they help render accessible the shattered experiences of lesbians and trans' post-memories, traumatas, apartheid, post/colonialism, and history. Thus, in this chapter I argue that Muholi's works are therefore a form of political communication and serve as examples of disruptive performance and decolonisation. As I understand it, the underlining ethos of decolonialisation has two essential tenets: humanity and social justice. So too does the work of artivist Muholi. In addition, their works document political issues which, through their art and activism, they communicate to the audience and communities, communicating about politics: gender, poverty, and, class in a South African post-apartheid landscape. This chapter will make use of Paolo Freire's work as well as that of bell hooks to support the argument. The chapter also looks at secondary witnessing and historical trauma, and the role Muholi's work plays in representing, memorialising, and sharing these traumas. The chapter only focuses on their film Difficult Love; although the film itself references much of Muholi's varied and insightful works, as well as their activism.

\section{The film: Difficult Love (2010)}

Difficult Love was produced by Peter Goldsmid and co-directed by Zanele Muholi and Peter Goldsmid. It was commissioned by the South African Broadcasting Corporation (henceforth, SABC) ${ }^{2}$ in 2010. Peter Goldsmid, 
an award-winning film and television director and producer, has worked with both SABC 1 and SABC 2; and he is most well known for his television series Justice for All (1999-2006), Glas-kasteel (1993), and Riemvasmaak (2008). His critically acclaimed film directorial debut was The Road to Mecca (1991), starring Academy Award winner Kathy Bates. Although both Muholi and Goldsmid co-direct this film, and technically this is their film, the film really is about Muholi - their works, their identity, and their history, as they state in the very beginning: "this is me, presenting myself". Difficult Love has been screened at many film festivals around the world, including the International Film Festival on Human Rights in late 2013, and it has won several awards. ${ }^{3}$

The film is a comprehensive compilation not only of Muholi's work but also of the issues and controversies that have surrounded their work. It is, from the outset, in and of itself, a form of activism: beginning with a photoplay of Muholi's photographs and their introduction of theirself to the viewer as an "artivist", or gender activist, first and foremost. Muholi defines their own photography as "radical and political" (Goldsmid \& Muholi 2010). The film not only documents Muholi's work and that of some of their subjects, but also presents the viewer with the overt connotations of their work: a challenge to patriarchy, heteronormativity, the nuclear family, trauma, memorialisation, historical consciousness and colonialism. Difficult Love also challenges. The film focuses on Muholi's own identity as Black, lesbian but also their identity as ballroom dancer, sister, "grandmother", partner, tomboy, beauty pageant contestant, and photographer. Muholi is unbearably sad when talking of the passing of their mother. What is of particular interest is that no-where is their father ever mentioned.

At a secondary level, are the more insidious themes that this documentary contests and exposes: issues of race, poverty and homelessness, the wounds and scars of apartheid, class, and even visual illiteracy. The film offers a socio-economic and ideological critique of South Africa.

Muholi's erudite deconstruction of their own work, as well as their own identity is thought-provoking. One of the most stunning set of photographs (triptych) is the image of Muholi lying with their ex-partner on top of Muholi, from their series Caitlin \& I (2009). Muholi describes the photograph as one of racist ideology and slavery: they put their ex-partner on top of them because according to Muholi, 'we feel like slaves in our relationships' (Goldsmid \& Muholi 2010). However, it does raise an interesting observation of Muholi's work: most photographers let their works speak for themselves. They leave the viewer to interpret the photographs, often presented in sparse exhibitions. Not so with Muholi. From the very outset of this documentary, Muholi is always at great pains to explain the context and background of their work.

Some of the photographic and community activism that features within Difficult Love includes Trans(figures) (2010-2011) (transgender individuals in various poses) and Ordeal (2003) (a close-up black-and-white figure 
wringing out a cloth from an enamel basin). The implication, from the title of the photograph, is that the individual is washing herself after a traumatic event. Caitlin \& I (2009): Muholi and their ex-girlfriend, Caitlin. A triptych depicting Caitlin on top of Muholi facing towards the ceiling, while Muholi lies of her arms, bed downwards. Both appear completely naked. Faces and Phases (2006-ongoing): Black and White portraiture series. Where individuals' diverse identities and individualities are central: close-up portraits of Black lesbians, transgender, and gender non-conforming individuals (from South Africa and elsewhere). In this series, sometimes a portrait is accompanied by the testimony of the individual in the portrait: documenting and archiving the social and sexual injustices they have endured. Thus, providing historical, political, and personal context of those photographed for history and memorialisation. The participants stare directly into the camera lens. This series is dedicated to Muholi's friend, Ms Busisiwe Sigasa (an activist, and poet, who died at the age of 25 from AIDS-related health complications, which she contracted after being correctively raped). For me, the title of her series "Faces" refers to the individuals faces - their stance, expressions dress - while "Phases" indicates a "transition" of gender and sexuality - from being unrepresentable to being representable, transitioning from being invisible to being visible, from being unheard to being heard (where testimony accompanies the portrait), from being unworthy to being worthy. I believe these portraits represent a pride, and an acknowledgement of their beings, their socio-political realities, their lived realities, their different contexts, and the fact that they matter. 'Collectively, the portraits become an act of visual activism, the photographer's response to the violation, rape and murder or innocents because of their sexualities and ethnicities'(Brodie/Stevenson curatorial notes 2009). Aftermath (2004): a close-up of a Black woman, from the waist to just above the knees. Wearing Jockey underpants, hands folded in front of her pudenda, with her right thigh covered in a massive scar, from where a wound has been inflicted and sewed up, the stitches leaving dotted, raised scars on either side of the thighlength slash. The scars, as well as the protective hands, speaks of trauma, of strength (survival) and sensitivity (in the intimate portrayal of the hands protecting her sex(uality)). Being (2008) depicts Black South African lesbian couples and their domestic lives. Massa and Mina $(h)$ (2008) shows a photographic project that is based on the life of Muholi's mother who worked as a domestic worker for the same family for 42 years. The colour photographs feature Muholi: sometimes as the "maid" and sometimes as the "madam", in different domestic scenes. Muholi role plays within it. Muholi has said that this series is meant to acknowledge domestic workers wherever they may be (Brodie/Stevenson curatorial notes 2009).

The community engagement work that features is "Ikanyiso" (2009) (meaning "illuminate" in Zulu), which is a non-profit organisation whereby Muholi trains individuals to photograph and print their images, a form of queer visual activism - the teaching of visual literacy. ${ }^{4}$ The film also 
mentions Forum for the Empowerment of Women (FEW), which Muholi co-founded in 2002: a safe space and place for Black women to meet and organise their political and social activism.

\section{Decolonial studies/decolonisation}

The seminal authors of decoloniality - Ramón Grosfoguel (2011), Enrique Dussel (1977), Aníbal Quijano (1991, 2000), and Walter Mignolo (1995, 2000) - are writing about the 'subalternalized racial/ethnic/sexual spaces and bodies' (Grosfoguel 2011:2; cf. Grosfoguel 2007). In doing so, they have highlighted that South Africa, as a post-colonial country, is still heteropatriarchal capitalist, hierarchical, racialised, classist, gentrified, and imperialist (Ndlovu-Gatsheni 2013). South Africa is still entrenched with insidious colonial, institutional power interactions and entanglements. It is thus essential that such scholars, as well as various contemporary cultural texts, challenge this "colonial power matrix" (Quijano 1991, 2000). This power matrix includes reified gender hierarchies, local racialised divisions of class and labour, aesthetic hierarchies, and epistemic hierarchies that preface, or privilege, White over Black. Academic Quijano expounds on his concept by expressing that it is also an "organising principle" that involves exploitation and domination (1991). Furthermore, his concept is intrinsic to politics, socio-economics, institutions, and even epistemologically (Quijano 1991, 2000). This "colonial power matrix" ("patron de poder colonial") or "coloniality of power" is still intrinsic to South Africa. The film, Difficult Love, challenges this "colonial power matrix", by providing a reflexive "decolonial critique" that acknowledges the silenced, marginalised, and subalternised (most especially the victims of homophobia and transphobia, poverty and social engineering). Difficult Love questions the "colonial power matrix" that permeates South Africa at every level by screening the continued apartheid of class, gender, and economics.

\section{bell hooks}

Drawing on the work of bell hooks (1995), Art on My Mind: Visual Politics, this chapter positions Difficult Love as a film that 'constitutes one of the rare locations where acts of transcendence can take place and have a wide-ranging transformative impact' (1995:8). As such, this film is a revolution in viewing:

we struggle against forces of domination and move toward the invention of the decolonized self, we must set our imaginations free. Acknowledging that we have been and are colonized both in our minds and in our imaginations, we begin to understand the need for promoting and celebrating creative expression. 
This film and the works of Muholi cited within, along with testimonials, are indeed a critical "intervention": they are sites of visual contestation; cinematic and photographic aesthetics, with personal (subaltern) narratives that re-remember; they reclaim history(ies), ancestry(ies), and identity(ies). In doing so, the film and the artwork it references decolonises both the mind and the imagination: asking the audience to transcend gender, politics, and socio-economics. Muholi's collective works have motifs of queerness, history and ancestry (Muholi's own and that of South Africa), memory, trauma, colonisation, feminism, masculinity, trans, identity, and apartheid (and post-apartheid). Muholi's film and art transcend and transgress the boundaries of what bell hooks terms "visual politics" (1995:4), which include race, culture, and gender. In doing so, this collective artwork and film help set our imaginations free: they are self-reflexive, and they offer different ways of seeing and imagining the past, the present, and the future. For instance in the series Massa and Mina(h), Muholi's role plays between madam and domestic worker: an effort to reimagine the past, what it was like being a domestic worker under apartheid, as her mother was. And re-imagining what it is like to be a domestic worker now: a White domestic worker working for a Black madam.

bell hooks also argues that not only visual aesthetics, in this case the photographs and film, are a site of contestation and struggle, but they collectively "nurture the spirit and provide ways of rethinking and healing psychic wounds inflicted by assault from the forces of imperialist, racist, and sexist domination' (1995:4-5). For example, the photographic series Massa and Mina(h) addresses psychic and historical wounds - rethinking and re-imagining (colonial) history but also the physical and psychical wounds of everyday subjugation; lack of independence. Being a domestic worker during apartheid meant having to abide by the policies of the nationalist government, such as the Pass Laws and social engineering. Only one Black person was allowed to stay at a White domicile at any one time, after curfew. This meant that Black mothers who worked as domestic workers had to leave their own children to be raised in the community, or an extended family, and they rarely saw their own children. While simultaneously raising the White children of the family they were working for. Muholi also addresses physical and psychical wounds by directly inhabiting the spaces and contexts of the subalterns, the lesbians and trans individuals who have no homes or livelihoods, which, while they attest is the result of an inherited violence of apartheid, shows no sight of change in the "new" dispensation, the so-called post-apartheid era. I refer here to the project where Muholi gives cameras and photography lessons to individuals in the communities (townships in most cases but also make-shift "communities" of shacks; and even those who are homeless, such as the couple who live under a bridge). Here, Muholi not only teaches a skill, but encourages individuals to see themselves (through the lens of the camera) as worthwhile and to have some sense of self-esteem. Most especially those who have suffered from aggressive 
patriarchy and sex crimes for their queerness. Muholi also encourages them to acknowledge that they belong, and they have a right to existence. While Muholi's documented project is empowering, the result is a community(ies) and individuals who have to confront their pain, and physical and psychical traumata as a direct result of both colonial and post-colonial violence. Whether it be corrective rape, thrown out of the home for "coming out", or losing their livelihood for being gay.

Through several motifs, the themes of established power and authority are explored by Muholi, both literally and obliquely. These are the political, social, economic, and gender motifs. The film, thus, challenges the status quo, and disrupts it as a form of "epistemic disobedience" (Mignolo 2011). The film, and Muholi, strongly suggests that a destabilisation or epistemic disobedience of the status quo is called for: a decolonisation of the mind. The film and the photographs therefore work as a site of possibility, and an agent of change, but the socio-realities of those living with alternative sexual and gender lives are devastating to watch, despite Muholi giving the individuals a voice/s.

Returning to bell hooks, hooks also refers to the 'representation as a location of contestation' (1995:4). Keeping Muholi's film and photographs in mind, "contestation" relates to the contesting of colonial and apartheid history and post-colonial and post-apartheid contexts. In other words, Muholi questions why things have not yet changed for the majority of Black lives, with the "new" government. Why are the violence, patriarchy, and sociorealities of the subalterns unchanging? However, representation is also a way to decolonise the mind and the imagination by re-imagining, reclaiming, and remembering (worlds and identities of multiverses). And so not only does Muholi give "life" to these stories; they claim them for eternity, as is the nature of photography, but they encourage the audience to engage with these stories and motifs. Muholi wants us, the audience, to imagine a world without rape, misogyny, queericide, but also one where a country and a community are truly post-colonial and the legacies of our haunted histories have been banished. Where policies of the government for freedom of sexual expression are upheld and enforced.

Another element of decolonisation to be considered when viewing Difficult Love is that of context. Where the lived realities and experiences of different individuals are acknowledged and where empathy is reflected. Both are prevalent in the film which emphasises the context, identities, and socio-political realities of diverse cultures: and is ultimately a rallying cry for empathy, compassion, social justice, and inclusion.

bell hooks also writes that 'representation is a crucial location of struggle for any exploited and oppressed people asserting subjectivity and decolonization of the mind' (1995:3). For Muholi, film and, by extension, photography are encounters with the visual that bear witness to, and work to signify and depict 'the silence and erasures of the past' (1995:3). Again, this speaks to Muholi's interrogation of both the past and the present. Muholi also 
bears witness to different traumas as a result of patriarchy and misogyny, and they demand the recognition of the realities of the present: the inherited legacies of the past that haunt the present. Consider, for example, White lesbians who have the freedom to enact their lives in the open if they so choose to without the fear of corrective rape or brutal beatings. Unlike their equivalents in Black communities, where to "come out" is to invite violence and even death. This is not to say that White lesbians live without any discrimination, but it is a rarity, and if it is the case, they have legal recourse, if they so choose, whereas their Black counterparts cannot afford such remedies in the majority of cases.

The film also bears witness to the apartheid and colonial and political history and memory of African identity and culture. Included here are motifs of the perpetuation of imperialist socio-political powers and physical structures. For instance, Muholi visits the home where their mother worked as a domestic worker in a middle-class White area (evidence of apartheid's social engineering). Muholi seems so fond of the family which patronised them. Muholi, interestingly, feels no anger towards the patronage and is very grateful to that family. Even the fact that Muholi includes them in this very personal film and narrative of theirs is testament to a (shared) fondness. After all, Muholi tends to exclude their father completely. Revisiting the family their mother worked for does bring up the past: how Whites often took it upon themselves to purchase school uniforms and books for the children of their domestic workers. (Although this shows a kindness, domestic workers worked without any rights or unions and were at the mercy of their employers.) So too was in the case of Muholi and their "second" White family.

\section{Paolo Freire}

Now we turn to the work of Paolo Freire and his idea of "consciousness raising" (1970), or critical consciousness, or "conscientization" (conscientização), which is the noting/uncovering of social and political contradictions and acting against oppression.

This concept is used here in order to understand and explain how cinema has the potential to develop, provide, and facilitate political expression: that film politicises consciousness, and while I argue here that Difficult Love also politicises thought, it encourages a political consciousness. In that it raises questions not only about the inheritance of apartheid but also about our current government: for example, why, when South Africa has the most progressive constitution, ${ }^{5}$ is there a conspiracy of silence surrounding corrective rape and violence against lesbians in the Black community (van der Schyff 2015, 2018)? As one man says in the film Difficult Love "rape is rape" it does not matter if that woman is a lesbian or not. But it does matter. Why, in one of the most democratic countries in the world, is "corrective rape" considered to be a purely South African phenomenon? (Wood 2013:297). Not only does the film, and Muholi's photographs represented within, raise 
a "political consciousness" about violence against women, most especially Black women, lesbians and trans, but also about apartheid and colonialism. Julia Kristeva (2002:435) writes of history: 'What makes sense today is not the future... but revolt: that is, the questioning and displacement of the past. The future, if it exists, depends on it'. Muholi challenges the past by questioning apartheid's classist and imperialist legacies, and the "new" government. Difficult Love also challenges the conspiracy of silence about corrective rape; we see this when the community gets together to speak about their concerns, interviewee Funeka Soldaat features. They were brutally raped and stabbed a total of 11 times: those who are "correctively" raped choose not to report it as they would be accused of "lying". Two of Muholi's comments bear repeating: "the wounds of the past keep on opening" and "I'm breaking". Muholi's film, her photographic series, raises consciousness not only about political and social justice but also about traumata, which brings us to the concept of "secondary trauma".

\section{Secondary trauma}

In her book Unclaimed Experience: Trauma, Narrative, and History (1996:11), Cathy Caruth argues that a textualist approach (one which insists that all reference is indirect) can afford us unique access to history:

Through the notion of trauma... we can understand that a rethinking of reference is aimed not at eliminating history but at resituating it in our understanding, that is, at precisely permitting history to arise where immediate understanding may not.

It is therefore important to represent trauma, as Muholi does. Caruth also argues that history as being inherently traumatic, and trauma as an overwhelming experience that resists integration and expression. No one can deny that apartheid and colonial histories are not written with trauma. And the legacies of those traumas are still present today. Furthermore, according to Caruth, conjoining a Freudian view of trauma with a deconstructive "vigilance" regarding the indeterminacies of representation in the analysis of filmic and photographic texts that bear witness to traumatic histories can grant us an insightful mode of access to extreme and "unrepresentable" events and experiences that challenge both understanding and representation. Caruth adds that 'history, like trauma, is never simply one's own, ... history is precisely the way we are implicated in each other's traumas' (1996:24). In a catastrophic colonial, or so-called post-colonial) age such as ours, Caruth writes elsewhere, 'trauma itself may provide the very link between cultures' (Caruth 1995:11). With trauma forming a bridge between disparate historical experiences, so the argument goes, listening to the trauma of another can contribute to cross-cultural solidarity and to the creation of new forms of community. I would like to argue that it does, most especially 
where South Africa is concerned. Drawing from Caruth's theory, I now look at Muholi's work specifically as a documentary film that bears witness to the unrepresentable traumatic of those Black lesbians and trans individuals who have suffered psychologically, physically, or sadly lost their lives. My second exposition deals with Muholi's work as trauma art and an exemplification of "vicarious, or secondary, trauma". Cathy Caruth defined trauma in her seminal work, as 'an overwhelming experience of sudden or catastrophic events in which the response to the event [is] ... often delayed, uncontrolled [and] repetitive' (1996:11). While collective traumata are those traumata experienced as a group, community, or culture. Apartheid and colonisation, homophobia, transphobia are traumatas experienced by both the individual and the collective. Near the beginning of the film, Muholi films two women, Petra and Praline, who were thrown out of a homeless shelter because of their love for one another, and are now living under a bridge in horrendous conditions. Muholi states that they wish they could do more for them, they start to cry. Later on, towards the end of the film, another visibly tearful Muholi says, after screening photographs from their 2004 Aftermath exhibition are shown, which feature lesbians who have been raped and beaten, that they no longer wish to photograph the violence, or the aftermath of violence, and only wish to photograph "love". Muholi switches to their mother tongue and says: "I am hurting inside". With those two scenes from Difficult Love, it seems apparent to me that Muholi is experiencing secondary trauma. Secondary witnessing and secondary trauma was conceptualised by Marianne Hirsch (2003:9), whereby her "performative memory work" and her concept of "postmemory" emerged from an attempt to describe the

relationship of children of survivors of cultural or collective trauma to the experiences of their parents, experiences they 'remember' only as the narratives and images with which they grew up, but they are so powerful, so monumental, as to constitute memories in their own right.

Initially, her term "postmemory", coined in 1997, was an attempt to understand and account for a "familial inheritance" of memories for secondgeneration Holocaust survivors. Since then, Hirsch as well as other authors, such as James E Young (2018), Joshua Hirsch (2004), and Shoshana Felman (2001), has taken the term and 'broadened its application to a more general, cultural inheritance that can transcend ethnic or national boundaries' (cited in Hirsch 2003:9-10; cf. 2012). Postmemory is therefore "defined through an identification with the victim or witness of trauma, modulated by an unbridgeable distance that separates" the two. Postmemory is thus

retrospective witnessing by adoption - it is a question of adopting the traumatic experiences - and thus also the memories - of others as experiences one might oneself have had.

(Hirsch 2003:10, my emphasis) 
Hirsch privileges photographs as the affective prop or artefact by which traumatic memory is transmitted. It is a vicarious witnessing of 'seeing through another's eyes, of remembering through another's memories' (Hirsch 2003:10) that is so apparent in understanding Muholi's film and photographic works. Muholi's photographs provoke a vicarious and postmemorial witnessing of loss, a secondary trauma. Andreas Huyssen (1995:15) argues that these cultural artefacts or memory works open up an interpretive space around the artefact. No matter how "mediated and contaminated in the eye of the beholder", such artefacts have 'a surplus of meaning that exceeds set ideological boundaries, opening spaces for reflection and counterhegemonic memory' (Huyssen 1995:15): Muholi's works are considered to be "counter-hegemonic memory" not only with regard to history or politics but also, and most importantly, with regard to heteronormativity and Black lesbianism and trans.

One of the main reasons for Hirsch to coin the term "postmemory" had to do directly with representation of the unrepresentable. The purists or conservatives argue that only those who have experienced a trauma or atrocity first-hand, either as witness or as victim, are allowed to represent it. Of course, the problem with that is that most individuals who have been traumatised are not artists or writers or film makers. How then does one account for those artists who are able to convey such trauma with authenticity and integrity?

Postmemory is a powerful and very particular form of memory precisely because its connection to its object or source is mediated not through recollection but through imagination...

(Hirsch 1997)

Through "postmemory", a theory through which Hirsch argues that an individual can represent the horrors of war, genocide, and rape through identification, empathy, and imagination. In Muholi's art, there is all three.

Joshua Hirsch (2004) also views film as "vicarious trauma"; he adds to the trauma discourse by suggesting that after watching visual representations or visual recordings of trauma, the viewer often displays similar symptoms of trauma through the vicarious reliving of the traumatic experience. Even worse, those who encounter or watch many instances of such vicarious trauma themselves face the possibility of experiencing post-traumatic stress. E Anne Kaplan (2013:54) supports Hirsch's argument that individuals are vicariously traumatised: by that they mean that individuals suffer effects similar to trauma by watching the trauma of others. Traumatic memory, in its belatedness, involves a type of forgetting: victim-collectives or nations may also "forget" through a process of traumatic amnesia. Meanwhile, the discourse of those who do remember is often stifled or silenced: giving rise to conspiracy of silence. This includes viewing national traumas, such as the genocide in Rwanda represented in the films Hotel Rwanda and 
Shooting Dogs; or the ethnic cleansing of the Bosnian War, depicted in the film Savior and In the Land of Blood and Honey. It has taken almost 20 years before films about these national traumas were made. The same goes for the Holocaust and the Vietnam War. This is the significance of Difficult Love: it challenges the conspiracy of silence and documents the narratives of traumatised Black lesbians.

Muholi's photographs as well as this film reinforce Cathy Caruth's assertion in her book Unclaimed Experience that 'history [is] the history of trauma' (1996:10). As W G Sebald writes in his book Austerlitz (2001:16), 'the marks of pain ... trace countless fine lines through history', this refers not only to apartheid but to the history of atrocities perpetuated against lesbians - their history or histories. Cathy Caruth, one of the leading scholars in trauma studies, emphasises (1996:8):

the way in which one's own trauma is tied up with the trauma of another, the way in which trauma may lead, therefore, to the encounter with another, through the very possibility and surprise of listening to another's wound.

Muholi's film and works are a confrontation with South Africa's modern political democratic history as trauma, to challenge and to affect change; as well as to extinguish the phantoms that haunt contemporary post-apartheid society: they attempt to right the wrongs of apartheid - through bringing the community to galleries exhibiting their work and installations, through teaching those who are disenfranchised both visual literacy and photography. This film unveils actual horror and focuses on the displaced lives that gesture towards this horror.

W G Sebald, who grew up in Germany during the Second World War, also wrote that 'certain painters and philosophers who seek to penetrate the darkness which surrounds us, purely by means of looking and thinking' (2001:3-4): this too is an accurate definition of Muholi's works and film. She uses the film to point out the "darkness" of poverty, misogyny, grievous bodily harm, corrective rape, and exclusion in existence in South Africa.

Muholi's photographs, and most especially this film, seem predicated on Caruth's insight that the language of trauma and its repetition of suffering require a special mode of reading and listening a shared intimacy. This encounter with another's wound or traumata allows for the acknowledgement of another's wound. This witnessing of another's wound reflects history, both personal and collective: apartheid as well as rape and violence. Caruth's conception of trauma: 'that the most direct seeing of a violent event may occur as an absolute inability to know it' (1996:92), but a mediated viewing, such as through Muholi's works, ensures an ability to know and recognise it. That is the role of post-memorial trauma art, and the role of Muholi's works.

Jill Bennett in her book Empathic Vision: Affect, Trauma and Contemporary Art, published in 2005, argues that art has "unique capacities" to 
trigger an empathic response (cf. Luckhurst 2003, 2008) from the viewer that should not be an end in itself, but rather should lead to critical thought. This affective power of art is most especially found in the case where art draws from trauma, which as Caruth (1996) and Hirsch (2004) have argued, is traditionally defined as both beyond language and representation. Bennett argues that the visual arts are generative rather than simply representational. This too encapsulates Muholi's oeuvre: their works are not simply representational, but they are affective, and they offer a socio-economic and political critique as well as a sexual critique. Following on from secondary trauma is that of memorialisation.

\section{Memorialisation}

Muholi's works are a form of memorialisation. Memory and trauma studies have addressed how forms of memorialisation might transmit a cultural memory of trauma to those who did not witness the event first-hand. In the past century or so, activities of collective remembrance, or memorialisation, have proliferated. It takes several different forms from museums, memorials, art works, literature, street theatre, and ceremonies. It is a social act and an 'embodiment of the cultural act of memory and remembering' (Mhando \& Tomaselli 2009:34). Memorialisation can be understood as the practice whereby individuals, communities, and societies interact at sites of symbolically represented memory, deriving from and impressing on an item or act 'about specific times, places, persons and events laden with affective meaning' (Mhando and Tomaselli 2009:34). Memorialisation is viewed as a "search for meaning" through performance or enactment; memorials are "sites of memory" which encapsulate themes of catharsis, absence, loss, and remembering. Pierre Nora, a French social historian, claims that "lieux de mémoire" or "sites of memory" are monuments, museums, festivals, and even archives that document history (1989). He claims that these historical artefacts are essential to remembering histories that have been abandoned.

A "site of memory" or "lieux de mémoire" as defined and conceptualised by Pierre Nora (1989) can be seen as 'an active practice of remembering which takes an inquiring attitude toward the past and the activity of its (re) construction through memory ... undercutting assumptions about the transparency or the authenticity of what is remembered' (1989) and 'such sites of memory are always dynamic' (Mhondo \& Tomaselli 2009:35). Difficult Love reactivates memory as a way of negotiating the present, to generate a historical consciousness, where the evidence of recording testimony is not necessarily to preserve history for posterity but to 'tell their stories to the public, to be listened to, and to be acknowledged' (Mhondo \& Tomaselli 2009:35). Not only is Difficult Love a "site of memory" or an artefact of memory, wherein individuals recount not only their traumatic experiences, but $\mathrm{Mu}$ holi's exhibitions, where Muholi takes in groups of community youths from their community to view their works; these too are "sites of memory": the 
gallery becomes a structure of memorialisation wherein their works engage both the individual and the community separately and mutually in a process of conversation and discourse. Their film and photographic works are significant in that they raise political, social and historical consciousness.

As James E Young (2018) puts it, cultural artefacts articulate a loss, they articulate a void, and they present an absence. For Young, we can never really understand the unrepresentable; however, the best way to engage with such a dilemma is to look at their representations. For Muholi, this is especially true: in a brief column that they wrote about Faces and Phases exhibition, some of these photographs appear in this film, they stated that many of their models have died since they took their photographs. It is this sense of overwhelming loss that is provoked in those who view these cultural artefacts or memorials, or "memory works", such as art, architecture, films, and photographs; it is a sense of shock, something akin to trauma. As Young argues, it is a sense of shock that provokes remembrance of things not witnessed: a vicarious or secondary witnessing. And once again we are back to trauma and memory studies. These photographs are used as conduits of trauma to transmit traumatic memories. The more recent theoretical work of trauma and memory is underpinned by a concern that traumata must be shared. In Difficult Love we have both: Muholi's secondary witnessing, their photographs from their Aftemath series; as well as the first-hand testimony of Millicent Gaiku. Through this film all of these traumata become shared trauma.

\section{Conclusion}

In concluding, I quote Fariba Derakshani (Humbane 2014) in her keynote address at the opening of Muholi's exhibition Love and Loss, in February of 2014, held at the WITS Arts Museum in conjunction with the Stevenson Gallery, where they stated that Muholi was

a revolutionary who has had great impact in advocating and empowering black LBGTI communities of South Africa. Through her [sic] lenses, she $[s i c]$ has shot and offered a voice for black LGBTI stories which will live ahead of time in history.

This again is evidence that their work will not only be archival in nature, but a form of memory work, of memorialisation. Muholi has used their art as a lens to examine political and historical issues of experience, trauma, memory, the body, sexualit(ies), identity, and representation. Their film and photographs are a unique "politics of perception" (Wallis \& Duggan 2011:2), and they help render accessible the shattered experiences of politics, postmemory, trauma, lesbianism, apartheid, colonialism, and history. In concluding, this film and Muholi's photographs, in different but similar ways, incorporate themes of politics, colonialism, imperialism, reconstruction 
and reclamation of identity, subjectivity and lived realities (context(s) and multiverses); and most importantly it offers testimony. Not only Muholi's own personal stories but also those of the lesbian communities: the film and photographs become the "story-tellers"; they bear witness to political injustices, physical and psychological traumatas; and, as such, they argue for change, transformation, social justice, and reflection. Muholi is involved in participatory politics; she communicates about politics through her anticolonial lens and her community engagement projects. As Muholi (cited in Abel-Hirsch 2020) astutely states: 'My images are portraits, so if my work is being exhibited, someone else's existence is also being affirmed. What matters is having a dialogue - with people, with institutions and with history. It's a collective project of reclaiming space' and history. Thus, Muholi calls for the decolonisation of the mind and imagination, the raising of consciousness (of trauma), as well as the decolonisation of the politics of gender, colonialism, apartheid, and heteropatriarchy.

\section{Notes}

1 Muholi identifies as non-binary and therefore uses the pronoun they/them, as they have often stated, they identify as a human being.

2 The South African public broadcaster.

3 For example, the Lesbianism and Genre Award granted by the Equality, Cooperation and Citizenship Area of the Council of Bilbao in Spain.

4 Muholi has a similar project now, Women's Mobile Museum, 2018, with Lindeka Qampi: they create and mentor women in Philadelphia, using digital camera work; Photoshop; and even teaches them how to set up photography exhibitions and installations.

5 In 1996 South Africa became the first constitution in the world to outlaw discrimination based on sexual discrimination, and in 2006, it legalised same-sex marriage (Abel Hirsch 2020).

\section{References}

Abel-Hirsch, H. 2020. Zanele Muholi: Art and activism. British Journal of Photography. https://www.1854.photography/2020/07/zanele-muholi-art-and-activism/ http://archive.stevenson.info/exhibitionsbs/muholi/index.htm

Bennett, J. 2005. Empathic vision: Affect, trauma, and contemporary art. Palo Alto, CA: Stanford University Press.

Brodie/Stevenson Gallery. 2009. Zanele Muholi: Curatorial notes.

Caruth, C. ed. 1995. Trauma: Explorations in memory. Baltimore, MD: Johns Hopkins University Press.

Caruth, C. ed. 1996. Unclaimed experience: Trauma, narrative, and history. Baltimore, MD: Johns Hopkins University Press.

Dussel, E. 1977. Philosophy of liberation. Translated by A Martínez and C Morkovsky. New York: Orbis Books.

Goldsmid, P. \& Muholi, Z. (dir). 2010. Difficult love. [Film]. Johannesburg: South African Broadcasting Corporation. The entire film can be viewed for free at: https://www.imdb.com/video/vi3128728089 
Grosfoguel, R. 2011. Decolonizing post-colonial studies and paradigms of politicaleconomy: Transmodernity, decolonial thinking and global coloniality. Transmodernity: Journal of Peripheral Cultural Production of the Luso-Hispanic World 1(1): $1-38$.

Hirsch, J. 2004. After image, trauma and the Holocaust. Philadelphia: Temple University Press.

Hirsch, M. 2003. Mourning and postmemory. In The Holocaust. Theoretical readings, edited by N. Levi and M. Rothberg. Edinburgh: Edinburgh University Press Ltd., 416-422.

Hirsch, M. 2012. The generation of postmemory: Writing and visual culture after the Holocaust. Columbia: Columbia University Press.

hooks, b. 1995. Art on my mind. Visual politics. New York: The New press.

Humbane, A. 2014. "Black South African visual artist lesbian, Zanele Muholi, in a transparent coffin of love and loss". https://inkanyiso.org/2014/02/24/2014-feb14-black-south-african-visual-activist-lesbian-zanele-muholi-in-a-transparentcoffin-of-love-and-loss/

Huyssen, A. 1995. Twilight memories: Marking time in a culture of amnesia. London: Routledge.

Kaplan, E.A. 2005. Trauma culture: The politics of terror and loss in media and literature. New Brunswick, NJ and London: Rutgers University Press.

Kristeva, J. 2002. Intimate revolt: The future of the culture of revolt, the life of the mind and the species. In The portable Kristeva, edited by K Oliver. New York: Columbia University Press, 435-447.

Luckhurst, R. 2003. Traumaculture. New Formations 50(1): 28-47.

Luckhurst, R. 2008. The trauma question. London and New York: Routledge.

Nora, P. 1989. Between memory and history: "Les lieux de mémoire". Special Issue: memory and counter-memory. Representations 26(Spring): 7-25. https://doi. org/10.2307/2928520

Mhando, M. \& Tomaselli, K.G. 2009. Film and Trauma: Africa speaks to itself through Truth and Reconciliation films. Black Camera 1(1): 30-50.

Mignolo, W. 1995. The darker side of the renaissance: Literacy, territoriality and colonization. Ann Arbor: Michigan University Press.

Mignolo, W. 2000. Local histories/global designs: Coloniality, subaltern knowledges, and border thinking. Princeton University Press.

Mignolo, W. 2011. The Darker side of the Renaissance: Literacy, territoriality and colonization. Ann Arbor: Michigan University Press.

Ndlovu-Gatsheni, S. 2013. Coloniality of Power in Postcolonial Africa: Myths of Decolonzation. Dakar; Council for the Development of Social Science Research in Africa. https://codesria.org/IMG/pdf/0-Coloniality_of_Power_Ndlovu_Prelim. pdf?3311/c4053b4df101ba6371f78777ee747f6e74e26679.

Quijano, A. 1991. Coloniality and modernity / rationality. Indigenous Peru 13(29): 1120.

Quijano, A. 2000. Coloniality of power and social classification. Journal of World Systems Research VI(2): 342-386.

Sebald, W.G. 2001. Austerlitz. Translated by A Bell. Oxford: Random House.

Van der Schyff, M. 2015. A content analysis into the framing and representation of 'corrective rape' in three South African newspapers. https://ukzn-dspace.ukzn. ac.za/handle/10413/13179 
Van der Schyff, M. 2018. An issue of social and political salience: a content analysis of how South African newspapers report on 'corrective rape'. Global Media Journal 11(1) https://globalmedia.journals.ac.za/pub/article/view/281

Wallis, M. \& Duggan, P. 2011. Editorial: On trauma. Performance Research: A Journal of the Performing Arts 16(1): 1-3.

Wood, J.T. 2013. Gendered lives: Communication, gender and culture. Australia: Wadsworth/Cengage Learning.

Young, J.E. 2018. The stages of memory: Reflections on memorial art, loss and the spaces between. Amherst: University of Massachusetts Press. 


\title{
5 Documentary film as political communication in post- apartheid South Africa
}

\author{
Miners Shot Down
}

Pier Paolo Frassinelli

\section{Introduction}

In this chapter, I discuss the role of documentary film as political communication in post-1994 South Africa. In particular, I want to look at how this genre has been used to reframe narratives of current political events and social issues. The internationally best-known example is Rehad Desai's Miners Shot Down (2014), which won several international and national awards - including the International Emmy Award (2015), the Festival panafricain du cinéma et de la télévision de Ouagadougou (FESPACO) (2015) and the South African Film and Television Award (2015) for best documentary film - and decisively contributed to change South African public discourse on the Marikana massacre, where 34 striking mineworkers were shot dead by police on 16 August 2012. Miners Shot Down has been described in the South African press as the 'film every South African should see, and never forget' (Thamm 2014). It became part of a forensic case that indicted 'the police, the government and the Lonmin mining company [the employer of the striking miners] for their respective roles in the most deadly display of violence witnessed in post-apartheid South Africa' (Thamm quoted in docimpactaward 2016, 12).

But there are other documentaries that have subverted dominant and state-sanctioned narratives of post-1994 events and realities. For some time, South Africa has had one of the highest numbers of community and other forms of protest of any nation (see, among others, Alexander 2010; Duncan 2016). Most of these protests have been waged by poor communities affected by the transition from apartheid to a version of neoliberalism only partially attenuated by state support for the poor in form of social grants, which has made South Africa one of the most unequal countries in the world. Documentary film has been one of the representational forms that have been used to speak to the contradictions and struggles engendered by this "elite transition" (Bond 2014).

Examples of documentary films where the filmmaker presents a conflict or dissonance between, on the one hand, official and mainstream discourses, and, on the other hand, voices, events and actions that challenge 
or subvert them include Dara Kell and Christopher Nizza's Dear Mandela (2012), on the struggles of shack dwellers in Durban; Rehad Desai's The Giant Is Falling (2016) and Everything Must Fall (2018), which together with Miners Shot Down constitute a trilogy that tackles enduring inequality in South Africa; Lebogang Rasethaba's The People Versus the Rainbow Nation (2016), which reframes post-apartheid South African history in the wake of the \#RhodesMustFall and \#FeesMustFall movements as the failure of the ideal of the rainbow nation; Aliki Saragas's Strike a Rock (2017), on the lives of the women and community of Marikana after the massacre; and Kurt Orderson's Not in My Neighbourhood (2018), where Cape Town is singled out, together with Sao Paulo and New York, as an example of a city where gentrification is producing new forms of spatial apartheid. Each of these documentaries provides an oppositional and alternative counter-framing of contemporary social and political realities, thereby producing a decolonial counterpoint to official discourse by exposing the pitfalls of post-1994 national consciousness. They are all significant examples of how documentary film can be used to destabilise and challenge the narratives that legitimise the power of postcolonial elites and their transnational economic and political networks. ${ }^{1}$ This use of documentary film thus challenges a narrowing of mediated political communication that often privileges the views of "political and social elites", while "the experiences and concerns of the majority of the country's citizens" are 'ignored, marginalised or used as a tool to score political points' (Wasserman 2015, 278).

Miners Shot Down responded to this narrow model political communication, which, as we will see, was reproduced in the mainstream media coverage of the Marikana massacre, through a counter-narrative that exposes the role of the state and capital in the massacre, and through its involvement in a campaign in support of the miners, their communities and their quest for justice and the truth. As I am going to discuss, Desai's film is not only a hard-hitting documentary. It has also been part of a collective effort involving the Marikana miners and their families and communities, as well as grassroots organisations and social justice activists to contest and replace the narrative of the massacre that was hastily cobbled together by the South African government and its political supporters and mainstreamed by South African media in the weeks immediately following the massacre to blame its victims on it.

\section{The Marikana massacre}

Miners Shot Down documents an event that represents a turning point in South African history. The name of the small town where the massacre of 34 striking miners by the South African police took place on 16 August 2012 has become a periodisation marker that places South Africa in what we may call the post-Marikana period, the aftermath of the lowest point in post-1994 history. 
On 10 August 2012, miners in the platinum industry downed tools to demand a living wage of 12,500 rands (about 800 euros/950 US dollars at the time) per month. The epicentre of the strike was the informal settlement of Wonderkop, near Marikana in the North West Province, where the miners congregated on a koppie (small hill). The massacre was the culmination of a concerted effort by the transnational mining corporation Lonmin and the South African government to break this "unprotected" strike - in that formal pre-strike procedures had not been implemented - during which the miners had taken on both their employer and the National Union of Mineworkers (NUM) (see Alexander et al. 2012).

Official discourse about the massacre was first shaped by government statements, which were initially aimed at erasing state culpability and presenting the massacre as an accident, or indeed as the result of the strikers' actions. Early comments and statements by state representatives often appealed to the notion of national unity, thereby implying that the events of the previous week had disrupted it and forced the hand of the police. In clips included near the beginning of Miners Shot Down, immediately after the first images that show the police using live ammunition to mow down the strikers, we see President Jacob Zuma stating in an address the day after the massacre, 'this is not a day to apportion blame. It is a day for us to mourn together as a nation. It is also a day to start rebuilding and healing'. This is followed by a cut to another speech by National Police Commissioner Riah Phiyega, who insists,

the SAPS [South African Police Service] did all in its power to avert a situation such as this ... and the police members had to employ force to protect themselves from the charging group. This is no time for blaming. This is no time for finger pointing. It is a time for us to mourn a sad and dark moment we experience as a country.

In the days and weeks after the massacre, the striking miners were presented 'as an unruly and dangerous mob who needed to be controlled and contained' (Sinwell, Lekgowa, Mmope and Xezwi 2012, 3). Their voices were silenced. As Jane Duncan shows in her study of the early press coverage of the massacre, out of 153 articles she examined:

only one miner was quoted on what actually happened during the massacre, and he said the police shot first. Most miners were interviewed in relation to the stories alleging that the miners had used muti [traditional African medicine] to defend themselves against the police's bullets, as well as the miners' working and living conditions. So in other words, of all 153 articles, only one showed any attempt by a journalist to obtain an account from a worker about his versions of events.

(Duncan 2015, 182) 
While acknowledging the excessive use of force by the police, and in particular the dangers with the use of live ammunition - which would have been exceedingly difficult to deny - the various versions of this narrative still managed to blame what NUM general secretary Frans Baleni described as the 'dark forces who can mislead our members, make them to believe that they've got extra power to make their life to be different overnight' (Baleni 2012 , n.p.). The striking miners were consistently portrayed as backward traditionalist men misled by opportunists and reactionary forces. South African Communist Party (SACP) General Secretary Blade Nzimande wrote that 'attempts by the opposition to liken police reaction in Marikana to that of the apartheid regime is outrageous [sic], no matter how unacceptable death is'. He condemned 'cheap politicking [...] in trying to lay the blame at the door of government and narrowly the police', and called for an investigation into the:

essentially backward beliefs and practices amongst sections of the working class. [...] Just how does a sangoma [traditional healer] is [sic] today still able to convince sections of the working class that bullets turn into water if you have used "intelezi" [traditional plant medicine], is something that we should no longer be talking about in a hush hush manner but should openly engage, albeit sensitively.

(Nzimande 2012, n.p.)

In the same vein, a police spokesperson claimed in an interview: "we were dealing with people who looked possessed, or believed the bullets would not work on them' (quoted in Duncan 2015, 191).

This discursive strategy rationalised the massacre by othering the miners and presenting them as naïve and credulous men who had been misled by "sangomas" and "turned into automatons by the muti, lulled by their own superstition into believing that they were invulnerable to police bullets' (ibid., 191). In addition, early reporting attributed the conflict to interunion rivalry between the NUM and the Association of Mineworkers and Construction Union (AMCU). In line with this interpretation, journalists 'seemed to assume that including union voices was sufficient to "cover" the workers' voices' (ibid., 187). Media reports covered workers' actions as if they could be explained by reference to the role played 'by a rogue union, or by agitators, or by political troublemakers' (Brown 2015, 12).

This same erasure is replicated in the report on the massacre compiled by the Marikana Commission of Inquiry presided by Judge I. G. Farlam (Farlam Report), which was released to the President of South Africa on 31 March 2015 and to the public on 25 June 2015. The report's findings are based on the notion of "common intent", whereby the miners are construed as a homogeneous, monolithic entity. As Socio-Economic Rights Institute of South Africa (SERI) Director Stuart Wilson underscored immediately 
after the release of the report, nobody is held responsible for ordering the massacre: 'After 300 days of hearings (page 16) the Commission merely recommends "further investigations" (pages 545 and 546)'. Wilson notes:

the report tends to treat both the living and the dead - especially the miners - in a highly generalised way. Intentions and motives are assigned to groups of people, not individuals. [...] What Judge Farlam offers is an unsatisfactory narrative of faceless crowds and poorly-judged decisions, where responsibility, if it is apportioned at all, is doled out in the abstract.

(Wilson 2015, n.p.)

The usefulness of the report in explaining what happened in Marikana is, by its own admission, limited. Its findings and the evidence on which it is based were circumscribed by the Commission's terms of reference, which precluded it from addressing matters such as the migrant labour system, the labour relations system on the mines, and the role and performance of the Department of Mineral Resources. Also excluded from the scope of the investigation was the role of 'other departments or agencies pertaining to the tragic incidents' (Marikana Commission of Inquiry 2015, 14). In other words, the Marikana Commission of Inquiry was prevented from investigating the political responsibility for the massacre. What we have as a result 'can't be anything approaching the whole story' (Wilson 2015, n.p.).

But what is "the whole story" of the Marikana massacre? Miners Shot Down attempts to answer this question by framing the narrative within two temporal axes that respectively zoom in on the immediate events that led to the massacre and take a longer view of the historical sequence that frames it in the South African transition to democracy.

\section{Miners Shot Down}

Set in the cold, arid winter of the koppies of Marikana, in the platinum belt situated a couple of hours drive from Johannesburg, the film juxtaposes the director's footage and interviews with workers, their legal representatives and politicians with media coverage and police and security videos. It also includes plenty of aerial shots that 'contrast the massive scale of the mine with the small town where the workers live adjoining it and the barrenness of the terrain beyond it' (Moyer-Duncan 2019, 60). Desai's documentary shows us a group of workers who break with the union bureaucracy to try to directly address the company they work for, Lonmin, and demand better wages for their labour. Led by rock drill operators, the workers go on strike and assemble by the mountain near the informal settlement where many of them live, determined to hold fast to the demand for 12,500 rands per month and force the employer to negotiate with them. 
But the story told in Miners Shot Down goes beyond the events narrated in the film to speak to overlapping temporalities and geographies:

beside being a precious record of history in the making, the film is an unique exploration of the tension governing South Africa in the current phase, and a complex interweaving of local and global interests that bear on the country's contemporary politics.

(Oboe 2014, 4-5)

As said, Miners Shot Down is chronologically framed by two narratives. The first is that of the six days before the massacre of the striking workers which saw the death of at least four miners, two police officers, and two security guards - underscored by the sequence of titles that bring us closer and closer to the event and slice the film, which opens with white characters on a black screen: "Wednesday 10 August 2012 - 6 days before the massacre". This is the narrative that "provides forensic proof that the police attack was planned, that the mineworkers were on their way home when attacked and that 17 mineworkers were executed at short range' (Thamm quoted in docimpactaward 2016, n.p.).

Interspersed with this exposé of state, police and Lonmin's culpability for the Marikana massacre, we have flashbacks that insert it into the unfolding history of South Africa's long transition to a democratic dispensation that, to fulfil its mandate, should rid itself of the legacy of colonialism and apartheid. Miners Shot Down thus points to two distinct but interconnected historical contexts. One is the growing securitisation and militarisation of the police force and more generally the state (Duncan 2015), which is today both a South African story and a global story (Giroux 2015). Related to this, there is the centrality of the extractive industry and the mining sector in the South African and continental economy, whose role in the neoliberal world order remains that of a supplier of raw materials, especially minerals and oil (Ferguson 2006: 194-210). Juxtaposed to this frame, there is a more extended national narrative which, as the voiceover in the opening scene tells us, takes us back to the history of apartheid and the liberation struggle, whose high points were punctuated by the mass killings in Sharpeville (1960) and Soweto (1976), as well as by the popular rebellion that led to the demise of white minority rule.

These are the two convergent temporal frames that in Miners Shot Down construct the Marikana event as a story of betrayal of the "people" by the liberation struggle's political elite, who had seized power in the people's name and is now colluding with international capital to undermine its historical mission. The documentary makes abundant use of voiceover in the first person singular, which occasionally becomes a plural we, by Rehad Desai, who bears witness to this betrayal together with "fellow South Africans". This historical frame is introduced right at the beginning of the film, in the title sequence, where the footage of police firing at the miners is 
followed by the filmmaker's account, which brings us back to the brutalities of the apartheid regime, the liberation struggle and the transition to democracy (for a discussion of the title sequence, see Strauss 2016, 64-68):

It's the 16th of August, 2012. Outside the Lonmin Platinum mine Marikana, South Africa, a hundred and twelve striking miners are shot down by police. Thirty-four die. Like many South Africans, the shooting shook me to the core. Events like these took me back to the massacres of apartheid: Sharpeville, 1960; Soweto, 1976. Killings like these led South Africans to support Nelson Mandela and his struggle for freedom. But today, these miners are being shot at by our new government to ensure that it's business as usual. We could see that lives were now being sacrificed for money, and that the young democracy we had so much hope for was under threat.

Key among the references to the betrayal of the liberation struggle in Miners Shot Down are the images of South African president Cyril Ramaphosa, the former president of the NUM and a prominent figure in the liberation struggle turned hugely wealthy politician and businessman, who at the time of the massacre was the executive chairman of Shanduka Group, "the majority shareholder of the Lonmin black empowerment subsidiary, which gave him 9 per cent ownership in Lonmin and a seat on the board' (Saul and Bond 2014, 228).

The voiceover tells the viewer that "The story of the Marikana massacre would be incomplete without a close look at the involvement of Cyril Ramaphosa", who is first seen through the footage of an earlier version of himself as the leader of the NUM interspersed with images of rallies and marches. The voiceover continues,

I had watched him with admiration as he built the largest trade union the country had ever seen: the National Union of Mineworkers. Under Cyril's leadership, NUM saw the miners join the fight against apartheid. And I took my place marching side by side behind their banner.

From there, the film cuts to a press conference where we hear a young and radical Ramaphosa declaring, 'It must be remembered that it was the mining industry, and specifically the Chambers of Mines, which pioneered the most oppressive features of apartheid South Africa'. Then, after another clip of militant miners' struggles during which the voiceover underscores how his leadership of the NUM made him a key figure in the birth of the new South Africa, we have Ramaphosa stating, 'There is no such thing as a liberal bourgeois. They are all the same. They use fascist methods to destroy workers' lives'. At all the screenings that I have attended, this statement unfailing prompted laughter from the audience, which clearly thought of Ramaphosa's present position as a prominent member of the very same class 
he associates with fascism. The statement is followed by footage of Ramaphosa first introducing Nelson Rolihlahla Mandela during a rally and then cutting a MacDonald's cake - in 2011, Ramaphosa acquired the ownership of all McDonald's assets in South Africa, including property (Peyper 2016). The voiceover goes on:

He soon became a leading member of the African National Congress, and from this position joined the black economic elite. Ramaphosa, who once saw South Africa's working class as a force to bring about change, now found himself on the other side of the table. At the time of the massacre, he was a board member of Lonmin.

Ramaphosa continues to provide a counterpoint to the narrative throughout the documentary. As the day of the massacre approaches, the story is interjected with more clips of the current president of the Republic of South Africa first as a union leader, then next to Nelson Mandela in 1990, as a businessman and ANC leader, and in a reticent interview with the director.

This narrative counterpoint culminates with the exposure of Ramaphosa's involvement in the massacre. The film shows transcripts of emails he sent to lobby government ministers to increase police presence and press for action to be taken against the miners. The most disturbing message was sent the day before the massacre. It states that the actions of the miners 'are plainly dastardly criminal and must be characterised as such. In line with this characterization there needs to be concomitant action to address the situation'.

Early in the film, the voiceover had asked: "who sanctioned the order to use live ammunition against the strikers?" Ramaphosa's involvement and the suggestion that orders came or had at least been sanctioned right from the top of the South African state are the documentary's answer to this question.

In this narrative, the Marikana massacre comes straight out of pages on "the pitfalls of national consciousness" in Frantz Fanon's The Wretched of the Earth (1961), where the postcolonial elite, acting as intermediary for transnational capital and unable to "rationalize popular action", brings about such a high level of "exploitation and such contempt for the state" that it 'inevitably gives rise to discontent among the mass of the people. It is in these conditions that the regime becomes harsher' (Fanon 1961 [1965], 149 and 174). This historical narrative is framed by the threat that the collusion between the post-apartheid government and capital represents for "the young democracy we had so much hoped for". The African National Congress's 1994 "Reconstruction and Development Programme" described this political dispensation as capable of combining elements of "representative, participatory and direct democracy" (RDP 1994, 119). The strike, during which the miners had taken on both their employer and their union, went against the institutionalised model of participation defined by 
the corporatist system regulating labour relations that has at its centre union representation, recognition agreements and the collective bargaining system that are supposed to ensure workers' participation in matters concerning salaries and working conditions. The Farlam report underscores that Lonmin refused to talk to the strikers outside organised bargaining structures. It is against this institutionalised system and organised structures that had failed them for so long that Lonmin miners went on strike. As Stuart Wilson argues:

To the striking miners of Marikana, to participate in the existing structures of collective bargaining and labour dispute resolution was to acquiesce in a system in which they had lost faith. The rejection of "participation" took them beyond the mechanisms through which their political agency could be assimilated and dispersed, which is why Lonmin and the state were so threatened by it.

(Wilson 2014, n.p.)

Miners Shot Down is an indictment of South African democracy, underscored by footage of leading state figures Cyril Ramaphosa, Jacob Zuma and Riah Phyiega, none of whom is prepared to take responsibility or apologise for what happened in Marikana on 16 August 2012. In the words of former Minister of Intelligence Ronnie Kastrils, who is no longer a member of the ANC:

It is the time to point finger. In the first place, to point finger at those whose fingers pulled the trigger. But foot soldiers... what about those who pulled the strings, who gave the orders. And who are they? Tell me. Who are they? Minister of police? President? He's got to answer.

In trying to answer some of these questions, Miners Shot Down directly challenged the narrative provided by South African media immediately after the event. This narrative was shaped by government's spin, which came in different shades and tones, some more cynical and brazen than others, but with a refrain: the silencing of the dead. The film mounted this challenge not only through its retelling of the story of the event but also by participating in a campaign involving the miners and their families, as well as grassroots organisations and social justice, independent media and other activists to contest the dominant narrative of the Marikana massacre - which has come to be known by this name largely because of this campaign - and seek justice for its victims.

\section{The social and political life of Miners Shot Down}

Among the film's achievements, there is the 2016 Doc Impact Award, which celebrates 'the documentary films that have made the greatest impact on 
society' (docimpactaward 2016, 5-6). This award was a recognition for the role of the documentary in revealing the truth about the Marikana massacre and in the Marikana Support Campaign. An analysis of this film - of the way it frames and narrates the history of the Marikana massacre - would therefore be incomplete without a discussion of its social and political life.

The filming of the documentary started simultaneously with the multimedia campaign that accompanied and followed its production and release. As Desai recalls, in 2012 he was working on a film project in an area near Marikana when he started filming the miners' strike. Then the massacre happened: 'I was very angered and moved to do something, so we started filming immediately and set up a Facebook group on the same night. It was called "Justice Now for the Marikana Strikers" (Frassinelli 2016, 423). The documentary was completed and first screened at the beginning of 2014. Even before it officially opened in South African cinemas, it was shown up and down the country in auditoriums, universities, township halls, clubs and homes. People were encouraged to get a copy, organise a screening and invite their friends and neighbours.

Before the film was released, the multimedia campaign was in full swing. The producer, Anita Khanna, recalls:

we continuously made small clips. We put them out on the Internet and they went viral [...] we were constantly being like some sort of conduit channelling all this information through different vehicles and platforms to put it out to different groups of people.

(Quoted in Frassinelli 2016, 24)

This campaign involved multiple levels, both online and offline, and one of its highlights was the screening of a rough cut of the film, in December 2013, a few months before the official release, for 1,200 members of the National Union of Metalworkers (NUMSA) at the Special National Congress that would lead with its break with the Confederation of South African Trade Unions (COSATU) and the ANC (docuimpact 2017, 34). Other events included a tour of South Africa that began in April 2014:

Using a mobile cinema kit, the campaign brought the film to schools, universities, churches, independent movie clubs, and people's living rooms - and when possible, included a lawyer from the Commission and/or a mineworker from the film. Screenings were also held outside platinum mines using large exterior spaces. In one screening alone, 4,000 miners stood in silence watching the film. The filmmakers re-versioned the film into local languages to increase accessibility on the tour.

(Ibid., 19)

The campaign coincided with the more traditional routes of film distribution, including sales, and theatrical and festival release. Miners Shot Down 
was released in South African cinemas in May 2014 at the high-end art cinema Cinema Nouveau, which is part of the Ster Kinekor chain, where, thanks to good audience turnout, it 'ran for three weeks, two weeks longer than the initial week committed to' (ibid., 28).

In addition, DVDs were produced and sold by community members of the campaign for a small profit, with over 7,000 DVDs sold in South Africa in the first 18 months (ibid., 28), including '1,400 directly to mineworkers at the Marikana Commemoration in 2014' (ibid., 20). Still in August 2014, there were 11,000 views on YouTube over the course of three days (ibid., 35). On the occasion of the same commemoration, the campaign enlisted the support of the widows of the miners to present a memorandum to the two South African free-to-air broadcasters, eTV and the SABC, demanding that the film be shown to the South African public - it would only be broadcast, as a result of a prolonged campaign and of the film's national and international acclaim, on eTV on 13 and 20 January 2016 and on SABC on 9 August 2019. The two broadcasts on eTV trended on Twitter, with more than 25,000 tweets after the first broadcast, as people took to social media to say 'that they hadn't known what had happened at Marikana until seeing the film' (ibid., 42).

The film's budget was 551,475 US dollars and that of its impact campaign 244,701 US dollars (ibid., 53). Up to 2016, it had 133 official international screenings in 23 countries, and 289 cinema and festival screenings and 150 community screenings in South Africa. It scooped a total of 15 awards at various national and international film festivals (ibid., 27-28). The Marikana miners and their communities participated in many of the community screenings. Anita Khanna recalls:

In the process of doing all these things we all changed as people, our roles changed. You get things like the mineworker not just being there to speak but also dealing with the equipment. You get the person dealing with the equipment getting out and speaking and translating. You get Rehad putting out the chairs. It became a very democratic, collective type of approach to the way we were doing things.

(Quoted in Frassinelli 2016, 432)

So, what does all of this tell us about Miners Shot Down and documentary film as political communication?

\section{Conclusion}

Miners Shot Down and the multimedia Marikana Support Campaign point to the possibilities for mobilising film, media and cultural resources in struggles for social justice, which in this instance were premised on revealing the truth about what Advocate Dali Mpofu, who represented arrested and injured miners, described at one of the hearings of the Marikana Commission of Inquiry as "a collusion between the state and capital". The question to 
which we must return then is, what is the "truth" about Marikana? How can a documentary film tell the "whole story" of the massacre?

Certainly, the story told by Miners Show Down is a partial one. It focuses on the miners and their struggle for a fairer wage. But it has little to say about the role in this struggle of their communities and especially of women, who are the backbone of these communities but whose voices are absent in the film. It has also been criticised by filmmaker, activist and author Gillian Schutte for choosing to focus on the role of Cyril Ramaphosa and of Lonmin black spokesperson, Barnard Mokwena, while ignoring Lonmin white chief executive, Ian Farmer, and opting instead for "Casual references to the "capitalists", "the Lonmin mine owners", "the management", thereby letting white business and transnational capital off the hook (Schutte 2014).

Indeed, the Marikana massacre is not just a South African story. Lonmin plc, the mining company that employed the workers killed by South African police, is a multinational corporation headquartered in London and listed on the London stock exchange whose presence in southern Africa goes back to when it was incorporated in the United Kingdom on 13 May 1909 as the London and Rhodesian Mining and Land Company Limited. Its involvement in the massacre is outlined in the documentary by Marikana families' lawyer James Nichol, who notes:

we now know that this was a joint operation between Lonmin and the police: that Lonmin was completely integrated into the police strategy and assisted the police strategy. It provided a senior executive to be part of the police team; they briefed the police offices and senior generals at least once every day; they provided helicopters and went out on surveillance expeditions with the police; they provided detention facilities; and at the very end of the day, after all the killings were done, they provided the Lonmin game farm for the debriefing.

South Africa is home to $80 \%$ of the world's known platinum reserves. The small town of Marikana is part of its platinum belt, which stretches from the North West, Gauteng and Mpumalanga provinces all the way up to Limpopo (Saul and Bond 2014, 215). This geographical location is thus both "local" and "global": it is inserted in the transnational circuits of capital that delineate the global geopolitical economy of mineral-resource extraction and continue to bring western-based and, increasingly, eastern-based multinationals to the rich mineral enclaves and natural resources of sub-Saharan Africa.

Schutte's critique points to real issues with the film. All representations are partial. They are a specific take on reality. As Stuart Hall reminds us, 'Meaning "floats". It cannot be finally fixed. However attempting to fix it is the work of representational practice' (Hall 2013, 228). One is also reminded of what African American novelist Toni Morrison calls the "distinction between facts and truth", whereby 'facts can exist without human intelligence, but truth cannot' (Morrison 1995, 93). Morrison refers to the embodied, lived 
truth of historical events and their affective, as well as historical and political dimensions. This is, for instance, the truth of the widows of the slain Marikana miners who had to fight to tell their version of the story to a disinterested Commission of Inquiry. This is truth of Betty Gadlela, one of the widows interviewed in another documentary produced by SERI and directed by Dara Kell, who says, 'Nobody knows the dreams our families had' (2016).

It is also the truth, repeated by many, including Rehad Desai in the voiceover right at the beginning of Miners Shot Down, of how what happened in Marikana painfully revived images of apartheid era state massacres. In the words of South African poet and sculptor Pitika Ntuli, whose art installation 'From Marikana Hill to Constitution Hill' (2013-2015) brought the Marikana massacre to the site that perhaps more than any other represents the aspirations that accompanied the transition from apartheid to democracy: 'I think that what hit us most as a society is that we thought the era of mass killings was over with apartheid. To have our democratic government allowing this to happen is shocking' (quoted in Frassinelli 2019, 126). As theologian Tinyiko Sam Maluleke added at the launch of the installation, 'If the democratic dispensation has not cured us from our rites of blood, what will?' (quoted in ibid.).

Moving from facts to truth is not just a matter of digging up evidence and providing a detailed forensic account of the events that took place much as this was needed. Facts do not speak for themselves: they need interpretation - encoding and decoding - to be narratable and representable and make sense to an audience. Still today, the question we are still trying to answer is not just what happened in Marikana on 16 August 2012, but how could it happen.

In an interview I conducted with the film's director and producer, when I asked why Miners Shot Down has had such a powerful impact on audiences worldwide, Khanna replied:

The short answer is that they were massacred, that's why. Because of state violence, because it was shocking, and because it's a democracy. Because it was the ANC, the party that all over the world people have been looking up to; the party about which they were saying, "Wow, what an amazing achievement, they fought apartheid and the country didn't break down afterwards, they still have a democratic state, social democracy".

(Frassinelli 2016, 429)

In other words, a big chunk of "truth" about this event is the historical significance of the time and place where it happened: a nation-state still seen by many as a model postcolonial dispensation and a successful multiracial democracy built on the ruins of the apartheid system.

Its shortcomings and omissions notwithstanding, Miners Shot Down remains a fundamental documentary because of how it makes us reassess a recent historical event by shedding light on the culpability and responsibilities of the South African state and its repressive apparatus. Its disclosure of how 
Black African workers were massacred by the post-apartheid state forces us to reassess the legacy of the apartheid system in post-1994 South Africa. Lastly, this is an important documentary because it shows how documentary film can become an agent of change and mobilising tool in struggles for social justice.

\section{Note}

1 Cara Moyer-Duncan uses the definitions "new resistance films" and "resistance documentaries" to describe some of these works and compare them to antiapartheid resistance films and documentaries (Moyer-Duncan 2019).

\section{References}

Alexander, P. 2010. "Rebellion of the Poor: South Africa's Service Delivery Protests A Preliminary Analysis". Review of African Political Economy 37 (123): 25-40.

Alexander, P., B. Mmope, T. Lekgowa, L. Sinwell, and B. Xezwi. 2012. Marikana: A View from the Mountain and a Case to Answer. Johannesburg: Jacana.

Baleni, F. 2012. "Baleni on Lonmin Killings and Violence (20 August)". https:// www.youtube.com/watch?v=leLzskhdYwY.

Bond, P. 2014. Elite Transition - Revised and Expanded Edition: From Apartheid to Neoliberalism in South Africa. London: Pluto Press.

Brown, J. 2015. South Africa's Insurgent Citizens: On Dissent and the Possibility of Politics. Johannesburg: Jacana.

Docimpactaward. 2016. "Winner: Miners Shot Down". https://docimpacthi5.org/ files/minersshotdown.pdf

Duncan, J. 2015. The Rise of the Securocrats: The Case of South Africa. Johannesburg: Jacana.

Duncan, J. 2016. Protest Nation: The Right to Protest in South Africa. Pietermaritzburg: University of KwaZulu-Natal Press.

Fanon, F. 1965 [1961]. The Wretched of the Earth. Translated by C. Farrington. New York: Grove Press.

Ferguson, J. 2006. Global Shadows: Africa in the Neoliberal World Order. Durham, NC: Duke University Press.

Frassinelli, P.P. 2016. "The Making and Political Life of Miners Shot Down: An Interview with Rehad Desai and Anita Khanna". Communicatio: South African Journal for Communication Theory and Research 42(3): 422-432.

Frassinelli, P.P. 2019. Borders, Media Crossings and the Politics of Translation: The Gaze from Southern Africa. New York: Routledge.

Giroux, H. 2015. "Totalitarian Paranoia in the Post-Orwellian Surveillance State". Cultural Studies 29(2): 108-140.

Hall, S. 2013. "The Spectacle of the 'Other'”. In S. Hall, J. Evans and S. Nixon (eds.), Representation (2nd edition), 225-279. Thousand Oaks, CA: Sage.

Marikana Commission of Inquiry. 2015. Marikana Commission of Inquiry: Report on Matters of Public, National and International Concern Arising Out of the Tragic Incidents at the Lonmin Mine in Marikana, in the North West Province. https:// www.sahrc.org.za/home/21/files/marikana-report-1.pdf.

Morrison, T. 1995. "The Site of Memory". In W. Zinsser (ed.), Inventing the Truth: The Art and Craft of Memoir (2nd edition), 83-102. Boston, MA and New York: Houghton Mifflin. 
Moyer-Duncan, C. 2019. "Resistance Documentaries in Post-apartheid South Africa: Dear Mandela (Kell and Nizza, 2012) and Miners Shot Down (Desai, 2014)". Journal of African Cinemas 11(1): 47-67.

Nzimande, B. 2012. "Our Condolences and Sympathies to the Marikana and Pomeroy Victims". Umsebenzi 23 August. https://www.sacp.org.za/main.php?ID=3724.

Oboe, A. 2014. "Returning Images: Mandela, Marikana and the Rugged Road to the Future". Altre Modernità 12: 1-14.

Peyper, L. 2016. "Cyril Ramaphosa Selling McDonald's SA to Foreign Firm”. Fin24 21 September. https://www.fin24.com/Companies/Retail/cyril-ramaphosaselling-mcdonalds-sa-to-foreign-firm-20160921.

RDP (The Reconstruction and Development Programme). 1994. The Reconstruction and Development Programme (RDP): A Policy Framework. https://www. sahistory.org.za/sites/default/files/the_reconstruction_and_development_ programm_1994.pdf

Saul, J.S., and P. Bond. 2014. South Africa: The Present as History. From Mrs Ples to Mandela \& Marikana. Johannesburg: Jacana.

Schutte, G. 2014. "Miners Shot Down' an Unequal Representation of the Bigger Picture". Mail \& Guardian 22 August. https://mg.co.za/article/201408-22-miners-shot-down-where-have-all-the-women-gone/.

Sinwell, L., T. Lekgowa, B. Mmope, and B. Xezwi. 2012. 'Introduction: Encounters in Marikana'. In P. Alexander, B. Mmope, T. Lekgowa, L. Sinwell and B. Xezwi (eds.), Marikana: A View from the Mountain and a Case to Answer, 1-14. Johannesburg: Jacana.

Strauss, H. 2016. "Managing Public Feeling: Temporality, Mourning and the Marikana Massacre in Rehad Desai's Miners Shot Down". Critical Arts 30(4): 58-73.

Thamm, M. 2014. "Miners Shot Down: The Film Every South African Should See, and Never Forget". Daily Maverick 4 June. https://www.dailymaverick.co.za/ article/2014-06-04-miners-shot-down-the-film-every-south-african-should-seeand-never-forget/

Wasserman, H. 2015. "Marikana and the Media: Acts of Citizenship and a Faith in Democracy-to-Come”. Social Dynamics: A Journal of African Studies 41(2): $375-386$.

Wilson, S. 2014. "Op-Ed: After Marikana Commission - What Now?" Daily Maverick 26 November. https://www.dailymaverick.co.za/article/2014-11-26op-ed-after-marikana-commission-what-now/.

Wilson, S. 2015. “Judge Farlam's Accidental Massacre”. Daily Maverick 26 June. https://www.dailymaverick.co.za/opinionista/2015-06-26-judge-farlamsaccidental-massacre/.

\section{Filmography}

Desai, R. 2015. Miners Shot Down. South Africa.

Desai, R. 2016. The Giant Is Falling. South Africa.

Desai, R. 2018. Everything Must Fall. South Africa.

Kell, D. 2016. Imbokodo: The Widows of Marikana. South Africa.

Kell, D., and C. Nizza. 2012 Dear Mandela. South Africa/United States.

Orderson, K. 2018. Not in My Neighbourhood. South Africa/USA/Brazil.

Rasethaba, L. 2016. The People versus the Rainbow Nation. South Africa.

Saragas, A. 2017. Strike a Rock. South Africa. 


\title{
6 Remembering and memorialising
}

\author{
The efficacy of photography \\ in political communication in \\ postcolonial Africa
}

\author{
George Nyabuga
}

\section{Introduction}

Photography has been a key component of effective and affective political communication in postcolonial Africa. This is largely because a "photograph passes for incontrovertible proof that a given thing happened. The picture may distort; but there is always a presumption that something exists, or did exist, which is like what's in the picture' (Sontag, 2014, p. 5). In essence, photography, its use, appreciation and interpretation in postcolonial Africa, has allowed people to identify with specific modes of agency, subjectivity, and intentionality in political and democratic processes. Granted, photography oftentimes reveals deep-seated challenges with decolonisation, particularly because most African countries are still unstable and fragile many years after independence (Ake, 1985; Cheeseman, 2015; Christensen and Laitin, 2019; Hino et al., 2012; Kier, 2007; Mbaku, 1997). Even in the postcolonial era, it is clear that

the state in Africa is plagued by a crisis of legitimacy because of its external dependence, and the decision of the political class to inherit the colonial socioeconomic system instead of transforming it ... and the use of force to repress a rising tide of resentment against the failures ... the mismanagement of development, and the impoverishment of the masses.

(Ake, 1985, p. 2)

Even though Ake's description of Africa seems dated, it still reflects the situation in many countries. The conditions in many African countries are often used to justify the leitmotif in most photographs of and from the continent.

Photographs work in particular ways, acting as intermediaries working in particularly political-economic and historical conditions and on institutional structures of signification, domination and legitimation within the wider media industry. The meanings they represent and reproduce

DOI: $10.4324 / 9781003111962-6$ 
are based on various factors, including context, and the relationship between the reader and the subject. In the context of political communication in postcolonial Kenya, pictures offer both evidence and common vantage point from which people perform or engage with "rational" and "affective" discursive reasoning and communicative actions in the public sphere (cf. Habermas, 1989/1962). In addition, they bring people 'together qua participants in a common act of focusing' (Taylor, 1985, p. 260) on political communication, both mediated and face to face, despite the aporetic presumptions in some discourses within national and global public spheres.

However, a closer inspection of political photography generates various complications and questions. For example, does political photography give the whole picture of various phenomena? Does political imagery represent the "truth"? What is the meaning of pictures in different political, historical and cultural moments in postcolonial Africa? Do photographs offer evidence necessary for rational discussions in the public sphere in which members of the public are supposed to be informed, authoritative, free and equal interlocutors? Are careful framing and editing meant to influence political events, actions and communication? What are the political narratives that emerge from pictures as creative decolonial forces of resistance? How are we to understand and narrate protest photography in the context of postcolonial politics in Kenya in what we may also refer to as postnational in which the colonial is past? These questions become even more important in the context of Kenya's postcolonial political history where "predator elites" seem to use oppressive means to subjugate "hapless peasants" in their attempt to ascend to, capture or retain power (cf. Mustapha, 2012) and thus can manipulate photography as part of their propaganda. Besides, as Mustapha (2012, p. 40) contends, the fact that 'contemporary African democratisation ... has not sufficiently engaged the ordinary citizenry in the sort of negotiations necessary to embed democratic values within the social fabric' means people have to find alternative ways of engaging in meaningful or relevant political communication that resonates with their own realities in a multiplicity of arenas where the production and negotiation of meanings take place.

Even though this chapter is based on the work of popular photographer and social justice activist, Boniface Mwangi, it contends that the use of photography in postcolonial Africa is important in political communication, mobilisation and action, and ultimately in the development and consolidation of participatory "democracy" and associated principles like accountability and the rule of law. It locates arguments within the ambit of political photography and "photography of resistance" whose meanings are drawn from their capacity to incite action and change in postcolonial Africa. The chapter starts by briefly looking at the life of Mwangi before discussing photography's place in modern political communication. 


\section{The story of Boniface Mwangi}

\section{MINOLTA}

When you are the camera and the camera is you.

- advertisement (1976) (cited in Sontag, 2014, p. 145)

Boniface Mwangi (born 10 July 1983), sometimes simply known as Boni, has been involved in serious political and social activism for years. For his passion for protest against injustice, corruption, poor political and economic governance, human rights violations, etc., he has earned the label "new revolutionary" (Odhiambo, 2018). The label reflects his incessant public and online protests against a range of mostly socio-political but also economic challenges in postcolonial Africa.

As a photographer and photoactivist, Mwangi started to gain traction with his images of the victims of Kenya's post-election violence (PEV) of December 2007-January 2008 following the disputed presidential vote of 2007. After the chaos that left more than 1,300 people dead and tens of thousands displaced (Human Rights Watch, 2008; Jérôme, 2009), he became popular for publishing and sometimes publicly displaying disturbing and unpalatable images of the victims of the violence. Due to the sensitivity of the ethnic violence, and to reduce stress and trauma in Kenya, editors at Standard Group where he worked as a photographer refused to publish some of his photographs, particularly those captured the butchery, savagery and mutilation of people. To the editors, to publish such images would have contributed to further trauma and suffering to those directly and indirectly affected. This was also part of promoting "peace journalism" (cf. Keeble, Tulloch and Zollman, 2010; Lynch, 2008; Lynch and McGoldrick, 2005; Youngblood, 2017) meant to save Kenya from further acts of violence occasioned by electoral fraud and dispute and ethnic tensions. Peace journalism, according to Youngblood (2017), avoids inflammatory language and texts that can fuel conflict. To avoid fuelling violence, Youngblood (2017, pp. 5-7) suggests that peace journalists should ideally 'thoughtfully select the images they use, understanding that they can misrepresent an event, exacerbate an already dire situation, and re-victimize those who have suffered'.

The decisions not to publish pictures of victims of the PEV contributed to his departure from mainstream media to found what he calls alternative spaces to showcase or exhibit and share his work. He sets up Picha Mtaani ${ }^{1}$ which he describes as a travelling photography exhibition showcasing images of the violence that he had witnessed and captured. ${ }^{2} \mathrm{He}$ claims the exhibition attracted more than two million people and 'offered a platform for individual reflection, honest dialogue, interpersonal healing and community reconciliation'. ${ }^{3}$ The pictures covered a wide spectrum of possibilities, from suffering to anarchy, violence, police brutality, etc. This provided not only the nexus of national and global public sphere at which discourses of postcolonial political action could be discussed but also evidence for 
advocating for social and political change. What's more, photography and social media capture and memorialise events, and somewhat become agents of action and change in political and democratic processes. Indeed, there are suggestions that:

[M]emory is not only susceptible to changes, it is itself a powerful agent of change [original emphasis]. Accredited with the power of transforming our relationship to the past and the ability to revise former values and attitudes, memory can create new frames of action. By working through past hatreds and resentments, memory can contribute towards reconciliation and new forms of co-existence, opening up the possibility of a common future. ... Personal memories are purely virtual until they are couched in words or images in order to be communicated.

(Assmann and Shortt, 2012, p. 4)

Besides, as Gloviczki (2015, p. xvii) argues, 'in the age of social media ... the memorial is interactive and ongoing'. In essence, social media offers memory and remembering longevity that may be lost in physical spaces and traditional media. He further contends that

the process of remembering can span space and time in a way that turns a seemingly private event into a much broader, more public conversation. The stories of which our lives consist have more potential to be retold and even reshaped in remembrance.

(Gloviczki, 2015, p. xvii)

This is part of public, collective memory which is played out in exhibitions whether online or offline - that Mwangi and Pawa254 organise. ${ }^{4}$ By exhibiting the pictures in public spaces, Mwangi and Pawa254 not only invite people to partake in remembering and reflective exercises, and discourses on various issues or subjects captured and represented in the images that reflect the current conditions in postcolonial Africa. Such exhibitions become part of the public sphere at which critical debate on the condition of the postcolonial state takes place. The discussions that emerge from such platforms help (re)configure memory, evoking new meaning on various issues such as violence, ethnicity, repression and power in postcolonial Africa.

Whether the public displays and political discourses emerging from such exhibitions and platforms can do justice to especially the victims of violence or conflict is another matter altogether. Nevertheless, the pictures preserve memory for posterity, offering opportunities to look back, memorialise and remember. Granted, there are compelling arguments that forgetfulness can be palliative (Assmann, 2012). Thus, curating and sharing pictures for popularity, self-promotion or aggrandisement or commercial purposes does little or harm to the healing process especially in conflict and post-conflict environments and situations. However, as Assmann (2012, p. 57) contends, 'forgetting and remembering, can exert both damaging and healing effects' 
and whatever one or society chooses is contingent upon 'historical context and above all on the cultural values and general circumstances prevailing in each instance'. In short, whether to remember or forget is an individual prerogative based on such important factors as historical contexts, cultural values and prevailing circumstances. However, some people would often rather forget any suffering they, their family or friends have encountered or suffered either directly or indirectly. Thus, regular use or public exhibition of their pictures may contribute to further or prolonged psychological suffering or trauma. This gives little comfort to the notion of pictures as memory, and calls for a rethink of exhibition and sharing or dissemination of pictures of conflict, violence and suffering. It is thus evident that there is some 'presentness and politicization of memory' (Radstone and Schwarz, 2010 , pp. 2-3) that is sometimes problematic in different situations and circumstances because the 'practices of memory and the practices of politics are compacted and difficult to unravel'.

However, the fact that photography goes through a process of careful composition and selection before exhibition or use in the public sphere calls to attention the issue of manipulation and propaganda, and thus the quality of debate.

\section{Photography, composition and framing}

The character of Kenya's troubled postcolonial political history and polarised ethnic environment marked by recurring political and ethnic tensions and violence is captured in numerous photo projects, documentaries, exhibitions and essays. By focusing on such issues as violence, human rights abuses, under-development, etc., Mwangi's pictures have acquired their political currency mainly because they offer evidence upon which public opinion is based, mobilised and legitimised. Pictures evoke different memories in different people depending on various subjects, contexts, historical moments, political or social events, and gender, age, ethnicity or cultural background among others. However, pictures can be said to be polysemic or connotative because of the different and numerous possible meanings they evoke (cf. Hall, 1973). In other words, photographs are subject to multiple interpretations and meanings, depending on people's experiences, knowledge, proximity to and relationship with the issues or subjects, and ideology, among others (cf. Hall, 1973). In fact, as Assmann and Shortt (2012, p. 4) argue, what people

encounter as reality is in fact the product of an act of interpretation.... Disseminated by the mass media as interpretations or official definitions of historical events, representations are a powerful element in the construction, contestation and reconstruction of individual and collective memories.

Accordingly, pictures of PEV victims, for example, arouse different meanings and actions from disparate actors in contested political actions. 
Granted, some of the pictures of the 2007-2008 post-election conflict and violence evidence levels of tensions between communities and electoral violence. Photography is thus seen as a powerful agency for political communication and messaging in Kenya.

However, the careful framing of the pictures is seen as part of the selective emphasis of the contents and possible political and other meanings contained in the photographs. However, more interesting to media and audiences is conflict, violence and poverty leitmotif in the pictures given those are the causes close to not only Mwangi's photography but also his sociopolitical activism and communication. Thus, while Mwangi's photography resonates with some people, the pictures may seem to pander to Western stereotypical view of Africa as a- "dark continent". Mwangi, however, denies that that his intention. He points out that his pictures reflect and represent the current "African realities" and the "bitter truth that the African leadership, the people and countries must always confront'.

While this chapter does not suggest that the pictures go through a careful framing process, there is no denying the fact that photography has intended and negotiated meaning (cf. Hall, 1973). Granted, photographers, like other content producers, always think critically or carefully about what messages and meanings their pictures seek to communicate. "Framing means bias to me", says Mwangi. 'I have a bias for the issues I feel passionate about and framing reflects what I want to advance, and the messages I want to communicate. My messages are always reflected in the images I want to capture. ${ }^{6}$ This assertion somewhat supports theoretical arguments that framing is concerned with the selection or choice of texts, and emphasis. This is the reason why framing theory has its origin in photography and cinematography (cf. McCombs and Ghanem, 2001). The choice also involves (careful) exclusion of some subjects or issues and de-emphasis of what the photographer thinks is irrelevant and unhelpful to the messages Mwangi wants to communicate and the causes and ideologies he seeks to advance. Whatever the case, however, photographers often have little or no control over audience interpretation. As Barthes (1977; see also Burke, 2010) contends, readers must always separate works from their creators in order to liberate the text from "interpretive tyranny". In other words, it is difficult or even impossible to impose a limit on interpretation. In the context of conflict and violence situations in postcolonial Africa, there are various agendas that photography seeks to represent, mediate and advance, sometimes in order to "sway public opinion and trigger action".

\section{Photography, resistance and "artrising"}

There is evidence that photography has been used effectively as modes of resistance because of the emotions they evoke. Pictures are particularly powerful "visual weapons" (cf. Lilleker, Veneti and Jackson, 2019) against oppression and suffering as has been demonstrated in places like South Africa and 
Palestine. Google Arts and Culture posits that 'of all art mediums, photography is perhaps the greatest weapon against exposing and calling to order injustice. A photograph has a sense of immediacy and cannot be denied'. ${ }^{8}$ Two examples illustrate this. The first is Afrapix, a joint activist group made up of black and white photographers who worked under apartheid during the 1980s (Krantz, 2008). The second is Activestills set up in 2005 by Israeli, Palestinian and international documentary photographers 'out of a strong conviction that photography is a vehicle for social and political change' (Maimon and Grinbaum, 2016, p. 31). The Activestills photographers view themselves 'as part of the struggle against all forms of oppression, racism, and violations of the basic right to freedom' (Maimon and Grinbaum, 2016, p. 31).

The aforementioned photographic typology has acquired numerous labels like "resistance" or "struggle photography" whose "intention ... is to document the conflicts between oppressors and their victims so as to alert, persuade, and elicit support for the oppressed. The reality captured by the photograph is from the vantage point of the subjugated person' (Krantz, 2008, p. 290).

In South Africa, Afrapix photographs documented among other issues the violence and confrontations between the people and the police and the lives of the Black people during the apartheid era. The photographs 'contributed to the culture of struggle that played such an important role in mobilizing local and international response against repression of the country's vast majority Black population by the apartheid regime' (Krantz, 2008, p. 290). Similarly, Activestills documents various cases among them, 'Palestinian popular struggle against the Israeli occupation, rights of women, LGTBQ [lesbian, gay, bisexual, transgender, and queer/questioning], migrants and asylum-seekers, public housing rights, and the struggle against economic oppression' (Maimon \& Grinbaum, 2016, p. 31).

Mwangi's Picha Mtaani and Pawa254 initiatives follow the same trajectory, although he calls his work "artrising". Artrising is described as photographic art meant to raise awareness and provoke action against various socio-political and economic challenges facing Kenya. ${ }^{9}$ Using the artrising project, Mwangi has captured images of victims of violence perpetrated by the police, vigilante groups and others. His photographs of the 2007/2008 PEV and Mungiki ${ }^{10}$ showcase a wide spectrum of issues, from police brutality to ethnic tensions, chaos and anarchy. Pictures of chopped-off limps and mob-lynching are his common subjects. They are offensive as they are provocative so 'that people can be angry enough to take action'. ${ }^{11}$ The same applies to the Diaper Mentality Project which he says was meant to reflect the "immaturity" and "stunted growth" in postcolonial Kenya. The project, using people wearing diapers,

was aimed as being the conscience of society through illustration of bad Kenyan habits with the aim of exposing them so that people can see the need to change. Diaper mentality was an attempt to focus a gaze on the microscopic features that give identity and character to Kenya. ${ }^{12}$ 
However, the diaper mentality imagery is subject to various interpretations. The "struggle for meanings" (Hall, 1980) in photography is often based on various factor including discourses, representations and ideologies that photographers seek to advance. In the decolonial context, photography is seen as a way of capturing, evidencing and communicating repression, human rights abuses and failure of power that define many African countries (cf. Ake, 1985; Cheeseman, 2015; Kieh Jr., 2007). The failure of the African state is aptly captured in the Preface of the edited book Beyond State Failure and Collapse: Making the State Relevant in Africa. In that piece, Kieh Jr. (2007) writes that:

... The African people's hopes and aspirations for a democratic, stable and prosperous post-independence era have been shattered.... After more than four decades of independence, the postcolonial project has been enveloped in a multidimensional crisis of underdevelopment - cultural, ecological, economic, political, social, and so forth. Perpetuating this crisis, illegitimate regimes and ethnic entrepreneurs have manipulated primordial differences; ... both civilian and military despots have repressed and suffocated society and basic human needs have not been met. ... The popular collective mirror image that the African masses have of the state is that of a brutal, repressive, predatory and anti-people apparatus.

(Kieh Jr., 2007, p. 9)

Kieh Jr's (2007) statement not only reflects the conditions obtaining in the many postcolonial African countries but also perhaps influences the contents of photography of and from the continent. They also inform various representations and discourses of Africa on various political arenas, including the ubiquitous social media.

Indeed, political and protest photography, social media and protest movements have attracted great public and scholarly attention, examination and debate in postcolonial Africa. This can be illustrated by recent events across the world that demonstrate the influence of photography in transnational public sphere and attendant political action and change. For instance, the Arab spring - the wave of protests, uprisings and unrest that spread across Arabic-speaking countries in North Africa and the Middle East - documented and shared by mobile devices perhaps best demonstrate the power of protest photography and transnational social movements. The debatable labelling of the Arab Spring as "Facebook revolution" (or even "Twitter revolution") further points to the capacity of photography and social media to ferment or spur protests and attendant action or change (cf. Laremont, 2014; Porta and Sidney, 2005).

\section{Conclusion}

Photography is a critical element in documenting, historicising, memorialising and remembering in Kenya's postcolonial politics. A picture, as the cliché puts it, is worth a thousand words. Well-taken and framed pictures 
are able to capture the attention and interest of audiences irrespective of their geographical location in what is now an information and networked global village and global public sphere.

While Mwangi, just like other photographers, is able to control or choose the subjects and issues selected for inclusion, places and spaces of publication, modes of circulation, dissemination or sharing, he is not in control of the meanings generated by disparate audiences whose relationship with and understanding of political issues differs. In other words, the meanings derived from the pictures are entirely those of the receiver or reader whose interpretation depends on various factors including context, historical moment(s), socio-political and economic conditions, gender and ethnicity or background.

Furthermore, as this chapter contends, memory creates new frames of action and becomes a powerful agent of political communication and change in postcolonial Africa. This is especially in the context of reformative and revolutionary social movements in a networked information society. What's more, the use of social media to both curate and communicate visual texts means they are able to be instantly received and read in different parts of the world. It could thus be said that the pictures rouse Kenyans and others around the world to action. The Arab Spring and Facebook and Twitter "revolutions" are good exemplars of the power of protest photography, instant virtual communication, networking and transnational movements. Even though Facebook or Twitter revolutions are still to happen in Kenya, there are some examples to illustrate the mobilising capacity of such platforms given the fact that protests or demonstrations are increasingly being organised via such channels. The growing appropriation of social media platforms due to the availability and affordability of such devices as smartphones, mobile devices and the Internet makes taking, sharing and using pictures for mobilisation for various causes and action much easier. In addition, social media, as democratic and alternative spaces, provide the necessary tools and opportunities for immediate virtual communication. Viewed through the lenses of political communication, the ability of social media to decolonise communicative spaces is vital for photography-supported social movements that seek to promote various causes including justice, human rights, and fights against bad political and economic governance. Besides, pictures offer the evidence necessary to push such agendas.

Despite the above assertions, however, it is important to critically interrogate the place and efficacy of photography in memorialisation, remembrance and forgetting in different arenas or environments in postcolonial Africa. This begs several questions. Are people to remember events because of "coded" and "framed" pictures? Can the pictures aid or support "genuine" remembrance or is the framing used to advance certain political agendas, and influence or even sometimes manipulate public opinion and action both in national and global public spheres? These questions are important because mediated pictures of poverty, conflict, violence, poverty and general suffering seem to interest people around the world, and Western media and audiences have used such images to advance and even reinforce historical stereotypical perceptions and narratives of postcolonial Africa as a "dark" continent. 
It is also vital to enquire whether forgetting is more important in conflict and post-conflict situations and environments. In such settings, pictures of suffering and misery can be damaging to individuals and societies which have gone through traumatic experiences. For, as Assmann (2012, p. 57) contends, "forgetting and remembering, can exert both damaging and healing effects" in postcolonial Africa where "predator elites" seem interested in using photography as propaganda and "hapless peasants" as evidence of their socio-political and economic conditions. Whatever individuals and societies choose is of course determined by various factors including historical contexts, cultural values and prevailing circumstances (Assmann, 2012, p. 57). Another question worth pondering is whether the "realities" the pictures capture are empirically "true". This is especially controversial given the fact that photography is framed and coded, and might be used to drive certain agendas, and influence particular narratives and ideas especially about postcolonial Africa in Western countries. In an era of fake news, "alternative" truths, misinformation and disinformation, such questions cannot be disregarded. Indeed, prevailing conventional wisdom demands that the readings and meanings of messages in photography are contingent upon careful examination of the agendas and ideologies present in any texts particularly in mediated national and global public spheres and in the political communication and advocacy domains. It should be noted that in autocratic and "pseudo-democratic" countries, protest photography often runs afoul of a predator leadership elite who often sees it as a form of challenge to power and status quo.

Whatever the case, however, there is no doubt that to document history is important for posterity, as future generations will have photo evidence upon which to base their understanding, memorialisation and remembrance of their societies, their past, and past events in postcolonial Kenya and Africa. What's more, photography like other visual texts seems to capture people attention and somewhat influence their position in public communications and engagement within the public sphere in postcolonial Kenya.

\section{Notes}

1 Literally translated from Swahili to English, Picha Mtaani means pictures in the community or community pictures. However, this has a much deeper meaning, depending on the memorialisation and remembrance context. The involvement of ordinary members of society means the pictures resonate with their socio-political and economic conditions, causes that Mwangi captures and promotes.

2 See Boniface Mwangi's website, https://www.bonifacemwangi.com/, for more details.

3 Personal phone interview with Mwangi, 17 February 2020.

4 Pawa is a sheng (a local language mixing Swahili and English words) word for 'power' while 254 is international code for Kenya. See the Pawa254 website https://pawa254.org for more details.

5 Personal phone interview with Mwangi, 17 February 2020. 
6 Ibid.

7 Ibid.

8 See Google Arts and Culture. The Evidence of Things Not Seen: Photography and Resistance, n.d. Available at <https://artsandculture.google.com/exhibit/ the-evidence-of-things-not-seen-photography-and-resistance- $\% \mathrm{C} 2 \% \mathrm{~A} 0$ johannesburg-art-gallery/oAJScEI-O01qKQ?hl=en>.

9 Personal phone interview with Mwangi, 17 February 2020.

10 Mungiki is a vigilante group whose origin goes back to the struggle for independence in 1950s. It has in recent years metamorphosised into a criminal gang known for extortion and murder. It was reported that the gang killed at least 43 people - beheading several of its victims, mainly in Nairobi slums and central Kenya in March 2007. It was banned by the government in 2002, and since then regular police crack downs are carried out in attempts to wipe it out. In the process, the police often shoot its adherents, and Mwangi has been at hand to capture some of the police operations in different parts of the country.

11 Ibid.

12 Ibid.

\section{References}

Ake, Claude. "The State in Contemporary Africa". In Political Economy of Nigeria edited by Claude Ake, 1-15. Lagos: Longman, 1985.

Assmann, Aleida. "To Remember or to Forget: Which Way Out of a Shared History of Violence?" In Memory and Political Change, edited by Aleida Assmann and Linda Shortt, 53-71. Houndmills, Basingstoke: Palgrave Macmillan, 2012.

Assmann, Aleida and Linda Shortt. "Memory and Political Change: Introduction." In Memory and Political Change, edited by Aleida Assmann and Linda Shortt, 1-14. Houndmills, Basingstoke: Palgrave Macmillan, 2012.

Barthes, Roland. "The Death of the Author." Image Music Text (essays selected and translated by Stephen Heath), 142-148, London: Fontana Press, 1977.

Burke, Seán. The Death and Return of the Author: Criticism and Subjectivity in Barthes, Foucault, and Derrida. 3rd ed. Edinburgh: Edinburgh University Press, 2010.

Cheeseman, Nic. Democracy in Africa: Successes, Failures and the Struggle for Political Reform. New York: Cambridge University press, 2015.

Christensen, Darin and David Laitin. African States Since Independence: Order, Development, and Democracy. New Haven, CT: Yale University Press, 2019.

Gloviczki, Peter Joseph. Journalism and Memorialization in the Age of Social Media. New York, NY: Palgrave Macmillan, 2015.

Habermas, Jürgen. The Structural Transformation of the Public Sphere: An Inquiry into a Category of Bourgeois Society, translated by Thomas Burger with the assistance of Frederick Lawrence. Cambridge: Polity Press, 1989/1962.

Hall, Stuart. "Cultural studies and the Centre: Some Problematics and Problems". In Culture, Media, Language: Working Papers in Cultural Studies, 1972-79, edited by Stuart Hall, 2-35. London: Hutchinson, 1980.

Hall, Stuart. Encoding and Decoding in the Television Discourse. Centre for Cultural Studies, University of Birmingham, 1973.

Hino, Hiroyuki, John Lonsdale, Gustav Ranis and Frances Stewart, eds. Ethnic Diversity and Economic Instability in Africa: Interdisciplinary Perspectives. Cambridge: Cambridge University Press, 2012. 
Human Rights Watch. Ballots to Bullets: Organized Political Violence and Kenya's Crisis of Governance. New York: Human Rights Watch, 2008, https://www.hrw. org/sites/default/files/reports/kenya0308web.pdf.

Keeble, Richard, John Tulloch and Florian Zollman, eds. Peace Journalism, War and Conflict Resolution. New York: Peter Lang, 2010.

Kieh Jr., George Klay, ed. Beyond State Failure and Collapse: Making the State Relevant in Africa. Lanham, MD: Lexington Books, 2007.

Kieh Jr., George Klay. "Preface". In Beyond State Failure and Collapse: Making the State Relevant in Africa, edited by George Klay Kieh Jr., ix-x. Lanham, MD: Lexington Books, 2007.

Krantz, David. "Politics and Photography in Apartheid South Africa." History of Photography, 32(4) (2008): 290-300.

Laremont, Ricardo Rene. "Demographics, economics, and technology: Background to the North African Revolutions." In Revolution, Revolt and Reform in North Africa: The Arab Spring and Beyond, edited by Ricardo Laremont, 15-29. Abingdon, Oxford: Routledge, 2014.

Lilleker, Darren, Anastasia Veneti and Daniel Jackson. "Introduction: Visual Political Communication”. In Visual Political Communication edited by Anastasia Veneti, Daniel Jackson and Communication Lilleker Darren, 1-13. Cham: Palgrave Macmillan, 2019.

Lynch, Jake. Debates in Peace Journalism. Sydney: Sydney University Press, 2008.

Lynch, Jake and Annabel McGoldrick. Peace Journalism. Hawthorn Press, 2005.

Maimon, Vered and Shiraz Grinbaum. "Introduction." In Activestills: Photography as Protest in Palestine/Israel, edited by Vered Maimon and Shiraz Grinbaum, 28-38. London: Pluto Press, 2016.

Mbaku, John Mukum. Institutions and Reform in Africa: The Public Choice Perspective. Westport, CT: Praeger, 1997.

McCombs, Maxwell and Salma Ghanem. "The Convergence of Agenda Setting and Framing." In Framing Public Life: Perspectives on Media and our Understanding of the Social World, edited by Stephen D. Reese, Oscar H. Gandy, Jr., and August E. Grant, 67-81. Mahwah, NJ: Lawrence Erlbaum, 2001.

Mustapha, Abdul Raufu. The Public Sphere in 21st Century Africa: Broadening the Horizons of Democratisation. Africa Development, XXXVII(1) (2012): 27-41.

Odhiambo, Tom. "If You Have a Life Story Like That of Boniface Mwangi, Please Tell It." The Nation, 15 December 2018. https://www.nation.co.ke/lifestyle/weekend/ life-story-like-Boniface-Mwangis-tell-it/1220-4896512-915gtsz/index.html.

Porta, Donatella Della and Sidney Tarrow. "Transnational Processes and Social Activism." In Transnational Protest and Global Activism, edited by Donatella Della Porta and Sidney Tarrow, 1-17. Oxford: Rowman \& Littlefield Publishers, 2005.

Radstone, Susannah and Bill Schwarz. "Introduction: Mapping Memory." Memory: Histories, Theories, Debates, edited by Susannah Radstone and Bill Schwarz, 1-9. New York: Fordham University Press, 2010.

Schauer, Pete, ed. Politicians on Social Media. New York: Greenhaven Publishing, 2014.

Sontag, Susan. On Photography. London: Penguin Classics, 2014.

Taylor, Charles. "Theories of Meaning." In Human Agency and Language. Philosophical Papers I, edited by Charles Taylor, 248-292. Cambridge: Cambridge University Press, 1985.

Youngblood, Steven. Peace Journalism Principles and Practices: Responsibly Reporting Conflicts, Reconciliation and Solutions. New York and London: Routledge, 2017. 


\title{
7 "Killing with kindness" \\ Political icons, socio-cultural \\ victims: visual coloniality of the \\ Siddis of Karnataka, India
}

\author{
Sayan Dey
}

\section{Introduction}

"Look at the black ugly man! Look at his skin, it's so dirty! Look at his hair, it's so burnt!"

(Lost Tribe of Africa 2018)

This is how Ramnath Siddi, a social activist from the Siddi community, who belongs to the Karwar district of Karnataka, is habitually ridiculed by the local passersby when he leaves his village and goes to the city for work. Juje Jackie Harnodkar Siddi, who also belongs to the Siddi community of Karwar district and is a central government worker in Mumbai, undergoes a similar experience on a daily basis. He says, 'If I go $50 \mathrm{~km}$ from here I am as good as a foreigner. I am branded a tourist. When I travel in trains and buses I encounter a lot of racism' (Siddis: In It For The Long Run 2016). These racial abuses are underpinned with captioned photographs and documentaries that portray them through the colonial lens as 'savages, slaves and barbarians' (Conklin 1997: 13-14). On the one hand, these documentaries and photographs have 'scientific pretentions informed by the well-ingrained dictum of bourgeoisie culture that somehow "photos don't lie"" (Gordon 1997: 6) and on the other hand, the captions successfully reproduce the epistemic values of British colonisation. It gets thoroughly reflected through the ways in which the Siddi people are documented, photographed and captioned in the contemporary era. For instance, let us look into Figure 7.2.

In the above collage, C.L. Kamat has tried to project the Siddi people of Karnataka as "exotic and pristine primitives" (Gordon 3) through specifically focusing (except Figures 7.1 and 7.2) on the facial structures, the facial expressions and the hair patterns of the Siddi people of Karnataka and stereotypically captioning them as "Indians of African Origin". In another image, Kamat once again focuses on the facial structure and the hair pattern of a middle-aged Siddi woman and captions the photograph as "Hardworking Siddi Woman". Let us look into Figure 7.3. 


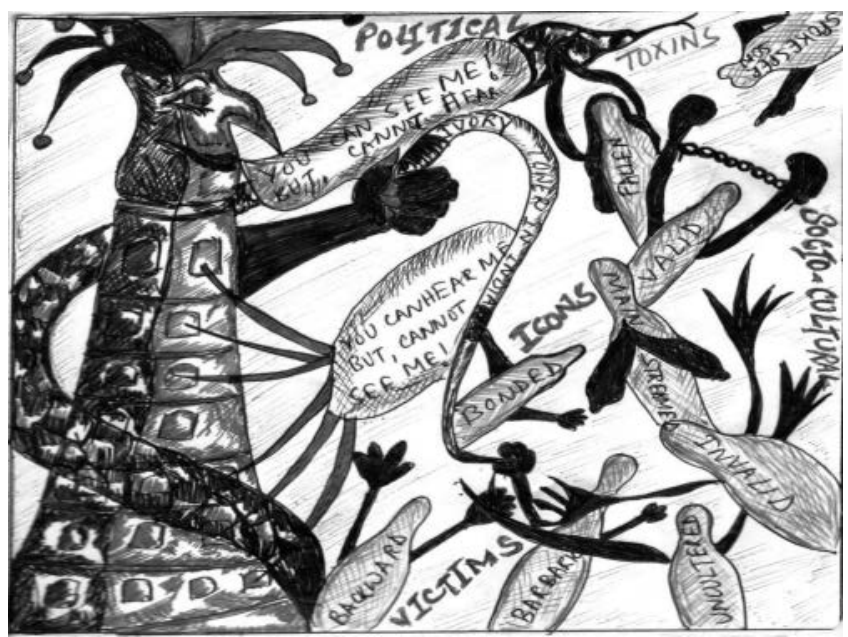

Figure 7.1 Political icons, socio-cultural victims. Copyright: Sayan Dey.

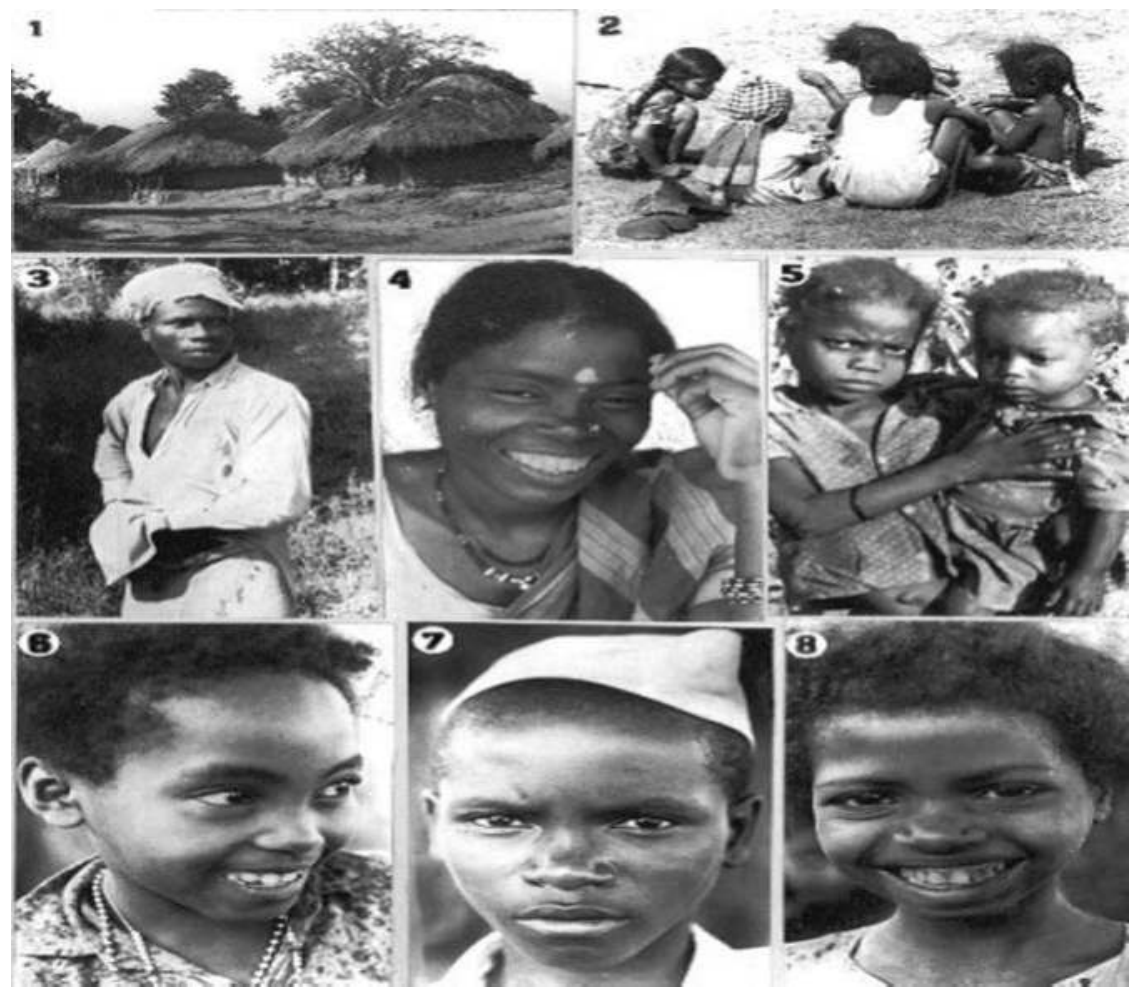

Figure 7.2 Indians of African origin. Copyright: C.L. Kamat. 


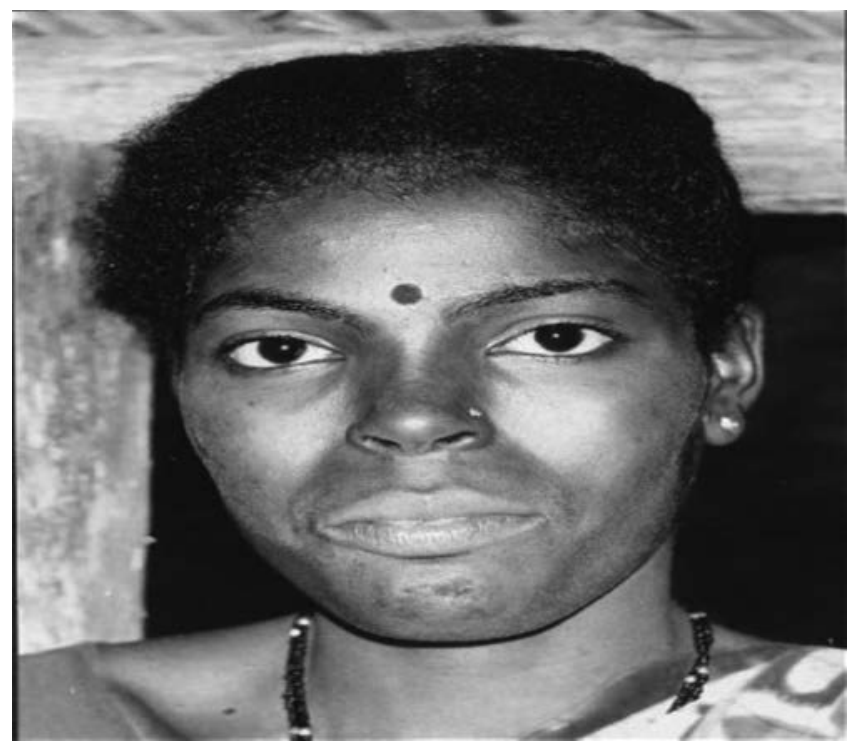

Figure 7.3 Hardworking Siddi woman. Copyright: C.L. Kamat.

Apparently, the appearance of this picture does not convey any aspect of her being hardworking, but the caption suggests what should be 'attended and in what light this aspect ... is to be seen' (Goffman 1979: 14). Captions impregnate a photograph with 'a culture, morality and an imagination' (Barthes 1985: 54). This is how a visual narrative is safeguarded by the colonially engineered colossus of "imagicides" and "ontocides". ${ }^{1}$ Imagicides and ontocides assist the photographers in "authenticating the truth claims made for individual photographs, especially within the emerging mass media' like social networking sites, newspaper/tabloid/magazine articles and blog archives (Sekula 1992: 374). It can be prominently observed through the photographic projection of the Siddi community in India. With respect to these arguments, this chapter explores the intentions, processes and the impact of visual coloniality that the Siddi community of Karnataka and Gujarat habitually encounters in the contemporary era. This chapter also analyses the various initiatives that the Siddis have adopted to decolonise their visually colonised socio-cultural narratives.

The chapter is divided into three sections. The first section, 'Sociohistorical origin of the Siddi community in India: an overview', reflects upon the origin of the Siddi community in India and due to lack of sufficient written documents, the socio-historical stories are mostly based on the oral narratives of the Siddis. The second section titled "Political icons/sociocultural victims: the irony of the colonial gaze" argues how the individuals/institutions in collaboration with the mass media have systematically 
curated an archive of social, cultural, political and racial segregation of the Siddi community through documentaries, photographs and captions. The third section, "Conclusion: decolonising the colonial gaze through a twoway resistance", makes an effort to establish a framework of two-way resistance: "Visual Sovereignty" and "A Decolonial Archival Turn", in order to dismantle the colonised and de-contextualised myopic vision of interpreting the Siddis in India and establish de-hierarchised, decolonised and pluriversalised hypermetropic spaces of analysing them within the contexts of their respective socio-historical experiences.

\section{Socio-historical origin of the Siddi community in India: an overview}

It is usually believed that the Siddis originated from the Bantu people of eastern Africa and they arrived in India over two phases. The first phase was during the seventh century when the Arabs brought them as slaves to Gujarat. The second phase of their arrival took place around sixteenth century when the Portuguese arrived in Goa from eastern Africa and brought the Siddi people as slaves (Harris 1971: 56). The etymological origin of the term 'Siddi' is highly argumentative in nature. According to Alice Albinia, the word 'Siddi' derives from the Arabic word 'Sahibi' and it is used as a mark of respect in East Africa (Albinia 2012: 74). Vijay Prashad argues that the term "Siddi" has been derived from the Arabic word "Sayyid" and this title was "borne by the captains of the Arab vessels that first brought Siddi settlers to India' (2002: 108). With the passage of time, the term "Siddi" was also used to refer to a multiracial community in India that evolved through the amalgamation of Siddis, Indians and Portuguese people (Harris 1971: 58).

As the first group of Siddis arrived with Arab invaders at Bharuch Port, Gujarat, some of them escaped into the nearby forests of Gujarat and some of them crossed into the forest lands of Karnataka. Gradually, they established their settlements in these forests (Mitra 2018). Those Siddis who could not escape from enslavement served the Arabs in various capacities. Though, initially, they 'were used as domestic slaves by wealthy Arab families' (Padma 2019), but, with the passage of time, they were employed 'as soldiers, palace guards [and] bodyguards' (Sylviane A Diouf quoted in Vikas Pandey 2014) because they 'were generally deemed more trustworthy than indigenous people to serve in those capacities' (Schomburg Center for Research in Black Culture 2011). Apart from these slaves, Mahmood Mamdani mentions that many Siddis also independently arrived in India as "traders" and "armed African sailors" (2013: 9). In the thirteenth century, many slaves successfully revolted against their masters, disentangled themselves from enslavement and rose through the ranks to become "generals, admirals and administrators" (Diouf quoted in Vikas Pandey 2014). For instance, an Abyssinian slave named Jamal-ud-Din Yakut, who served Razia Sultan (the 
daughter and heir to Shams ud-Din Iltutmish of Mamluk Dynasty), was conferred with the title "Amir al-Umara" (Amir of Amirs), which was primarily reserved for Turkic nobles (Keay 2011: 141). He is believed to be the first Siddi to occupy a prominent position in India. In the sixteenth century, another Abyssinian slave named Malik Ambar (1548-1626) gained a reputation as a military tactician (Ali 2011). After he freed himself from captivity, he was widely celebrated among the other Siddi slaves, whom he motivated to join his army and resist the invasion of the Mughals in the Deccan. His fame and power was a major threat to the Mughal emperors.

Around the fifteenth century, Malik Ambar, along with his fellow, Sidi Ambar the Little (1621-1642), pushed ahead to establish a Siddi family dynasty in the nearby princely state of Janjira (Mcleod 2008: 256) and placed Sidi Ambar on the throne. Around the nineteenth century, the sixth Nizam of Hyderabad, named Mahboob Ali Khan (1866-1911), recruited around 300 Siddis and founded the African Cavalry Guards (Haviland 2003). By the time when these Siddis have almost unshackled themselves from slavery and have reached significant socio-cultural positions in India, especially in Gujarat and Hyderabad, the second group of Siddi people was brought to India as slaves by the Portuguese in the sixteenth century. According to Mark Pinto, an anthropologist based in Goa, 'They were brought to work as domestic slaves in Goa from Mozambique in Africa, which was also a Portuguese colony at the time' (as quoted in Bhat 2019). After slavery was abolished in all the Portuguese colonies across the world in 1869, the Siddis 'migrated to the forest areas of Karnataka, Gujarat and Maharashtra' (Bhat 2019).

After India's independence in the year 1947, certain caste and communal groups in India, ${ }^{2}$ who experienced severe colonial exploitation, were granted "special privileges" [Scheduled Castes (SCs), Scheduled Tribes (STs) and Other Backward Castes (OBCs)]. The special privileges led to the "validation" and "non-validation" of certain castes, sub-castes and communities, and their social, cultural, political and economic practices. In a similar manner, the Siddis were identified as Scheduled Tribes. Officially, they were granted reservations in education and job sectors across the country, but in reality they have been socio-culturally racialised, ghettoised and museumified. ${ }^{3}$ In spite of residing in India for several centuries, the Siddis are treated like socio-cultural outsiders. At present, the Siddis reside around the forest regions of Karnataka and Gujarat. As a result, most of them have hardly any access to schools, colleges and jobs. A few of them who manage to go to the city in search of education and jobs are regularly victimised by racial and cultural abuses. For instance, the habitual experiences of Ramnath Siddi and Juje Jackie Harnodkar Siddi which have already been shared at the beginning of this chapter. The "Siddis" are often referred to as "Hafsis" as well. The term "Hafsi" is a racial abuse which can be roughly translated as "half-humans" (Segal 2002: 84). Besides these challenges, the government and the media have been treating the community as a museum artifact. These, all 
together, nurtured a pan-Indian project of systemic, epistemic and ontological assimilation/violation of the Siddis within the colonially indoctrinated storehouses of social, cultural and racial ideologies. The ideologies consistently manufacture frameworks of segregations. The storehouses are strictly monitored by the following components: distorted government reports, halfbaked interpretations by media houses, misinterpretations through personal blogs and stereotyped, exoticised and captioned photographs, which iconise the community on the one side and victimises them on the other. With respect to the thematic relevance of this chapter, the following section will analyse how documentaries and photographs of the Siddis that are captured and captioned by the tourists (Indians as well as foreigners), non-Siddi locals, government officials and the media celebrate the racially conceptualised structures of the "colonial gaze" (Eeden 2004: 20).

\section{Political icons/socio-cultural victims: the irony lof the colonial gaze}

In the documentary The Siddis: India's Forgotten Africans (2017), during a conversation with a media representative from the United Nations, Ambassador Syed Akbaruddin, India's permanent representative to the United Nations, reveals that the Siddis of Gujarat have 'access to education in a preferential manner. They also have access to jobs in a preferential manner' (United Nations). But Imran Siddi argues: 'We get help from the government, but the help does not reach us' (United Nations). The documentary, through dresses, facial expressions, living standards and the body languages of the Siddis, makes an effort to show how the Siddis in Gujarat are prospering through various socio-economic initiatives of the Indian government which recognised them as a 'special tribe and granted them individual rights' (United Nations 2017). But, with respect to Imran's experiences, the application of the rights is highly questionable and most of the Siddis in Gujarat live in utter social, cultural and economic crisis. Another Siddi man from the Siddi community in Jamnagar, Gujarat argues that they are deprived of education. He says: 'The only problem we are having is that kids are not getting access to education' (visualpoet1, Siddis of Jamnagar 2018). The physically and socio-culturally isolated existence of the Siddi community also gets reflected in the Jambur village of Gujarat. They live in broken mud houses and have no access to education and job. According to a local activist from Jambur, the education status of the Siddi people is very poor (visualpoet1, Jambur: The African Village 2018). The Siddi community in Talala, another village in Gujarat, also undergoes an identical experience (visualpoet1, The Siddis/Habshis (African Indian) community in TALALA 2018). These experiences of the Siddis in different parts of Gujarat unfold the contradiction between the government assurances and its visual portrayal by the media on the one side and the habitual existential sufferings of the Siddis on the other. 
In a similar manner, a documentary titled RSTV Documentary - Siddis of Karnataka (2017) socio-politically iconises the community on the side and culturally victimises the community on the other. In the documentary, R.V. Deshpande, In-charge District Minister, Government of Karnataka, proudly applauds the contributions of the central and state government toward the "development" and "welfare" of the Siddis in Karnataka. He says:

I am grateful to the government and state government that they have been declared scheduled tribes now. Many schemes are being implemented for them. I am happy to tell you that most of them have their houses and they are going to schools and colleges. Slowly we are also finding postgraduates and lawyers coming out of them. So, the state government is totally committed to the welfare of the Siddis. The most important thing is that under the Government of India Tribal Act we are giving them forest rights so that they can cultivate the forest lands and all.

[(my italics) Rajya Sabha TV]

Through a narrator from the media department of the Indian government, the documentary tries to authenticate a "false narrative" by showing how the Siddis as farmers, teachers and leaders wish to desert their indigenous lifestyles and aspire to be a part of the socio-cultural mainframe. The documentary also tries to project the supportiveness of the Siddis for the various development projects of the government by sharing how much they have "advanced" in tune with the "modern Indian society" (also read as Western/ colonial/modern Indian society). I argue the portrayal of the Siddis in the documentary as a false narrative because the Siddi people, for whom these "developmental initiatives" are packaged and advertised, have different experiences to share. For instance, Ramnath Siddi reflects:

Although we live in the forest, Siddis have on-going disputes for land rights. Our local villagers are trying to force Siddis to move out. Even though we have government papers to prove land ownership, some of our neighbors do not want Siddis living near them. As a social worker, I fight to protect Siddis from land grabbing cases.

(National Geographic 2018)

The villagers believe that because the Government of India has initiated special housing schemes for the Siddis in Karnataka, they should move out of their natural habitat and hand it over to the encroaching villagers. Emmanuel Siddi, another social worker from the Siddi community of Wada district in Karnataka, unveils how the Siddis face caste, class, religious and economic marginalisation on a regular basis. He laments that in the contemporary era, their community is socio-culturally segregated through caste, religion and untouchability. 'We have to stay like a frog in a well' (Emmanuel Siddi, African Indian, visualpoet1 2018). Juje Siddi also observes 
how on the one hand the central and the state governments have granted them rights to the forest lands and on the other hand how these rights are violated by the local villagers (101 India 2016). The headman of the Siddi village of Gadoli in Karnataka talks about the socio-economic crisis that they face today. He says: 'We have been poor for the last 300 years and we are still poor' (Nzwamba 2013).

Through these examples, the sufferings of the Siddi community in different parts of Gujarat and Karnataka reflect upon how they are politically "iconised" and socio-culturally "victimised" by the colonial gaze of authentic racialised, marginalised and exoticised visual templates of violence in postcolonial India. The visual templates of violence are systematically organised through documentaries and captioned photographs. Till now, in this section, I have explored a few documentaries and analysed the various ways through which the documentaries have been visually colonising the Siddi community in contemporary India. In the following part of this section, I will be analysing various captioned photographs of the Siddis and the roles that the photographs play toward preserving and promoting visual coloniality.

Prior to the analysis of the photographs, it is necessary to understand the socio-cultural, political and economic intentions behind the visual portrayals of the Siddi community through various media. Therefore, it is also crucial to locate the time period from which the history, society and culture of the Siddis in India were documented. The documentation process flagged off with the initiation of the Special Areas Games Project (from now on SAGP) in 1987, just two years before the general elections in India. During the late 1980s, as the general election was approaching, the central government of India came up with multiple development schemes for the socio-economically backward tribal communities in India and one of them was SAGP for the Siddis in Gujarat and Karnataka. This is why, before the 1980s, documentation and archives about the Siddi community in India cannot be found. The self-centred political and racial motives behind the conceptualisation and discontinuity of the SAGP scheme also objectify why the documentaries and captioned photographs falsely project the Siddis as a socio-economically advancing and a culturally prosperous community. So, before we look into the various photographs of the Siddi community that have been captured since the 1980s, let us briefly explore how the SAGP project was developed and under what circumstances it was shut down.

During the sports minister-ship of Margaret Alva, the SAGP was launched and was implemented in Karnataka and Gujarat. The Sports of Authority of India (from now on SAI) felt that 'because of their African lineage, their natural athleticism could be used to win medals for India at world sports competitions' (Plummer 2017). So, in 1988, Sunder Raju, the athletics coach, along with other officials from SAI travelled to Gujarat and Karnataka to scout young Siddis for trials and training. During the trials, several Siddi teenagers were selected and taken to different SAI training centres across the country (Menon 1988). The initiative started delivering prompt and 
optimistic results as several Siddi athletes started proving their worth in different national, state and local competitions (101India 2016). But, in the year 1992, without any concrete reason, the project was surprisingly called off, hostels were shut down and all the Siddis were sent back. With the passage of time, it was realised that under the mask of "tribal development initiatives", the SAGP was nothing more than a failed experiment with 'genetic supremacy theory' (Janardhan and Pathak 2013). In 2017, during an interview, Juje Siddi, who was a victim of this racially and genetically violent project, said that the 'government started (this) as (a) trial...because many experiments were done' during that time (as quoted in Maturkar 2017). Apparently, this project proved to be a complete failure. But, the central government's colonially structured racialised schemes of "pseudo-development", which was the original objective of this project, received further impetus through the visual catalogs of systemically and epistemically violent photographs. These photographs continue to racially stereotype and exoticise the community even today. For example, the book of photographs by Ketaki Sheth titled A Certain Grace Sidi: The Indians of African Descent, which claims to be a 'fruitful journey of knowing them [the Siddis] and their lifestyle' (Sheth quoted in IANS 'Siddis: Little Known Indians' 2013), captures and captions the Siddis of Karnataka and Gujarat in an exotic and stereotypical manner. Let us analyse some of those photographs:

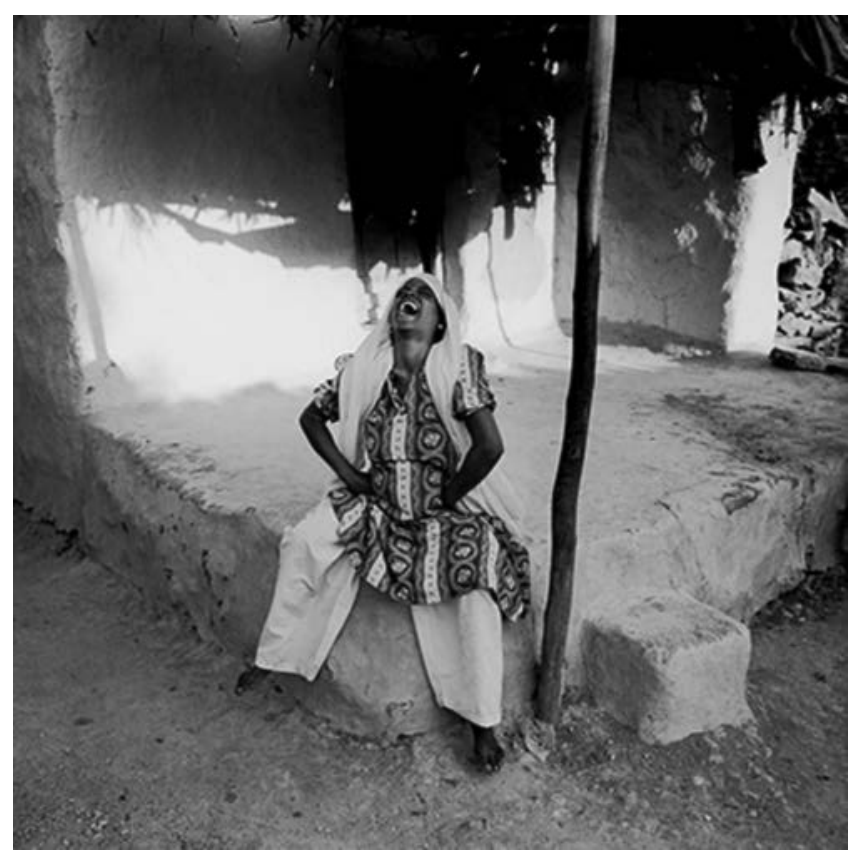

Figure 7.4 Ramzamma laughs when she is asked if she is pregnant with her first child. It is actually her fourth. Copyright: Ketaki Sheth/courtesy Photoink. 


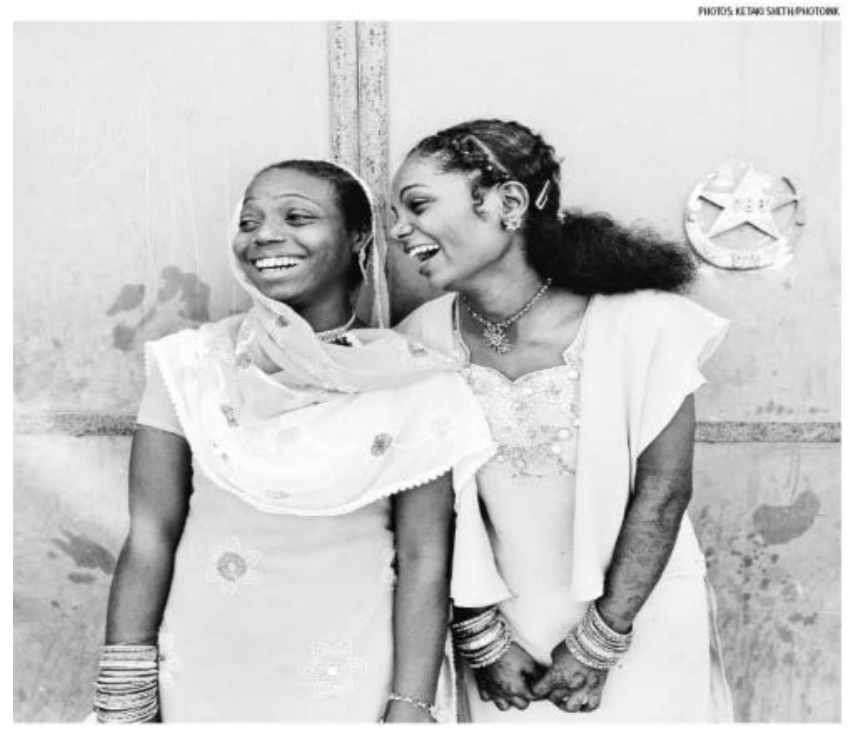

Figure 7.5 Indians of African descent. Image Copyright: Ketaki Sheth/courtesy Photoink.

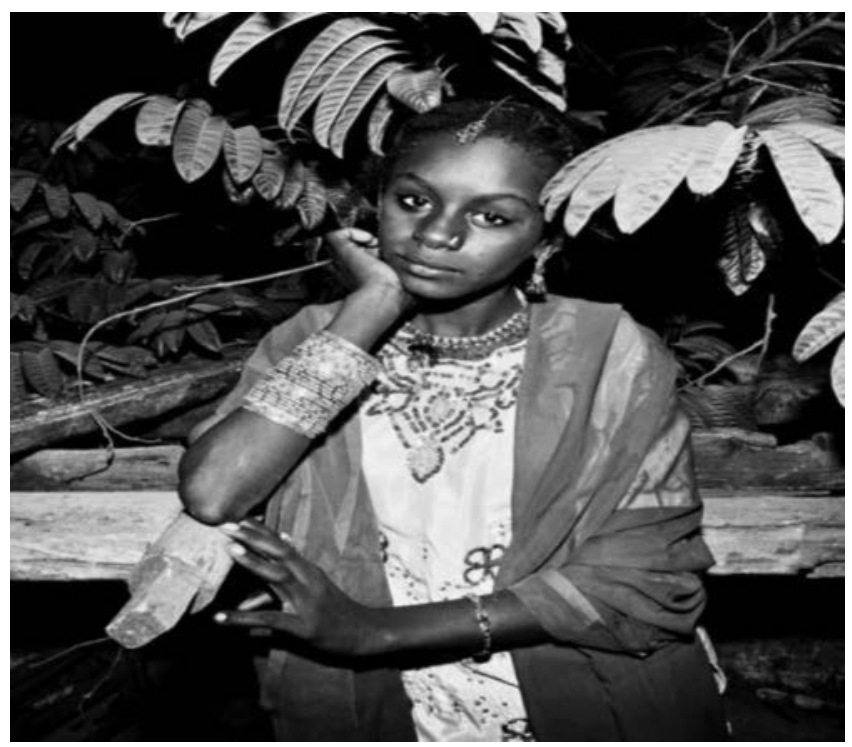

Figure 7.6 A beautiful Siddi woman. Copyright: Ketaki Sheth/courtesy Photoink. 


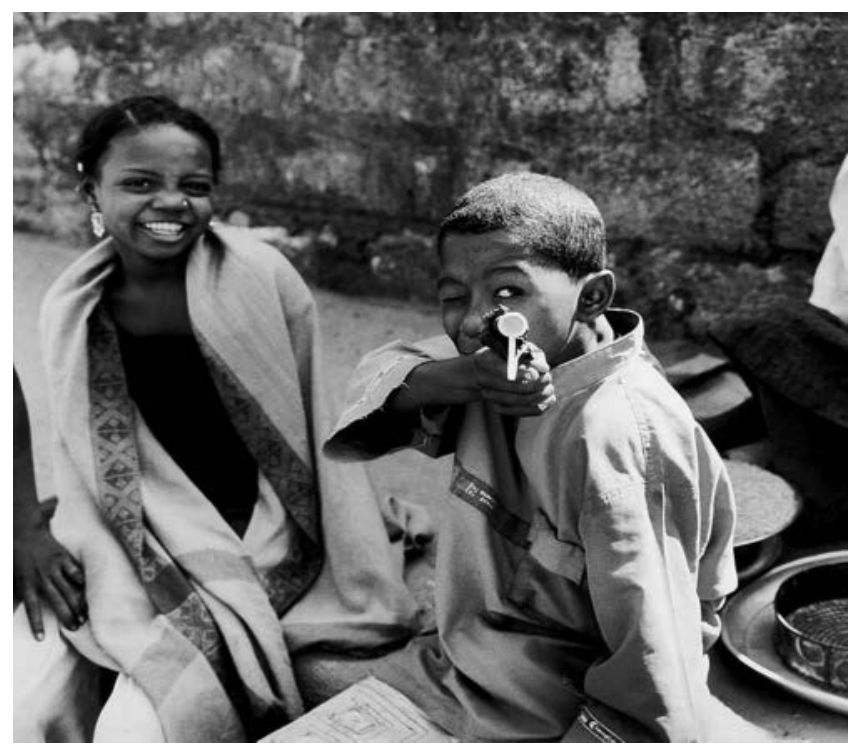

Figure 7.7 Siddi in India. Copyright: Ketaki Sheth/courtesy Photoink.

With respect to capturing the daily lifestyle of the Siddis, in Figure $7.4 \mathrm{Ke}$ taki Sheth portrays a laughing Siddi woman from Gujarat who is pregnant. Figure 7.5 focuses on two smiling young Siddi women. Figure 7.6 shows a decked up Siddi woman. Figure 7.7 upholds two Siddi kids in a playful mood. All these photographs present the Siddis as a very joyful community that has successfully "mainstreamed" and "modernised" themselves within the socio-cultural mainframe of contemporary India. Apart from these photographs, Ketaki Sheth has captured and captioned several other photographs like Siddis dressed in modern/western attires, Siddi children playing with modern/western toys, etc. While sharing her experience with IANS, Sheth philosophised:

For me, it was an accidental discovery, there are many who don't know about them. But, it is great to see how beautifully they have embraced the local language, drinks, food and religion, including Sufism, Hinduism and Christianity, without giving up their African traditions.

[(my italics) as quoted in 'Siddis: Little Known Indians' 2013]

This observation enfranchises the "colonial/racial ordering" of sociocultural practices in which the indigenous Bantu associations of the Siddis are identified as a secondary component with respect to the conformist ideologies of the mainframe Indian social structure. It gets thoroughly reflected through the manner in which she has photographed the Siddis. Out of all 
the photographs, very few portray the indigenous African practices and also they are limited to dance and music (Dhammam ${ }^{4}$ ). Most of her photographs reproduce the racial and cultural conventions, which were once practiced by the Arab and Portuguese colonisers against the Siddis. In addition to Sheth's project, several media articles and blogs also visually colonise the community in a similar pattern. It is very much evident in the article "India's African Keeps Ancient Customs Alive" (2013), which was e-paper named Dawn. Though the photographs ${ }^{5}$ in the article talks about the African cultures and traditions (specifically Bantu cultures and traditions of eastern Africa) that are practiced by the Siddis, yet the photographs appear to be completely out of context. In this way, these visual narratives of violence (documentaries and photographs), in the name of preserving and promoting the indigenous African identity of the Siddis, are "killing with kindness" and "making icons of a people whom we see as more "organic" and "in touch with the earth" (Hubbard 1994: 31). This can be thoroughly understood through these documentaries and photographs that have been organised in the form of definite 'cultural ideas and social contracts' (Ryan 1997: 65) to portray 'specific ideas and social values' (Mabry 2014: 1) in a biased manner.

But, the current Siddi residents are gradually becoming aware of distortion, polarisation and marginalisation of their society, history and culture through these captioned photographs and documentaries. They have also realised that decolonisation is not about 'grounding their identities and histories in victimhood' (Pedri-Spade 2016: 58) but to develop multiple initiatives to resist these visual colonial practices, which will be elaborated in the following section.

\section{Conclusion: decolonising the colonial gaze through a two-way resistance}

In this section, I will be discussing how the Siddis of Karnataka and Gujarat are recreating their social, cultural and historical memories by developing 'awareness of selfhood or identity' (Assman 2008: 109). The awareness of their Bantu identity and selfhood is generated by 'unsettling Eurocentric conceptions of what photographs are, their history, as well as the identities, histories, and experiences of those who are the subjects of the camera' (Bell 2008: 124). The process of unsettling to regenerate the Bantu memories of the Siddis and reclaim their memories and "cultural teachings" (PedriSpade 2016: 46) is practiced in the form of a two-way resistance which is as follows:

a Visual Sovereignty: In the year 1984, the Siddis from Wada, Karwar and Gadoli districts of Karnataka came together to establish All Karnataka Siddi Development Association (from now on AKSDA). The central objective of the association was to foster development. With respect to fostering development, the central government-sponsored SAGP was 
regarded as a prominent initiative. The AKSDA members collaborated with the government representatives in organising sports trials in their villages and assisted the Siddi children to get selected for training. But, after a certain period of time, the association realised that the government has only used them as an object of "racial and genetic experimentation". Moreover, it was headed by a non-African Indian named Shivaji Poojari and as a result, most of the Siddi issues were left unattended. The organisation was also failing to resist the socio-historical distortion, racial marginalisation and cultural exoticisation of the community in the forms of documentaries and captioned photographs that were curated and archived by government institutions, newspaper reporters, NGOs and tourists from the late 1980s. As a result, the AKSDA was dissolved and was replaced by the Siddi Development Society (from now on SDS).

The SDS was established in 1995 and unlike AKSDA it was headed by a Siddi. At present, the SDS has 12 members and it represents all the Siddis of Karnataka. In order to overcome 'cultural appropriation, racism, assimilation and misinterpretation' (Alloula 2002: 520), the SDS is adopting various practices of "visual sovereignty" which "necessitates an indigenous community's or individual's right to visually create a space for self-definition and determination' (Guffey 2016). In the process of self-defining, the Siddis have framed strict norms and conditions to prevent organisations/individuals to shoot documentaries and capture photographs in their localities without permission. For instance, prior to any kind of video/audio recording and photography, official permission of the SDS is mandatory. A proposal needs to be submitted to SDS which is strictly reviewed by the members, before permission is granted. One of the important parameters of granting permission is that the intentions behind photography and documentary making should be free from any form of social, cultural, historical and racial stereotyping. In other words, instead of racially stereotyping and culturally exoticising them, the visual narratives should make efforts to uphold the habitual existence of the Siddis as realistically as possible. So, in order to ensure it, the documentary film-makers and photographers are always assisted by a Siddi member who functions as a link between them and the Siddi locals. In this manner, they are trying to interrogate and dismantle the existing archives of the visually colonised narratives of Siddi society, history and culture.

To achieve "visual sovereignty", they are also recreating their African socio-cultural practices in the forms of dance, music and food habits and sharing it with tourists, photographers and documentary filmmakers. In addition to SDS, the Siddi Foundation in Gujarat (from now on TSF), which was established in 2017, has developed identical forms of social, cultural and historical initiatives to challenge the "colonial meanings" of the existing visual archives of the Siddis and decolonise it 
(Lydon and Wanhalla 2018: 214). The efforts toward systemic and epistemic decolonisation of the colonially structured archives by the Siddis of Karnataka and Gujarat will be elaborated in the following part of this section.

b A Decolonial Archival Turn: The process of decolonising the colonially structured archive involves a thorough investigation of the "practices of collecting, collating, and classifying photographs' (Lydon and Wanhalla 2018: 213). This is how the Siddis of Karnataka and Gujarat are undergoing decolonial archival turn in the contemporary era. Through reviving and documenting their indigenous Bantu forms of dance, music and food habits, they are providing 'a new perspective on past and present by revealing marginal experiences, asserting indigenous capacity and addressing the losses and fractures of a historical process such as assimilation' (Lydon and Wanhalla 214). For instance, the Siddis of Karnataka perform "call-and-response singing" and Goma music and dance "which can be traced back to the Ngoma style of East Africa' (Asha Stuart quoted in Heather Brady's "How This African Filmmaker" 2018). Figure 7.8 documents a Siddi child from Karnataka who is playing a "Goma" drum, which is almost identical to "Ngoma" drum as used by the Bantus:

The Siddis of Gujarat document their indigenous dance patterns, which imitate the body languages and lifestyles of the 'disappearing species of the Asiatic lions' (United Nations 2017). In the process of

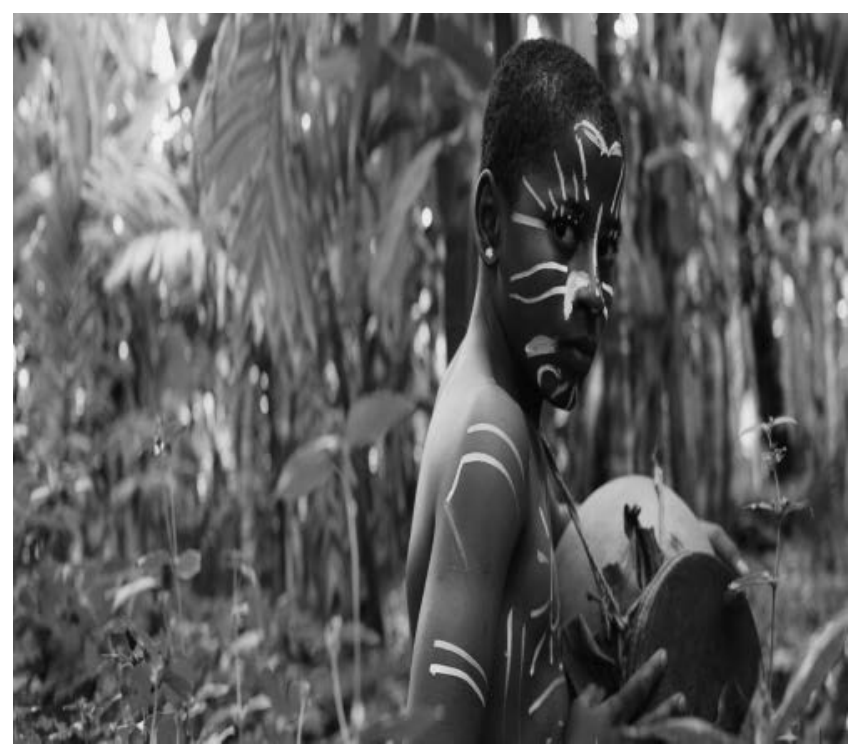

Figure 7.8 Siddi boy with a painted face playing the Ngoma drum. Copyright: Asha Stuart. 
telling the stories of these lions, they dance to the drum beats and patterns that are almost identical to the Bantu people. They not only dance and document these practices among themselves but also share it with tourists, researchers, documentary film-makers and photographers.

Apart from these individual efforts, TSF in Gujarat also organises Siddi music and dance festivals across the year and they are attended by people from different corners of the country. In this way, different aspects of their cultural practices are gaining public attention. Their indigenous cultural practices function as a medium of earning as well. As Imran Siddi reveals: 'We play in hotels for about 1500 rupees or 25 US dollars. We go to the hotel to dance for the tourists during the prime season' (United Nations). This form of dance and music, on the one side, enables them to preserve their indigenous Bantu socio-cultural associations, and on the other side, it allows them to remain disassociated from the economic practices of the mainstream Indian society. Besides music and dance, the documentation and promotion of their food practices is another way through which they are dismantling the colonially structured archives and shaping decolonial socio-cultural archives. The food habits of the Siddis of Karnataka are very close to that of the Bantus. Instead of relying on the artificially packaged protein, vitamin and energy or on the chemically toxic vegetables as found in the city markets, they live on fresh honeycombs, red ant chutney, ${ }^{6}$ mud crabs, fruits and murdis $^{7}$ (101 India 2017).

This is how through collective revival and public exposure of their social, cultural and historical practices the Siddis of Karnataka and Gujarat are systemically and epistemically plundering the visual narrative tools of the colonial masters, disassembling the masters' houses and re-assembling de-hierarchised, de-polarised, de-compartmentalised, de-racialised, decolonised and pluriversalised visual archives of indigenous knowledge, which will neither let the masters' tools nor their houses to exist.

\section{Notes}

1 Imagicides' refers to the killing of the social, cultural, political and racial images of a community through stereotyping and exoticising it in the forms of documentaries, photographs and captions. This process of imagicides in turn leads to 'ontocides' or killing of the nature of being.

2 Here, it is important to note that though caste and communal divisions in India are a precolonial phenomenon, yet the divisions were further widened and politicised during the colonial era (especially at the time of British colonisation) in India. In order to systematise the colonial ethics of 'divide and rule', the colonisers entrusted high office ranks to the Brahmans, Kshatriyas and Vaishyas (all high caste communities), whereas the Sudras (outcastes) and the Muslims were mostly subjects of physical and psychological abuse.

3 A community that is being treated like a museum artifact. 
4 'Dhammam' is a music and dance form which is close to Ngoma style of the Bantu people of East Africa and is practiced by the Siddis in India.

5 The author could not showcase the photos in this book chapter because he was not granted copyrights permission by the newspaper.

6 Chutney originated in India and is referred to a spicy mixture. The red ant chutney is prepared by stone grounding red ants, coconut, onions, garlic, chilies and turmeric.

7 Murdi is a leafy vegetable which is found in the forests of Karnataka and is regularly consumed by the Siddis.

\section{Works cited}

A beautiful Siddi woman 2013, image, Akatasia, 24 June, viewed 30 October 2017, http://akatasia.com/2013/06/24/new-book-a-certain-grace-the-sidi-indians-ofafrican-descent-by-ketaki-sheth/.

African Indian, Siddis of Wada. Karnataka, India2018, YouTube video, added by visualpoet1 [Online]. Available at https://www.youtube.com/watch?v=Gct82p8pfYo [Accessed 8 November 2019].

Albinia, Alice 2012, Empires of the Indus: The story of a river, Hachette, London.

Ali, Omar H. 2011, 'Malik Ambar: The Legacy of an Ethiopian Ruler in India', The Reporter, 20 August, viewed 17 October 2018, https://www.thereporterethiopia. com/Living-and-The-Arts/malik-ambar-the-legacy-of-an-ethiopian-ruler-inindia.html.

Alloula, M. 2002, 'From the colonial harem', in N. Mirzoeff (ed.), The visual culture reader, Routledge, New York, pp. 519-524.

Assman, J. 2008, 'Cultural memory studies', in A. Erll \& A. Nunning (eds.), An international and interdisciplinary handbook, Walter de Gruyter GmBH \& Co., Berlin, pp. 109-118.

Barthes, Roland 1985, The grain of the voice, Hill and Wang, New York.

Bell, J. A. 2008, 'Promiscuous things: Perspectives on the cultural property through photographs in the Purari Delta of Papua New Guinea', International Journal of Cultural Property, vol. 15, pp. 123-139.

Bhat, Prajwal 2019, 'Racing for a better future: The African-origin tribe in K'taka that's turning to sports', The News Minute, 31 March, viewed 11 November 2019, https:/www.thenewsminute.com/article/racing-better-future-african-origintribe-k-taka-s-turning-sports-99255.

Brady, Heather 2018, 'How this African-American filmmaker was inspired by African Indians', National Geographic, 13 April, viewed on 23 November 2019, https://www. nationalgeographic.com/news/2018/04/siddi-people-africa-india-tribe-culture/.

Conklin, Alice L. 1997, A mission to civilize: The Republican idea of empire in France and West Africa, 1895-1930, Stanford University Press, Stanford.

Eeden, Jeanne Van 2004, 'The colonial gaze: Imperialism, myths and south African popular culture', Design Issues, vol. 20, no. 2, pp. 18-33.

Goffman, Erving 1979, Gender advertisements, Harper, New York.

Gordon, Robert J. 1997, Picturing Bushmen: The Denver African expedition of 1925, Ohio University Press, Athens.

Guffey, Darcy 2016, 'Visual sovereignty', Prezi, 9 January, viewed 23 November 2019, https://prezi.com/qz-cjquz3w0c/visual-sovereignty/.

Hardworking Siddi Woman 2019, image, Kamat's Potpourri, 6 June, viewed 5 October 2019, http://www.kamat.com/kalranga/people/afro-indians/11830.htm. 
Harris, Joseph E. 1971, The African presence in Asia: Consequences of the Eastern African slave trade, Northwest University Press, Evanston.

Haviland, Charles 2003, 'Hyderabad's African old guard', $B B C$, 4 August, 21 January 2017, http://news.bbc.co.uk/2/hi/south_asia/3116817.stm.

Hubbard, Sue 1994, Everything begins with the skin, Enitharmon Press, London.

IANS 2013, 'Siddis: little known Indians of East African descent', The Pioneer, 20 September, viewed 28 September 2017, https://www.dailypioneer.com/2013/ india-abroad/siddis-little-known-indians-of-east-african-descent.html.

IANS 2018, 'Discovering little known African tribe', Business Standard, 25 February, viewed 25 February 2018, https://www.business-standard.com/article/newsians/discovering-india-s-little-known-african-tribe-118022500131_1.html.

Indians of African Descent 2016, image, Design Indaba, 22 January, viewed 30 October 2017, https://www.designindaba.com/articles/creative-work/and-whatafrican-diaspora-india.

Indians of African Origin 2019, image, Kamat's Potpourri, 6 June, viewed 5 October 2019, http://www.kamat.com/kalranga/people/siddi.htm.

Jambur: The African village or little Africa in Gujarat2018, YouTube video, added by visualpoet1 [Online]. Available at https://www.youtube.com/watch?v= 1PNzZqQxwjk [Accessed 12 November 2019].

Janardhan, Arun \& Pathak, Maulik 2013, 'Genetics: The race to a better life', Live Mint, 7 September, viewed 1 January 2019, https://www.livemint.com/Leisure/ hFhflj1k0kGRXGr9YAiIGP/Genetics--The-race-to-a-better-life.html.

Keay, John 2011, India: A history, Grove/Atlantic, New York.

Lost Tribe of Africa2018,YouTube video, added by National Geographic [Online]. Available at https://www.youtube.com/watch?v=B_a1WS5ncDk [Accessed 9 November 2019].

Lydon, Jane \& Wanhalla, Angela (eds.) 2018, 'Editorial', History of photography, vol. 42, no. 3, pp. 213-216.

Mabry, Hannah 2014, 'Photography, Colonialism and Racism', International Affairs Review, Fall Issue, pp. 1-7.

Mamdani, Mahmood 2013, 'The Sidi: An Introduction', in Ketaki Sheth (ed.), A certain Grace the Siddi. Indians of African descent, Photoink, New Delhi.

Maturkar, Varun 2017, 'Why Indian Siddis have little hope from this sports scheme for their empowerment', Youth Ki Awaz, viewed on 17 April 2018, https://www. youthkiawaaz.com/2018/05/siddi-tribe-community-special-area-games-racism/.

McLeod, John 2008, 'Marriage and identity among the Siddis of Janjira and Sachin', in J.C. Hawley (ed.), India in Africa, Africa in India: Indian Ocean Cosmopolitanisms, Indiana University Press, Bloomington.

Menon, Amarnath K. 1988, 'Special areas games programme launched to groom sports talent', India Today, 31 May, viewed 21 December 2019, https://www. indiatoday.in/magazine/special-report/story/19880531-special-areas-gamesprogramme-launched-to-groom-sports-talent-797325-1988-05-31.

Mitra, Joydip 2018, 'Pushed to the margins', Fountain Ink, 12 September, viewed 4 August 2019, https://fountainink.in/photostory/pushed-to-the-margins.

Padma, Anisha 2019, 'The multiple pasts and presents of Siddis in India', Sahapedia, 18 July, viewed 20 August 2019, https://www.sahapedia.org/ multiple-pasts-and-presents-siddis-india\#_edn11.

Pandey, Vikas 2014, 'Africans in India: From slaves to reformers and rulers', $B B C, 19$ December, viewed 11 November 2019, https://www.bbc.com/news/ world-asia-india-30391686. 
Pedri-Spade, Celeste 2016, 'Waasaabikizo: Our pictures are good medicine', Decolonization: Indigeneity, Education \& Society, vol. 5, no. 1, pp. 45-70.

Photograph by Asha Stuart 2018, image, National Geographic, 13 April, viewed 11 November 2019, https://blog.nationalgeographic.org/2018/04/13/ explorer-spotlight-asha-stuart-documenting-the-lost-tribes-of-africa/.

Plummer, Lucy 2017, "I met the Siddi people of India and it widened my perception of what it means to be 'Indian'", The Better India, 30 March, viewed 27 December 2018, https://www.thebetterindia.com/93626/india-racism-siddi-african/.

Prashad, Vijay 2002, Everybody was Kung Fu fighting: Afro-Asian connections and the myth of cultural purity, Beacon Press, Boston.

Ramzamma laughs when asked if she is pregnant in 2013, image, The Wall Street Journal, 24 March, viewed 30 October 2017, https://blogs.wsj.com/indiarealtime/ 2013/03/24/uncovering-indias-siddi-community/. Reaktion Books, London.

RSTV Documentary - Siddis of Karnataka2017, YouTube video, added by Rajya Sabha TV [Online]. Available at https://www.youtube.com/watch?v= WqgNnqb7_Z8 [Accessed 8 November 2019].

Ryan, J. R. 1997, Picturing empire: Photography and the visualization of the British Empire.

Segal, Ronald 2002, Islam's black slaves: The other black diaspora, Macmillan, London.

Sekula, Allan 1992, 'The body and the archive', in R. Bolton (ed.), The contest of meaning, MIT Press, Cambridge, 365-391.

Sheth, Ketaki 2013, A certain grace Siddi: Indians of African descent, Photoink, New Delhi.

Siddis of Jamnagar (African Indian or Habshis): The spirituality (2018). YouTube video, added by visualpoet1 [Online]. Available at https://www.youtube.com/ watch? $\mathrm{v}=\mathrm{xH} 7 \mathrm{~d} 3 X 1 \mathrm{piL} 0 \& \mathrm{t}=55 \mathrm{~s}$ [Accessed 18 November 2019].

Siddis: In It For The Long Run 2016, YouTube video, added by 101 India [Online]. Available at https://www.youtube.com/watch?v=ped-uIlw_24\&t=2s [Accessed on 16 January 2018].

Sidi in India 2013, image, Akatasia, 24 June, viewed 30 October 2017, http://akatasia. com/2013/06/24/new-book-a-certain-grace-the-sidi-indians-of-african-descentby-ketaki-sheth/.

The Schomburg Center for Research in Black Culture 2011, 'The African diaspora in the Indian ocean world', The New York Public Library, viewed 12 November 2019, http://exhibitions.nypl.org/africansindianocean/essay-south-asia.php.

The Siddi, an African Community in India2013, YouTube video, added by Nzwamba [Online]. Available at https://www.youtube.com/watch?v=UD7sp-L91Uk [Accessed 26 July 2017].

The Siddis of Karnataka: Part 1 2017, YouTube video, added by 101 India [Online]. Available at https://www.youtube.com/watch?v=Ek4XEWXAD8s\&t=1s [Accessed on 16 January 2018].

The Siddis/Habshis (African Indian) community in TALALA, Gujarat, India (2018). YouTube video, added by visualpoet1 [Online]. Available at https://www.youtube. com/watch?v=M-BAPzaF0SA [Accessed 12 November 2019].

The Siddis: India's Forgotten Tribes2017. YouTube video, added by the United Nations [Online]. Available at https://www.youtube.com/watch? $\mathrm{v}=\mathrm{Q} 4 \mathrm{SNsgwX}$ sys [Accessed 18 November 2019]. 


\title{
8 On the question of decolonisation, gender and political communication
}

\author{
Sally Osei-Appiah
}

\section{Introduction}

In June 2019, the President of Ghana, Nana Addo Dankwah Akufo-Addo, came under much public criticism for his comments at a Women Deliver conference in Canada where he is reported to have said:

What I've seen in the two and a half years that I've been in office, that not enough movement is being made by the $52 \%$ of the Ghanaian population that are women to be able to be in a position to make decisions... we're not seeing enough dynamism and activism on the part of those we're seeking this new...I'm talking about dynamism where it mattered. Dynamism is not sitting around here and talking. I'm talking about electing people to parliament, controlling political parties because they're the instrument by which our societies make decisions. We're talking about decisions, not wishes and hopes.

Understandably, the most criticism came from Ghanaian women's groups and various civil society organisations, who felt that his disparaging comments disregarded their many years of political action resulting is endless frustrations and disappointments. In the aftermath, government spokespersons including women parliamentarians lined up to defend the president, but the damage had already been done. His comments at such a conference were not only ill-advised but also demonstrated his lack of appreciation of the structural barriers that impeded women in African societies. The idea that women's failure to gain leadership in politics is an individual responsibility rather than the result of historical, systemic barriers is not only disingenuous but also insidious. It presents a structural, societal problem as an individual issue, thereby removing attention from those who work to sustain that order, or who have the power to effect the necessary change. It also disregards the legacy of colonial rule which has contributed in the most part to the subjugated, lived experiences of many women in African societies. When women's issues are presented as micro rather than macro problems, it pushes them to the periphery of social consciousness which 
in turn diminishes their importance not just in politics but also in political communication. Decolonising political communication ensues that gender issues and concerns are revalourised in the subfield. It entails deconstructing our understandings of gender and women's lived experiences, including their struggles in society, to recognise the multiple intersecting layers of oppression they face largely as a consequence of colonial legacy, and how that has shaped their present status in society. As the co-editors note in the introduction, it is about raising consciousness around gender issues and contextualising them in political communication research. This will give space in the scholarship to the correct explication of the impediments that confront women in African societies and their impact thereof in relation to women's interaction with and communication about politics.

According to Tamale (2020:3), 'gender is a blind spot in mainstream decolonial scholarship on Africa' and the same is true for political communication research. In many countries in Africa, women form the majority. World Bank (2019) figures show that 33 out of 57 African countries have a majority female population. Yet, gender research in political communication research is very limited (Sandberg and Ohberg, 2017). There is a decidedly male normativity in political communication scholarship although it has been long established that women's experiences are not the same as men (Ross, 2017; Steeves and Awino, 2015). Women in African societies experience multiple, intersecting layers of oppression (Afisi, 2010; Ebulonuwa, 2009; Tamale, 2020), which are absent from the experiences of men. As Steeves and Awino (2015:86) assert, 'African women have experienced immense economic, political and ideological oppression'. The disproportionate impact on their lived experiences causes many disadvantages that are absent from the lives of men, and these also shape their political experiences.

Even within women's issues, contextualisation needs to occur to account for the differentiated experiences of women based on colonisation. The colonial history that women in the continent grapple with has so shaped their lives as to distinguish them from women in other Western and other contexts (Amadiume, 1987; Bosch, 2011; Ebunoluwa, 2009). Thus, in this decolonisation enterprise, gender also needs to be disentangled from race (Tamale, 2020). Much as women's experiences differ from men, so are African women's lived experiences dissimilar in many ways compared to their Western peers. In resisting Western hegemony in political communication, therefore, we must also resist a homogenisation of women's experiences.

Given the prevailing situation as described above, this chapter sets forth two key arguments. First, in order to decolonise political communication, it is necessary to decentre androcentrism in the scholarship by reclaiming an equal and complimentary not hierarchical space for women. Afisi (2010) rightly points out that in pre-colonial African societies, there was no gender inequality as each gender and their contribution to the community were regarded as important. Women occupied an equal and complimentary position to men in these traditional communities. St. Clair (1994:27) also 
notes that instead of patriarchy, there was a 'co-dependence and a balance that existed' among women and men prior to colonisation. Decolonising political communication therefore means bringing women back from the obscurity of the margins into the centre in a way that reflects their status in pre-colonial African societies. Second, decolonising political communication involves making explicit the contextual realities which distinguish African women's lived experiences from those in Western and other contexts. Centring the context within which African women are located ensues that the necessary nuance is achieved in the scholarship. In setting forth these two key arguments, the chapter focuses on Ghanaian and Nigerian women politicians, using their experiences to highlight some of the enduring effects of colonisation as well as gender norms which still shape how women politicians are perceived and evaluated, and which, in turn, affect their communication strategies. The chapter draws on 49 semi-structured interviews of women and men politicians, civil society experts and news workers in Ghana and Nigeria, all of which were conducted between October and November 2017.

\section{Decentring androcentrism in political communication}

Historically, politics has been regarded as a male preserve (AdeniyiOgunyankin, 2014; Sossou, 2013). This idea is so entrenched that women politicians are persistently framed as outsiders. It is no surprise, therefore, that male dominance in politics was a key theme that soon became apparent in the interviews. A female civil society expert in Nigeria notes:

When you think politics in Nigeria, you think male. (For) most people, if they think public office in Nigeria, they think male so even that orientation, that mindset is already a very big problem.

While the comment relates directly to Nigeria, Ghanaian interviewees observed the same as is likely the case in many other African countries. Male dominance in politics is also reflected in political communication research (see e.g. Agunbiade and Akiode, 2017; Ette, 2017; Maractho, 2018) where women are decentred and their representation is largely absent. However, as voters and politicians, the issues, concerns and struggles of women differ significantly from men. Culture ensues it while the media largely perpetuate it. To continue in this trend is to sustain patriarchal culture which has conditioned all aspects of life in African societies (Ndlovu and Mutale, 2013). Much evidence suggests that before colonial rule, African women enjoyed immense political, social and economic status (Chuku, 2018). This changed with the arrival of colonisation when the indigenous institutions which guaranteed women's authority and influence were replaced with a masculinised colonial administration that diminished women's power and social status (ibid; Adeniyi-Ogunyankin, 2014; Afisi, 2010). Callaway 
(1987:51), for instance, writes that the colonisers 'assumed African women generally to be in a dependent and subordinate position to men even in areas where women were noted for their independent trading activities and their political power'. In line with their Victorian values, they established a hierarchical gendered tradition characterised by gender roles in which women were assigned the subordinate and limiting private sphere of domesticity, while men occupied the more authoritative and politically engaging public sphere. Women were subsequently rendered less important and made invisible in the colonial rule that ensued (Adeniyi-Ogunyankin, 2014; Chuku, 2018; St. Clair, 1994).

The ideals of colonisation once established, endured as a legacy, firmly entrenched in the cultural gender expectations that define acceptable behaviour from women and men in most African societies. The result of such a colonial enterprise was the confinement of women to domestic life. At the time, the primary expectation of women was that of marriage, childbearing and caregiving, all of which were regarded as roles to be aspired for (Imafidon, 2013). If women were only expected to marry, give birth and take care of their households, then there was no need to invest in their education, train them professionally or build their leadership capabilities. Men, however, because they were viewed as natural leaders, were socialised and equipped to fulfil their role as decision-makers. They were seen as more politically competent and successful. Likewise, women who fulfilled their gender-defined roles as pertaining to the family were viewed as "responsible" while those seeking political office were viewed as challenging God's order, opening themselves up for stigmatisation, harassment and disapproval from family, friends and even other women (Adeniyi-Ogunyankin, 2014). As will be shown below, these gendered expectations associated with politics are also evident in the way women politicians are generally framed in media content. In the same way that the universalisation of Western ideology is no longer tenable, so it is unacceptable to continue with the androcentric focus in political communication scholarship when it only presents a limited understanding of political communication processes.

Another key institution that helps perpetuate women's subordinate status in society is culture. To illustrate its defining influence on women politicians, here is an explanation from one of the Ghanaian female politicians:

When we go to villages and have to pay homage to the chiefs, the chiefs will be sitting and as the candidate, I am probably there with the executives of that constituency so hierarchically I am higher. We walk into these chiefs' palace and they say to me "women don't go there". Traditionally, women shouldn't go there, or the men should go ahead of you to greet. You don't go ahead first. So, the men sit down. They are sitting in front and I am sitting at the back, and yet, I am going to address these chiefs. It is ridiculous. But this is culture or socialization or tradition. 
Apart from such traditional practices which ensure women's subordination to men, there are also proverbs which serve to rob women of their voice as explained by this male journalist:

I think Ghanaian female politicians are not as bold as you would expect of politicians seeking to lead the people. That has its own deep roots in the kind of values that we hold in a society like Ghana, the fact that (culturally, we say) "ok men are talking; you women must keep quiet". These are things that happen within a cultural setting, and they go a long way either directly or indirectly to influence how female politicians carry themselves.

Traditionally, women are expected to defer to men as husbands and leaders of the community. There is a popular Akan adage, for example, that states that women must only be seen and not heard. Yet, to be successful in politics, politicians are expected to not only be vocal but also articulate in communicating their views and policies. Thus, for women politicians, the deliberate cultural effort to deprive women of their power of expression is especially damaging as it goes contrary to the very nature of politics. These contradictions therefore present quite a dilemma for women politicians, particularly as the media grows increasingly influential in politics (Strömbäck and Esser, 2014). To conform to gender expectations is to set themselves up for obscurity and a potential end to their political careers. To resist it risks setting themselves up for public abuse. These are the sorts of challenges which women politicians continually tackle but which are absent for male politicians. They highlight the gendered disparities apparent in African cultures, which subsequently also affects how women politicians communicate. Challenges such as these do not just relate to voice but also to legitimacy. Being allowed to speak confers legitimacy, authority and importance (O'Neill et al., 2016; Wagner et al., 2017). The fact that women politicians are denied these culturally is evidence of the inequalities that persist, which also must be reflected in political communication research. Given these gendered differences, women can no longer be ignored as this female civil society expert in Ghana asserts:

Women cannot be disregarded. First of all, they present a different perspective. They have different needs; they have different concerns and those concerns and needs and cannot be represented by people who don't have or experience them.

As noted, women bring different perspectives that can only enrich political communication research. A deliberate effort to centre women's issues in the research agenda will not only facilitate better and more comprehensive theorising in the subfield, but also open new areas of enquiry to enable better understanding of phenomenon that confront scholars in their research. 


\section{Contextualising gender in political communication research}

Salgado (2019) makes a strong case on the need to contextualise research in political communication in order to avoid what Sartori (1970) calls "conceptual stretching". One area that can benefit much from contextualisation is research on women. In many ways, African women's experiences differ from Western women. For one thing, Western women do not have to deal with the taxing baggage of colonisation. Further, the concept of womanhood in African societies is inscribed in cultural values which espouse a high level of awareness of and responsibility to family and community as well as adherence to high social etiquette, all of which signify female beauty (Chuku, 2018; Imafidon, 2013). This contrasts with Western feminist ideals of independence (Imafidon, 2013). Steady (2007:154) for instance notes that 'the study of women and gender in Africa in the $21^{\text {st }}$ century cannot escape the realities of post-colonial hegemonic domination of Africa by Europe and North America'. This suggests that the way womanhood is conceptualised in Africa carries cultural resonances that are absent in expectations of Western women. It is important to acknowledge this in political communication research which focuses on gender. Tamale (2018:45) also argues that 'the oppression of African women intersects with other forms of structural oppression (based on race, ethnicity, class, religion, disability, sexual orientation, etc.) to compound their injustices'. Women in African societies do not only have to tackle gender biases but also resist the homogenisation of their lived experiences. This implies that even within the category gender, distinction needs to be made between various other layers of discrimination such as race because gender, after all, is both a historical and cultural phenomenon (Oyewumi, 2005). The way African women - as voters and as politicians - experience, relate to and communicate politics are coloured with the residue of the cultural infrastructures established during colonial rule. In contextualising gender research in political communication, we can begin to unpack the various context-dependent factors which culminate in shaping African women's experiences in quite distinct ways. In particular, we can consider the effects of incentive-driven coverage by African media and social media on women politicians' communication.

As a constitutive part of the triad of political communication (besides political actors and citizens), the media play a crucial role in contemporary politics. Increasingly, the media have become 'a dominant space in politics today' (Dahlgren, 2000:313), leading to a highly mediatised political terrain (O’Neill et al., 2016). It is safe to say that in many countries, including those in Africa, the media are the "primary source of symbolic material out of which people construct their understanding and evaluation of political actors, conditions and events' (Dan and Iorgoveanu, 2013:1028). Yet, as with culture, the media are not neutral but very gendered in their coverage of political news and actors (Anderson et al., 2011; Ette, 2017; O'Neill et al., 2016; Ross, 2017). There is overwhelming evidence that points to biased media 
coverage which favours male politicians in terms of giving them voice, more space, greater range of topics to speak on and an essentially issue-based coverage, while female politicians have to contend with erosion of their presence and voice, marginalisation, infantilisation as well as trivialisation of their political contributions(Ette, 2017; Ibroscheva and Raicheva-Stover, 2009; Osei-Appiah, 2019; Ross, 2017). For example, Katembo (2005) shows that during the 2004 South African general election, only 26 women politicians were used as news sources in the Sunday Times compared to 313 male politicians. Anderson et al. (2011) also reveal that coverage of Ellen Johnson Sirleaf in both local and international newspapers highlighted her physical appearance, maternal and marital status while her male political opponent, George Weah, was spared the sexist coverage. These examples highlight the media's complicity in perpetuating both the erasure and trivialisation of women's political contribution which also affects how they are perceived and evaluated by voters. In so doing, the media serve to sustain the colonial enterprise of male dominance in politics as such practices not only contribute to less favourable evaluations of female candidates but also discourage women politicians from engaging with the media (Ette, 2017; Osei-appiah, 2019; Ross, 2017).

One of the ways biased coverage manifests itself is through incentivedriven reporting whereby event organisers including political actors pay media houses to cover their events. Payment can be in the form of cash or in kind. The practice is quite endemic among media organisations in most of Africa (Amankwah et al., 2017; Osei-Appiah, 2019; Sampaio-Dias, 2019; Skjerdal, 2018). The challenge with incentive-driven coverage is that it creates a media culture that undermines the ideals of journalism in that it facilitates biased reporting while constraining diversity in media content (Sampaio-Dias, 2019). In particular, it is exclusionary as it prevents many women politicians from being seen and heard in the media space because they are unable to pay for coverage (Osei-Appiah, 2019). In the interviews, there was unanimous consensus among women politicians that their biggest challenge is finance. Yet, political advertising was one of the most expensive. There were many who said they were either absent or had very limited media visibility due to their inability to pay. Here is what a Nigerian female politician had to say:

For traditional media, you have to be either invited or pay. I had a few invitations like that, but I was not able to advertise because what happens in Nigeria is that for the media, the jackpot is their advertorial prices during elections. They say this is the time they can make a lot of money so that $30-40$ seconds on television will cost you like almost a millionaire naira.

Limited media coverage implies few opportunities to make themselves visible as candidates, to communicate their policies and issue positions, and to 
contribute to political debates. This ultimately affects the quality of political information presented to citizens as it only reflects a partial view of the political reality in that context (Osei-Appiah, 2019). Despite its pervasiveness in African journalism, research has shown that incentive-driven coverage is a phenomenon that is not common in Western contexts (Mabweazara, 2018). This means one less commonality between women in Africa and those in the West.

Another key context-dependent factor which distinguishes African women's experiences from those in the West is social media and the extent to which they are embedded in political communication strategies in the continent. Some scholars have heralded social media for their equalising ability to increase access for both elite and marginalised groups (Boulianne, 2015; Diamond, 2010). Such optimism, however, does not take into account prevailing realities in non-Western contexts such as in Africa where, among others, internet costs are not only prohibitively expensive but also quite unstable in many areas (Dwyer and Molony, 2018). In fact, sub-Saharan Africa has one of the lowest rates of internet penetration in the world, showing a penetration rate of $32 \%$ which is well below the world average of $42 \%$ (Dzisah, 2018). It must be noted, however, that due to the rapid expansion of mobile telephony and the rate of internet penetration in the continent, future projections are very optimistic. Nonetheless, we also need to acknowledge that social media use is not the norm in Africa (Nyabola, 2018) as it is in the West. In fact, there are gendered disparities in social media access which Dwyer and Molony (2018:3) argue 'often overlap with broader issues of socio-economic gender inequalities'. Difficulties with erratic power supply and high levels of illiteracy in many parts of Africa also influence politicians' perceptions about social media's value to their political goals. For example, some women politicians believed that social media was more for educated people than illiterates which suggested that those who represented rural communities found less need for their use. The following quote by one of the Ghanaian women politicians illustrates this point:

In the village, you don't always have Internet so if you're in a rural constituency, social media may work with the students but they're still a minority...those thousands of women who, as a woman, are your natural supporters, they will support you, but they will not check social media. You have to use the simplest form of media you can use to get to them.

Others also noted difficulties with maintaining internet connectivity during campaign road trips as well as lack of technical knowhow regarding how the platforms operate. Another Ghanaian women politician described her experience:

I'm learning it as well. It's a new thing for me and I need to just learn it. I'm fast now. I don't even know how to get to Twitter but I had a young lady here and I'd tell her what I want and she would do it on Twitter. 
It must be noted, however, that while these views were quite dominant in the interviews, there were also women politicians who used social media extensively in their campaigns. The divergent views represented in the interviews suggested that there were mediating factors which affected women politicians' use motives. These generally related to the demographics of constituency members, age and technical literacy of the politician as well as political function. Women politicians who did not know how social media sites operate, who contested at the local level or whose constituencies were located in rural areas generally used social media less if at all, while those representing urban areas, contesting for national positions or having greater financial freedom, were more likely to regularly use social media. Some of these factors, particularly those relating to connectivity challenges, high cost of data and illiteracy, are issues which demonstrate differences in contexts for African women and those in the West.

\section{Conclusion}

In this chapter, I have proposed two ways that political communication can be decolonised in relation to gender. I have argued for a refocus in political communication research which entails decentring its androcentric predominance and recentring gender-sensitive research in ways that accord complimentary importance to women's issues. Just as it is necessary to destabilise the Western dominance in the subfield, so it is that our present appetite as African scholars should make it equally intolerable to maintain the current male dominance in the scholarship. This is not to suggest a "take over" of women's issues in the subfield. It is simply to point out that not doing this risks producing knowledge that only provides a limited view of the range of topics, issues and concerns in the political realities that engage us as scholars of political communication. Inclusion and diversity have recently become trendy terms which can be usefully appropriated in this context. Recentring gender in political communication will ensure greater diversity in the scope of research while also guaranteeing fair representation.

Beyond recentring gender, I have also argued for contextualisation in gender research to allow for greater nuance in research findings. The impact of context in shaping political processes and practices needs no emphasis as it is quite evident (Salgado, 2019). Therefore, it is necessary that we resist the homogenisation of women's experiences in the subfield by emphasising context in gender research. This will eliminate the risk of overlooking important causative elements which shape the phenomenon we study while also facilitating a better understanding of the complexities that context often presents in empirical research. Decolonising political communication should therefore entail an explicit reference to the influence of context within the boundaries of gender-sensitive research. Following these two proposals as outlined above will inevitably lead to richer, more equitable and more diverse scholarship which will ultimately facilitate better theorising in the subfield. 


\section{References}

Adeniyi-Ogunyankin, G. 2014. "Spare Tires," "Second Fiddle," and "Prostitutes"? Nokoko. 4, p. 11.

Afisi, O.T. 2010. Power and Womanhood in Africa: An Introductory Evaluation. The Journal of Pan-African Studies. 3(6), pp. 229-238.

Agunbiade, T. and Akiode, O. 2017 Gender and Political Communication in Africa. In: A. Olukotun and S. Omotoso, eds. Political Communication in Africa. Springer, Cham. https://doi.org/10.1007/978-3-319-48631-4_10

Akufo-Addo, N.A. 2019. Speech at Women Deliver Conference. Accessed 12 December 2020. Retrieved from Joy News - President Nana Akufo-Addo at the much talked about Women Deliver Conference 2019 in Vancouver, Canada \#JoyNews - Bing video

Amadiume, I. 1987. Male Daughters, Female Husbands: Gender and Sex in an African Society. Basingstoke: Palgrave Macmillan.

Amankwah, A.S., Ako-Gyima, E. and Quansah, J. 2017. The 'Brown Envelop' and Media Practice in Ghana: A Socio-cultural Perspective. Journal of Communication, Media and Society. 4(1), pp. 43-61.

Anderson, J.A., Diabah, G. and Mensah, P.A. 2011. Powerful Women in Powerless Language: Media Misrepresentation of African Women in Politics (the Case of Liberia). Journal of Pragmatics. 43(10), pp. 2509-2518.

Bosch, T. 2011. African Feminist Media Studies: A View from the Global South. Feminist Media Studies. 11(01), pp. 27-33.

Boulianne, S. 2015. Social Media Use and Participation: A Meta-Analysis of Current Research. Information, Communication and Society. 18(5), pp. 524-538.

Callaway, H. 1987. Gender, Culture and Empire: European Women in Colonial Nigeria. London: Palgrave Macmillan.

Chuku, G. 2018. Colonialism and African Womanhood. In S. Martin and F. Toyin, eds. The Palgrave Handbook of African Colonial and Postcolonial History (pp. 171-211). New York: Palgrave Macmillan.

Dahlgren, P. 2000. Media, Citizenship and Civic Culture. In: J. Curran and M. Gurevitch, eds. Mass Media and Society (pp. 310-328). London: Edward Arnold.

Dan, V. and Iorgoveanu, A. 2013. Still on the Beaten Path: How Gender Impacted the Coverage of Male and Female Romanian Candidates for European Office. The International Journal of Press/Politics. 18 (2), pp. 208-233.

Diamond, L. 2010. Liberation Technology. Journal of Democracy. 21(3), pp. 69-83.

Dwyer, M. and Molony, T. 2019. Social Media and Politics in Africa. London: Zed Books.

Dzisah, W.S. 2018. Social Media and Elections in Ghana: Enhancing Democratic Participation. African Journalism Studies. 39(1), pp. 27-47.

Ebunoluwa, S.M. 2009. Feminism: The Quest for an African Variant. The Journal of Pan African Studies. 3(1), pp. 227-234.

Ette, M. 2017. Where are the Women? Evaluating Visibility of Nigerian Female Politicians in News Media Space. Gender, Place \& Culture. 24(10), pp. 1480-1497.

Ibroscheva, E. and Raicheva-Stover, M. 2009. Engendering Transition: Portrayals of Female Politicians in the Bulgarian Press. The Howard Journal of Communications. 20(2), pp. 111-128.

Imafidon, E. 2013. 'Miss Independent': Gender and Independence on the African Continent. Inkanyiso: Journal of Humanities and Social Sciences. 5(1), pp. 21-30. 
Katembo, T.K. 2005. The Representation of South African Women Politicians in the Sunday Times During the 2004 Presidential and General Elections. Unpublished MA dissertation. Accessed 10 December 2020. Retrieved from: https:// core.ac.uk/download/pdf/49241569.pdf

Mabweazara, H. 2018. Reinvigorating 'Age-Old Questions': African Journalism Cultures and the Falacy of Global Normative In: H. Mabweazara, ed. Newsmaking Cultures in Africa-Normative Trends in the Dynamics of Socio-Political \& Economic Struggles (pp. 1-29). Basingstoke: Palgrave Macmillan.

Maractho, E.C. 2018. Determinants of Participation in Political Communication in Uganda's Broadcast Media: Implications for Women. In B. Mutsvairo and B. Karam, eds. Perspectives on Political Communication in Africa (pp. 79-94). Cham: Palgrave Macmillan.

Nyabola, N. 2018. Digital Democracy, Analogue Politics: How the Internet is Transforming Kenya. London: Zed books.

Ndlovu, S. and Mutale, S.B. 2013. Emerging Trends in Women's Participation in Politics in Africa. American International Journal of Contemporary Research. 3, pp. 72-79.

O’Neill, D., Savigny, H. and Cann, V. 2016. Women Politicians in the UK Press: Not Seen and Not Heard? Feminist Media Studies. 16(2), pp. 293-307.

Osei-Appiah, S. 2019. News Media Logic and Democracy: Strange Bedfellows in Political News-Making Practices of Private Radio Stations in Ghana. African Journalism Studies. 40(3), pp. 57-72.

Oyewumi, O. 2005. Visualizing the Body: Western Theories and African Subjects. In African Gender Studies A Reader (pp. 3-21). New York: Palgrave Macmillan.

Ross, K. 2017. Gender, Politics, News: A Game of Three Sides. Oxford: Wiley-Blackwell.

Salgado, S. 2019. Never Say Never ... Or the Value of Context in Political Communication Research. Political Communication. 36(4), pp. 671-675.

Sampaio-Dias, S. 2019. Per Diem Payments as a Form of Censorship and Control: The Case of Guinea-Bissau's Journalism. Journalism Studies. 20(16), pp. 2349-2365.

Sandberg, L.A.C. and Öhberg, P. 2017. The Role of Gender in Online Campaigning: Swedish Candidates' Motives and Use of Social Media During the European Election 2014. Journal of Information Technology \& Politics. 14(4), pp. 314-333.

Sartori, G. 1970. Concept Misformation in Comparative Politics. The American Political Science Review. 64(4), pp. 1033-1053. doi:10.2307/1958356

Skjerdal, T. 2018. Brown Envelope Journalism: The Contradiction Between Ethical Mindset and Unethical Practice In: H.M. Mabweazara, ed. Newsmaking Cultures in Africa - Normative Trends in the Dynamics of Socio-Political \& Economic Struggles (pp. 163-185). Basingstoke: Palgrave Macmillan.

Sossou, M.-A. 2011. We Do Not Enjoy Equal Political Rights. SAGE Open. 1(1). doi:10.1177/2158244011410715.

St. Clair, William. 1994. Imperialism and Traditional African Culture. Cambridge: Cambridge University Press.

Steady, F. 2007. African Women: Re-Centering the Issues for the 21st century In: A. Mazama, ed. Africa in the 21st Century: Toward a New Future (pp. 133-154). London: Routledge.

Steeves, H.L. and Awino, I. 2015. Gender divides and African journalism practice. African Journalism Studies. 36(1), pp. 84-92. 
Strömbäck, J. and Esser, F. 2014. Mediatization of Politics: Towards a Theoretical framework In: F. Esser and J. Strömbäck, eds. Mediatization of Politics Understanding the Transformation of Western Democracies (pp. 3-28). London: Palgrave Macmillan.

Tamale, S. 2020. Decolonization and Afro-Feminism. Ottawa: Daraja Press.

Wagner, A., Trimble, L., Sampert, S. and Gerrits, B. 2017. Gender, Competitiveness, and Candidate Visibility in Newspaper Coverage of Canadian Party Leadership Contests. The International Journal of Press/Politics. 22(4), pp. 471-489. 


\section{Part III}

Music, radio, and social media as politicised "spaces" 

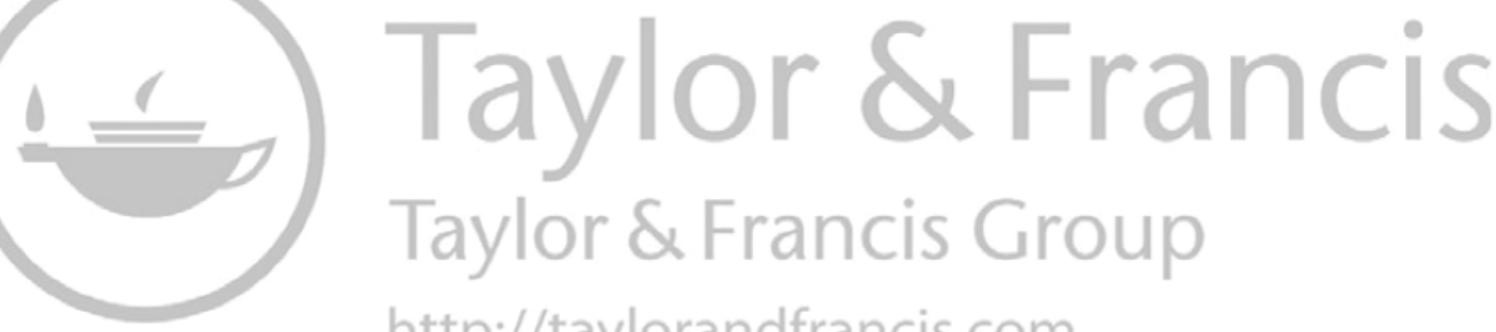

http://taylorandfrancis.com 


\title{
9 Freedom in the jazz imaginary Twentieth-century aesthetic revolt
}

\author{
Salim Washington
}

\section{Introduction}

Since its inception, this music developed as an antidote to colonial domination. It not only serves as a potent resistance to the colonial condition, but also functions as an epistemological framework capable of providing answers to its fruits, many of which survive de jure colonial structures. The decolonizing efficacy of the music resides in its theoretical underpinnings as well as in its various practices. The proposed chapter is a theoretical intervention rather than a case study per se. I argue that the jazz imaginary is a Pan-African invention, its most relevant origins and reinventions occurring in the contexts of spectacular displays of unfreedom, whether in slavery, settler colonialism, or systematic race-based discrimination. The music fashions its own presentation of freedom over time, formally increasing degrees of latitude with respect to musical features such as rhythm, timbre, and melodic/harmonic development. The jazz imaginary, too, has developed to help shape the reception, critical commentary, and ultimately the aesthetic and social meanings of jazz in such a way as to give credence to (or in some instances to deny) the revolutionary import of jazz music and culture. My analysis will utilize the insights and methods of ethnomusicology, Africana studies, literary theory, and the burgeoning field of Black Atlantic studies.

I argue that the origins of black modernity for African Americans, which culminate in various jazz traditions, begin with the Atlantic slave trade for African Americans. The dreaded Middle Passage, and the conditions with respect to racial versus ethnic identity in the United States presented the conditions for Pan-African consciousness in a way that did not necessarily obtain in what we now think of as Africa. The music is marked since its beginning by a longing for literal freedom. The music begins its modernist trajectory both borrowing from and utilizing Western musical instruments and ideas, while at the same time extending, and at times critiquing and even subverting these same traditions from the position of the subaltern to meet their (evolving) cultural needs.

The musical history considered would include the introduction of AfroChristianity that emerged after the Great Awakening and result in the 
musical matrix and training ground for many of the musicians who would "invent" and develop early jazz, with examples from the music of the South Sea islands off the southeastern coast of the United States, demonstrating the early compromises between tonal and rhythmic practices that were developed from Europe and Africa. Later would come the introduction of blues and then the urban blues, in the states, Marabi and then mbaqanga in South Africa. In both countries the music's artistic development is related to the changing position of blacks within the political economy. Later still, and with markedly expanded musical parameters, would come the mid-twentieth century, self-consciously modernist music. Examples would include Charles Parker and Bud Powell in the United States and figures such as Kippie Moeketsi and Barney Rachabane in South Africa. Even in this revolt there is a care to master the diatonic forms in much the same way as the strategy of civil disobedience appealed to the higher conscience of their erstwhile oppressors. This trajectory continued during the modal explorations of Winston Ngozi, Wayne Shorter, Philip Thabane, and the later more-revolutionary assault upon the diatonic system by the likes of Albert Ayler, Mongezi Feza, and Dudu Pukwana.

In each of these examples, there is a positive correlation between time periods and the greater liberties and license represented in the melodies, rhythms, and timbres of the music. Further, in each historical moment the changes in the parameters of the music are accompanied by significant social movements among the people, and also the jazz imaginary as represented through literature, commentary, dance, visual arts, and especially poetry which all developed in tandem.

This trajectory, though discernible, is certainly not entirely linear. This is particularly evident in the music of post-Black Power days in both countries. However, the perceived need to seek further freedom in certain musical parameters remains a significant part of both contemporary jazz and its attendant imaginary, if in a decidedly post-modern fashion. Examples could include, for instance, Zim Ngqwana, Andile Yenana, and most recently Mandla Mlangeni in South Africa, and the Art Ensemble of Chicago, Matthew Shipp, and hip-hop star Kendrick Lamar in the United States.

In an interview published as "Sonny Rollins on Jazz as a Music of Freedom" the "Saxophone Colossus" recalls meeting and performing with Sun Ra toward the beginning of his career in Chicago in the 1940s when he was still known as Sonny Blount. Ra, one of the most philosophical jazz musicians in the history of the music, made a statement that stuck with Rollins even after six decades: "Jazz, in all stages of its development, had to do with freedom. Otherwise it wouldn't be jazz." Sonny Rollins is himself speaking publicly quite often in an explicit philosophical mode. Perhaps, in terms of collaborations with the architects of the tradition and historic recordings, Sonny Rollins is perhaps the greatest living jazz musician. The only peer in 
these respects may be Roy Haynes. Unlike Haynes, Rollins can no longer perform due to health issues. He has donated his papers and has become quite vocal about his experiences and thoughts about the meaning of the music. Commenting on Sun Ra's comments about jazz and freedom, Rollins goes on to consider the mechanics of jazz practice, especially in relation to other black music traditions: "Jazz always seeks to break down barriers; there is also a fight, a struggle, the need to make a breakthrough, to create anew." 2

The twentieth century was witness to stylistic renderings through music of one of the greatly protracted struggles against social and political unfreedom through the aesthetic revolt that is jazz music. The published record of the music via commercial and amateur recordings shows that Amiri Baraka was right - the music can be heard as a repository of the history and aspirations of African American people. As the historic political and social victories of black people over time fashioned increasing degrees of self-determination including milestones such as emancipation from slavery, evading the peonage of the share cropping system, and dismantling the legal basis of Jim Crow practices, so too did the degrees of freedom evident in the musical features and processes of music-making show increasing degrees of openness and inventiveness. Nowhere is this more dramatically revealed than in the history of jazz. The ever-increasing lack of restrictions was expressed through an expansion in the choice of instruments, the use of the body, the strictures of melody making, the conventions of harmony and forms, the timbres used, as well as the philosophical notion of what constitutes a beautiful sound. As much as the musical features expanded in possibility there was also a decided progression away from the hegemony of Western musical thought and practices toward the fashioning of what came to be understood as a black aesthetic. The innovations that characterise the music are not simply formal experiments, but also represent the yearnings and advancements of a people inasmuch as the technical innovations have social and political valences.

This history of blackness, this tradition of jazz for instance, as a constituent of, and commentary on Western modernity is in Fred Moten's words where essence and performance meet. 'Blackness is ... a special site and resources for a task of articulation where immanence is structured by an irreducibly improvisatory exteriority that can occasion something very much like sadness and something very much like devilish enjoyment'. ${ }^{3}$ An aesthetic tradition that is born of a social history of oppression and exploitation does have traceable elements that can seem like anguish, sadness, and so forth. But to only see that side of the equation is one of the more common if most profound misreading of the blues in particular and black culture in general. The radical trajectory toward freedom in jazz is built as much upon the vision and hopefulness of the African American people as it is on the degree to which the people have grown in the context of unfreedom. 
Rather than use their creative energy toward nihilism, African Americans fashioned a freedom of the imaginary that foretells the world as they would have it.

The essential nature of African American music was established by the needs that it fulfilled, including conditions that predate the starting point of the music that would come to be called jazz. The beginnings of African American music are on the ships of the dreaded Middle Passage. It was a traumatic beginning of a people and its culture. Being not only captives but chattel, not only property but officially demonised out of full humanity, African American culture by necessity was created expressing the need for freedom and for a more expanded sense of humanity for all. In a situation in which those on the ship had come from diverse cultures and language groups, in a way Pan-African reality was immediately a part of African American culture. The ethnic ways of being would over time evolve into a racial identity, foisted upon blacks through ideologies (sanctioned by the European intelligentsia) and social practices (sanctioned by the European governments and those of their colonies). Slavers would bring African instruments on board and force the captives to sing and dance as an antidote to the sickness and death that the living conditions engendered. So, African American music is since its inception both Pan-African in nature and quite literally utilised for the psychic and ontological survival of the people.

One of the earliest innovations in jazz and in African American music in general is the musical instrument known as the drum kit. Perhaps, its origins can be traced in a way to the Stono Rebellion of 1739 in the colony of South Carolina. In the aftermath of the rebellion was the enactment of the Black Codes which prohibited the practice of African religion and the playing of African instruments, especially drums. Without the continuation of specific religious institutions and musical forms and instruments, such as occurred throughout much of the so-called New World, such as in Cuba, Brazil, and other countries, African Americans were forced to invent new forms and practices to incorporate their need for African expressions and epistemologies, as well as to express their Americanness, such as it was.

The voice was (and remains) the primary musical instrument of African Americans. The spirituals and other songs utilised in sacred and secular situations formed the musical foundation of United Statesian music. When the leading scholar of what we now call the American Renaissance, Ralph Waldo Emerson, made his famous call for the American scholar, he played a part in what has been an enduring American tragedy. He wanted the United States to cease being a second-rate Europe in culture and intellectual pursuits and to develop its native genius on its own terms. The irony, of course, is that this was already happening as he spoke, but the right audience was not at Harvard where he was delivering his impassioned address. It was occurring on the plantations among the slaves. This subaltern voice was already artistically proclaiming the truth about America in insightful and original terms (Emerson 1837). 
It may seem odd to focus on the antebellum period or slavery in general when discussing the contours of jazz music. It must be remembered, however, that the period of slavery was roughly twice as long as the period post-slavery, and thus an all-important incubator of African American culture, be it music, religion, political struggle, family structure, and so on. There also appears to be a correlation between the degree of unfreedom and the consequent expansion of freedom expressed musically. While the most original and important music from the country during slavery was the spirituals, the 1890 s almost miraculously saw the birth of three internationally acclaimed African American musics which would fuel and define the national culture: ragtime, blues, and jazz. The 1890s, termed "the nadir" of African American history by Rayford Logan, was a time when the racist backlash against African Americans was at a feverish pitch after the dismantling of Reconstruction, which was America's most serious attempt at establishing a multi-racial democracy. The 1890s saw a vicious intensification of extra-legal violence (including lynchings and bombings) against blacks, the erection of legal codes designed to curtail the freedom of blacks, the curtailing of due process under the law, and the segregation in employment, in housing, and indeed in almost all other aspects of life under Jim Crow, the US version of apartheid. So, decades after slavery African Americans still lived in the main without political franchise, without economic democracy. The one area under which they exercised meaningful control was culture. Among African Americans, then, there was the greatest flourishing of social and cultural formations that occurred during the nadir.

Just as there was a type of prefigured freedom-heaven on earth - in the music of the slaves that was not available under the physical, historical conditions, the music gave release of the innermost needs and desires. In the church there persisted the transcendence through trance, music, dance, and spirit possession. In the secular end of the spectrum in the jook joints, cabarets, and jazz clubs there was the improvisation of possibility through melodic improvisation and even group improvised form.

At the time that the three music forms began to attract international and critical attention, ragtime, blues, and jazz were not so neatly separated as the historiography of hindsight and categorisation might suggest. People that the history books have cemented as "jazz musicians" often used the term "rag" for instance to describe their music, and the first significant blues records were sung by blues goddesses backed by the likes of Fletcher Henderson or Louis Armstrong and other jazz musicians. By the jazz era the sacred world view that obtained during slavery was firmly a historical matter. Yet, music across various divides, including sacred/secular, continued to develop alongside one another, borrowing freely, and collaborating with and listening to one another. With the blues came first-person narratives, new dance forms, sexual mores, and entertainment designed to bring elegance and truth into the lives of black folk. Ragtime brought the piano, a type of European formalism, and self-conscious syncopation. Jazz brought 
improvisation, Swing, and the transformation of the function and technique of several European instruments to fit the dictates of African American music making. The hybridity of the music forms included all of these elements as well as the stylistic features of each music genre. It mirrored the social hybridity that resulted from the Great Migration from the rural areas to urban areas and from the South to the North, where down-home country values mixed with urbane sophistication.

These forms developed around the great invention of the rhythm section, which was built around the drum kit. Eventually, certainly by the turn of the twentieth century, jazz musicians invented the drum kit. Around this kit, the most innovative and important New World instrument, was built a fundamental organisation of music that was unique, the rhythm section. The rhythm section typically consists of the drum kit, a bass instrument, and a chordal instrument. This section improvises together in such a way that they determine the tempo, meter, and idiomatic feel of the music. It represents a compromise between the polyrhythmic drive of African music with its untampered melodies and differing rituals of repetition and the metered, functional harmony of Europe. While one can legislate against specific practices such as hand drumming or the use of African languages and religions, one cannot legislate against one's way of being or feeling in the world. The ontological integrity of blackness survived the Black Codes and presented the world with new forms and practices that performed a vision of freedom that could not be contained by prescription.

Much more than a compromise really, the drum kit enacts the African American foundation of modern music. Whether the music is jazz, or blues, or gospel or R\&B, hip-hop, or any of the countless variations of these, the rhythm section is the organising element in all of these musics. Throughout the world, most vernacular musics and popular musics are built around a rhythm section determining the feel, temperament, meter, and tempo of songs which feature singers and/or horns that improvise and perform compositions on top of the tapestry created by the rhythm section. Even countries with continuous hand-drumming musical traditions from Africa to the New World such as Cuba often incorporate rhythm sections alongside their drumming in their various popular musics. The jazz invention has changed the form and nature of the vernacular musics of modernity.

Thus, jazz has introduced a new way of modelling the world. The rhythm section combines improvisation, or individual expression, with the imperative of working jointly in groups to propel the music forward (a la Baraka, let us consider Swing, funk, both as verbs). Though this composite rests upon agreed upon conventions of cooperation, it nevertheless supports freedom, originality, and uniqueness. Indeed, this is one of African America's claims about what it means to be modern. The signifyn' practice of the soloist, along with the communal cooperation of the rhythm section necessary for the ensemble to Swing, be funky, or what have you, is a testament to the importance of freedom to a people whose origins are in various states of 
unfreedom. This notion of freedom is not to be confused with unfettered license. While the soloist is free to sing her song or play her own melodies, for the most successful or profound music there must be an organic relationship between her ideas and those of the rhythm section. This organising principle of jazz brings to mind the Zulu saying, umuntu ngumuntu ngabantu. That is to say, a person is a person because of people.

The most important institution with respect to the incubation and establishment of the music is undoubtedly the black church. This was so when the black church was largely underground during the antebellum period especially. Afro-Christianity has provided the universe in which African modalities could be ritually enacted in the United States. In the church music primary purpose was to enact what Lawrence Levine calls the sacred world view (pp. 3-18). This sacred world view which obtained in the music's prehistory during the centuries of slavery, when the music allowed visitation from the spirit world, where the paradigmatic actions of the culture's heroes and ancestors, be they Moses or Jesus, or even the General "Moses" aka "Harriet Tubman" herself could be invoked, and Divine visitation through the Holy Ghost could transform the nation's downtrodden and marginalised into heaven-bound Saints of God. These practices, including the musicking, were done by black people for black people. That is, there were no purse strings attached to the institution allowing control outside the affected group. Thus, this is a rare site where black autonomy reigned. The cultural and practical foundations for all the African American music of the twentieth century, from jazz and blues to funk and rap, were and are institutionalised in the black church.

Of course, there is quite a range of types of churches and congregations in black Christianity, and there is also a range in the degree to which a particular church or congregation might subscribe to the nation's dominant ideologies in the hegemonic dance between religious practice and thought and the class-inflected discourse that is expressed in individual instances. But in general, the cultural autonomy of the church has allowed it to be the de facto musical conservatory of Afro-America. Jazz, blues, funk, and rap are the most well-known music forms that can claim their origins within the black church. Music in the church serves the same function that it did during slavery, and indeed during the Middle Passage: it was the most plastic art form that served the ontological needs of African Americans. This is why Baraka would famously say that the blues is important to all legitimate jazz (Jones 1963). The term "legitimate" in this case is a racialised one, perhaps signifying on the long-standing practice of calling European Art Music (Classical Music) "legit(imate) music" while referring to improvising practices as "faking" it. What the term undoubtedly means, however, is that jazz is a music that was created to answer and present the psychic needs and cultural ideals of black people. That there is a legitimate history of jazz created by mostly European Americans is acknowledged, but differentiated from the blues-inflected jazz (no matter the "race" of the musicians playing it). An 
excellent example of this distinction is made in Edward Bland's film, "The Cry of Jazz", where the film's main character is explaining the meaning of jazz at a party where there are blacks and whites in attendance. The film has a didactic tone, but nevertheless manages to succinctly explain the causes, needs, and limitations of jazz as it existed in $1959 .{ }^{4}$ The proclamation in the film that "jazz is dead" is explained that the spirit of jazz necessarily remains vital even as its forms were then in need of further development to express freedom as imagined contemporaneously.

And it is so that the blues is the ur-form of twentieth-century AfroAmerica. It is the summation in secular form of the values of the antebellum period of the nineteenth century and the bold entrance into a radical modern self for twentieth-century African American women and men. Each subsequent American music form would be built upon the structures and aesthetic of the blues: Gospel, Zydeco, Second line, Dixieland, Swing, bebop, funk, trap, rock, etc.

The blues as a music form has the distinction in its classical form of being neither major nor minor in tonality. Rather, it is built upon the dominant seventh chord as a tonality. Classically, it begins with the dominant seventh chord, continues its modulation to another dominant seventh chord, and ends with the dominant seventh chord. In the functional harmony of the West, the dominant seventh chord is not a stable resolution, but rather a transitory, unstable chord that must be resolved, usually to a chord a fifth below, either major or minor. If one consults the 29-volume Grove Dictionary of Music on consonance one would find several articles, even one written in German. If one consults the word dissonance, there is a single sentence. Consonance and dissonance are not absolute terms, but are culturally and historically determined. What is considered consonant or dissonant varies from culture to culture and also over time. In the functional harmony that governs most of Western music a consonance is stable, (a resolution), whereas dissonances are unstable and must be resolved. The dominant seventh chord is the maximum state of instability and the V-I cadence that governs harmonic music is based upon the dominant seventh, which is the seventh chord built upon the fifth degree of the scale, resolving down to the tonic or home key. The instability of the chord is centred around the fact that there is a tritone between the third and seventh scale degrees. This tritone is either the most dissonant interval or the most interesting interval in the diatonic scale. It must, then, resolve to a stable consonance. In Western Art music, dissonance is something that must be handled carefully in service to an ultimate resolution.

The blues is built upon a different harmonic aesthetic. The tritone that at one point in the theory of European Art Music was called the devil's interval is not something that one must avoid or treat preciously in the blues. After all, blues legend Robert Johnson was said to have made a deal with the devil to attain his musical mastery. Though the fact that he met the devil at the crossroads surely points to the fact that it was not the Judeo-Christian devil, but rather Elegba of the Yoruban pantheon. Elegba (also known as Eshu or 
Eleguá in Latin America) is encountered at the crossroads and is the orisha that governs entry. Erroneously seen as the Devil by Christian moralists in the New World, Elegba is actually a trickster and as such is beyond good and evil, certainly not such a Manichean figure as the Devil.

The blues in its ethos and practice cuts against the normative grain of American culture. For instance, it flaunts the sexual mores of the dominant society. During the 1920s when a blues craze brought to the world's attention artists like Bessie Smith and Ma Rainey, these artists and many others openly practiced bisexuality and lesbianism, for instance, and included these themes in their music. Coming from the rural and urban black proletariat, the music was decidedly against the sentimentality of US popular culture. The boy-meets-girl-and-lives-happily-ever-after trope of romantic songs was replaced with honest portrayals of not only love and happiness, but also betrayal and loss. In a music form that went against the implied closure represented in functional harmony, the blues gave voice to unapologetically black points of view about the lives, real and imagined, of regular non-idealised black folk, completely absent of the need to resolve social tensions by invented fictions.

In jazz there is a saying, "it's not what you do, it's how you do it". The classic blues built its harmonic form around chords that are in fact the mainstay and foundation of European functional harmony, the tonic, the subdominant, and the dominant. In the blues, however, the expectations of this I-IV-V harmony are problematised by its choosing what heretofore was an instability as the basis for its form. It also bolsters the cyclical nature of the music form and thus implies that there is often no neat resolution to be had. This reliance upon repetition and cyclicality has other examples within the Black Atlantic. One striking example is mbaqanga, another twentiethcentury Afro-modernist music is from South Africa. Mbaqanga also relies upon the I-IV-V sequence as its harmonic basis. In fact, young musicians routinely refer to both the form and the way of playing as "one four five". Mbaqanga's relationship to South African jazz is quite similar to the relationship between the blues and African American jazz. Mbaqanga incorporated the message, musical and otherwise, of other contributing streams to South African jazz such as Marabi, and set the aesthetic and stylistic tone for much of what is most compelling about South African jazz. Also, like the blues, it highlights cyclicality. Despite its functional basis, mbqanga relies upon repetition and danceability to be a successful act. That is, the teleological assumptions normally implied in Western functional harmony are suspended for both the blues and mbqanga. Added to this non-sentimental approach to musical meaning is the dance beat orientation of both music forms. In each case a newly urbanised proletariat existed as an oppressed and despised people. The terpsichorean emphasis in the music on joy, and on black bodies, and pleasure was in itself a bold insistence upon the humanity of black people, as well as their relevance in a cosmopolitan modernity (Snead 1998, Jaji 2014, pp. 1-23). 
Both the blues and mbaqanga are ur-tropes that helped to map the intellectual development of Afro-Atlantic cultures. These musicians were in a sense self-conscious, Gramscian organic intellectuals. In 1966 South African writer Lewis Nkosi commented on the similar place in cultural history that the two forms share:

The industrial culture in South Africa especially, more than anywhere else on the continent of Africa, provides an ambiance where fusion between the Western and the African heritage has gone so far as to produce a new urban idiom. Mbaqanga, upon which South African modern jazzmen are constantly feeding, is really a fulsome (sic) of American jazz forms with some of these African strands I have enumerated. On any day in Johannesburg you can see shabby unemployed young Africans dancing on the pavements of the city to this jive music which is relayed by loudspeakers from inside record shops. If they survive the constant police raids, some of these kids, like Miriam Makeba, have gone on to conquer the world stage.

(Nkosi 1966:36 quoted in Kubik 2017)

In roughly contemporaneous times, the blues and mbaqanga became the music of the black proletariat and urban poor of each respective nation. Both forms would be dance beat-oriented. Both would be disseminated through recordings. And both would provide the well spring from which future distinguished jazz musicians would drink to tie to a tradition their future innovations.

And these innovations must need come in order that the music reflects and influences the expanded social conditions, and to meet the demands of the people with whom and for whom the music was created. Throughout the rest of the century in both countries the "common practice" musical parameters of the music would become increasingly free. Free in the jazz sense of an expansion of what is permissible, a redefining of the scope of practice-deemed idiomatic. For the blues, and in South Africa mbaqanga, the tuning of melodic content deviated from the diatonic system in ways that are consequential. The placement of blue thirds and sevenths in the melodies introduces a worrying of the very notes that determine whether a chord is major, minor, or dominant. This tendency toward elision of functionality is furthered by the fact that either the major or minor third can be perfectly idiomatic no matter the quality of the chord type. The hierarchy of tones within the diatonic system is thus subverted in the blues in much the same way that functional harmony is refashioned in a form that is based upon dominant chords. According to Gerhard Kubik, the partial-based tuning system used in various parts of Africa proves resilient in various encounters with Western instruments and music. It explains the blues tonality and intonation of the late nineteenth and early twentieth century blues and also that of mbaqanga. Listen to tenor sax maestro Duke Makasi's "blue sevenths" 
in "Inhlupeko" (Suffering) by South Africa's Soul Jazzmen. ${ }^{5}$ Interestingly, "Inhlupeko" shares the same music form as the jukebox hit record that became a famous anthem in the anti-apartheid movement, "Yakhal' Inkomo" by tenor saxophonist Winston Mankunku Ngozi. Translated as "The Cry of the Bull" "Yakhal' Inkomo" also uses mbaqanga (also in Eb major) in the main theme and Swing over jazz standard ii-V-I harmonies during the bridge. The cry of the bull also speaks to the sufferings of black people; the cry of the bull, an important part of the slaughtering ritual in the isiXhosa culture, represents its distress at seeing its fellow creatures slaughtered. Thus, in the same year South Africa's two leading jazz tenor saxophonists wrote and recorded a protest song written over the same form. It's as if John Coltrane had written an analogous suite in 1957 as Sonny Rollins' Freedom Suite.

The first real flowering of jazz was centered in New Orleans at the turn of the twentieth century. The collapsing of the tripartite racial system in which Creoles were distinct from those categorised as either black or white resulted in Creole music practice melding with black musical practice. The raw improvising and the blues tonality of black musical practice joined with the musical literacy and formal complexity of Creole music. At its best this innovation in practice and form created artists like Jelly Roll Morton and Louis Armstrong who both delivered some of jazz's first recorded masterpieces. The history of jazz as heard in its canonical recordings reveals that in musical parameters, such as rhythm, melody, harmony, and timbre, each generation of jazz musicians routinely expanded their sense of freedom through the techniques and practices of the era.

If the 1910s and 1920s gave rise to a polyphonic response to the hybridity and cosmopolitanism of black New Orleans society, the 1930s and 1940s saw the entrance of black music into mainstream white society through the dance craze around Swing music as a genre. This occurred during the first waves of the Great Migration when thousands of blacks left the South and travelled Northward and Westward, altering the demographic composition of America's industrial cities as they did so. While the North did not prove to be the Promised Land it was expected to be, there was to some degree a welcome relief from some of the more onerous aspects of Jim Crow law in the South.

Swing was a music dominated by big bands and as such had greater structures, often with written music, designed to have many musicians play at once with clarity and order. While the various horn sections, saxophones, trumpets, and trombones might play homophonic passages, usually in call and response counterplay, there was a greater emphasis also on the virtuoso improviser. With the adoption of jazz as the pop music of the day, the dance music for the youth, Swing witnessed a degree of Americanisation of jazz and African Americanisation of US mainstream culture.

Star soloists, most emblematically "Prez", tenor saxophonist Lester Young, began to expand the possibilities of jazz improvisation. In earlier 
years, Louis Armstrong became an innovator when he gave improvisation greater harmonic relevance and rhythmic fluency in his virtuosic solos of the 1920s. Prez became one of the first major soloists to use the cool approach in contradistinction to the hot soloists that dominated the tenor saxophone such as Coleman Hawkins and Chu Berry. Young also liberated the soloist from the restrictions caused by the vertical arpeggios of the chord running style of improvisation. Now the melodic content could be more horizontal, thus freeing the soloist from the burden of articulating every single chord in detail. The hipness that Prez embodied relied in part on his ability to float above the harmonies through rhythmic inflection and harmonic implication. When we listen to the extant interviews with Lester Young, we can hear the insistently hip and modern voice he chose to speak in (it almost sounds as though instead of the 1950s he could be speaking in the 1970s or indeed today), mirrored in the vocabulary of his improvisational approach.

Perhaps, the capstone of Afro-modernism was in the 1940s-1950s revolt of "modern music" (so named by the musicians themselves), known canonically as bebop. Riffing on Ralph Ellison's observations about bebop's uncrowned king, Charlie Parker, Eric Lott says in "Double V Double Time: Bebop's Politics of Style" that 'Bebop was about making disciplined imagination alive and answerable to the social change of its time' (Lott 1988). Ellison explained Bird's grace and musicianship with a poet's grace, but also ruminated about the inner meaning of the bebop generation's muse.

Parker operated in the underworld of American culture on that turbulent level where human instincts conflict with social institutions; where contemporary civilized values and hypocrisies are challenged by the Dionysian urges of a between-wars youth born to prosperity, conditioned by the threat of world destruction, and inspired-when not seeking total anarchy - by a need to bring social reality and our social pretensions into a more meaningful balance.

(Ellison, p. 49)

Ellison, in his review of Reisner's biography of Parker, gives a more penetrating analysis of what bebop meant in artistic terms than virtually any contemporary writer, despite what we know about his disdain for the modernist from his now published private correspondence with his friend and mentee, Albert Murray. Bird might not have been Ellison's personal taste, being mired in the aesthetics of the Swing era, but he understood the music brilliantly in terms of what was at stake artistically. Lott builds upon this to reveal the political significance of bebop. He ties the music to the anti-war sentiments of black and Latino youth cultures and the counter-cultural aspects of the modern music movement. The reluctance of black people to participate in yet another capitalist war that bolstered European imperialism 
was assuaged by the Double V campaign — victory against fascism, at home and abroad. And like Ellison, Lott ties these phenomena to the virtuosity of the music.

Both writers see bebop as a revolt against mainstream American music and social mores. The modern music movement did represent the most thorough going intellectual achievement in jazz music, and is studied by all jazz students and would be musicians desirous of a classical jazz technique. The music dazzles with its extension of rhythmic, harmonic, and melodic possibilities, its use of the upper structures of the chords, its knowledge and utilisation of the classical world of music and the vernacular musics of the day including the blues, and, of course, its blinding virtuosity. What is only hinted at in Ellison's remarks, however, is that the modern music movement was an attempt to outperform whites at their own game. These musicians were committed to upholding the logic of functional harmony, only they did it with more complete harmonic understanding, with more complex rhythms and melodic structures, and at faster tempi while improvising.

A stunning achievement, but still somewhat within the musical universe of European functional harmony. This was in keeping with the mode of contemporaneous political activism and protest. The 1950s saw the cresting of the historic Civil Rights Movement (CRM). The CRM was concerned about the racist exclusion and segregation of America in its economic, social, and political life. While black people often could not vote, could not live wherever they desired, could not work in whatever profession they aspired to, could not attend schools of their choice, and so on, the de jure laws of the land said that they could. It was forcing America to live up to its promise that the judicial and social aims of the CRM were based on. And because of this there was a perceived need to continue with the politics of respectability that obtained in black political and activist social circles. Protesters and activists obeyed the law and showed better decorum than those whom they protested against. Non-violent civil disobedience in the face of lawless vigilantes and the most demeaning and spectacular violence. They took the fight to the courts and pushed for legislation. That is, they obeyed the laws and proved their humanity by living up to and exceeding the normative expectations for first-class citizenship. Similarly, the beboppers' ultra-modernist revolt continued to adhere to the rules of functional harmony even if their harmonic and rhythmic palette was greatly expanded. The combination of this erudite approach to music with the vernacular urgency of the blues marks this classical music as a capstone in Afro-modernity.

It would take the succeeding generations, however, to bring the musical revolt to full-fledged revolution. The Free Jazz and New Thing movements from the late 1950 s to the 1970 s would usher in the most thoroughgoing critique of Euro-modernism in jazz history. The post-bop experiments of artists like Ornette Coleman and Eric Dolphy began to loosen the functionality of the beboppers' praxis. By the 1970s after the October Revolution and the 
ascension of artists like Archie Shepp and Albert Ayler, following the lead of Coltrane's late work, the New Thing ushered in an astonishing flowering of music as part of the Black Arts Movement.

This is the music that eschewed the practices and expectations of European American music in the most far-reaching way. It was more than symbolic that often the piano was absent in these new ensembles, and certainly functional harmony was no longer adhered to. The sounds of the horns regularly included shrieks and moans, within and beyond the normal range of the instruments. These moans have always been part of Afro-American music. But the new jazz practice privileged these sounds over the cleanly articulated gestures of the bebop movement. Also, the regular propulsion central to Swing was often abandoned as was the use of meter. Tempered intonation, long held as a measuring stick, was no longer always relevant. The explosion of sounds and practices announced a resolution to play on the musicians' own terms and to not be restricted by mainstream values and to not be beholden to whiteness, culturally or politically. The new coterie of musicians seemed to highlight more than a generational divide. It was as though a political manifesto was being issued, something that was explicitly alluded to by the writings of Archie Shepp, for instance, the explications of the new music by Black Arts writers and theorists of the culture such as Larry Neal and Amiri Baraka, and the naming of Bill Dixon's new music series as the "October Revolution", literally invoking the Bolshevik revolution.

There was political and social organisation that accompanied the stylistic advances in jazz. In Chicago the Association for the Advancement of Creative Musicians (AACM) was founded, in St. Louis the Black Artist Group (BAG), which included other artists such as dramatists and sculptors. In Brooklyn the Collective Black Artists (CBA), in Los Angeles the Union of God's Musicians Artist Ascension (UGMAA), and others were started to provide the support for the new music for which the established industry had no place. Often the new music was played in privately owned lofts or community spaces. So, the geography of the industry shifted to accommodate the new music and the new organisation of musicians.

The new musicians were tired of trying to be recognised by the club owners, critics, and festival organisers, and thus took matters into their own hands, while creating a music that was fresh and exciting. This was part of the Black Arts movement, itself the artistic wing of the Black Power movement. The Black Power days were different in scope and method from the political work during the Civil Rights Movement. Where the CRM was centred around lawfulness and respectability toward the end of winning a moral victory over racists to force the nation to amend its ways, the Black Power days saw young people who felt that those methods were exhausted and the victories hollow. All deliberate speed, the mandate that the courts tasked America with in desegregation was ignored in both the South and elsewhere. Young people took to the streets rather than the courts, often after horrific incidents of racist police brutality. These were the days of urban 
insurrection in which scores of cities erupted in flames and property destruction, claiming lives, with thousands of arrests, millions of dollars of property damage, the loss of control of the cities, and even deaths. Just as young activists began to feel that new methods were necessary to achieve their political ends, new jazz musicians often believed that new ways of playing were necessary to invoke the spirit of the times.

In South Africa there was a spate of urban uprisings as well, often reductively called the "Soweto uprising". In fact, the black youth across the nation participated in this rebellion. Ostensibly about the students' refusal to be instructed in Afrikaans, it was a rebellion against the Apartheid government and its way of life, its scientifically systematic oppression of the masses. Concomitantly, in music and poetry there was a Black Arts movement to accompany what would be also known in South Africa as the Black Power movement. Artists such as saxophonist Robbie Jansen and poet Lesego Rampolokeng would rise to prominence giving voice to the rage of the oppressed and the urge for freedom felt by the black masses.

During the 1980s there was a retrenchment of the revolutionary activities of the previous decades. In the United States, there was a rise of black conservative thought that reached the elite levels of academia and government. Public figures like economist Thomas Sowell and Supreme Court Justice Clarence Thomas were certainly from a different political stripe than predecessors such as Thurgood Marshall (whom Thomas "replaced") and Angela Davis or Cornel West, both public intellectuals and social theorists. In jazz the decade saw rise to the top of the industry a group of musicians who were classists rather than mavericks. No longer were the elite jazz musicians searching for revolutionary utterances; they were reviving and championing an earlier, classic phase of jazz history. This was a new occurrence-the youngest most talented black jazz musicians playing the music of an earlier generation instead of reinventing the received practices and language. No longer was innovation the yardstick by which they were meaningfully measured. It was often presented as a technical matter to a large extent. Young musicians had to prove how technically proficient they were especially in the context of the neo-hard bop movement. The undisputed leader of this movement, trumpet prodigy Wynton Marsalis, not only proved his mettle in the Jazz Messengers, led by veteran band leader, Art Blakey, but also proved to be exceptional in European Art Music as well. At 19 he won Grammys in both categories.

Mr. Marsalis is the world's most powerful jazz musician in history, even more so than Duke Ellington. He wields enormous institutional power and influence, especially since he has headed the jazz program at the prestigious and well-funded Lincoln Center. As he solidified his position as the official voice of jazz, Marsalis cleared the air by drawing the lines of the canon decisively and clearly. No longer considered canonical were the right and the left. That is, he dismissed most of the experimental pathways explored, nor the electronic, and especially not the commercially oriented were now held 
in suspicion if not outright derision. It seems that in the decades-old feud between Ralph Ellison and Amiri Baraka, the two most influential black writers on jazz, Ellison's view prevailed. The elegance of the art form and the maintenance of a veritable tradition with canonical recordings and repertoire bands are more the order of the day than the revolutionary incendiary music championed by Baraka. While Baraka was a fully fledged music critic in a way that Ellison was not, it was Ellison's view that travelled through Albert Murray to Wynton Marsalis, the dominant voice on the contemporary jazz scene both as practitioner and as commentator.

The jazz neo-conservative movement came to prominence simultaneously with the hip-hop movement. It was in the hip-hop art forms, including rap music, where the proletarian, urban black agenda was being discussed and mused over artistically. And its reign continues till the present, as does rap music if not all of the various forms that came to prominence at the inception of hip-hop. Perhaps, the neo-hard bop direction of jazz has allowed hip-hop to take not only the reigns of youth culture in pop music but in jazz as well. One of the most interesting post-modern iteration of jazz is Kendrick Lamar's "For Free?" The fusion of gospel, rap, and jazz is used to stunning effect. Lamar's rap is reminiscent of a type of 1950s Sammy Davis Jr.-esqe type of patter. The music settles mostly into a modal vamp a la Coltrane Classic Quartet minus Coltrane. The words in the lyrics are not respectable, and employ profanity as part of its artistic arsenal. In this risqué diction, one hears the language of the streets and the philosophy as argued among the black working class. One is reminded that jazz and blues at their inception were not respectable genres, were not part of the mainstream culture in the way that it has achieved under the leadership of Marsalis. Initially, not only did white journals and taste-makers object to the music but the black middle class was not always supportive either. Someone squeamish about the format, diction, and vocabulary that Lamar uses might easily miss the social and political messages that the song is ultimately about. This in your face, irreverent use of the vernacular that is a call for freedom that is cathected with libidinal energies while being hyper aware of the various levels of unfreedom that exist-socially, politically, economically. Perhaps, it will take a person like Lamar to bring the sense of urgency and danger, the revolutionary fervor that has been the birthright of the music for over a century.

While I agree with Dr. Cornel West in the opinion that it is in the tradition of music that houses the most thoroughgoing interrogation and critique of the West, the jazz imaginary also goes beyond music per se and includes practices in other arts, most especially the literary arts. In black literature, the jazz imaginary has significant achievements and developments in poetry, short stories, novels, essays, biographies (especially autobiographies), and of course the articles and books that deal with jazz analysis and history.

In the case of poetry, much is known and acknowledged about the symbiosis that can occur between the two art forms, inasmuch as poetry in some 
sense directly correlates with music. There is a large body of literature that explores this, so my remarks will be brief. ${ }^{6}$ Most importantly, both forms, improvisatory music and poetry, explicate through inference. And then there are the more obvious ingredients of rhythm, cadence, meter, voice, and so on. And even further in a tradition which is tilted in importance toward the oral rather than the written forms of poetry, timbre and energy become other significant musical ingredients. To witness first hand "Somebody Blew up America", by Amiri Baraka or Lesego Rampolokeng reciting "Tears of Marikana", is to gain important emotional and semantic content not always evident on the page. Not just the sound of these poets projecting with the charismatic craft that musicians employ, but also the aesthetic stance of the work, which is to say the political and artistic reality invoked, is more fully realised in its oral form. Baraka's insistent repetition of "Who?!?, who???" as he slams his fist upon the lectern while listing the last 500 years of Imperial conquests of the West (especially the United States) reminds me of a gospel preacher in the Afro-Christian tradition. The momentum in the rhythm and cadence along with the idiomatic use of repetition helps the listener understand the gravity of the words, of the magnitude of the history that is being interrogated. Similarly, in South Africa, Lesego Rampolokeng's carefully crafted poem, "Tears of Marikana", does indeed mark the solemnity of the strikers' purpose and preparation, their brutal assault by the state sanctioned police force, as well as the systemic nature of this oppression, its representation of the failure of (state) capitalism in South Africa. His performance, along with the accompanying music, lends gravitas to the poem. The introduction of capitalism to South Africa is a particularly vicious one, one that encapsulates the theft of land, the systemic undermining of the black family, the enforced status of lumpen proletariat, and other horrors. We are so much living within this reality that it is easy to be numb to it. Worse, we can lose sight of the fact that while this arrangement precedes Apartheid (our current favourite designation of White Supremacy) and goes back to the origins of South Africa as a nation state. His performance of "Tears", however, shows the disgust toward the captains of industry; it highlights not just the exploitation of the workers, but the very inhumanity of those who created their desperate state and those that massacred them for daring to request a living wage from a company making billions of US dollars in profit. Above and beyond the indictment for political and economic oppression, the jazz performance rendered through Rampolokeng's poetry brings us into consciousness of the human dimensions of the conflict.

$* * * * * \quad * * * * * \quad * * * * *$

Fiction, especially in short stories, novels, and drama, is a very fertile ground for the jazz imaginary. There are of course many fictional tales where jazz or jazz musicians are featured. But there are also stories in which jazz becomes more than a prop or background; in these stories, jazz is featured as 
a character, capable of affecting and progressing the plot through its own agency. These stories are fascinating for what they add to the jazz imaginary. Consider Ann Petry's "Solo on the Drums", a short story that hints of a fictionalised performance by a drummer in the Count Basie band. Kid Jones takes the solo of a lifetime. The power of his solo is not rendered nor heard in technical musical terms. Rather, it is heard as a force of nature, like thunder. Its genesis is bound in the need to transcend the ache of the drummer's possibly being made a cuckold by the band leader. Rather than mimic the emotions secondary to the treachery of betrayal, the music brings Kid beyond his sorrows as he fashions music that is powerful and potentially healing. Petry is an author that understands quite well that the blues impulse while "fingering against the jagged grain" of pain, as Ellison would have it, musically is closer to transcendence and even joy than it is to sorrow.

Another way in which jazz is personified in short fiction can be found in Baraka's "Screamers" which includes a fictionalised account of a performance by Lynn Hope (also known as El Hajj Abdullah Rasheed Ahmad). The context is a nightclub where a set of competitions are taking place. One is an implied contest between the honking tenor saxophonists-Big Jay (Big Jay McNeely? - a prime exemplar of the honking tenor style) and Lynn Hope - and the other, a class competition between the black middle class and the black working class. The tenor sax battle is a staple in jazz practice, but in this narrative it is elevated to class struggle as represented musically. Baraka, born to the manor of black middle-class culture but deeply distrustful of its political and especially cultural worth, has the narrator ridicule the class consciousness and colour-struck politics of this most maligned class. While Big Jay is playing, the contest between the classes is described from a patriarchal view of who will score with which women, light skinned women from "our camp" or women from "those niggers". Lynn Hope's performance results in the people carrying him outside and bringing a procession through the streets. The class contest is no longer about who will win the game of night club romancing, but rather about who will take to the streets in protest and who will walk away from the politicised action. The police come and attack those "Biggers". That is, Richard Wrights' protagonist from his Native Son, Bigger Thomas, is referenced to underscore the inchoate protest carried out by the Screamers. ${ }^{7}$ Jazz is thus not only a site for the imagining of freedom, but a catalyst for political action.

Black South African novelists have a very distinguished tradition of jazz writings, of using the music to frame the social and political needs of their fictional worlds, and as a commentary on the aspirations toward freedom of black people in general. Interestingly, even though South African has a more than century long history of jazz performance, ranging from the music of nineteenth-century minstrel troupes enshrined to this day in the Coon Carnivals of Cape Town, to the modern music of Kippie Moeketsi, to the avant stylings of Andile Yenana, the novelists are decidedly and self-consciously 
Pan African in their rendering of the jazz imaginary. Four novelist in particular stand out: Mandla Langa, Mongane Wally Serote, Fred Khumalo, and Nthikeng Mohlele.

Mandla Langa's Rainbow on a Paper Sky uses the music to provide understanding about the political trajectory of its three protagonists. The novel is a bildungsroman of three siblings and also a bildungsroman of a black village during late Apartheid. The music can inspire a joining with the spiritual and political expressions of the community, or could be a back drop for self-interest, or an entry into a transcendent consciousness. The music is not a figure for sainthood; the sibling who became a professional musician was a political sell out, collaborating with the apartheid government to ensure his celebrity. Rather, in Langa's treatment of the music we are made to understand that the music and the musicking actually enact a set of understandings that can be accessed with differing levels of profundity and efficacy. Through important encounters with the music one sibling becomes a prophet and another an activist. In his short story, "The Naked Song" places the figure of the failed musician and would be revolutionary in apposition to the Soul music that inspired hope for the younger generation. ${ }^{8}$ In The Memory of Stones, Langa also extends the jazz imaginary to interact with what could be called South African magical realism. The reality of the interaction between the ancestors and living actors in black South African ontology, the living and the "living dead" allows the music to also bridge these realms into one world. That the ancestors are on the side of justice and provide succor for the politically righteous (the community of black folk trying to survive the murderous machinations of first the colonial government, then the apartheid regime, and finally corrupt developers) lends metaphysical support to the imaginary of freedom.

The metaphysical strength of the jazz imaginary was famously treated earlier in South African fiction through Serote's To Every Birth Its Blood, which is written in two parts. The first a torturous rendering of the atrocities of apartheid and its effect upon a single protagonist and his family. $\mathrm{He}$ is rendered impotent in his ability to connect with his job, then his wife, and then his mistress, in particular, and eventually life in general. The back and forth of his descent and his struggles against it, his brief heroic attempts at life are narrated through music. The patron saint of the novel is clearly John Coltrane, but this is held in contrast with Miriam Makeba, Jonas Gwangwa, and other South African artists. The American jazz narrates and animates alienation, whereas the South African jazz artists provide the same functions for domestic reconciliation. Grippingly, the stalemate between alienation and inaction is broken in part two of the novel with an eruption of Soul music. With this music the protagonist becomes the black community and the alienation and impotence of Tsi, the protagonist of part one, is replaced with the political organisation and sexual urgency of the youth. 
If Coltrane is prominent as the muse of revolutionary South Africa and its struggles against white domination after the Nationalist government took reign, Miles Davis appears as the patron saint for literary protagonists in post-1994 South Africa. In Khumalo's The Longest March, depicting the forced march of the Zulu people in 1899 in preparation for the Anglo-Boer War in South Africa, John Coltrane is again the patron saint of the work. In fact, the book is divided into the four movements of Coltrane's most acclaimed work, A Love Supreme (the original title for the novel), "Acknowledgment", "Resolution", "Pursuance", and "Psalm". This is an anachronism of sorts, but it is consistent with practice of Coltrane's spirit aesthetically overseeing the resistance to the colonial despotism visited upon black people.

But in Khumalo's earlier novel, Bitches' Brew, which deals with postapartheid era of South Africa, the patron saint is acknowledged by both the author and the protagonist (who is also one of the narrators as Bitches' Brew is an epistolary novel) emphatically to be Miles Davis. Similarly, Mohlele's two jazz novels, Small Things and Illumination, both attest to a dystopian society devolved from the halcyon spirits of liberation in 1994. Davis, dubbed the dark prince of evil by some, is an artist with the type of ambiguity necessary to represent the ways in which one of the grandest modern heroic efforts is also accompanied by terrible greed and corruption. With Mohlele we see a further development of the figure of the failed musician explored earlier by Mandla Langa, and by synecdoche a failed society and nearly a failed state. Whereas Langa's failed musicians highlight that it is the communal agency of the art form that can engender liberation rather than subscribing to the hagiography of the artist, Khumalo's and Mohlele's use of the failed artist reflect the ways in which the society and the state have been compromised. These fictional artists live in a time of great social inequality, violence against women, state corruption, misogyny, and capitalism run amok. Behind the scenes, of course, is the compromise made at the very beginning of South African democracy in which black labour continued to be marginalised and abused.

The spiritual aspirations of the musicians are vulnerable to the social realities in which they operate, and in some ways doomed to failure. It is very interesting that Miles Davis is positioned as a patron saint for the protagonists in these novels. Davis is universally celebrated for his creativity and importance in modern jazz. He is also held in suspicion ethically because of his aesthetic choices, especially his merging with rock. There is an ethical back story as well; Miles Davis was an abuser of women. Couple this behaviour revealing his personal demons with the notion that he was willing to sell out musically, as well as his devil may care attitude toward propriety (including the prudish notion of the critical establishment that he should not join forces with the rock revolution of the 1970s), does indeed make Davis appear to fit in interesting ways with narratives that deal with aesthetic ambition in the face of the dyad of societal decay and political and economic 
betrayal. Within the novelistic traditions of modern-day South Africa, Miles Davis' example that greatness does not necessarily imply perfection gives space for a departure from the hagiography that Coltrane still enjoys to this day. From his penchant for vulnerability and willingness to even miss notes (notes whose "absence" are still pregnant with meaning), Miles Davis" praxis opens a dialogue about the nature of competence, and the ontology of substance in music. Mohlele and Khumalo are asking the same questions within the jazz imaginary with respect to post-apartheid South Africa.

$* * * * * \quad * * * * * \quad * * * * *$

Within the jazz imaginary the jazz autobiography is especially illuminating as they can go beyond the preoccupations of professional biographies which concentrate on who played what with whom where and when. It's not that the autobiographies do not concern themselves with this type of documentary function (though on occasion such as Charles Mingus' Beneath the Underdog, they very pointedly do not), but they are more firmly in the realm of the jazz imaginary as they attempt to make meaning of their involvement in jazz, and even contemplate the importance of the music writ large. Mingus' autobiography is significant for the fact that in one way of understanding it the work is a series of meditations about the nature of God and divinity particularly in the dialogues between Mingus and Fats Navarro. Embedded within traditions of the picaresque novel, replete with pornographic episodes and old-fashioned African American toasts and lies, the pronounced thread of divine exploration in the autobiography is perhaps a surprise. It is less surprising when the conglomeration of writing styles is compared to Mingus' oeuvre as a composer and band leader. His compositional palette is perhaps the widest among the major American composers, and his praxis as a band leader is not without a certain amount of deliberate chaos as well as exquisite control. Perhaps Beneath the Underdog is exactly the type of document we should expect from Mingus as he attempts the ambitious task of considering the real meaning of jazz from the point of view of one of the music's innovators. Charles Mingus is one of the greatest bassists, band leaders, and composers within the tradition, yet his autobiography chooses rather to emphasise the meanings of the tradition and praxis of jazz, and as such goes far beyond these concerns which would normally be highlighted in a biography. ${ }^{10}$

Similarly, Treat It Gentle, by Sidney Bechet, engages the jazz imaginary and its insistence on freedom through its framing of "good music" as always being related to the message of "Omar's Song". Bechet retells a Louisiana folk tale about the slave musician, Omar, but tells it as if Omar was Bechet's actual grandfather. The tale is a romance in which a jealous slave owner is in competition with Omar, the drummer and dancer of Congo square fame, for the affections of a woman, who is also a slave. The tale is fascinating as the narrative goes from Congo square dancing to the free maroon society 
in the swamps, and back again to the slavocracy of Louisiana. The various classes represented in the characters of the romance include a treacherous slave who is a snitch as well as heroic blacks who helped the protagonist. There is also the lecherous slave owner with murderous intent. The music of Omar is about freedom, both aesthetically and literally, and it is cathected with the romance of love as well. By framing all of the music in this tale of slavery and freedom, betrayal and heroism, including the ultimate sacrifice, is quite an explicitly political interpretation of jazz music as told by one of the actual fathers of the music.

This may well be why the claim, made by Gunther Schuller and others, that Louis Armstrong is the first great improviser in jazz is so ubiquitous; in addition to Armstrong's preeminence, his persona proved more palatable for the desired narrative surrounding the music. (Remember all of the first critics and authors on jazz were white.) Bechet has a plausibly legitimate claim to that honour, but his unsavoury behaviour (Bechet had a penchant for gun play) and his political views make him more problematic as a symbol as one of the fathers of jazz, perhaps as important as Armstrong and Ellington who are the undisputed progenitors of the art form. While Armstrong's importance and greatness cannot be exaggerated, and also noting the nuanced and complicated nature of his self-presentation, there is a difference in the political import of Bechet's autobiography and those of Armstrong. In fact, Bechet, though technically a Creole who spoke French, identified both himself and the music as being from Africa unlike, for instance, Jelly Roll Morton, whose maturity as a composer predates even Ellington. Identifying the music as African, and especially framing the music's meaning as being born in the crucible of slavery, makes it harder to fashion jazz as a symbol of American nationalism with Bechet as the founding father than it is with Pops who is his contemporary.

The tradition of black critical engagement with jazz has been bifurcated, reaching a crisis point with the publication of Blues People, the first book length study of the music written by a black author. One wing begins with Amiri Baraka, and includes such figures as A. B. Spellman, Larry Neal, and now Kalamu Ya Salaam. For these commentators the music is revolutionary and freedom seeking. The other, now dominant, wing starts with Ellison, and includes figures such as Albert Murray, Stanley Crouch, and now Wynton Marsalis. For these writers, jazz is chiefly characterised by its elegance and craft. For these writers, jazz is the music of America rather than the subaltern voice of the American slave. ${ }^{11}$ With the apotheosis of musical phenomenon, and inheritor of this line of critical engagement, Wynton Marsalis, jazz as America's music is presently the official interpretation of jazz as preached through the most powerful institutions of the industry such as Lincoln Center, the Smithsonian, the Pulitzer Prize, etc., and perhaps more importantly myriad college syllabi throughout the nation. It is important to realise that this was part of the price of mainstream acceptance of the art form, and that as ever there is an underground, unofficial theory and praxis of jazz whose history goes back to the Middle Passage. 
This interpretation of African American culture and music, as originating most substantially in slavery, remains alive through a number of extraordinary contemporary writers. Among the most extraordinary are Nathaniel Mackey, Fred Moten, and Saidiya Hartman. First comes Hartman (1997) who investigated the subjection African Americans-even the most commonplace and quotidian ways in which it was enacted, endured and the ways in which it informed identity and even resistance. Moten (2003), taking his cue from Hartman, investigates the ways in which the aesthetics of the black radical tradition cut against, and utilise, the horror and pain of slavery and subsequent oppression. In particular, he is interested in the ways in which the black radical tradition and black aesthetics have their literary origins in the screams of Aunt Hester, who as a slave is the victim of rape and physical assault, as narrated in Frederick Douglass' autobiographies. Hartman's and Moten's works are among the most sophisticated discussions of black radical aesthetics available. For me, however, one of the most delightful investigations is enshrined in Nathaniel Mackey's Bedouin Hornbook (and of course Djbot Baghostus's Run, Atet A.D., Bass Cathedral, and Late Arcade the following editions in the series, From a Broken Bottle Traces of Perfume Still Emanate). Through this series Nathaniel Mackey is able to give a glimpse into the experiences of a musician and the investigations of a scholar in one character.

Mackey's Hornbook is an epistolary novel. We only read N's letters to the Angel of Dust, though her letters are referenced in those written by N. N is a peripatetic multi-instrumentalist who is a member of the Mystic Horn Society. The group travels around on the west coast practicing, performing, discussing, and developing their music. $\mathrm{N}$ is a philosophically inclined, well-read, and deeply listened musician/intellectual who has heard claims including the mystical ontology of the music itself from the point of view of the musicians while simultaneously referencing the iconic musicians, performances, and recordings of an edgy musician who is unusually erudite. It is a masterful tale that will touch on the reader's sense of wonder and keep the jazz imaginary in play at all times.

Mackey's character, $\mathrm{N}$, reminds us that the jazz imaginary also includes social dance, political communities, and activism. Ultimately, it is involved in a set of cultural/intellectual/spiritual practices that are codified in the music but which operate in wider fields of influence and praxis. The 1960s and 1970s were spectacular times for the jazz imaginary. Within the music itself was perhaps one of the greatest revolts against European and EuroAmerican hegemony. One of the results of this ethos was the organisation of musicians and artists in order to better present and promote the music, but also for the added power of political cohesion.

The most successful, in the sense that it still exists today, is the AACM, the Association for the Advancement of Creative Musicians. It has expanded from its home base in Chicago to New York, and continues to be active and important. The definitive study is George Lewis (2007) in which we learn 
from his meticulous notes and recordings of the AACM over years. We see from an insider's viewpoint how this organisation of black musicians from the South Side of Chicago made a mark and changed the course of experimental music. The same can be said for BAG, the Black Artist Group from St. Louis. It was only active from 1968 to 1972, the height of both the Black Consciousness movement and the Black Arts movement. Also, explicitly experimental, BAG differed from the AACM in that it was deliberately interdisciplinary, moving beyond just music (Looker 2004). Both of these groups were social and artistic, political and experimental. Their influence on jazz music is still quite powerful; many of their members remain prominent and influential musicians on the contemporary scene. While these are the most famous and the organisations whose influence on the music scene is most enduring, there were other similar organisations that formed in Detroit, New York, Baltimore, and elsewhere.

A final note must be made to the aggregations of jazz musicians who have formed literal communities. More than the brotherhood (and sadly, only to a lesser degree "the sisterhood" in many cases), these communities form around ideas that go beyond attracting journeymen into the fold. Chief among these is the UGMAA, the Union of God's Musicians and Artists Ascension. UGMAA was a collective of African American jazz musicians formed by Horace Tapscott in the late 1960s. It was part of his work with the Pan Afrikan Peoples Arkestra. UGMAA differed from other musician collectives in that it was explicitly community centred and politically conscious. One did not have to be a proven brilliant musician to join. UGMAA played free concerts for the community in Leimert Park and aligned itself with the Black Panthers' free breakfast efforts and conducted a music school (Tapscott 2001, Isoardi 2007). The focus on community was first modelled by Tapscott himself. Instead of continuing his career with Lionel Hampton as a trombonist, he decided to stay home in Los Angeles rather than moving to New York and following the usual trajectory of musicians with ambitions of having national followings and significance. He stayed in Los Angeles nurturing the black community through music and social programs. Unlike musician communities such as Sun Ra's Arkestra in Chicago during the 1950s and 1960s, and later basing them in Philadelphia up until his death (with a sojourn to Harlem to collaborate with Amiri Baraka at the beginning of the Black Arts Movement), Tapscott's pedagogy was in a way more democratic. Sun Ra remained the leader in all ways, composing the music, rehearsing the band, and building the musical praxis of the Arkestra. Tapscott allowed the members to compose and lead and even record, often before they themselves felt ready. What resulted was a unique focus on the community's work toward the national black aesthetic. It is so interesting that UGMAA, despite its differing approach to professionalism, also ended up producing musicians of national importance.

The author joined with composer/saxophonist/activist Fred Ho in the 2000 s to form the Scientific Soul Sessions (Ho 2009). Scientific Soul was a 
revolutionary group that engaged in political study and organisation coupled with artistic expression and performance. The scientific aspect was the approach to political organising and the soul part was the insurance that the political endeavours would be governed by the insights inherent in the music and other cultural expressions. It was a direct continuation of the contributions made by the earlier groups discussed here with a desire to remain relevant, politically and artistically, in the twenty-first century.

Indeed, the jazz imaginary remains governed by the need for and the ideas of freedom as imagined historically by African Americans. Whether in the music itself, or in literature or other arts, or explicitly in political and social terms, the jazz imaginary is a fertile terrain for freedom.

\section{Notes}

1 From the Quarantine Tapes Podcast with Paul Holdengrüber, November 11, 2020.

2 Ibid.

3 See Washington 2004, Monson 2007, Litweiler 1984, Moten 2003.

4 The film was actually prescient. The film makes the claim that the spirit of jazz was still alive but that the art form was dead. It was dead because the endless cycles of improvising over chord changes was a straightjacket that killed the freedom of expression and limited the formal possibilities available. In this very year, Miles Davis released his epochal recording Kind of Blue in which modal jazz is explored and Ornette Coleman threw down the gauntlet with respect to chord change playing and the need to transcend it with Coleman, Ornette. 1959 The Shape of Jazz to Come. Atlantic Records, 1317.

The Shape of Jazz to Come.

5 See Kubik, pp. xvii, 329-384.

6 Among my favourite discussions of this relationship between jazz and poetry are the various discussions in Kimberly Benston's Performing Blackness: Enactments of African American Modernism, especially his meditations on the Coltrane Poem. While Benston's interests are in the Black Arts oeuvre, Brent Hayes Edwards' Epistrophies: Jazz and the Literary Imagination offers insightful analyses of the poetics of more outré figures, Mary Lou Williams and Henry Threadgill, and the magisterial Nathaniel Mackey. Edwards is primarily interested in the literary tradition as evidenced by writings my musicians themselves, and he begins with the canonical fathers Louis Armstrong and Duke Ellington. His inclusion of Mary Lou Williams, Sun Ra, and Threadgill reveals that he is interested in the breadth and longevity of this literary tradition.

7 "The Screamers" by Amiri Baraka is anthologised in Baraka, Amiri. 2000. The Fiction of LeRoi Jones/Amiri Baraka. Chicago: Lawrnce Hill.

8 This figure of Soul music as representing the liberating force found in young people is also placed in Langa's novel, Texture of Shadows. In Mongane Serote's master jazz novel, To Every Birth Its Blood, we see again the trope of hopefulness (and action) of the youth being inspired by Soul music.

9 Coltrane, John. 1965 A Love Supreme. Impulse! 1764903.

10 Brent Hayes Edwards' (2017) Epistrophies: Jazz and the Literary Imagination is a tour de force study that offers a very insightful and nuanced discussion around the writings of Louis Armstrong. In Epistrophies Edwards considers Jazz's literary imagination through the writings of canonical musicians including founding 
fathers Ellington and Armstrong and founding mother Mary Lou Williams. He even discusses the micro-poetics of song titles analysing the work of Henry Threadgill.

11 It is beyond the scope of this chapter to consider why these writers accept American nationalism while excoriating the proponents of black nationalism. It is curious, however, that the political conservatism of this wing of black criticism would emerge triumphant just as jazz reaches mainstream importance.

\section{Works cited}

Baraka, Amiri. 2000 The Fiction of Leroi Jones/Amiri Baraka. Chicago: Lawrence Hill.

Bechet, Sidney. 2002 [original 1960] Treat it Gentle: An Autobiography. Cambridge, MA: Da Capo.

Benston, Kimberly. 2000 Performing Blackness: Enactments of African American Modernism. London: Routledge.

Bland, Edward O. 1959 The Cry of Jazz. KHTB Productions.

Coleman, Ornette. 1959 The Shape of Jazz to Come. Atlantic Records, 1317.

Coltrane, John. 1965 A Love Supreme. Impulse! 1764903.

Dunbar, Paul Laurence. 1903 When Malindy Sings. New York: Dodd, Mead \& Company.

Edwards, Brent Hayes. 2017 Epistrophies: Jazz and the Literary Imagination. Cambridge: Harvard University Press.

Ellison, Ralph. 1962 “On Bird, Bird-Watching, and Jazz: Bird: The Legend of Charlie Parker, by Robert George Reisner.” in Saturday Review. July 28, 1962, pp. 47-49.

Emerson, Ralph Waldo. 1837 “The American Scholar". Speech delivered at Harvard University, Phi Beta Kappa Society.

Hartman, Saidiya V. 1997 Scenes of Subjection: Terror, Slavery and Self-making in Nineteenth-Century America. New York, Oxford: Oxford University Press.

Ho, Fred. 2009 Wicked Theory, Naked Practice. Minneapolis: University of Minnesota Press.

Holdengrüber, Paul. n.d. Quarantine Tapes Podcast. November 11, 2020.

Isoardi, Steve. 2006 The Dark Tree: Jazz and the Community Arts in Los Angeles. Berkeley: University of California Press.

Jaji, Tsitsi Ella. 2014 Africa in Stereo: Modernism, Music and Pan-African Solidarity. New York: Oxford University Press.

Jones, Gayl. 1991 Liberating Voices: Oral Tradition in African American Literature. Cambridge: Harvard University Press.

Jones, LeRoi. 1963 Blues People: Negro Music in White America. New York: William Morrow.

Khumalo, Fred. 2006 Bitches' Brew. Auckland Park: Jacana Press. 2019 The Longest March. Cape Town: Umuzi.

Kubik, Gerhard. 2017 Jazz Transatlantic: The African Undercurrent in TwentiethCentury Jazz Culture. Jackson: University Press of Mississippi.

Lamar, Kendrick. 2015 "For Free?" in Lamar, To Pimp a Butterfly. Interscope.

Langa, Mandla. 1989 A Rainbow on the Paper Sky. London: Kliptown Books.

___ 2000 The Memory of Stones. London: Lynne Rienner.

Levine, Lawrence. 1977 Black Culture and Black Consciousness: Afro-American Folk Thought from Slavery to Freedom. New York: Oxford University Press. 
Lewis, George. 2007 A Power Stronger than Itself: The AACM and American Experimental Music. Chicago: University of Chicago Press.

Litweiler, John. 1984 The Freedom Principle: Jazz after 1958. New York: William Morrow \& Co.

Looker, Benjamin. 2004 Point from which Creation begins: The Black Artist Group of St. Louis. Chicago: University of Chicago Press.

Lott, Eric. 1988 “Double V, Double Time: Bebop's Politics of Style," in Callaloo No. 36, pp. 597-605.

Mackey, Nathaniel. 1997 Bedouin Hornbook. Los Angeles: Sun and Moon Press.

___ 2008 Bass Cathedral. New York: New Directions.

. 2017 Late Arcade. New York: New Directions.

Mingus, Charles. 1971 Beneath the Underdog: His World as Composed by Mingus. New York: Vintage Books.

Mohlele, Nthikeng. 2013 Small Things. Scottsville: University of KwaZulu-Natal Press.

____ 2019 Illumination. Johannesburg: Picador.

Monson, Ingrid. 2007 Freedom Sounds: Civil Rights Call Out to Jazz and Africa. New York: Oxford University Press.

Moten, Fred. 2003 In the Break: The Aesthetics of the Black Radical Tradition. Minneapolis, London: University of Minnesota Press.

Ngozi, Winston Mankunku. 1968 Yakhal' Inkomo. World Record Co. ORL 6022.

Nkosi, Lewis. 1966 "Jazz in Exile," Transition 5 (24), pp. 34-37.

O’Meally, Robert. 1998 The Jazz Cadence of American Culture. New York: Columbia University Press.

O’Meally, Robert, Brent Edwards, Farah Jasmine Griffin, eds. 2004 Uptown Conversations: The New Jazz Studies. New York: Columbia University Press.

Petry, Ann. 1947 "Solo on the Drums". The Magazine of the Year. New York: Associated Magazine, pp. 105-110.

Rollins, Sonny. 1958 Freedom Suite. Riverside.

Serote, Mongane Wally. 1978 To Every Birth Its Blood. Johannesburg: Raven Press.

Snead, James. 1998 "Repetition as a Figure of Black Culture” in O'Meally (1998), pp. $62-81$.

Soul, Jazzmen. 1968 Inhlupeko (Distress). Port Elizabeth: City Special, CYL 1000.

Tapscott, Horace. 2001 Songs of the Unsung: The musical and Social Journey of Horace Tapscott. Durham: Duke University Press.

Washington, Salim. 2004 "All the Things You Could Be by Now: Charles Mingus Presents Charles Mingus and the Limits of Avant Garde Jazz” in O’Meally (2004). . 2015 "Silence, Music, Revolution Jazz as Narrative Agent in Mongane Wally Serote's To Every Birth Its Blood, in Journal of Literary Studies, special issue edited by Thlalo Radithlalo.

2016 "Fingering the Jagged Grain: The Jazz/Blues/Mbaqanga Impulse of Mandla Langa". The World of Music (New Series) Number 5 (2). Berlin.

Wright, Richard. 1940 Native Son. New York: Harper \& Brothers. 


\title{
10 Empowering communities through liberalisation of airwaves in Ghana
}

\author{
Africanus L. Diedong
}

\section{Introduction}

Ghana currently enjoys a vibrant media environment, which can be attributed to a large extent to her boldness and foresight to embrace the wave of democratisation, which blew across the West Africa sub-region in the 1990s (see Huttington 1992). The experiment in democratisation was initiated against a context of a long history of emasculation of the media in Ghana in the pre- and post-independent era. The pluralist media regime being witnessed today in Ghana can be described as a dividend of liberalisation, which was a residual effect of the democratisation process, which birthed more independent press options (Kasoma and Pitts 2018: 98). The significance of a free press in nurturing and sustaining the tenets of democracy - human rights, giving voice to voiceless, rule of law and a relatively autonomous and dynamic civil society cannot be over-emphasised. Scholars such as Kasoma (2000: 40) assert: 'My view is that the press for as long as it is relatively free and independent can, in some measure, help to democratize society'.

Notwithstanding efforts to ensure that the media landscape, particularly the broadcasting sector, is truly liberalised by factoring in community interests and needs in an inclusive and responsive manner, it is problematic how such a process is being successfully implemented in Africa. The colonial legacy of operating a media system, which is closely tied to the apron strings of the government of the day still lingers on. The rampant broadcast license revocations after the August 2016 elections and press shutdowns in Zambia are well documented (Gaffey 2016). The picture of how control and power over radio stations is being exercised is neither seen in binary terms of colonialists verses subjugated blacks nor is it directly seen as "castle" (the seat of government in Ghana) versus the autonomy of editors/newsroom at Stateowned radio stations; rather, it is evidenced by individuals and commercial entities with capitalist interests and neo-colonialist philosophies whose zeal in broadcasting is at variance with core principles of community radio. If the current mode of operating radio broadcasting is not as progressive and beneficial as expected though its ownership is right in the hands of local 
operators, perhaps what a psychiatrist and a writer, Frantz Fanon, said of the African after gaining independence from colonial governors is instructive: 'African governing elites are black people with white masks'.

The symbiotic relationship that exists between the media and the government is an important feature of modern democratic practice. The nature of governance, especially good governance, requires broad support base of the citizens of a country. It implies that issues of human and sustainable development ought to be topical in discourses between government and citizens. Participation of citizenry in public discourses puts a lot of value on information, which members of a given society can access in an unfettered manner to make informed decisions about their socio-economic and political situations. The reality, however, in the current broadcast regime is that because of organisational structural challenges, implementation of principles of transparency and inclusiveness is problematic. Consequently, the interests of sections of society, most especially those of the marginalised and minority, seem subjugated to partisan political interests. The inability of post-independent rulers to enact legislation and transparent codified regulations might have accounted for this (see Karikari 2020: 48).

Despite the ubiquitous nature of new media, in Africa it is a fact that broad swathe of populations in rural and deprived communities can hardly access new media for information in an era whereby the terrain of interaction between government and citizen has gone beyond traditional spaces to encompass virtual communities in unprecedented ways (see Carpentier 2001). Across Africa radio remains the most preferred channel for most communities, especially the rural ones. Maractho (2018: 80) notes that the accessibility and affordability of radio as well as its capacity to be shared endear it to many. It is perhaps in response to the appeal of radio that with the blessings of the guarantees of the fourth republican constitution of Ghana, a flood gate seems opened for plethora of radio stations to operate. It is assumed that given the fight for press freedom in Africa, proponents of a liberalised media regime in Africa would celebrate the current development in Ghana and parts of Africa. The presence of radio in the media landscape is positive and indicative of hope that a lot can be tapped from it in pursuit of Africa's development agenda. However, this development should not make people remain in the comfort of their voices, while appearing oblivious of how radio ought to transition itself to become a well-integrated medium of communication capable of combining varied discourses on communities' development issues.

Amidst the cacophony of voices aired on numerous radio stations in Ghana, it is a big question whose voices are dominating airtime, and what is being lost and the implications thereof in terms of community development. It is a point of scholarly curiosity to ask: How deep is community participation in radio in the euphoria surrounding the liberalisation of airwaves in Ghana in the 1990s and its implications for facilitating and strengthening sustainable development? There is dearth of literature in this area of 
research. This therefore makes a study that examines how community participation happens in radio in a liberalised media regime since 1992 compelling. This chapter comprises six sections. The first section focuses on context of deregulating broadcast environment in Ghana. The second section deals with importance of communicating with communities in Ghana. The third section is about empowering communities to articulate their visions for development. The fourth and fifth sections deal with opening up more spaces for communication in communities in evolving digital culture in Ghana and paradox of the paradigm shift of radio broadcasting for communities. The last section is the chapter's conclusion.

\section{Context of deregulating broadcast environment in Ghana}

Before Ghana gained independence from Britain in 1957, the broadcast landscape was totally under the control of British colonial masters. An overriding reason that account for such a tight grip of the broadcast system was to ensure that power was in the right hands and effectively utilised to achieve the agenda of the colonial administrators. It is important to note that the idea of regulating the media during the pre- and post-independent era needs to be appreciated within the context of the media being seen by the State as an intrinsic part of the political power if not power by itself. Across Africa rules and regulations guiding the operations of radio stations predates the current status quo albeit its logic seems paradoxically informed by historical antecedents (see National Communications Authority Act, 2008, Act 769). The underlining aim of Empire Broadcasting, which might not have been explicitly expressed in policy documents, which informed the enactment of rules and regulations is captured in the Plymouth Report in 1936, a policy study of "Broadcasting Services in the Colonies," published in 1937:

This represented the combined thinking of the Colonial Office, the Crown Agents, the BBC, and an advisor on colonial education. The committee, under the chairmanship of Lord Plymouth, recognized the great indirect propaganda value to Britain of broadcasting to the colonies: "Regular daily contact with the Home Country (and at times with other parts of the Empire) and the repeated projection on the minds of listeners overseas of British culture and ideas, and all that this implies must exert a great influence. The effect of this in the long run is perhaps the more valuable, because it is neither direct nor deliberate".

(Great Britain 1937: 5)

The insight which can be drawn from this excerpt is that the power of media cannot be under-rated in the process of ruling and galvanising the support and empathy of citizens in national development. Therefore, over the years evidence of efforts marshalled in favour of organising, controlling and deploying such instruments of power to support national development process 
across Africa overtly or covertly informs various control mechanisms of broadcast systems in Ghana.

Ghana has had a long tradition of State ownership and control of the media, dating back to pre-independence times. From the introduction of radio in the Gold Coast in 1935 and television in 1965 till the airwaves were liberalised in 1996, radio and television were controlled by the colonial and then the post-colonial State. Though colonial and post-colonial rulers saw the media as a great tool for the education and enlightenment as well as a persuasive instrument to mobilise citizens for national development, they exerted degrees of controls over the content of radio broadcast. For example, the first post-colonial president of Ghana, Dr. Kwame Nkrumah, introduced censorship and repressive laws such as the Preventive Detention Act, which allowed him to lock up or detain anybody without trial for up to five years while the Newspaper Licensing Act made it impossible for anyone outside the government to operate a newspaper. After the collapse of Dr. Nkrumah's government, tight control over the media continued unabated under various military regimes ending with that of former president Flt-Ltd Jerry John Rawlings (1981-1992), whose regime is remembered for introducing "culture of silence" in Ghana (see Gadzekpo et al. 1996). Intellectuals such as Prof. Paul Ansah led the process with discourses in support of deregulating the media landscape in Ghana.

By the 1980s State monopoly of mass media was beginning to cave in, thanks to the wind of change blowing across Africa. Ansah (1985) argues that opening up the airwaves could stimulate development and create more jobs like it did in Asia and Central America. A study (Safo 1993) on the "Implications of Privatisation of Radio and Television" in Ghana found that $90 \%$ of a sample of 100 experts welcomed the idea of privatisation. The respondents who objected were mostly employees from the State-controlled Ghana Broadcasting Corporation, arising from their apprehension for competition. Despite the overwhelming support for the privatisation of broadcasting, the Provisional National Defense Council government was reluctant to loosen its grip on the electronic media until May 1994, when residents of Accra woke up to the sound of a pirate FM station called "Radio Eye". After 24 hours of operating, the security agencies shut down the station and arrested Dr. Charles Wereko Brobbey and his team of technicians. The confiscation sparked riots in Accra, ending the first attempt at breaking State monopoly over broadcasting. It was not until July 1995 that Joy FM was licensed to operate in Accra.

Notably at the time the 1992 Constitution was written, the emergence and growth of independent radio and television and the need for radio spectrum, a scarce public resource to be regulated in the public interest, appears not to have been fully considered as an essential aspect for a free and independent media. It was only after a test case by Radio Eye, which took to the airwaves without authorisation in 1994, that the need was accepted for radio frequencies to be assigned for independent use. In 1995 the Ghana 
Frequency Registration and Control Board (GFRCB) put out the first call for applicants to operate broadcasting services independent of Ghana Broadcasting Corporation. The first frequencies were assigned in July 1995 for ten commercial radio services to operate in Accra, Kumasi and SekondiTakoradi, though no community radio applications were accepted at that time. A further ten frequencies were assigned in May 1996 for rural areas including three CRSs services. The GFRCB was relinquished in 1996 by the National Communications Authority (NCA), which has continued to assign frequencies to private commercial broadcasting services.

As at the Fourth Quarter of 2018, the NCA has given frequency authorisations to 487 FM broadcasting stations in Ghana. Out of the total number of authorised FM broadcasting stations, 398 stations are currently operational (NCA 2018). Whereas the wide latitude of freedom to operate independent and CRSs was missing in the scheme of policies and regulations of the colonial broadcast system, the colonial masters nonetheless regarded broadcasting as a means for 'the enlightenment and education of the more backward section of the population and for their instruction in public health, agriculture, etc.' (Great Britain 1937: 4-5). According to Head (1979), this goal implied, of course, local production of local programs not simply relays of the BBC's Empire Service. With the coming of World War II, only two years after the Plymouth Report was issued, local programming for the indigenous population became not a matter of choice but an urgent necessity. "Enlightenment and education" took second place, however, to persuasion and propaganda.

Herein lies the dialectics in the content of community radio programming in Ghana, which seems more commercial and other interests driven rather than being community-oriented and truly participatory. It can be contested that this mode of operation is parallel to the motives and philosophy of editorials of colonial broadcast albeit under the cloak of constitutional mandate. Community radio broadcast sector needs to responsibly use the opportunity granted it under the current liberal regime to pursue community-driven news and social issues capable of making people gain greater self-consciousness and autonomy to define their developmental agenda collaboratively with stakeholders. Deregulation of the broadcasting sector should be valorised and prioritised more philosophically and practically around horizontal communication and giving of voice to the voiceless to enable communities realise their capabilities for human development rather than it being seen as a mere shift from a suppressed colonial space to a so-called pluralistic and liberalised media regime.

\section{Importance of communicating with communities in Ghana}

Fostering and sustaining approaches of communicating with communities is desirable to establish a strong civic democratic culture in Ghana. Communication is a life-wire that can bond people to plan, implement and evaluate programs and activities for the common good. Yet it is a big challenge, 
which is not insurmountable because Gro Brundtland, Prime Minister of Norway, and Chairperson of the World Commission on Environment and Development once noted that the only way we can work for a common cause, for common interest, is really through communication. Basically, it has to do with democracy, with participation, with the spreading of knowledge and insight and ability to take care of our future... The relevance of communication in society is appreciated by scholars. Eilers (1994: 12) notes that without communication no human person can live and no human society can exist. The capability of people to freely communicate with others in mutual sharing distinguishes any human from other societies and organisations. Scholars such as Babolin (2006) see communication as the characteristic process of sharing meaning through signs and symbols. Notably signs and symbols are unifying factors as exemplified in names and communal events such as festivals and funerals. The appropriate use of such signs and symbols gives a sense of value to help people to meaningfully articulate themselves through various forms of interaction in community.

Effective communication needs to bring people together in communion. When people find themselves in communion, community is born. This implies that a major cornerstone for community building is the recognition that people need to come together through communion and communication. Fraser and Estrada (2001:1) acknowledge this point thus: 'People live in a community by virtue of the things which they have in common; and communication is the way in which they come to possess things in common'. Most communities' communal ties are built around not only tangible assets such as land, forest resources and minerals, but more importantly they are deeply nested in time-honored values such as Godliness, respect, caring for others, peace, love, hospitality and gratitude (see Sarpong 1974), which need to be appreciated in current discourses about the importance of fostering patriotic virtues in citizens in support of development at community and national levels. These intangible values define how good or bad, peaceful or conflict-prone a community can be within a modern State.

In the light of these considerations, it is important high attention is placed on the means by which communication takes place in communities in emerging democratic countries. Despite the flourish of literature on how ICT is expanding and impacting lives of people in Ghana (Osborn 2012), it is yet to be seen how basic media can integrate well with modern means of social communication to contextually impact in meaningful ways the lives of people. In seeking peoples' appreciation and support to deliver interventions to improve the quality of their lives in for instance agriculture, education and health modern, communication models are often applied. According to Farhaan et al. (2008), mobile technology supports healthcare services in relation to accessibility, effectiveness and affordability. This is increasingly becoming a common practice because depending on certain conditions, people communicate with healthcare providers to seek solutions to their health challenges through the use of the Internet and mobile phones. 
However, it is a fact that access to ICT is still a problem across Africa. This implies that in development communication initiatives, the content and flow of information is still balanced in favour of those at the top - "the techno-elites". However, given the advantages of indigenous modes communication (IMC), one can imagine the exponential benefits, which can be derived through a mixed approach of blending IMC with modern models. The search for an integrated approach to communication in support of development in communities is far from being realised in Ghana. In a study on maternal health, Bagah et al. (2018: 98) reported that majority of the respondents supported the idea of integrating maternal health education strategies with local approaches that could improve maternal health education and information delivery. Be it in rural or urban settings, the dynamics of communication brings about opportunities, challenges and prospects. Barker (2007) elaborates on the main features of this changing communication and indicated that a core element within this emerging practice is to focus on an integrated, well-planned and practical implementable communication approach based on the theoretical underpinnings of development communication. Another, missing link is the unavailability of development communication practitioners in relevant sectors - education, health and agricultural to effectively implement development communication strategies, especially in deprived communities. Mersham et al. (1995: 52) have noted that it is essential that successful communication with communities be approached within a purposeful and interactional framework. Such a framework which ranges from songs and drama to radio programs, Internet and social media requires forms of participation, which privileges community inputs in diverse channels in well-planned, strategic and practical ways.

\section{Empowering communities to articulate their visions for development}

People naturally communicate because it is instinctual and leads to relationship and to community. Its basic axioms are participation and empowerment. According to Srampickal (2009: 21), participation happens through listening, sharing, debating, challenging and deepening all that has been learned. In the second level, it goes on to share power and make the other partakers of power. Delegating, decentralisation and subsidiarity are elements of participation whereby one is ready to make the other share the very same power that one wants to concentrate on oneself. In Ghana liberalisation of the airwaves has paved the way for communities to experience to a certain degree the power of community radio broadcasting and its ability for social transformation.

The mission of a community radio is to engender communities to take active interest in processes that bring improvement in the quality of life of communities. Vertical model of communication which places a lot of emphasis on professionalism is gradually opening up to embrace a dialogical 
and communitarian model, which can blend with democratic ethos. As human beings we use communicative ability first to establish human contacts and because of this, we are able to share meanings through common signs and symbols. It is in this connection theoretically, the adoption of a democratic-participant approach to the operation of community radio cannot be seen as costly and time-consuming, but can be seen as a necessary process of stimulating communicative action in favour of community development goals. One fundamental principle that underscores and guides community radio movement in Ghana and elsewhere is that communication is too important to be left to only professionals (see Roelofse 1996: 59-60).

The challenge in Ghana is how to practically enable people have voices in the growing number of CRSs across the country. Today, the vision of pioneer community radio such as Radio Progress in Wa, Ada FM and Peace FM in Winneba, which championed the cause of enabling communities to wake up and mobilise resources for community development, is yet to be fully realised. Until the logic and underlining principle of ensuring that the planning, designing, and implementation of programs are closely associated with community development goals and interests not much can be achieved in the liberalised space in which community radio operate. Though in scholarly discourses there is a growing conviction that community-based communication may be the most important communication process in social development, in practice much more needs to be done to achieve such a goal (Melkote and Steeeves 2001; Asuman and Diedong 2019).

Given the complexities of modern means of communication, particularly in rural communities, African scholars such as Semujju (2014: 206) propose basic media as a solution to solve community participation problems. Such media try to cut-off the bottlenecks of development communication like poverty that may block the communication process. It is claimed that these media appeal to solutions that are realistic for a given poor community. Discourses in support of pro-poor media systems are not idealistic; rather, they align with the concept of decentralising governance systems to the grassroots as a necessary off-shoot of the wave of democratisation which swept across Africa in the 1990s (MFWA 2015).

\section{Opening up more spaces for communication in communities in evolving digital culture in Ghana}

It is over three decades since Boafo (1988) wrote a compelling paper on the need to search for and implement strategies and mechanisms to democratise systems in African countries, create opportunities for mass participation in the national communication process and thereby establish a new internal communication order. Boafo's call has become even more pertinent today in Ghana because of the growing influence of ICT in the socio-cultural, political and economic development of countries. White (2009: 246; see Pieterse 2010) notes optimistically that technology in itself is more divisible and 
empowering through conscious participatory methodology; the new media facilitate more horizontal, farmer-to-farmer communication, strengthen the value of indigenous knowledge and lessen dependency on the vertical, extension model of communication; the new media strengthens community communication. Community radio benefits from new technologies. But inexpensive video and $\mathrm{CD}$ technology enables communities to produce their own media and exchange with other communities.

However in reality, many communities in Ghana are still far from experiencing profitable use of ICT as alluded to by advocates of the role of ICT in development process because of a host of factors. According to pessimists of the ICT in development (see Plange 1993), these factors include the dangers and pitfalls of the new communication technologies, such as the marketing of pornographic products on the Internet, the perpetration of organised corporate crimes and the likelihood that they may widen the existing gap between the information rich and information poor. In his critique of the technologically deterministic approaches that emphasise connectivity, technology transfer and training, Nyamnjoh (1996) has called for a socioanthropological approach to the development of ICTs that would allow Africa to regulate, adapt and innovate ICT to its own needs and priorities for sustainable development.

The essential point in these debates is to avoid being mired in binary opposition stances of viewing ICT as good or bad. Rather there is the need for some pertinent questions to be asked as ICT continue to evolve and influence the lives of people at community, national and international levels. There is a strong drive by governments in Africa to expand ICT facilities to particularly rural communities. In Ghana, under the auspices of the Ghana Investment Fund for Electronic Communications a smart community project is being initiated. The project is being piloted in communities such as Asumura, Asankragwa, Goaso and Berekum. The aim of this project is to provide an affordable/free WiFi service to unserved or underserved communities across the country. The Smart Community is a base/access point for providing all other broadband services to those communities including but not limited to Digital for Inclusion (D4I) and Cloud Content.

In initiating such projects it is important to ask: As the new communication technologies are related to power structures, how are they being appropriated in the different cultural settings? Are there mechanisms to respond to the concerns about the use of new technologies of communication? While answers are still being sought, a plausible way out for ensuring a measure of empowerment for communities' participation in development communication is through basic media. Basic media are 'community-accessible media that provide on-time information about people's basic needs and suggest immediate solutions' (Semujju 2013: 31). The idea of according importance to basic media is good, but this should not be done in isolation because in contemporary times the presence of the virtual community cannot be 
overlooked (see Carpentier 2001). Discussion about how basic media can be blended with modern means of communication such as community radio, Internet and social media platforms by relevant stakeholders such as the Ghana Community Radio Network and National Media Commission and Media Foundation of West Africa (MFWA) seems mute. The complexities, opportunities, contradictions and contestations of the deployment of ICTs and its implications on how people relate and communicate, especially in rural communities, are worth noting in the search for an equitable, inclusive and just means of communicating capable of facilitating sustainable development.

\section{Paradox of the paradigm shift of radio broadcasting for communities}

From Mexico to the USA through to the UK, Mali, South Africa and Ghana, community radio has gained a wide space to operate under varying degrees of statutory regulatory mechanisms to guarantee efficiency and effectiveness in the use of radio frequencies to support development communication (see Eryl and Tacchi 2001). Whereas during the colonial era the usefulness of radio in Ghana was seen in how they were mainly used by colonial governments as tools for propaganda and to promote their interests (Great Britain 1937), under current democratic arrangements in which it is argued that democratic governance is the best prerequisite for governance that serves the majority of the population (Sen 1999), community radio is performing critical roles of enabling people in communities to participate in discussing broad range of issues that affect their lives.

Theoretically, there is a shift from the authoritarian press regimes, which characterised colonial and post-colonial governments' control of broadcasting systems to a liberalised democratic-participant model which seeks to empower people to have a stake in the growth and development of their communities. According to Stephen (2012: 137-138), community radio performs important roles in communication, community building and promoting local cultural forms. These roles range from providing a call-in forum where migrants in the USA can communicate with relatives to broadcasting local dance or music performances, as well as programs discussing health, education and human rights. Therefore, it is not surprising that Africa is witnessing an increasing trend of community presence. Two countries alone, South Africa and Mali, which have made a determined effort to establish community radio, account for nearly half of the total number of community radio stations in Africa (Alumuku 2006: 158). In Ghana as regards programming, evidence indicates that community radio is yet to convincingly demonstrate real community participation in community-based programming and direct involvement in management of community radio, which is key to defining communication in "community" (Diedong and Naaikuur 2015). 
It is important to emphasise that, in general, the descriptor community differentiates a radio station from its commercial and public (i.e., State) counterparts. The defining, though perhaps vague, property that enjoins all CRSs is a local, participatory approach to programming and governance (Doyle 2012). The conceptual importance of community radio is that it is a mode for expressing local perspectives that for various reasons are unrepresented in other media. Indeed, bringing the community into the process of developing democratically based media requires that community radio adopts/adapts five main steps Hochheimer proposed (Hochheimer 1999: 247):

- Identifying the participants

- Defining the issue or problem

- The problem-solving process and resource identification

- Setting goals and objectives including assigning roles and responsibilities

- Design of action plan and community feedback

Though the process seems laborious and demands a lot of resources $-\mathrm{a}$ fact noted by scholars - it is such programs that the audiences and other development partners tend to appreciate and co-sponsor because in the long run they can positively impact the lives of people (see Alumuku: 177-184). The current program format of CRSs in Ghana and parts of Africa (see Semujju 2014: 207; Amoah 2016: 32) seems out of reach of community members, though as per the principles of community radio community members are the key drivers of their operations.

If the modest successes community radio has chalked over the past two decades in the liberalised space (Diedong and Naaikuur 2012; Mohammed and Alhassan 2017) are allowed to be subtly controlled by commercial and other interests, thereby displacing communities of their capability to raise relevant debates and discussions on the matters affecting the lives of the majority within their audiences, it can be asserted that the effective performance of community radio is gradually compromised on the altar of neo-colonialist imperatives. In terms of exemplifying features of neocolonialism (see Domatob 1988), radio stations appear to mainly operate with commercial and partisan motives in order to satisfy the interests of their owners, whose hidden hand controls them. This has triggered media industry and rights advocacy civil society organisations' groups to form the Coalition for the Transparency of the Airwaves as a form of platform for critical discourse and a move towards decolonising political communication on airwaves.

Evidence of use of community as an instrument to achieve controversial political interests is being manifested in Ghana. On 20 April 2020, the NCA informed the general public about the illegal activities of some persons involved in the operations of Radio Tongu 92.1 MHz and its decision to shut down the station. The NCA noted that as a community radio the 
Authority will continue to engage the leadership of the South Tongu Community/TCMN and the District Security Council to find a lasting solution to the impasse, while the law takes its course with regard to the individuals arrested (NCA 2020). Given the current profile of the content of radio broadcast, the nature of management of community radio and the manner of interaction between community radio and their audiences, semblance of neo-colonialist tendencies is subtly at play. This sharply contradicts the raison d'être for the establishment of CRSs and the theoretical foundation of their operations and requires in-depth research to examine the incongruity between the NCA policy stipulations on the ownership and operations of community radio and the reality on the ground.

\section{Concluding remarks}

A question was posed about the depth of community participation in radio in the euphoria surrounding the liberalisation of airwaves in Ghana in the 1990s and its implications for facilitating and strengthening sustainable development. The conclusion that can be drawn is that community participation in the liberalised space, which began with community radio taking initiatives to involve their audiences on development programming, has evolved and is becoming sophisticated with the growth of ICT. This has implications regarding who is really empowered through the emerging networked communication systems against the backdrop of poverty, human and resource constraints. These challenges make it difficult for communities to actually participate in sustainable ways in the opportunities afforded by the liberalisation of airwaves in Ghana.

The issue of power play in community radio may not be that apparent to community members since it appears that their voices are mostly heard during phone-in and panel discussion programs. To some extent, technology is affording a greater majority of Ghanaians in rural communities to participate in such discourses. However, as van Dijk (2006) posits, the advantages obtained from using technologies depend on how well organised the people and groups are, and the resources they can access and control.

Real empowerment of communities is possible when there is integration between modern means of communication and basic media. This requires the existence of functional Radio Listener Groups (RLGs) - currently non-existent - in communities and the willingness of the Ghana Community Radio Network and their media partners to establish meaningful linkages with various communities through RLGs to ensure that identified gaps and weaknesses militating against community participation in community radio are redressed. This would give practical significance to affirmations by development communication scholars that communication needs to facilitate development initiatives through participatory approaches. 


\section{References}

Alumuku, P. (2006). Community Radio for Development: The World and Africa. Nairobi: St. Paul Publications.

Amoah, R. (2016). The Media and Politics in Ghana's Fourth Republic. Unpublished MPhil Thesis presented to the University of Ghana in partial fulfillment of the requirement for the award of MPhil degree in Political Science. Available at: http://ugspace.ug.edu.gh/

Ansah, P. (1985). GBC Golden Jubilee Lectures. Accra: Ghana Publishing Corporation. P21.

Asuman, M. \& Diedong, A. (2019). Multiplicity of Voices in Community Development through Radio in Fanteakwa District, Ghana. Ghana Journal of Development Studies, Vol. 16 (2), pp. 178-198.

Babolin, S. (2006). Semiotics in the Media. In L. Baugh, G. Mazza and J. Srampickal (Eds.), Cross Connections (pp. 241-248). Rome: Editrice Pontificia Universita Gregoriana.

Bagah, J., Diedong, A. \& Achana, G. (2019). Maternal Health Education and Promotion: Perceptions from Wa Municipality of Upper West Region, Ghana. Journal of Communications, Media \& Society, Vol. 6 (1), pp. 85-102.

Barker, R. (2007). Communication with Communities: A South African Experience. Communication, Vol. 27 (1), pp. 3-14. DOI: 10.1080/02500160108537919.

Boafo, K. (1988). Democratizing Media Systems in African Societies: The Case of Ghana. Gazette, Vol. 41(1), pp. 37-5. DOI: 10.1177/001654928804100104

Carpentier, N. (2001). Managing Audience Participation: The Construction of Participation in an Audience Discussion Programme. The European Journal of Communication, Vol. 16(2), pp. 209-232.

Diedong, A. \& Naaikuur, L. (2012). Ghana's Experience in Participatory Community Radio Broadcasting. Global Media Journal, African Edition, Vol. 6(2), pp. 123-147.

. (2015). Who is the "Community" in Community Radio? A Case Study of Radio Progress in the Upper West Region, Ghana. Ghana Studies, Vol. 18, pp. 68-89.

Domatob, K. (1988). Sub-Saharan's Media and Neo-colonialism. Africa Media Review, Vol. 3(1), pp. 149-174.

Doyle, B. (2012). Low-Power Community Radio in the US: The Beginnings, the First 10 Years and Future Prospects. In Community Radio in the Twenty-First Century, edited by J. Gordon. New York: Peter Lang Publishing.

Eilers, F. (2002). Communicating in Community: An Introduction to Social Communication (3rd Ed.). Lagos: Divine Word Publications.

Eryl, P. \& Tacchi, J. (2001). Community Radio in Global Context: A Comparative Analysis in Six Countries. Sheffield, UK: Community Media Association.

Farhaan, M., Norris, T. \& Stockdale, R. (2008). Mobile Technologies and the Holistic Management of Chronic Diseases. Health Informatics Journal. DOI: $10.1177 / 460458208096559$.

Fraser, C. \& Estrada, S. (2001). Community Radio Handbook. Paris: UNESCO.

Gadzekpo, A., Karikari, K. \& Yankah, K. (Eds.) (1996). Going to Town: The Writing of P. A. V. Ansah. Accra: Assemblies of God Literature Centre Ltd.

Gaffey, C. (2016, August 23). Zambia: Three Broadcasters Shutdown as Opposition Alleges Media Crackdown. Newsweek. Available at http://www.newsweek. com/zambia-three-independent-broadcasters-shut-down-opposition-allegesmedia-492764. 
Great Britain. (1937). Colonial Office. Interim Report of Broadcasting Committee ("Plymouth Report"). Colonial No. 139. London.

Head, S. (1979). British Colonial Broadcasting Policies: The Case of the Gold Coast. African Studies Review, Vol. 22(2), pp. 39-47.

Hochheimer, J. (1999). Planning Community Radio as Participatory Communication. In S. White (Ed.), The Art of Facilitating Participation (pp. 244-258). London: Sage Publications.

Huttington, S. (1992). The Third Wave. Democratization in the Late Twentieth Century. Norman: University of Oklahoma Press.

Karikari, K. (2020). Broadcasting Pluralism: Pres Freedom and Democratic Governance, 25 Years after 'Radio Eye'. In K. Akpabli (Ed.), Plenty Talk Dey 4 Ghana (pp. 41-64). Accra: Anansesem Publications.

Kasoma, F. (2000). The Press and Multiparty Politics in Africa. Tampere. Finland: University of Tampere.

Kasoma, T. \& Pitts, G. (2018). Mapping Zambia's press freedom Trajectory: A Longitudinal Study Examining Parliamentarian's Perspectives of the Media. In B. Mutsvairo and B. Karem (Eds.), Perspectives on Political Communication in Africa (pp. 95-112). London: Palgrave Macmillan.

Maractho, C. (2018). Determinants of Participation in Political Communication in Uganda's Broadcast Media: Implications for Women. In B. Mutsvairo and B. Karem (Eds.), Perspectives on Political Communication in Africa. London: Palgrave Macmillan.

Melkote, S. \& Steeves, L. (2001). Communication for Development in the Third World: Theory and Practice for Empowerment. New Delhi: Sage Publications.

Mersham, M., Rensburg, S. \& Skinner, C. (1995). Public Relations, Development and Social Investment: A Southern Africa Perspective. Pretoria: J L van Schaik Publishers.

MFWA. (2015). Report: Radio, Powerful Local Governance Tool. https://www. ghanaweb.com/GhanaHomePage/NewsArchive/Report-Radio-powerful-localgovernance-tool-346523

Mohammed, F. \& Alhassan, A. (2017). Community Access and Participation in Community Radio Broadcast: Case of Radio Gaakii in Northeastern Ghana. Journal of Development and Communication Studies, Vol. 5(2). DOI: 10.4314/jdcs.v5i2.6.

NCA. (2008). National Communications Authority Act, 2008, Act 769. . (2018). Authorized VHF-FM Radio Stations as at Fourth Quarter of 2018. https://www.nca.org.gh/industry-data-2/authorisations-2/fm-authorisation-2/

. (2020). Press Release: Radio Tongu in Sogakope Shutdown for Operating without Vaild Authorisation.

Nyamnjoh, F. (1996). Africa and the Information Superhighway: Silent Majorities in Search of a Footpath. Africa Media Review, Vol. 10(2), pp. 1-21.

Osborn, Q. (2012). The Growth and Usage of Internet in Ghana. Journal of Emerging Trends in Computing and Information Sciences, Vol. 3(9). Retrieved from http:// www.cisjournal.org

Pieterse, J. (2010). Digital Capitalism and Development: The Unbearable Lightness of ICT4D. In Phillip Kalantzis-Cope and Karim Gherab-Martín (Eds.), Emerging Digital Spaces in Contemporary Society (pp. 305-323). London: Palgrave Macmillan.

Plange, N. (1993). Video, TV and Fiji's Society: Fast-Forward into the Future or Pausing for a Closer Look. Pacific Islands Communication Journal, Vol. 16(1), pp. 73-77. 
Reolofse, J. (1996). Press Theories. In L.M. Oosthuizen (Ed.), Introduction to Communication. Course Book 5, Journalism, Press and Radio Studies (pp. 59-60). Cape Town: Juta.

Safo, A. (1993). Implications of Privatization of Radio and Television in Ghana. Unpublished Dissertation Submitted to Ghana Institute of Journalism for the Award of Diploma in Journalism.

Sarpong, P. (1974). Ghana in Retrospect: Some Aspects of Ghanaian Culture. Tema: Ghana Publishing Corporation.

Semujju, B. (2013). ICT an Engine for Community Participation: An Assessment of Uganda's Community Media. International Journal of Information Communication Technologies and Human Development, Vol. 5(1), pp. 20-36.

. (2014). Participatory Media for Non-participatory Community: Western Media for Southern Communities. The International Communication Gazette, Vol. 76(2), pp. 197-208.

Sen, A. (1999). Democracy as a Universal Value. Journal of Democracy, Vol. 10(3), pp. 3-17.

Srampickal, J. (2009). Communications can Renew the Church. Kochi, Kerala: Karunikan Books.

Stephen, L. (2012). Community and Indigenous Radio in Oaxaca. Testimony and Participatory Democracy. In L. Bessire and D. Fisher (Eds.), Radio Fields (pp. 124-141). Published by Manhattan: NYU Press.

Van Dijk, J. (2006). The Network Society (2nd Ed.). London: Sage.

White, R. (2009). Research on Communication for Development in Africa: Current Debates. African Communication Research, Vol. 2(1), pp. 203-252. 


\title{
11 In the realm of uncertainty Kenya's Ghetto Radio as politicised space
}

\author{
Wilson Ugangu
}

\section{Introduction}

In the period starting from the early to the mid-1990s, following the fall of the Berlin Wall, and the subsequent global wind of transformational change that brought democracy in its wake, Kenya's media and political landscape greatly changed - from state monopoly and domination to a vibrant plural space. A hitherto, patrimonial and autocratic state gave way to a nascent multiparty and socially diverse state. The historian, Hornsby (2012), has ably captured the events - internal and external of this period which impacted the Kenyan state leading to intense internal questioning of the power and legitimacy of the authoritarian one party state, while at the same legitimating divergent political voices. In this moment, the seed of economic, social and political change was planted. The communications environment, previously dominated by the state, was gradually freed as new private commercial players entered the scene.

Subsequently, in the two decades that followed, Kenya's media landscape has expanded, and transformed into one of the most vibrant in Africa (see also, Ismail \& Dean, 2008). The radio sector has seen phenomenal growth with private local language FM radio stations mushrooming across the country. In the past, the dominant languages of Kenya's establishment media were English and Kiswahili. The growth of the sector has opened up a market niche that is primarily based on local languages. More significant, however, is the power that this has brought to communities and social groups that could not get easy access to national information flows through the state broadcaster on the basis of language. What has happened is a keen to the low-power radio revolution - also known as media democracy, in the United States of America (USA) that brought non-mainstream voices into the broader national communication agenda (Dunber-Hester, 2014).

Ogolla (2010) contends that general disillusionment with mainstream media that mostly broadcast in English and Kiswahili (the two main national languages) provided timely impetus for the rise and growth of local language FM radio in Kenya during the first decade of the new millennium. The new model of urban-based FM radio that became popular in the mid-to-late 
1990s was mostly apolitical and tended to take a more globalist entertainment orientation in their programming. In a sense, this emerging model of FM radio was alienating, especially for certain groups within the Kenyan society that had traditionally felt left out during the age of dominant topdown and heavily state-dominated radio since independence. The general ideological thinking that informed mainstream media's functioning was the state's agenda for perpetual control of the masses by way of controlling information flows. Media were therefore generally coerced toward the state's development agenda.

The private owners of media who ventured into local language FM radio did not anticipate the social, cultural and political impact that these new ventures were going to have on the Kenyan society. They were mostly just shrewd business men and women breaking into virgin territory. The 2007 disputed general elections and the aftermath of violence saw local language feature prominently in national debate. Most observers, as the BBC Report (2008) shows, were obviously intrigued and confused by the political mobilisation potential of local language radio during this period. Subsequent discussions, including an expert report on that year's election by an Independent Review Commission (IREC) led by retired South African judge Johan Kriegler, provided useful hints showing local language radio assuming a more central role in grassroots political discourse across the country.

Historically, the dominance of English and Kiswahili as the languages of mainstream media in the country has, on the whole, had an alienating effect on certain social groups within the country. According to Ogolla (2010), the use of these languages by the country's media has always been in keeping with the state's policy of a unified country/Kenyan society. However, this dominant ideology of unity obfuscates the reality of the multiple shades of identities, and political and cultural differences that manifest within the Kenyan society. The emergence of local language radio seemed to provide the space where non-mainstream views would be unleashed - sometimes in the most creative and novel ways.

\section{A multi-perspectival view}

Generally, as noted in the foregoing discussion, the media, specifically the FM radio scene across the globe, has greatly transformed and expanded in the last two decades of the twenty-first century. As it innovates and continues to target diverse audience groups, the attendant cultural forms have and continue to engender complex richness, variety and novelty. They are also fluid and in a constant state of flux. The implication of this is that scholarship has to seek and adopt a different mix of theoretical perspectives and approaches to assist in making sense of this emerging and constantly changing reality.

Acknowledging the vastness and complexity of the terrain of contemporary culture, Kellner and Durham (2006) note the implication this has on 
the ensuing debate, especially given the maze of, and intensity of the theories and debates over media and culture. In this regard, one can only draw from some perspectives while leaving out others, and yet also acknowledging that one specific theory may not adequately assist in exploring today's changing media culture landscape. In this chapter, we have attempted a multi-perspectival approach - from where attempts are made to draw from the expansive literature on language and identity as well as the emerging discourse on postmodernism to problematise, and understand the complex reality of a media space that speaks to and for non-mainstream voices within the Kenyan urban society context.

\section{Ghetto radio 89.5 FM}

Ghetto radio 89.5 FM was set up in 2007. The mother company - Ghetto radio - also operates two news websites: Ghettoradio.co.ke and Thisafrica. me. Priding itself as the number one Sheng ${ }^{1}$ radio station in Nairobi, Ghetto radio $89.5 \mathrm{FM}$ was set up with the aim of providing what its website refers to as, "street credible news, views and entertainment by people from the urban slums and targeted at a broad public that stretches beyond the slums".

The main target however is Nairobi's slum dwelling, lower class and mostly unemployed youth. Ghetto FM's programming takes a unique character first, all the programs are done in the Sheng language. Program content mostly draws from the lived experiences, struggles and circumstances of ordinary people, living in the less privileged sections of Kenya's urban cities, and who feel removed from the centre of the country's social economic and political structure.

Ghetto radio's policy deliberately privileges the voices of those in the informal sector, and, as its website also declares, "The guy close to the streets". The radio station harnesses the creativity and bohemian inventiveness of young artists, the craziness, chaos, humour and vibrancy of modern Kenyan street life. In doing this, Ghetto radio has brought to the mainstream voices and lived experiences of urban slum life that two decades earlier could not have found expression in Kenya's establishment media. Background information on Ghetto FM's website says that the radio station's mission is to offer an insider's view of the craziness, chaos, ingenuity, absurdity, novelty, humour and vibrancy of urban street life, society and culture. In an interview with the DW TV Ghetto radio's founder, Mr. Jabel Julius Owino also known as Maji Maji says the radio was set up to explore the undocumented, non-mainstream narratives and lived experiences of urban slum life.

News and feature articles on Ghetto radio's website as well as the radio bulletins featuring various subjects, such as politics, social and economic events of national and even global magnitude, are always presented from the perspective of those close to the streets and in the country's informal economic sector. For instance, a recent story on the spread of the Corona virus (COVID-19) epidemic featuring on Ghetto radio's website foregrounds 
the plight of ordinary people in Nairobi's slums. This story is appropriately titled - expensive sanitisers, lack of water exposing slum residents to Corona. ${ }^{2}$ In the follow-up coverage of the spread of this epidemic, several interesting stories with a similar slant are featured; for instance, this one that says: tension in Mukuru slums after taxi driver is quarantined over corona virus. ${ }^{3}$

In yet another story, in the Sheng language, "Judgiko amekesi chini ya mti ku avoid korona" - translated into English, this headline says: a judge holds court session under a tree to avoid corona virus. This story followed an announcement by the country's Chief Justice to introduce the measures that would ensure the safety of judicial officers and the public from the corona virus during court proceedings. Some court sessions were therefore conducted in the open to ensure social distancing requirements among those involved.

Ghetto FM mainly targets the 15-25-year-old demographic category. In the last few years, Ghetto radio has been nominated for several awards such as best radio station, best show (goteana and gospel nite) and best presenters (Mbusii, Esther Kagamba and Angel Wainaina). A part from news, Ghetto radio's programming includes feature articles - for radio and the website. These features are also about slum life and provide a view that draws from the lived experiences of individuals drawn from the margins of contemporary urban life.

Generally, Sheng language is used to a certain extent on most of the radio stations in Kenya. However, it is Ghetto radio that has formally adopted and institutionalised Sheng as the main language for their radio programs. The pace at which Ghetto radio's daily radio programs such as "Goteana" evening drive show - and "brekko" - morning breakfast show - have attained popularity among Kenya's urban youth is testimony to the place that sheng occupies in the lives of many young people in the country.

\section{Ghetto Radio's programming and presenters}

Ghetto radio's key presenters uniquely fit the mission and character of the radio station. Unlike Kenya's mainstream media, whose core staff reflect Kenya's mainstream culture - educated, English and Kiswahili speaking and with the etiquette and general demeanour of the dominant economic and social elite, Ghetto radio's celebrated flagship presenters - such as Joseph Kangethe, also popularly known as Bonoko, and Nicholas Cheruyiot, popularly known as King Kafu - do not fit these mainstream media requirements for professionalism. The stories of their personal lives generally reflect a sense of abandon and a recklessness that is not normal in the context of mainstream Kenyan culture. Yet, these are the very qualities that they bring to their roles as key presenters on Ghetto radio.

Bonoko was formerly a street urchin, who started leaving on Nairobi's streets from a very early age. Born in Banana, a poor settlement on the outskirts of the city of Nairobi, he was, together with his siblings and mother, 
thrown out his home by his father. Left with no choice, he moved to the streets of Nairobi to find something to eat and a place to shelter. His street name was "Tete", and like every other street child of his age, he spent most of his time scrounging Nairobi's dumpsites for leftover food, or lazily sniffed glue while dozing under a street corner or in one of the city's many alleys.

One day, he witnessed a man being killed by security officers. As he narrates in an interview on KTN Prime News, this individual was shot for attempting to run away from city security officers who had spotted him urinating at a public place, which is against the city by-laws. When journalists came around to ask for information regarding the slain man, Bonoko sleepily volunteered to talk to the media, as the only authoritative primary witness to the incident. Bonoko says that it is after this event that the owner of Ghetto radio spotted him and requested for him to visit the radio station to shed light on this story.

While there, Mr. Jabel Julius Owino - popularly known as Gidi Gidi convinced Bonoko to stay on and just talk on their programs about life on the streets and in the slums for a salary. Bonoko stayed and his show "goteana" (Ghetto radio's evening drive show) has transformed into one of the most popular shows on radio in Kenya. Meanwhile, Bonoko has also transformed from a street urchin into a commentator and advocate for those who have to endure the degrading life and violence of the streets of Nairobi and other urban towns in Kenya.

Bonoko has been on Ghetto radio for almost five years now and acquired celebrity status by virtue of his radio presence. In the meantime, he has, using his salary, moved his mum and siblings into a decent house in one of the city suburbs where he continues to provide for them. Bonoko is also actively engaged in charity work mostly supporting various children homes around the city. Using the platform of his radio program, he has reached out to donors to contribute food and other material items to support orphaned children in these homes.

King Kafu - or otherwise by his official name Nicholas Cheruyiot - is the other celebrity presenter on Ghetto FM whose life has changed from that of a hard core criminal who snatched bags and planned car jackings around the city before joining the radio station to share his lived experience of crime and being born and raised in squalor and poverty in Nairobi's East lands area. In a TV prime time interview with Sophie Wanuna of KTN, which aired on 17 September 2014, he says that he spent six months in prison after being falsely accused of stealing a camera from a journalist. Later, after his release, he formed a team of young rascals whose work was to snatch, violently rob people of their valuables in the city. Without an education and parental care - since his parents died when he was still very young - this became his lifestyle until he landed the opportunity to work for Ghetto radio.

In 2006, after spending a year in prison for robbery with violence, a friend bailed him out, and soon he started looking for a job. He ended up working 
as a messenger at Ghetto radio, and after that, he was trained on the job as a radio presenter. He started the drive show - which became the most listened show - and then later, he was promoted to host the morning breakfast show also known as "Brekko" in sheng. Mr. Julius Owino, the founder of Ghetto radio, is quoted in an interview with the German TV (DW), saying that his motivation was to develop a radio station "that can learn", one that is adaptive and can provide a unique insider view into the craziness that attends life especially for the poor in Nairobi's slums. It would seem that hunting down, and convincing hard-core criminal and street urchins such as Bonoko and King Kafu was the best strategy for achieving this goal.

Shideh hosts Jamrock Doba night show on the Ghetto radio. This show features reggae music. Like Bonoko and King Kafu, Shideh does not have any formal training in journalism, nor does she boast of any firm roots in Kenya's mainstream culture. She is however fluent in sheng and has a deep understanding of the life of Nairobi's lower class areas such as Githurai where she previously worked as a small trader. Once on a vox pop recording mission in Githurai, Mr. Julius Owino - the Ghetto radio founder - noticed Shideh's fluency in sheng and knowledge of the local surroundings. This was exactly what he was looking for to reinforce the Ghetto radio brand. Shideh was hired and now she is one of the established and star presenters at Ghetto radio.

\section{Sheng the language}

According to several writers (see also Mazrui, 1995; Too \& Barno, 2016), Sheng language was developed as a code by gangs in the poorest sections of Nairobi. Although there is no clear evidence of the reasons behind Sheng's ascendancy, some studies have suggested that the youth in these areas of Nairobi devised this language to enable them to hide their secrets from their parents and seniors within the community. In other instances, it developed out of the need to communicate by a largely heterogeneous group of young people from the multiplicity of Kenya's ethnic groups who could not speak English or Kiswahili. Mazrui (1995) cites the case of Charles Otieno, who in a column published in Men Only (1984) reveals that, growing up in Nairobi's Eastlands area, in their parents' house they would speak in vernacular, but in the streets they had to find a way to easy communication since they were yet to go to school and did not understand English or Kiswahili - the two official languages.

Yet, in other instances, as argued by Too and Barno (2014), the origins of Sheng may have sprung from migration from various parts of Kenya to Nairobi and other urban towns in search of jobs. Those arriving tended to settle in the low-income areas of the city and mostly lived in crowded quarters. Sheng became a unifying code that enabled easy communication among people who spoke different first languages. Overtime, however, the influence of Sheng has grown as the language has also evolved. Mazrui (1995) argues 
that whatever its origin, Sheng is a slang based primarily on Swahili-English code switching, which serves mainly as a para code of mainly lower class urban youth.

Milu (2017) observes that Sheng is characterised by multiple discursive practices such as code mixing and switching, word coinage, innovation and inventiveness, semantic inversion and extension, unconventional spelling and pronunciation. In this regard, Sheng users draw from a diverse range of linguistic resources and hardly worry about proficiency. Given its roots in Kenya's urban slum culture, the language comes with its own fashion style - exhibited in dress, attitudes and gestures. Elsewhere, Samper (2003) identifies the role that manambas ${ }^{4}$ play as cultural agents in the shaping and development of Sheng language. They infuse a sense of defiance in the Sheng language culture, which, ironically, is at the root of the inventiveness and innovation that Sheng constantly draws from in its evolution.

\section{Ghetto Radio, Sheng and identity}

Sheng language is also about the struggle to construct identity - away from what Milu (2017) says are dominant, hegemonic colonising identities that have predominantly tended to define the modern Kenyan society. In this regard, Sheng can be seen as a decolonising cultural force. A key motivation in the founding of Ghetto radio was a recognition that today's youth, as Milu (2017) further argues, are engaged in a project of developing and projecting new ethnic identities and mostly shaped by their everyday language use. In the low-class and marginalised areas of Nairobi where Sheng found its roots, young people are undoubtedly confronted by different ideologies that tend to define them and this can be confusing. For this reason, they are locked in a constant struggle to locate and define an appropriate, flexible identity to fit their circumstances.

Ghetto radio plays an important part in this identity formation project for it provides a space for young people to escape a persistently hegemonic system with its mainstream practices and culture. Those lacking competence in these two languages - mostly represented by the audience that Ghetto radio's Bonoko speaks to - have constantly felt different and excluded. However, using his Goteana (evening drive show), Bonoko provides reassurance, comfort and belonging to this group, which mainly comprises what one would be referred to in Sheng as "Wasee wa ghetto" ghetto guys or those on the streets including school drop-outs, the unemployed, and informal sector (jua kali) workers. In this way, Ghetto radio, and its Sheng speaking - from "the street heroes" such as King Kafu - give young people hope and a cultural thread to hold onto in a turbulent world. Those struggling with unemployment and poverty see role models in Bonoko and King Kafu who are now successful and famous in spite of the fact that they started out on the streets and have experienced the hard life of street crime. 
Kenya has 42 ethnic groups, each with its own language. English and Kiswahili are the two national languages by which formal transactions are carried out. These are also the languages of instruction for the country's education system. Primarily, and as observed by Milu (2017), it is from these languages that a majority - up to $99 \%$ of the population - derive their primary ethno linguistic identities. However, looking at the country's history from colonial times to the present, this ethno linguistic characterising has also been at the heart of the country's major social, political and economic challenges. The country's national elections have increasingly become a source of conflict - mostly pitying ethnic groups or blocks. This is primarily due to the reason that ethnicity and national economic and political interests are closely intertwined.

For this reason, ethnic groups want to feel that they have a stake through representation by one of their own in the national political hierarchy of power. Ultimately, elections have become a zero-sum game. Kenya's establishment media, including the more recently established commercial radio stations across the country, are easily sucked into this mix, as they openly tend to perpetuate this situation by repeatedly focusing on ethno linguistic differences and assigning ethnic tags to political players on the national scene. In this context, and with ethno language differences accentuated, it is always clear who belongs where and whose interests are at stake. Inevitably, support for political parties tends to take the ethnic angle, with little or no consideration given to policy ideas espoused by the different political formations.

Sheng language, however, provides a melting pot - a cultural space in flux! In this way, it enables those who belong to its culture to remove themselves from mainstream identity characterisations that have traditionally been associated with the dominant ethnic groups in the country. Milu (2017) argues that the sheng language space enables Kenya's youth to resist hegemonic racial and ethnic identification practices - a form of ethnic activism that challenges the country's dominant modes of ethnicity.

\section{Ghetto Radio and hybridity}

At another level, sheng language, according to Samper (2003), is also a point of convergence between the urban, global and cosmopolitan with the rural, local and traditional - a seamless juncture between Kiswahili, English and the local languages. In this regard, Sheng is further seen as a form of hybridity in practice. Hybridity in this sense is viewed as an opportunity for forging what Milu (2017) refers to as emergent ethnicities, away from dominant, hegemonic and colonial ethnic identities. Consequently, sheng affords a hybrid identity space where the most unlikely characters such as Bonoko, King Kafu and Shideh come to assume recognisable status, becoming celebrities for their fans who comprise a culturally, nonmainstream audience. 
Ghetto radio can therefore be defined as a project in cultural hybridity. Smith (2008) argues that cultural hybridity is beneficial, especially in today's changed and globalised world. It affords one the opportunity to negotiate across barriers - language, cultural, spiritual, racial and physical. This is possible because the hybrid contains elements of the local and the global, and the intermixture makes it unique. In this regard, those occupying hybrid spaces have an understanding of both the local and global cosmopolitanism. They can easily cross borders in a world of amorphous borders. Bonoko's "goteana" - evening drive radio show - is possibly a perfect example of what hybridity may imply in this case. The show is rendered in the Sheng language, but is interlaced with music that draws from global popular artists - itself a feature of global cosmopolitanism. Bonoko, however, is a child of the streets and nothing about his presentation of the show betrays this. Nonetheless, in spite of his background, he uses his show to talk to a largely cosmopolitan audience, who find him normal, unique, contemporary, entertaining, crass, unhinged all rolled up in one.

In this way, he is able to seamlessly glide across the various boundaries cultural, local, global with ease. His show is organised to conform to current trends in the entertainment industry, which combine information and entertainment in uniquely creative ways to build audience numbers. Yet, it also has a superb blend of the uniqueness of Nairobi's urban slums and those who experience its attendant life of squalor on a daily basis. With time, and in the spirit of hybridisation, Ghetto radio enables a coinfluencing between the local and the global, where the local is universalised and the universal is localised. This process of hybridisation can also be understood in the context of translingualism, with respect to the Sheng language. Translingualism describes the dynamism with which speakers move across different types of multilingualism as they construct their ethnic and linguistic identities. Milu (2017), for instance, notes that with the spread of the global hip hop, reggae and dancehall music, elements of other international linguas - such as African American language, Jamaican Creole and Dread Talk have, for instance - found themselves enmeshed into the Sheng language.

Consequently, Ghetto radio's use of the Sheng language exhibits strong elements of translingualism, ultimately enabling the formation of hybrid cultural-linguistic spaces. The resulting hybrid space is flexible, constantly changing and adaptable to the shifting needs of urban slum life. Smith (2008) notes that hybridity is a subversion of hierarchy, thus enabling the formation of a truly multicultural society. In the case of Kenya, Sheng language subverts traditional ethno linguistic barriers, as local languages enmesh to create a cultural hybrid, a process to which Ghetto radio has evolved into and, in turn, is an important agent.

While Kenya's establishment media has tended to promote mainstream culture, as exemplified in the privileged prominent (news) voices who are mostly drawn from the country's economic, political and social elite, Ghetto 
radio's primary news voices are drawn from the back streets and Nairobi's low-end residential areas. Yet, with creativity and cultural imagination, two core things at the heart of hybridity (Smith, 2008), these two worlds the global and Nairobi's street life - are brought together in Ghetto radio's programming. Bonoko, King Kafu and Shide subsequently become the co-creators and cultural agents of the emerging reality of partial identities, multiple roles and pluralistic selves.

\section{Ghetto Radio and a postmodern perspective}

It may be useful to note at the onset that the Kenyan society, and its media system may not, in the very ideal sense, be described as a postmodern society, similar to observable trends in the Western world as described and discussed by various authors such as Wood (2003). One however recognises instances where Ghetto radio - itself a product of the unrelenting forces of globalised communications - approximates the general of sense of dynamism, diversity and difference which characterises contemporary media cultures. Ghetto radio, in other words, is a mirror reflection of today's mixed media culture - what Kovach and Rosenstiel (1992) describe as a diversified media culture in which cultures of entertainment, infotainment, argument and analysis intermingle and merge. Prominent scholars on the media and culture such as Ang (1998) and Fourie (2005) use terms such as pluralism, heterogeneity, ambivalence, hybridity and hesitation to describe this emerging reality.

In a similar vein, McQuail (2003) refers to a media and communications reality that is defined by unbounded freedom and diversity essentially allowing for out of the norm behaviour as we note with Ghetto radio. Giddens (1990) uses terms such as disembeddedness and reflexivity to describe these new trends. These references are reflective of what Wood (2003) sees as the postmodern moment - one that is defined by instability. It privileges spontaneity and chooses a loose form of moral relativity, thus leading to the transformation of what was traditionally regarded as modern civilisation and its focus on certainty based on reason and structure. For Jameson (1983), postmodernism is also a periodising concept whose function is to correlate the emergence of new formal features in culture - the society of the media or the spectacle.

Generally, the postmodern moment is manifest in the quest by today's society to liberate itself from what Wood (2003) refers to as the tyranny of history and the rigidity of truth seeking and the burden of responsibility. The emerging era and society is one that is defined by a sense of general abandon, ambiguity and a vague sense of loss of coherence. It can be argued that the society to which Bonoko and King Kafu are heroes and celebrities - two former street rascals - is one that is keen to recreate a dominantly top-down social hierarchy. In the process, new voices, heroes and heroines emerge out of the story of Ghetto radio. The playfulness with which Ghetto radio will 
recast mainstream news subjects to reflect the interests and the lived circumstances of Nairobi's low-class settlements is telling of postmodernism's embrace of the chaos of modern life.

The general style of programming and presentation adopted by Ghetto radio's daily shows is largely reflective of general trends in today's pop culture and infotainment world. This for instance includes trends such as joke for jokes' sake character of most programming which predominates instead of serious content, substance and meaning. In other words, Ghetto radio's shows are not meant to provide their audience with a serious feel of the events of the day nor are they cast in intellectual depth and analysis. Segments of the audience seeking serious or in-depth analysis of the day's news and events have to look elsewhere. In the same vein, mainstream (authority/prominent) news voices will most likely be missing from Ghetto radio's Sheng news bulletins. This very important consideration in writing or scripting of news is not recognisable in Ghetto radio's sheng news bulletins. Instead, it is ordinary voices - urban slum dwellers who take center stage as privileged news voices.

Yet, in the same vein, postmodernism is, as asserted by Strinati (1992), also an attempt to understand today's media saturated world. Various media types and varieties emerge to cater for differentiated tastes and preferences. Ghetto radio's ascendancy is largely connected to the need to provide a media space to a non-mainstream audience - Nairobi's backstreets, slums and low-grade living areas. This contrasts with other niche radio stations in Kenya, such as Capital FM, which are oriented toward catering for Kenya's upper income brackets. The station airs commercials and general advertising that is targeted at a prosperous domestic market. Among others, Capital FM carries advertisement on golfing tournaments, mortgage companies and vacation packages. All these will not feature on Ghetto radio, whose target audience embraces a different lifestyle and world view. However, in spite of these differences, Ghetto radio, just as much as the whole lot of emergent commercial radio stations around the country, exemplifies contemporary mass media's take over or what Strinati (1992) refers to as a cultural inversion of our senses - and which knows no boundaries.

Postmodernism's rejection of metanarratives or universalising "knowledges" and social practices (Lyotard, 1984) offers yet another critical angle through which we attempt to understand Ghetto radio's unique position. We are told postmodernism is skeptical of any absolute, universal and all-embracing claim to knowledge, thereby exposing theories or doctrines which make such claims open to criticism, contestation and even doubt. Ghetto radio's claim to fame is its unorthodox presentation styles, cast of presenters whose personal stories and by extension personalities do not reflect dominant cultural trends, and the total embrace of the Sheng language. In this disposition, one discerns strong oppositional tendencies, and an attempt to embrace and bring to the mainstream, voices and media practices considered non-mainstream and uncultured within the Kenyan society. 
It is this embrace of the "other" - the non-normal side of life - represented by non-mainstream narratives that draw from the lived experiences of Bonoko, King Kafu and Shideh as the true voices and faces of those from the margins of Kenya's contemporary urban society that qualifies Ghetto radio as a postmodern (cultural) project. This very characteristic distinguishes Ghetto radio from Kenya's mainstream media culture, which is founded on and guided by traditional ethical and professional considerations - guided by a code of ethics for the media and a cast of general normative expectations by society. Postmodernism, however, embraces mediocrity (Bonoko, King Kafu) and rewards all equally (Bonoko and King Kafu's celebrity status). Yet, as Wood (2003) further asserts, in a postmodern world, there is little originality or skill displayed - which is the case with Bonoko and Kafu who have made a name on radio but without any formal mastery of skill of professional knowledge.

Further, to be neat and orderly, to demonstrate any lyricism or to display any actual talent is considered somehow elitist. Listening to key programs on Ghetto radio and Bonoko's or Kafu's flagrant vulgarities rendered in the Sheng language, one would easily dismiss the dominant non-serious style as spontaneous silliness. Overall, Bonoko, Kafu and Shideh represent a general playfulness and non-professional approach to media business associated with the non-professional. Where Kenya's mainstream media will compete to hire the most professional, talented, educated radio and television presenters, Ghetto radio is at home with Bonoko - a child of the streets or King Kafu a self-confessed former violent criminal. In other words, affirming the observation by Woods (2003) on the nature of postmodern art, to be civil is to be snobbish, to be talented is to be elitist. Ultimately, Bonoko, King Kafu and Shideh seem to urge us to accept life with all its absurdities - as it is.

\section{Conclusion}

This chapter sets out to demonstrate the place and significance of nonmainstream media spaces such as that provided by Nairobi's Ghetto radio 89.5 FM in contemporary society. In preceding sections, we have shown the unique media culture that Ghetto radio has demonstrably assisted to nurture through the use of the Sheng language. The vibrancy of Ghetto radio's programs and its unique and out-of-norm daily show presenters are illustrative of the power of non-mainstream media spaces in empowering and subsequently bringing to the mainstream voices and narratives hitherto considered anathema to mainstream culture. Through Ghetto radio's programming and audience base, one sees an attempt for non-mainstream voices to ride on new postmodern trends to find space in a dominantly topdown, hierarchical society that has traditionally had no space for them.

Subsequently, voices from Nairobi's backstreets and the poor urban settlements embodied in Bonoko, King Kafu and Shideh find acceptance in a 
new world that must embrace the chaos of our lived experiences, mediocrity and the simplistic stories of the streets in order to find a balance. Yet, as we have also observed, Ghetto radio serves to bring together a confluence of cultural influences, especially as expressed through the Sheng language. Through the Sheng language, cultures meet and mingle, the global and the local are enmeshed. The end result is inimical to traditional ethno-cultural identities. It takes the format of a fluid, discontinuist cultural space that provides a restless youthful audience a convenient and shifty space where they are active agents - co-creators of culture.

Consequently, Ghetto radio's role as an oppositional cultural space manifests in its embrace and ability to nurture new forms of creativity, expression and politics. Its heroes and heroines are from the streets and therefore bring a rich mix of lived experiences to the station's programming, especially the manner and language with which they engage the audience. As shown in preceding sections, these presenters do not mirror the sophistry of traditional culture, neither do they come armed with the professional tools and ethics of journalism. Bonoko and King Kafu have not demonstrated history of formal learning, but their voices have assumed undeniable significance in Kenya's media sphere. On the whole, these trends provide a glimpse into the potential of media to contribute to the emerging forces of decolonisation (from hegemonic cultural tendencies) within contemporary Kenyan society.

\section{Notes}

1 Sheng is largely regarded as the unofficial language of the urban (Nairobi) streets. It is popular among the youth and people living in Kenya's informal settlements. Sheng language borrows mainly from Kiswahili and English, and depending on where it is used in Kenya, a sprinkling of words and phrases from the local ethnic language of the area will feature prominently in the sheng variety of that locality.

2 This was published on 17 March 2020 as one of the trending news stories on Ghetto radio.

3 Available [o] https://www.ghettoradio.co.ke/tension-in-mukuru-slums-after-taxi-driveris-quarantined-over-coronavirus/ accessed on 19/3/2020

4 Young men who work in Kenya's public transport vehicles, popularly known as matatus.

\section{References}

Ang, I. 1998. The Performance of the Sponge: Mass Communication Theory Enters the Post Modern World, in The Media in Question: Popular Cultures and Public Interests, edited by Brants, Hermes \& van Zoonen. London: Sage Publications.

Dunber-Hester, C. 2014. Low Power to the People: Pirates, Protest and Politicians in FM Radio Activism. Cambridge, MA: The MIT Press.

Fourie, P. J. 2005. Towards Linking Normative Theory, Communication Policy and Audiences in South Africa Communication Research, Communication, 31(1): $17-40$.

Giddens, A. 1990. The Consequences of Modernity. Stanford, CA: Stanford University Press.

Hornsby, C. 2012. Kenya: A History Since Independence. London: I.B Tauris. 
Ismail, A. J. and Deane, J. (2008), 'The 2007 general elections in Kenya and its aftermath: The role of local language media', International Journal of Press/ Politics, 13(3): pp. 319-32.

Jameson, F. 1983. Postmodernism and Consumer Society, in The Anti-Esthetic: Essays on Postmodern Culture, edited by H. Foster. Washington, DC: Bay Press.

Mazrui, A. M. 1995. Slang and Code-Switching: The Case of Sheng in Kenya, AAP, 42: $168-179$.

McQuail, D. 2003. New Horizons for Communication Theory in the New Age, in A Companion to Media Studies, edited by A. Valdiva. UK: Blackwell Publishing: $19-40$.

Milu, E. 2017. Translingualism, Kenyan Hip-Hop and Emergent Ethnicities: Implications for Language Theory and Pedagogy, International Multilingual Research Journal, 2(12): 96-108.

Kellner, D. M., \& Durham, M. G. 2006. Adventures in Media and Cultural Studies: Introducing the Keyworks, in Media and Cultural Studies: Key works, Revised Edition, edited by David Trend. Oxford: Blackwell Publishing.

Kovach, B., \& Rosentiel, T. 1999. Warp Speed: America in the Age of Mixed Media. New York: The Century Foundation Press.Lyotard, J.-F. 1984. The Postmodern Condition: A Report on Knowledge. London. Manchester University Press.

Ogolla, G. 2011. The Political Economy of the Media in Kenya: From Kenyatta's Nation Building Press to Kibaki's Local Language FM Radio. Africa Today, 57(3), 78-95.

Samper, D. A. 2002. Talking Sheng: The Role of a Hybrid Language in the Construction of Identity and Youth Culture. PhD Thesis.

Smith, K. E. L. 2008. Hybrid Identities: Theoretical Examinations, in Hybrid Identities: Theoretical and Empirical Examinations, edited by K. E. L. Smith \& P. Leavy. Boston, MA: Brill.

Strinati, D. 1992. Postmodernism \& Popular Culture, in The Media Studies Reader, edited by T. O'Sullivan \& Y. Jewkes. London. Arnold.

Too, S. K., \& Barno, H. C. 2016. The Camouflaging of Sheng in Kenya Since Its Emergence, Baraton Interdisciplinary Research Journal, 6(Special Issue): 157-162.

Wood, D. N. 2003. Unraveling of the West: The Rise of Postmodernism and the Decline of Democracy. London. Praeger. 


\title{
12 Social media as a sphere of political disruption
}

\author{
Trust Matsilele and Bruce Mutsvairo
}

Since the turn of the millennium, there has been a proliferation of social media use in political and ideological contestations. This proliferation has been reflected in a raft of scholarship that seeks to cognise the potential of new communicative technologies. A cursory look at the studies conducted demonstrates that most research has tended to look at the nexus of social media and elections, democratisation, political activism and protests (Mäkinen \& Wangu Kuira, 2008; Wasserman, 2011; Mpofu, 2013; Smyth \& Best, 2013; Mare, 2014, 2016; Mhiripiri \& Mutsvairo, 2014; Chitanana \& Mutsvairo, 2019; Matsilele \& Ruhanya, 2020; Mpofu \& Matsilele, 2020; Mutsvairo \& Ronning, 2020). What remains under-studied, with an exception of the few studies in the Western hemisphere, is the relationship between social media and political disruption in political hybrid systems where there are cosmetic freedoms and elements of dictatorship co-existing side by side like in the case of Zimbabwe. Just like normal democracies, Zimbabwe holds elections every five years, but the same elections are marred by violence, legitimacy deficit and dual deployment of law and other coercive apparatus of the state. Writing on hybrid political systems, Levitsky and Way (2010:1) intimated that:

Unlike the single-party or military autocracies that predominated during the Cold War era, regimes in Kenya, ... Zambia, Zimbabwe, and elsewhere were competitive, in that opposition forces used democratic institutions to contest vigorously — and at times successfully - for power. Nevertheless, these regimes were not democratic with government critics suffering harassment, arrest, and in some cases, violent attacks, and electoral fraud, unfair media access, and abuse of state resources skewed the playing field heavily in favour of incumbents. In other words, competition was real, but unfair.

It is in these hybrid systems where social media has been used to supplement offline activities that often have attracted severe punishment from the state as evidenced by use of naked violence in Zimbabwe in August of 2018 and January of 2019 when live ammunition was used on unarmed civilians.

DOI: $10.4324 / 9781003111962-12$ 
Of importance, however, is the effective use of social media as a platform for potential alternative discourses and narratives, which leaves these digital arenas attractive in authoritarian states as subalterns, which Spivak (1988) equates to the oppressed victims of cultural imperialism can dress parodies on social media and employ them as "foot soldiers" to fight against oftentimes oppressive and despotic regimes. It is social media's enabling capacity to use parody accounts, where citizens are not compelled to use their real identities but they can use avatars, made up identities, multiple identities, or stay anonymous that has ignited its popularity (Coleman, 2014). The use of parody accounts was in use as recent as 2020 in Nigeria with the \#EndSars protests that sought to push back against the state sponsored brutality (Bodunrin \& Matsilele, forthcoming). In countries such as Kenya, Democratic Republic of Congo (DRC), Nigeria, Togo and Zimbabwe were electoral outcomes have been contentious, digital media has become an alternative space for contestations and counter-narratives. It is this contestation that leads Banda (2010: 8) to intimate that, 'citizens through social media are beginning to own their own media and counter the effects of years of reportorial neglect occasioned by an unhealthy concentration of media ownership' and enjoy monopoly traditionally reserved for elites only (Mutsvairo and Sirks, 2015). Notwithstanding these promises of social media, there are still challenges around access, affordability and connectivity which explain, in part, why most Africans remain disconnected from the so-called information superhighway. Despite these challenges, social media could be used to broaden political participation by helping citizens to communicate with their representatives and with each other (Valenzuela et al., 2009). It is this aspect by Valenzuela et al. (2009) that informs this study - in a bid to understand how social media is employed to disrupt the communicative aspect of power. In Zimbabwe, actors who disrupt power have often been dressed in terms that attract annihilation, terms such as dissidents. This characterisation of opponents as dissidents in Zimbabwe has a history. "Dissidence" is vapanduki or what the current President Emmerson Mnangagwa calls mhanduin reference to enemies and rebels of the state (Matsilele, 2019). This specific form of dissidence that occurs mostly on social media platforms is what this chapter refers to as social media dissidence. In this chapter, we ask if it has some decolonialising effect.

\section{Theoretical framework}

The study employed two theoretical lenses: a reconfigured public sphere and subalternity. The public sphere of social media is not even strictly "public" because social media platforms are privately owned, and the public can be locked out or banned from the app by the corporate owners or by other users. Furthermore, assumptions that social media are available for free to the public remain largely illusory because the companies that own such 
platforms are constantly collecting users' data to sell or to use it to learn more about the users' habits (Isaak \& Hanna, 2018). The owners also make money from users through constant software upgrades. Thus, when the framing concept of public sphere is in relation to social media use, the intention is to modify the terms "public" and "sphere" so that they fit the following: the Zimbabwean context, the political concept of "public", the sociological concept of "social" and the communication concept of "media". This bundle of ideas makes up a kind of public sphere that Habermas would probably struggle to recognise straight away. This is because there is a concept that is unique to Zimbabwe that explains the public sphere a bit more organically than Habermas' coffee shop model. For its part, Zimbabwe offers the concept of dariro or playground. The second theoretical lens used in this study considers dissidence to be a subaltern practice, a claim that simultaneously opens opportunities and limitations for the current chapter. Mpofu (2015: 83) has argued that 'the Web 2.0 has revolutionised participation in salient public discourses of those ostracised Zimbabwean members of society' whom Fanon (1969) and Gramsci (1971) have categorised as "the wretched of the earth" or "subaltern" respectively. Like in the case of the public sphere, the study is not limited to seeing the subaltern in relation to post-colonial India or Mussolini's Fascist Italy. The subaltern of Zimbabwe is a product of Zimbabwe's history, whose identity and agency are now refracted through the keypad, touch screen and camera of a smartphone. When one reads subaltern theory into Zimbabwe, what comes out is something else that looks and sounds like Spivak's subaltern dictum (1988), but with a Zimbabwean kongonya (a provocative dance) flavour. That fundamental shift should be considered. This shift welds the subaltern margins to the public sphere, mediated by hashtags, memes, trolls, news feeds, timelines and so on.

\section{Research methodology}

To understand the phenomenon of social media dissidence in Zimbabwe in as far as political disruption is concerned, the study employed qualitative methodology with research designs of virtual ethnography and case study. Online ethnography refers to a number of related online research methods that adapt to the study of the communities and cultures created through computer-mediated social interaction (Bowler, 2010: 1270). In this case, the researchers studied the emerging culture of political disruption mediated in Zimbabwe's virtual public sphere. The second design used was the case study. Case studies, in their true essence, explore and investigate contemporary real-life phenomenon through detailed contextual analysis of a limited number of events or conditions, and their relationships (Tellis, 1997; Zainal, 2007). This chapter focused on \#ThisFlag movement to understand how "dissidents" are disrupting hegemonic narratives in Zimbabwe's reconfigured public sphere. 


\section{Discussion and analysis}

\section{The political disruption of \#ThisFlag movement}

\#ThisFlag begun in April 2016 led by Evan Mawarire, then a 41-year-old Zimbabwean pastor who appeared with a Zimbabwean flag draped around his neck and shoulders in a video posted on Facebook, YouTube and Twitter. \#ThisFlag uses social media to register widespread socio-economic anger against the Zimbabwean state. The movement also uses social media (Twitter and Facebook) to mobilise support against what it considers a repressive state a view Gainous and Wagner (2014: 136) theorise when they say, 'social media allows political actors to garner support beyond the purview of mainstream media'. Mawarire also uses the social media platform due to its affordability and uniqueness in terms of communicating with his target audience. \#ThisFlag would never have taken off in 1990, 2000 or 2010 when ZANU-PF monopolised the airwaves. As Gainous and Wagner (2014: 136) have further observed, 'the result is that campaigns on the Internet are an alternative that allows competition where limited resources might have provided none' and for the case under study competition beyond the political direction of the country extends to control of narratives in the country's virtual public sphere.

The social media campaign allows for easier outreach and education of the voters at a fraction of the cost of traditional media. While Mawarire is not always directly targeting voters, his targets - citizens - particularly those opposed to the ruling party - potentially wield the same power as voters who could punish elected officials at the ballot box. The movement is active on Facebook and Twitter. On the Twitter platform, the campaign operates under several handles, such as \#ThisFlag and E Mawarire @ PastorEvanLive. On Facebook, the movement uses the names Mawarire and This Flag/Ifulegi Leyi/Mureza Uyu. As of April, 2021, on Facebook, Mawarire's handle had 94,169 followers, while This Flag/Ifulegi Leyi/Mureza Uyu had over 120000 likes and followers combined. On Twitter, Mawarire had over 325,000 followers early 2021 .

\section{History of the movement}

The movement uploads self-made videos of Zimbabweans venting against the state, and sometimes trolling it. The rallying call is around the significance of the national flag which they say originally represents noble values such as shared prosperity, democracy and the country's potential in agriculture and mining, but which has now been soiled and inverted, they argue, by ZANU-PF. The posts are made by users mostly using their real identities. For instance, Mawarire, unlike Baba Jukwa (another social media dissident who used an alias), has a traceable biography, a factor which points to his distinct mode of dissidence. He grew up in Mazowe, about 37 
km outside Harare, where he attended Prince Edward High School and the Harare Institute of Technology. He is a married family man with two children. Mawarire is the charismatic leader of His Generation Church, a small church in Zimbabwe's capital Harare. \#ThisFlag began with a four-minute video, posted on 20 April 2016 on Facebook, WhatsApp, YouTube and Twitter (Musarurwa, 2016).

The video went viral, gaining 77,000 views on YouTube and 185,000 on Facebook. He also tweeted, on the same day he posted the video, "So I had a little rant \& it has turned out to be how so many Zimbabweans feel". By May 2018, Mawarire had posted over 3,400 tweets and over 430 photos and videos. There were also thousands of comments, over 7,000 likes and retweets. By 5 May 2018, Mawarire had 204,000 followers. On the 5th of July 2016, Mawarire posted a video exhorting Zimbabweans to stay away from work the next day as part of a nation-wide shutdown. Over 48,000 followers viewed the video. The video was coupled with a poster calling on Zimbabweans to stay at home and not report for work. The poster was loved 103 times, retweeted 126 times, with 14 replies.

The shutdown was successful, leading to the government charging Mawarire with treason, an offence punishable by death in Zimbabwe. After a court appearance and securing bail, Mawarire skipped the country at the end of July 2016, first to South Africa, then to the United States, where he currently lives. While in South Africa, he continued to drum up support across South African churches and universities.

After skipping the country, Mawarire would become a guest of local, regional and international media outlets. Among them were CNBC Africa, CNN, BBC, SAFM, Kaya FM, 702 and EWN. His family followed him to exile to South Africa and then the U.S. It is these transitions between online first then offline that is also of interest to understand as dissident figures like Mawarire start by employing tools at their disposal and then transition to bigger platforms once they have built a critical following online. After a stay outside Zimbabwe of seven months, Mawarire returned to Zimbabwe on 1st of February 2017, where he was immediately arrested on entry. He has since relocated to the United States.

\section{Findings and analysis}

\section{Discussion of types of content: \#ThisFlag}

Four types verbatim emerge on Mawarire's \#ThisFlag's page: call to action, protest, motivational and trolling. The content on Mawarire's Twitter and Facebook handle, like Baba Jukwa's, has as its end the throwing of power into disarray by asking uncomfortable questions, employing tactics that are difficult to censor or prohibit (that is, actions that can only be censored at great reputational cost to the regime), and encouraging followers to bypass traditional gatekeepers by self-recording and uploading content 
that makes the government look incompetent or just plain bad. The content on Mawarire's \#ThisFlag page is also meant to inspire "courage" against alleged tyranny without engaging in an open combat. Unlike other digital dissidents like Baba Jukwa and Tajamuka who call for physical confrontation with the state, Mawarire opts for what could be considered more of a "Martin Luther King approach" - confronting power through peaceful means and powerful oratory rhetoric which mobilises citizens to courageously confront, question and expose the hypocrisy demonstrated by powerful elites.

Table 12.1 demonstrates some of the identified broader categories of Mawarire's disruption.

Mawarire posted different kinds of content. His very first, famous video is an example of protest. This is because it questions the leadership of the country, asking for a balance sheet of what it has done since taking over after independence. He laments the state of the economy and argues that the country is a far cry from what it should be. In this way, Mawarire fires the imaginations of Zimbabwe, partly by invoking nostalgia for a functional Zimbabwe (late 1980s to mid-1990s). Mawarire also posted many other videos besides the first well-known video. For instance, he posted the video calling for the national shutdown. We categorised that video as "call to action". This is because he is urging fellow citizens to stay away as a sign to the government that citizens will not sit by and watch while governing party runs down the country through corruption and incompetence. Staying away from work is one example of peaceful protest which is difficult to

Table 12.1 Broader categories of Mawarire's disruption

\begin{tabular}{|c|c|c|c|}
\hline Type of content & Example 1 & Example 2 & Example 3 \\
\hline Protest & $\begin{array}{l}\text { Mboko (then vice } \\
\text { president) buda } \\
\text { muhotera ( } 24 \\
\text { June 2016) }\end{array}$ & $\begin{array}{l}\text { We don't want them } \\
\text { (Bond Notes) } \\
\text { debate with RBZ } \\
\text { governor (10 June } \\
\text { 2016) }\end{array}$ & $\begin{array}{l}\text { Another rant } \\
\text { against Mugabe. } \\
\text { There will be } \\
\text { more no doubt } \\
\text { (1 June 2016) }\end{array}$ \\
\hline Call to action & $\begin{array}{l}\text { Let's gather to } \\
\text { honour Dzamara }\end{array}$ & $\begin{array}{l}\text { Shut down } \\
\text { Zimbabwe (5 July } \\
\text { 2016) }\end{array}$ & $\begin{array}{l}\text { Undenge Must go } \\
\text { (2 July 2016) }\end{array}$ \\
\hline Trolling & $\begin{array}{l}\text { Notice to sue police } \\
\text { over malicious } \\
\text { arrests (23 March } \\
\text { 2018) }\end{array}$ & $\begin{array}{l}\text { Celebrating } \\
\text { blockage of } \\
\text { Beitbridge border } \\
\text { (1 July 2016) }\end{array}$ & $\begin{array}{l}\text { Profiling NERA } \\
\text { demonstration } \\
\text { (26 August 2016) }\end{array}$ \\
\hline $\begin{array}{l}\text { Informational/ } \\
\text { motivational }\end{array}$ & $\begin{array}{l}\text { Updates on } \\
\text { his speaking } \\
\text { engagement } \\
\text { at Geneva ( } 20 \\
\text { February 2018) }\end{array}$ & $\begin{array}{l}\text { Updating followers } \\
\text { about meeting } \\
\text { Mapfumo (20 } \\
\text { August 2016) }\end{array}$ & $\begin{array}{l}\text { Inviting } \\
\text { Zimbabweans } \\
\text { to attend court } \\
\text { in support for } \\
\text { Tajamuka activist } \\
\text { (26 August 2016) }\end{array}$ \\
\hline
\end{tabular}


censor. It had previously been used successfully by the nation's trade union federation ZCTU and the MDC in the late 1990s and early 2000s but had fallen into disuse as the citizenry became apathetic from the mid-2000s onwards (Zeilig, 2016; LeBas, 2006). In the same month as the \#Shutdown Mawarire would post another video with a different kind of tone and message, saying:

Fellow citizens let me thank you for standing up to this government over corruption and injustice......Today I want to thank political and civil activists who have stood up against this government for a long time. It is because of you that we are also standing up now... Nothing is called useless when it comes to challenging this government as far as running our country is concerned...... Hatichada uye hatichatya (we are no longer afraid and can't take this anymore).

Here, Mawarire is not merely expressing his thanks and praises to dissidents_ past and present_but he acknowledges a debt and genealogy of dissidence in Zimbabwe. This aspect strengthens this study's contention that dissidence in Zimbabwe is deeply rooted in history, not just a social media phenomenon. At the same time, by saying "Hatichada uye hatichatya" translated to mean "we are tired and we are no longer afraid," he seeks to embolden the masses with a rare ray of hope in a country, where amid government denials, opposition officials believe has become a possible outpost of tyranny. Is it a mere bluff to say he and his followers are "no longer afraid". The evidence suggests that indeed some Zimbabweans - once they resolve to fight - do so with their lives. Spirit medium Nehanda facing death declared "Mapfupa angu achamuka" or "My bones will rise again" while the Second Chimurenga guerrillas sang "Amai naBaba/musandichema kana ndafa/nehondo" (Mum and dad, do not weep for me if idea in this struggle). These words are words of resolve and when Mawarire says "hatichatya" he could be evoking historical precedence of paying the ultimate price in pursuing freedom and justice.

Another type of content that Mawarire posts is what we categorise as informational. Dissidents should demonstrate to followers that their actions are working, to inspire citizens to continue to be engaged. Mawarire does this by giving periodic updates to the followers of his speaking engagements in Geneva, at the United Nations, and meetings with eminent persons such as civil rights movement leaders in the USA and anti-apartheid activists in South Africa. Such connections help show to Mawarire's constituency that their fight has support across the world. The oxygen of visibility is important to social media dissidence. Below Mawarire was captured with one of South Africa's late struggle icons, Ahmed Kathrada, who spent over two decades in Robben Island with Nelson Mandela.

Mawarire is not the only contributor to videos and messages to \#ThisFlag. Indeed, \#ThisFlag rose to become a movement precisely because it 
quickly outgrew Mawarire himself. For instance, we see two anonymous youths from Kadoma who "joined" the movement in April of 2016 and immediately posted a video of themselves holding the Zimbabwean flag and addressing themselves to the country's President:

Dear Patriarch Mugabe, our roads from Kadoma to Jarahwa are dilapidated. The Chinese who are doing mining here are not assisting the situation. The seeds you are sending isn't getting to the intended beneficiaries. We are asking that you question the member of parliament from our region regarding to any development he has brought to the area since he got elected.

We seek to categorise this content as "protest". This is because it seeks to expose members of parliament, who get trapped through the benefits of positions they occupy and thereby forget the historical mandate of serving the people. This is the historical Fanonian pitfalls of national consciousness. The critique it levels at "Dear Patriarch Mugabe" is of a kind that we consider condescending mockery (kusvereredza). It appears that the youths were attaching a title to Mugabe they knew he did not deserve. Another Zimbabwean, Harris Madhuku, was influenced by \#ThisFlag to "protest" and thereby posted a video in English, saying that:

Today I want to talk about how things are being run in the country. There is something troubling especially the quick implementation of instant laws at the port of entry in Beitbridge it's a sign of dryness and barrenness in terms of ideas. They are running our country like they are running their houses or a tuck shop.... Other countries see us as stupid people.... The Occupy Africa Unity Square activists were charged with attempted robbery, how can you ask for a one "thousand-dollar bail in a country where you can't withdraw two hundred dollars... We kind have a country being run by greedy minds, come out of comfort zones when you see people protesting join that demonstration. They can't sleep in mansions whilst we sleep in streets....

The researchers considered this content as call to action. This is because it urges citizens to be active and join protests the way the country is run. Interestingly, the call to action is not made by Mawarire, but by fellow Zimbabweans responding to \#ThisFlag's original call to action to make their own calls to action. Thus, \#ThisFlag becomes a rallying point. This is a kind of piggybacking on dissidence - where dissidence spawns more dissidence. Opposition leader Madhuku, whose message is that Zimbabwe has been privatised by an elite and that citizens should fight back to retake the country, has been mobilised to mobilise others. \#ThisFlag had grown beyond Mawarire and even beyond the hashtag. Even though Mawarire was confined to the online space, his "followers" push for other varieties of engagement that 
spill out into the streets. In May 2016 two war veterans, also from Kadoma, posted a video in which they said:

I also hold my flag to Mr President to register my disgruntlement. There was a company that was here, it has now closed down; this company was owned by your fellow liberation fighters. About 70 people were working here until the company got closed down. The people who were running this place were dispossessed of their belongings by ZIMRA and NSSA. These people who used to run this place are now desperate and we hope this message will get to you, so you can come and help the situation. Your fellow comrades are now surviving through selling marijuana). May you visit Kadoma, what is it about Harare that keeps you glued?

We categorise this content as trolling. This is because it exposes the failure of the country's leadership to take care of its citizens. This kind of trolling (kusvereredza) refers to how in-laws call out a husband who fails to take care of his wife (huramu). This is also closely related to what usually happens at "nhimbe", where husbands or fathers who fail to properly care of their families are exposed without the troll suffering any adverse consequences. We argue that these two war veterans are using social media to mediate the same role that "huramu" and "nhimbe" did. \#ThisFlag also caught on with Zimbabweans in the diaspora, some of them well-known back home. For instance, popular musician Thomas Mapfumo recorded his own video, a flag wrapped around his neck, berating the government for betraying the promises of the liberation struggle. Mapfumo said:

Hello Zimbabweans, my name is Thomas Tafirenyika Mapfumo Muchadura. I am a musician sympathetic to the cause of the poor. Let me tell you that freedom isn't color of the skin of those governing but respect of rights such as press, association and assembly. Let's leave corruption and theft, what is happening in our country is hard, thugs have invaded our country. Some who are pretending to be revolutionaries are not working for the people for themselves. Our president is a dictator he is the chief architect of stealing state resources and people are suffering. Evan Mawarire is a brave man and we hope God will help him as we fight going forward.

This study categorises Mapfumo's message as both trolling and protest. This is because it seeks to svereredza (troll) the government for its failure and labelling of Mugabe as a dictator and not a liberator. Mapfumo is a well-known dissident musician and in this message, he sees a lot of \#ThisFlag echoed in his music. This suggests that Mapfumo has always been doing \#ThisFlag, but in his own way. The power of \#ThisFlag, in this case, was not just to rally Zimbabweans to the colours but also to make different Zimbabweans see themselves in the movement and to evaluate their 
contributions to a "new struggle" that started in 1980. What Mapfumo is saying also dovetails with the message above by the two war veterans from Kadoma, accentuating the sense that the disillusionment in Zimbabwe cut across political party lines. Perhaps a new national awakening was afoot? A follower named Farana De Agostini recorded a video calling on Zimbabweans to "sustain the momentum". With Henry Olonga's "My Zimbabwe" in the background, De Agostini, who appeared to be fighting back tears, said:

We are finally standing as one, ThisFlag has given us hope. Hope for a better Zimbabwe, hope to look after our families......I am sure every Zimbabwean has a story to tell...we want to live like decent people again. We don't want any more pain and suffering. I cry today because the pain is great, but I am inspired because we are now one across our racial and class divide.

We categorised De Agostini's message as call to action. This is because it details personal experience that has national resonance across race, class and ideological divide. The message is also laden with subtle political undertones to build a Zimbabwe which is colourless and classless. The conclusion that "we are now one" seems to be a new imaginary rather than something real. In 1980 Robert had used the same reconciliation imaginary to say that "we are one" across race, colour and creed. \#ThisFlag, however, implies that Mugabe had abandoned this dream of patriotic "oneness". Henry Olonga's "My Zimbabwe" further contests the ownership of Zimbabwe. Who is a patriot? Who is Zimbabwean?

\section{Conclusion}

The study found that social media has given Zimbabwe's unique digital activists the power, in real or illusory sense, to challenge narratives often advanced by post-colonial hegemonies. The use of the social media platforms throws power into disarray, while also mobilising citizens to interrogate the power and authority of elites, potentially decolonising the remnants of imperialism disguised as freedom. The use of social media by cyber-terrorists or dissidents helped those in the margins to reclaim citizen voices and spaces that traditional media typically filters out. Using social media to challenge the authority of a state accused of using tactics employed by colonial powers demonstrates the decolinising effect of digital technologies. More research has to be carried out to determine to social media's potential as a political tool for decolonisation. One might say that social media platforms offer a space and a voice perhaps in the same way that coffee houses and restaurants did during Habermas' days - but there is more to it when it comes to social media. As this chapter might have shown, dissidentiality quickly spread beyond 
leading actors, spills over to their followers, into the streets, people's homes and workplaces, into their metaphors and verbal art, and so on. Trolls, sceptical followers, blind followers, conspiracy theories peddlers and leakers all were thrown into the mix, creating a powder keg of talk, discourse, emotions, insults, praises, debate, provocation, carnival and engaged citizenship. Everyone touched by this web becomes, by extension, a social media dissident.

\section{References}

Banda, F., 2010. Citizen journalism \& democracy in Africa. An exploratory study. Grahamstown: Highway Africa, pp. 1-93.

Bodunrin, T. and Matsilele, T. Forthcoming. 'I am Tyler Perry, I endorse the \#EndSARS protest': An examination the use of parody accounts in the fight for social justice in Nigeria. In Reading Justice Claims on Social Media, edited by T. Matsilele. Cham: Palgrave Macmillan.

Bowler, Jr., G.M., 2010. Netnography: A method specifically designed to study cultures and communities online. The Qualitative Report 15(5), pp. 1270-1275.

Chitanana, T. and Mutsvairo, B., 2019. The deferred 'democracy dividend' of citizen journalism and social media: Perils, promises and prospects from the Zimbabwean experience. Westminster Papers in Communication and Culture 14(1), pp. 66-80. DOI: http://doi.org/10.16997/wpcc.305

Coleman, G., 2014. Hacker, hoaxer, whistleblower, spy: The many faces of Anonymous. London, UK: Verso books.

Fanon, F., 1966. The wretched of the earth (1st Evergreen ed.). New York: Grove Weidenfeld.

Gainous, J. and Wagner, K.M., 2013. Tweeting to power: The social media revolution in American politics. Oxford: Oxford University Press.

Gramsci, A., 1971. Selections from the Prison Notebooks, edited and translated by Q. Hoare and G. Nowell Smith. London: Lawrence \& Wishart.

Isaak, J. and Hanna, M.J., 2018. User data privacy: Facebook, Cambridge Analytica, and privacy protection. Computer 51(8), pp. 56-59.

Levitsky, S. and Way, L.A., 2010. Competitive authoritarianism: Hybrid regimes after the Cold War. Cambridge: Cambridge University Press.

LeBas, A., 2006. Polarization as craft: Party formation and state violence in Zimbabwe. Comparative Politics, pp. 419-438.

Mäkinen, M. and Wangu Kuira, M., 2008. Social media and postelection crisis in Kenya. The International Journal of Press/Politics 13(3), pp. 328-335.

Mare, A., 2014. Social media: The new protest drums in Southern Africa. In Pătruţ, Bogdan, and Monica Pătruț, eds. Social media in politics: case studies on the political power of social media. Vol. 13. (pp. 315-335). Cham: Springer.

Mare, A., 2016. Baba Jukwa and the digital repertoires of connective action in a 'Competitive Authoritarian Regime': The Case of Zimbabwe. In Digital activism in the social media era (pp. 45-68).Cham: Palgrave Macmillan.

Matsilele, T., 2019. Social media dissidence in Zimbabwe (Doctoral dissertation, University of Johannesburg).

Matsilele, T. and Ruhanya, P., 2021. Social media dissidence and activist resistance in Zimbabwe. Media, Culture \& Society, 43(2), pp. 381-394. 
Mhiripiri, N.A. and Mutsvairo, B., 2014. Social media, new ICTs and the challenges facing the Zimbabwe democratic process. In Crisis Management: Concepts, Methodologies, Tools, and Applications (pp. 1281-1301). IGI Global.

Mpofu, S., 2013. Social media and the politics of ethnicity in Zimbabwe. Ecquid Novi: African Journalism Studies 34(1), pp. 115-122.

Mpofu, S., 2015. When the subaltern speaks: Citizen journalism and genocide 'victims' voices online. African Journalism Studies 36(4), pp. 82-101.

Mpofu, S. and Matsilele, T., 2020. Social media and the concept of dissidence in Zimbabwean politics. In The History and Political Transition of Zimbabwe (pp. 221-243). Cham: Palgrave Macmillan.

Musarurwa, H.J., 2016. The rise of youth activism and non-violent action in addressing Zimbabwe's crisis. Conflict Trends 2016(3), pp. 50-56.

Mutsvairo, B. and Ronning, H., 2020. The Janus face of social media and democracy? Reflections on Africa. Media, Culture \& Society 42(3), pp. 317-328.

Mutsvairo, B. and Sirks, L., 2015. Examining the contribution of social media in advancing political participation in Zimbabwe. Journal of African Media Studies 7(3), pp. 329-344.

Smyth, T.N. and Best, M.L., 2013, December. Tweet to trust: Social media and elections in West Africa. In Proceedings of the sixth international conference on information and communication technologies and development: Full Papers-Volume 1 (pp. 133-141). Cape Town, South Africa: ACM.

Spivak, G.C., 1988. "Can the subaltern speak?" In Colonial discourse and postcolonial theory, edited by P. Williams and L. Chrisman (pp. 66-111). New York: Columbia University Press.

Tellis, W.M., 1997. Application of a case study methodology. The Qualitative Report 3(3), pp. 1-19.

Valenzuela, S., Park, N. and Kee, K.F., 2009. Is there social capital in a social network site?: Facebook use and college students' life satisfaction, trust, and participation. Journal of Computer-Mediated Communication 14(4), pp. 875-901.

Wasserman, H., 2011. Mobile phones, popular media, and everyday African democracy: Transmissions and transgressions. Popular Communication 9(2), pp. 146-158.

Zainal, Z., 2007. Case study as a research method. Jurnal Kemanusiaan 5(1). pp. 1-6.

Zeilig, L., 2016. Struggle reawakens in Zimbabwe. Green Left Weekly, 1103 (July 24), p. 15. 


\section{Part IV}

The media, the digital public sphere and decoloniality 

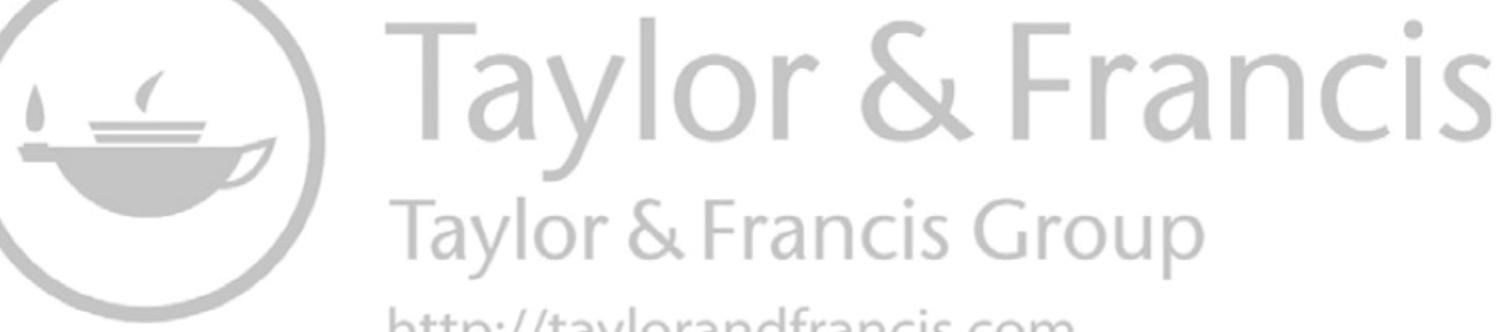

http://taylorandfrancis.com 


\title{
13 Transformation, fragmentation and decolonisation
}

\author{
The contested role of the media \\ in postcolonial South Africa
}

\author{
Ylva Rodny-Gumede
}

\section{Introduction}

Alongside global debates around the role of the news media amidst competition from social media and declining readership and faltering business models, debates in post-apartheid South Africa have foregrounded ideas of racial and gender equity in the newsroom as well as in the content of the news media. More recently, and emanating specifically from centres in the global South, these debates and concerns have shifted to focus on transformation that addresses colonial histories and legacies that shape the news media and the role that it should play in a changing political landscape.

Globally, the role of the news media is debated, and in an ever-evolving media industry it is heavily influenced by technological developments. With regard to the South African context, and with reference to transformation and decolonisation debates, it is important to note the contention that, amidst global shifts and technological changes, the news media and journalism has not changed much in terms of the role it assigns itself, and debates in and around the news media continue to be contested.

The most important public, as well as policy, debates in post-apartheid South Africa have concerned transformation in various sectors of society. Similarly, debates with regard to the news media have foregrounded ideas around transformation and issues have ranged from how to make the journalistic corps and news producers in general more equitable in terms of race and gender to the transformation of news content itself amidst criticism of racism and too narrow a focus on issues concerning only a small wealthy urban elite. As this range of priorities suggests, transformation in the media is a contested notion. And whereas equity in the workforce was high on the agenda in the first ten years of democracy, diversity in news content has emerged as higher on the priority list in the last 15 years, and this with a strong emphasis on access, in the first instance to mainstream media outlets and in later years, to new media platforms and social media.

More recently, debates and concerns have shifted to focus on transformation that runs deeper and that addresses colonial histories and legacies that shape the news media and the role that it should play in a changing 
political landscape characterised by renewed and amplified calls for a decolonisation of all sectors of society. With renewed calls for a speedier and deeper transformation and decolonisation of the media as presently enmeshed in, and expressed through, colonial legacies, it is clear that media transformation needs to be rethought in ways that talk less to the normative, idealist and long term, and instead to the real and experienced, in the present.

In this chapter, I revisit some of the debates around the role of the news media in South Africa. In doing so, I situate the South African news media in the postcolonial discourse and outline some of the contestations around social transformation, equity the political functions of the news media and journalism in contemporary society and in deepening democracy and democratic deliberation.

\section{Failures of social transformation}

Fundamental to understanding the decolonisation debate as it relates to the news media is an underlying failure of media transformation that springs from how social transformation as a whole tends to be a slow process in transitional societies and young democracies, let alone postcolonial societies. Studies of the news media in young democracies as well as transitional societies show that social transformation has often lagged behind political change and, as a result, the news media have also failed to transform. New institutions are formed on the remnants of the old and transformation can be lodged within a former authoritarian political system that is carried over and internalised by the new liberal democratic political dispensation (Downing 1996; O’Neil 1998; Sparks 2005, 2009; Sükösd 2000). This can be seen in the post-apartheid ANC-led governments' efforts to control the news media (Hadland 2007, 2012; Rozumilowicz 2002). The ways in which the ANC has tried to tighten its grip over the news media, including proposed new media legislation in South Africa, are indicative of this (Hadland 2007, 2012).

In addition, there are a range of demands put on the news media in postcolonial societies. Postcolonial societies stand apart from other transitional societies in the way in which the news media has been shaped by legacies of colonialism and, in the case of southern Africa, by apartheid and its aberrations. The legacies of colonialism and the continuous inequities it has created have made sure that state formation, politics and socio-economic development in the postcolony have remained premised on divisions of race (Rodny-Gumede 2020), and as Frassinelli (2018:4) states, 'race continues to be a marker of social difference, hierarchy and pain'. This, as Wasserman (2018:50) argues, also has implications for the news media on the continent and its audiences as reflected through 'the shared experience of a colonial subjection, struggles for independence and continued geopolitical and economic marginalization'. 
Added to this are the challenges posed by restructuring a liberation movement into a fully fledged democratic government and counter-tendencies of partisanship and co-option of the media. Postcolonial governments also face the challenge of developing a common sense of identity and sense of belonging and have often used the news media, particularly state broadcaster, for nation-building projects. In South Africa, as in many other postcolonial societies, there has for centuries existed a disjuncture between the state, on the one hand, and the diversity of ethnic, religious and language groups, on the other. The years after the first democratic elections ushered in an era of reconciliation and unity championed and represented by the late President Mandela. Under the banner of the "Rainbow nation", Mandela argued that boundaries between different population groups in South Africa should no longer have a bearing on state formation and social inclusion/exclusion in South Africa.

The notion of South Africa as a rainbow nation is, however, contested and seen by many as an artificial construct without grounding in reality (February and Jacobs 2010). And as much as Mandela has been lauded for being a proponent of racial unity, he has also been criticised for advocating for a superficial form of nation-building, concerned more with trying to dissipate white fears of a backlash against the state, and for over-emphasising a form of nation-building in which national insignia such as the new South African flag and the new multi-lingual national anthem took precedent over a deeper reconciliation and prevention of tribalism and cultural essentialism. In recent years, the ANC-led government has instead adopted a more nationalist rhetoric (Filatova 1997), and advocated for a more extensive and speedier process of racial transformation to address the inequities caused by widening wealth gaps post-apartheid (Marais 2011; Sparks 2003).

In South Africa, critics argue that the new democracy is being eroded by an all-powerful ANC (Duncan 2014), and, as in many postcolonial societies, the distinction between the state and the government has largely been eroded by former liberation movements who once in power have presided over one-party states with little or no opposition (Gumede 2012). Therefore, contestation over media development is linked to its coverage of the role of the state and political parties; as such, calls for reporting in the national interest are often conflated with the political party interest (Daniels 2012).

Looking beyond South Africa, there is a varied literature on the role of democracy in African countries: some African political leaders have alleged that there is authoritarianism implicit in African traditional values, and that the respect for liberty, independent thought and tolerance is allegedly only rooted in Western liberal culture (Tomaselli 2003). Some scholars have, however, rebutted this argument (Sen 1999; Tomaselli 2003). In the South African context though, Gumede $(2007,2012)$ argues that very few liberation movements put much effort into building relevant democratic institutions, so that the separation of powers, an independent judiciary and a system of checks and balances between branches of government are often just mere 
appendages. The failure to establish relevant democratic institutions and proper checks and balances has consequences for the structure of the media and the role the media can play in the new democracy. Horwitz (2001) therefore argues that the culture of secrecy and partisanship that often characterises liberation movements makes it difficult to support a non-partisan and non-adversarial press, even after the political struggle is over. Bennett (1998) argues that liberation movements generally arise from societies where there is little civic group structure or social capital and as a result, due to lack of civil and social organisation, many resistance movements fail to establish democratic governance structures. As a result of the absence of a legitimate civil society, the crucial phase of constructing democratic institutions is hindered by the lack of local social contexts and community forums in which to anchor and process political communication (Bennett 1998). South Africa however stands out in this regard where strong civil society organisations and coalitions, such as the Right to Know campaign and Save Public Broadcasting (SOS), have managed to keep the pressure up on government by opposing potentially restrictive legislation and have also lobbied for, and instigated transformation and diversification in the media (Sparks 2011).

This said, the new South African government has, since coming to power, adopted a largely market-friendly economic policy with the result that the media sector has been liberalised and de-regulated to a much higher extent than during the years of apartheid. This is a trend that many critics argue has led to increased commercialisation, "infotainment" and ownership concentration, at the expense of media diversity and pluralism and due to the increased sensitivity to commercial interests, it is argued that the South African media have not contributed to the democratic education of society to the extent that it could. There is thus tension between political control and market-driven changes and the media are caught in the contradiction between controls dictated by the new political establishment, on the one hand, and the market, on the other. And in the new South African democracy, elements of an old paternalistic, authoritarian system blend with more pluralist elements (Hadland 2012).

This said, the centrality of the news media to democratic processes, and in facilitating access to public discourse and civic engagement, is increasingly being questioned (Couldry 2009; Dahlgren and Sparks 1991; Rodny-Gumede 2017; Wasserman and Garman 2013). Research points to an increased fragmentation of the public sphere (Dahlgren 2005) as well as an increased audience disengagement within the traditional news media (World Association of Newspapers 2013), in particular with regard to younger audiences (Wasserman and Garman 2013). In many ways, scholars as well as scholarship have been divided into two camps of those who see the traditional news media as losing ground to new media outlets and platforms at the detriment of ensuring quality and trustworthiness of information disseminated in the public realm, vis-à-vis those who see the opportunities of the new media sphere for opening up opportunities for a diversity of views as 
well as facilitating access to a broader audience. The latter is important, and while much of the debate in the global North has focused on ideas around the changing media landscape and new challenges to journalism presented through new technology developments, new forms of audience interaction and participation and loss of editorial control, there are other issues that underline the development and fundamental ethos of the news media and journalism in transitional societies, and in particular postcolonial societies in the global South that talk to overcoming the many legacies of the past. One such issue, and the most important one, is how to make use of every means available to create a diverse and truly inclusive public sphere, as opposed to one still lodged in old conceptualisations of the audience as a small urban middle class.

All of this provides grounds for the continued contestations around the assumed role of the news media.

\section{The contested role of the news media}

In South Africa, as in many transitional societies, there is a prevailing political culture in which politicians are not accustomed to the open and scrutinising debate that is the characteristic of a democratic society, and hence they try to subordinate the media to their wishes. In South Africa, this can be seen in the ANC's attempts to control the public broadcaster, but also in their intolerance of critical voices in the print media. It also shows itself in the way that government has argued that the media should serve the national rather than the public interest. Black journalists and commentators, in particular, have come under pressure from government and have been accused of disloyalty for reporting on corruption and the failures of the ANC-led government.

Post-apartheid, many comparisons have been made between the present ANC-led government's treatment of the media and the old National Party's (NP) media policies (Brand 2008). Fourie and Oosthuizen (2001) state that the views of the ANC on South African and foreign media performance, and on media control and ownership have become increasingly like those of the NP government, accusing them of being unsupportive and unpatriotic and not contributing towards the development goals of government. Similarly, Johnston argues that the ANC's relationship with the press has been "distant and neurotically suspicious" at best, and "pathologically hostile" at worst (Johnston 2005). The uneasy relationship between the media and the government thus continues in the post-apartheid era. In very much the same manner as the NP criticised the white English-speaking press of being unpatriotic and spreading a false picture of South Africa abroad during the years of apartheid, the new government criticises the media for failing to take its responsibilities in a new South Africa. And much like the NP funded and controlled several media ventures, the ANC has advocated for a party-controlled media. Apart from increasing control over the SABC, 
the ANC was also been linked to the now defunct New Age, a newspaper launched in 2010 as a pro-ANC-government paper financed by business interests with links to former President Jacob Zuma (Benjamin 2010).

While government has criticised the news media for being untransformed, elitist and racist, and for looking at the world through "white" lenses, the news media itself argues that narrow policies of affirmative action based on race are fundamentally flawed and will have little or no impact on the standards or ethos of the news media and the role that the news media can play in a broader process of transformation and nation-building. Debates about national identity and the forging of national unity and how these debates play themselves out within the news media and in the role that it is assumed to perform are thus premised on tension between ideals of non-racialism, on the one hand, and African nationalists ideas and racialised politics that can serve divisionary agendas on the other (Marx 1998).

In later years, the mainstream Afrikaans- and English-speaking news media have often clashed with government over the role that media is assumed to play. The ANC-led government has often asked the news media to take a more developmental stance to journalism, urging journalists to be more supportive of the ruling party's policy agenda and achievements (Daniels 2012). At the same time, a large majority of South African journalists have emphasised their role as watchdogs of power, holding public officials accountable and exposing maladministration (Rodny-Gumede 2015b). This debate, as previously stated, has often been framed as whether the media should serve the "national interest", as mainly argued by government, or the "public interest", as generally maintained by the news media and journalists themselves (Wasserman and de Beer 2005).

In the main, and even if audiences have at times weighed in on debates, post-apartheid pressure against the mainstream press to transform has come predominantly from the ANC-led government. After the first democratic elections the press was perceived as being too white, and both former presidents, Mandela and Mbeki, were quite forthright in their critique of the media and the slow process of transformation (ANC 2007). Jacobs argues that it was not until leading ANC politicians, among these Mandela and Mbeki, started to "weigh-in" against the white face of the media that white media owners were convinced to undertake some kind of restructuring of ownership and control patterns (Jacobs 2007). However, Jacobs also argues that media owners probably initiated these changes 'for fear of government-imposed divestment or for fear of their business opportunities being obstructed in the new South Africa' (Jacobs 2007). Such pragmatic approaches to and motivations for transformation provide important context to the changing face of South Africa's news media.

Amidst the criticism levelled against the news media, the governing party has also at varying points in time suggested legislation to curb media freedom. Under the auspices of safeguarding pluralism in the media, the ANC has proposed a statutory Media Appeals Tribunal (MAT) (Berger 2010; 
Hadland 2007; Harber 2008; Wasserman 2010; Wasserman and de Beer 2006), including a new Protection of State Information Bill. The Bill known as the "Secrecy Bill" has the potential of making even the most inauspicious piece of government and state information classified and while passed in to legislation by Parliament already in 2013, former President Jacob Zuma as well as current President Cyril Ramaphosa has yet to sign it into law (deVos 2018). And while the ANC argues that media self-regulation has not been enough to ensure diversity and the protection of minority rights and interests in the media, critics argue that the suggested tribunal is less about the protection of rights than an attempt to muzzle the print media that so far have been difficult to co-opt, and that have kept up the pressure on government to deliver by scrutinising corruption in government and issues of non-performance (Daniels 2012).

What is lacking in this narrative, however, is the idea that, far from being co-opted by political powers, the South African news media have so far resisted attempts at coercion from government. Media houses, individual journalists, media advocacy groups and other civil society interest groups have lobbied and protested very successfully against threatening new media legislation. The suggested Media Appeals Tribunal (MAT), along with the proposed so-called "Secrecy Bill", has been discredited by activists, academics and the media fraternity, and is yet to be signed in to legislation.

And while the news media have in many ways resisted political influences and pressures, economic imperatives and the links between the new political power and the financial and economic elite have had implications for media ownership and control. This with consequences for how well the news media have been able to cover issues of public concern in relation to politics and power. Hence, when analysing the social, political and economic framework and how these have influenced the news media post-apartheid the picture that emerges is one of constant negotiation between structural constraints, imposed or not, real or perceived, and the agency and autonomy exercised by media houses, as well as individual journalists.

Even though the new 1996 South African Constitution guarantees the freedom of expression and the freedom of press, questions have been raised about new forms of censorship and ways of controlling the media post-apartheid South Africa. Lessons from comparative studies of media systems around the world have shown us that, more than anything else, the political environment shapes the organisation and structure of the media. And while media liberalisation and media freedom have been encouraged in the transition from a previously authoritarian political framework, the new leadership has found it hard to support an all too liberalised media and has employed various strategies to suppress them. The proposed new media legislation is indicative of this.

In later years, there have also been increased attacks on the news media from various public, as well as private individuals and the entities they represent. And instead of engaging in public debates around their grievances or 
taking cases to the Press Ombudsman, political parties and public officials are increasingly attacking journalists and editors through social media. In addition, journalists have been stalked and attacked outside their homes, and their properties have been destroyed (Rodny-Gumede 2019). A new threat against women journalists in particular has also emerged in the form of the cyber misogyny and attacks levelled at female journalist through social media (Rodny-Gumede 2019). ${ }^{1}$

In addition, key to understanding the renewed emphasis on decolonisation is understanding some of the failures in achieving equity in the organisation, workforce and content of the news media.

\section{Lack of equity in the news media}

After the first democratic elections in 1994, media transformation was high on the agenda, with a strong emphasis on transformation of the workforce. Since black people were excluded from the workforce for so long, a quick change of colour, in terms of both the workforce and the ownership of the media, became the main focus of attempts at transforming the news media post-apartheid. By creating equity in terms of race and gender, and to a lesser extent class, media content was thought to become more reflective of society at large. Affirmative action policies speak to a belief that social demographics of journalists do matter and if those who produce media content become more representative of society as a whole, diversity in media content will follow (Williams 2003: 105). As such, media policy debates have been heavily influenced by the broader affirmative action project that has informed transformation projects post-apartheid (Steenveld 2002). In the news media, affirmative action has contributed mainly to changes in ownership as well as newsroom staff where equity in terms of race and gender has been achieved (Lowe Morna 2018).

In particular, there have been changes at top management level in the news media. The proportion of white men in top management has gone down from $46 \%$ in 2006 to $14 \%$ in 2018 and for white women from $23 \%$ to $6 \%$ over the same period. However, the proportion of black men in top management in the media has more than doubled from $22 \%$ in 2006 to $50 \%$ in 2018. The proportion of black women in top management has gone up fivefold, from $6 \%$ in 2006 to $30 \%$ in 2018, but this is still 20 percentage points lower than for black men (Lowe Morna 2018: 37). Despite headways made, women still remain underrepresented in senior positions in the news media and at media company board level. And while, since 2009, there has been an increase in women's representation at senior and top management, this still falls short of the $50 \%$ mark. The proportion of women at board level has decreased from 38\% in 2009 to 19\% in 2018 (Lowe Morna 2018: 34).

However, research shows that the strong focus on racial equity in the newsroom has not been enough to create a news media that truly supports an inclusive participatory democracy and that gender equity in the workforce has 
not necessarily translated into a diversification of content (Rodny-Gumede 2015a, 2015b). Hence in later years, more focus has been put on the transformation and diversification of coverage and on reaching a broader audience and, in particular, on audiences previously excluded from the mainstream media (Rodny-Gumede 2015a, 2015b, 2015c). In addition, the need for journalists to be more cognisance of diverse audiences in terms of language, culture and socio-economic background has been raised (Rodny-Gumede 2015a). Research shows that journalists still feel circumscribed by race and gender (Rodny-Gumede 2015c). Interviews with South African journalists indicate that, on the one hand, there is a new awareness around race as well as gender developing among journalists and South African journalists are increasingly reflecting on their own background in relation to demographics such as race, class and gender and how this plays itself out in politics and social relations in South Africa (Rodny-Gumede 2015c). Media transformation debates have often highlighted that the broader public discourse shaped through the news media is still dominated by a narrow focus on the interest of a small white wealthy urban elite (Rodny-Gumede 2015a; Wasserman and DeBeer 2005; Wasserman and Garman 2013). This means that the voices of marginalised communities, largely those made up of women and children, seldom come through in media coverage (Rodny-Gumede 2015c).

Thus, higher equity in the workforce has not necessarily contributed to a broader transformation and diversification of media content and nor has actual editorial control improved equity in the newsroom. Research suggests that while more black people have taken up positions in the news media, giving them effectual operational control, this does not extend to allocative control in terms of having the power to hire and fire directors who fail to operate in the best interest of shareholders for example (Duncan 2011). And in terms of gender, equity has not been enough to make a broader impact on public discourses post-apartheid nor has it significantly contributed to widening access to the news media (Rodny-Gumede 2015a).

Of course, in later years, social media has gained importance and the rise of new media platforms and proliferation of social media has without a doubt been the most impactful transformation in the media sector as a whole in the last two decades. And political communication, as observed globally, has become more dependent on social media platforms and a new set of communicators as well as audience. The proliferation of social media platforms has fundamentally changed the way in which the news media interact with their audiences and ultimately the role that the news media play in a democracy - not to mention a nascent democracy and postcolonial society such as South Africa, where audiences are highly fragmented with large segments of the audience still cut off from the mainstream news media.

There are historical, cultural and political explanations as to how people understand and read the news media and how audiences are perceived and catered for. This extends to how the news media has historically served different segments of the audience and to a certain extent to how they continue 
to serve audiences in South Africa. Gone are the days of racist conceptualisations of the audience as reflected through "black editions" of newspapers and native or Bantustan news and newspapers overtly carrying an agenda of particular political ideologies and beliefs (Wasserman and de Beer 2005, 2006). However, the news media in South Africa is still fragmented and audiences are divided through socio-economic factors that dictate access and ideas around what is considered news. Language still fragments audiences and dictates the public interest of cultural groups in South Africa (Gassner 2007; Wasserman and de Beer 2005, 2006).

Access to the news media and public communications thus continues to be a problem even in the era of increased access to, as well as reliance on, social media.

\section{Conclusion}

This chapter has looked at how the South African news media have responded to the changes in the political and social environment postapartheid. Worldwide, the media are changing rapidly due to advances in technology and the media have also become much more global in scope and content. In South Africa, these changes are coupled with the political, social and cultural revolutions that have taken place in the country since the beginning of the 1990s. Yet, in spite of the tremendous changes that have taken place in the media since the end of apartheid, much still needs to be done in order for the news media to truly contribute to the strengthening and deepening of the nascent democracy.

The political environment has defined both the structures and the organisation of the news media, as well as the functions that journalists have been expected to perform. It shaped the role and conduct of the news media during apartheid, and has continued to do so after the dismantling of apartheid. The complex political environment has created a political culture that has defined policy formulation in South Africa, and has set the parameters for the role and conduct of the media and, ultimately, the content of that media. And, even though the end of apartheid has ushered in an era of new openness and willingness to transform the media, it has not automatically prevented government from trying to impose tighter state control. Nor has media independence brought with it the neutrality and non-partisanship many had hoped for. Old ways of conducting journalism and relating to the audience do not change that easily.

As both an agent for and site of transformation, the media were targeted in post-apartheid efforts to transform society at large. Foremost in these efforts was the formulation of affirmative action policies to employ more black and women journalists so as to rectify past discrimination. On the whole, these policies have been successful. However, there are still hurdles to be addressed. Race still informs much of the debates around the news media and there is still some way to go in order to increase women's participation, in particular, in shaping news agendas and in the extension broader public discourses. 
Racial transformation and policies of affirmative action are also highly contested. And while race remains an important variable to be factored into the discussion around media transformation, there is a need to move away from number games to more constructive debates around how to foster a new ethos for journalism and news coverage in post-apartheid South Africa.

It is clear that the decolonisation debate is premised on media transformation that remains uneven and a lack of consensus on what it should entail. Many unresolved issues remain in the media-politics nexus that keep influencing the structures, organisation and content of the news media as well as the role that the news media play in the postcolonial society. Many of the trends visible in the post-apartheid news media are not unique to South Africa. Similar trends have been observed in other transitional as well as postcolonial societies that, like South Africa, have undergone transitions from authoritarian regimes to capitalist liberal democracies. A cursory look at these transitions reveals that while there has been considerable political change, social transformation has often lagged behind and, as a result, the news media have also failed to transform.

While headways have been made in securing both racial and gender equity in the newsroom, issues around equity in news content and the role that the media can and should play in the new democratic society remain contested and critics argue that the broader public sphere remains the same as during the years of apartheid, reflecting old inequalities of access and power, and as such reflects the narrow political and economic transition that continues to unfold in South Africa (Jacobs 2007). This, independently of audiences accessing the traditional news media or newer digital and social media platforms.

And while much of the debate in the global North has focused on how to reinvent the news media to secure its future in the light of challenges posed by new technology influencing information dissemination and audience engagement, the news media in many postcolonial societies in the global South, South Africa included, will do better to re-affirm the role of the news media in democratic processes and democratic institution building and secure universal access.

\section{Note}

1 According to a 2018 world-wide study of female journalists by the International Women's Media Foundation more than half of the women journalists surveyed have suffered work-related abuse, threats or physical attacks (IWMF, 2018). Most worrying are the rising attacks on journalists that have emerged through social media, where female journalists are disproportionally targeted, in comparison to their male counterparts.

\section{References}

African National Congress (ANC). 2007. "Transformation of the media”, ANC Policy Discussion Document, March, 2007. 
Benjamin, C. 2010. Gupta group to fund 'ANC-sympathetic' newspaper. Available from: www.businessday.co.za/articles/Content.aspx?id=113830 (Accessed 15 January 2020).

Bennett, L. W. 1998. The media and democratic development. In P. O’Neil (Ed.), Communicating democracy: The media and political transitions (pp. 195-207). London: Lynne Rienner Publishers Inc.

Berger, G. 2010. Drop the media tribunal if you want a debate about the press. Available from: www.thoughtleader.co.za/guyberger/2010/08/16/drop-the-mediatribunal-if-you-want-debate-about-the-press (Accessed 12 January 2020).

Brand, R. 2008. The price of freedom: South Africa's media in 2008. Rhodes Journalism Review 28: 31.

Couldry, N. 2009. Does 'the media' have a future? European Journal of Communication 24(4): 437-449.

Dahlgren, P. 2005. The internet, public spheres, and political communication: Dispersion and deliberation. Political Communication 22: 147-162.

Dahlgren, P. \& Sparks, C. (Eds). 1991. Communication and citizenship - Journalism and the public sphere. London: Routledge.

Daniels, G. 2012. Fight for democracy: The ANC and the media in South Africa. Johannesburg: Wits University Press.

deVos, P. 2018. Why the failure of Presidents Zuma and Ramaphosa to deal with the Secrecy Bill is constitutionally delinquent. Available from: https://www. dailymaverick.co.za/opinionista/2018-07-19-why-the-failure-of-presidents-zumaand-ramaphosa-to-deal-with-the-secrecy-bill-is-constitutionally-delinquent/ (Accessed 15 January 2020).

Downing, J. 1996. Internationalizing media theory. London: Sage.

Duncan, J. 2014. The rise of the securocrats: The case of South Africa. Johannesburg: Jacana.

Duncan, J. 2011. South Africa: The print media dilemma. Available from: http:// allafrica.com/stories/printable/201103030841.html (Accessed on 15 January 2020).

February, J. \& Jacobs, S. 2010. If a country lives by its myths, then the myth of post-apartheid South Africa must be that it had become 'the rainbow nation'. Mail \& Guardian, 23 March. Available at: http://mg.co.za/article/2001-03-23madibas-magic-is-slowly-dissipating (accessed 15 January 2020).

Filatova, I. 1997. The rainbow against the African sky or African hegemony in a multi-cultural context? Transformation 34: 47-56.

Fourie, P. J. \& Oosthuizen, L. M. 2001. Media imperialism: The new world information and communication order. In P. J. Fourie (Ed.), Media Studies: Institutions, Theories and Issues (vol. 1, pp. 415-446). Cape Town, South Africa: Juta.

Frassinelli, P. P. 2018. Decolonisation: What it is and what research has to do with it. In K. G. Tomaselli (Ed.), Making Sense of Research (pp. 3-9). Pretoria: van Schaik Publishers.

Gassner, P. 2007. The end of the audience. How the nature of audiences changed. Global Media Journal-African Edition 1(1): 120-129.

Gumede, W. 2012. Restless nation: Making sense of troubled times. Cape Town, South Africa: Tafelberg.

Gumede, W. 2007. Democratic deficit: Africa's lost years. Speech delivered at The Basker Vashee Memorial Lecture, Transnational Institute, De Balie, Amsterdam, 15 June. 
Hadland, A. 2012. Africanizing three models of media and politics: The South African experience Adrian Hadland. In D. Hallin \& P. Mancini (Eds.), Comparing media systems beyond the Western world (pp. 96-118). London: Cambridge University Press.

Hadland, A. 2007. The South African print media 1994-2004: An application and critique of comparative media systems theory. $\mathrm{PhD}$ thesis University of Cape town, South Africa.

Harber, A. 2008. 2007 overview. Available from: http://www.theharbinger.co.za/ wordpress/2008/01/05/2007-overview (Accessed on 15 January 2020).

Horwitz, R. B. 2001. Communication and democratic reform in South Africa (p. 283). Cambridge: Cambridge University Press.

IWMF (International Women's Media Foundation). 2018. Violence and harassment against women in the news media: A global picture. Available from: (https:// www.iwmf.org/wp-content/uploads/2018/06/Violence-and-Harassment-againstWomen-in-the-News-Media.pdf). (Accessed 12 January 2020)

Jacobs, S. 2007. The media picture: Mapping the contemporary media scene in South Africa. In G. Gunnarsen, P. MacManus, M. Nielsen, \& H. E. Stolten (Eds.), At the end of the rainbow? Social identity and welfare state in the new South Africa (pp. 153-163). Copenhagen, Denmark: Africa Contact.

Johnston, A. 2005. The African National Congress, the print media and the development of mediated politics in South Africa. Critical Arts 19(1\&2): 12-35.

Lowe Morna, C. 2018. Glass ceiling: Women in South African news media. South Africa: GenderLinks.

Marais, H. 2011. South Africa pushed to the limit: The political economy of change. Cape Town: UCT Press.

Marx, A. W. 1998. Making race and nation: A comparison of South Africa, the United States, and Brazil. Cambridge: Cambridge University Press.

O’Neil, P. 1998. Democratization and mass communication. In Communicating democracy: the media and political transitions. Edited by O'Neil, P. London: Lynne Rienner Publishers Inc, pp.1-20.

Rodny-Gumede, Y. 2020. Expanding comparative media systems analysis from transitional to postcolonial societies, International Communication Gazette. Published online 23 January 2020.

Rodny-Gumede, Y. 2019. Cyberattacks on female journalists threaten everyone. Available from: https://mg.co.za/article/2019-03-06-cyberattacks-on-female-journaliststhreaten-everyone. Mail\&Guardian, 6 March. (Accessed 17 March 2020).

Rodny-Gumede, Y. 2017. Questioning the media-democracy relationship in view of the post-colony. Communication 43(2): 10-22.

Rodny-Gumede, Y. 2015a. An assessment of the public interest and ideas of the public in South Africa and the adoption of 'Ubuntu journalism'. Journal of Media Ethics 30(2): 109-124.

Rodny-Gumede, Y. 2015b. South African journalists' conceptualisation of professionalism and deviations form normative liberal values. Communicare 33(2): $54-69$.

Rodny-Gumede, Y. 2015c. Gender and public discourse formation in South Africa: Male and female journalists' influence on news agendas. Communication: South African Journal for Communication Theory and Research 41(2): 206-219. 
Rozumilowicz, B. 2002. Democratic change: A theoretical perspective. In M. E. Price \& B. Rozumilowicz \& S. Verhulst, Media reform: Democratizing the media, democratizing the state (pp. 9-26). London: Routledge.

Sen, A. 1999. Development as freedom. Oxford: Oxford University Press.

Sparks, A. 2003. Beyond the Miracle, Inside the New South Africa. Cape Town, South Africa: Jonathan Ball Publishers.

Sparks, C. 2011. South African media in a comparative perspective. Ecquid Novi: African Journalism Studies 32(2): 5-19.

Sparks, C. 2009. South African media in transition. Journal of African Media Studies 1(2): 195-220.

Sparks, C. 2005. Civil society as contested concept: Media and political transformation in Eastern Europe. In R. A. Hackett \& Y. Zhao (Eds.), Democratizing global media: One world, many struggles (pp. 37-56). Oxford: Rowman \& Littlefield Publishers Inc.

Steenveld, L. 2002. The South African national editors' forum and the independent newspapers' chair of media transformation (pp. 65-68). Grahamstown: Rhodes University.

Sükösd, M. 2000. Democratic transformation and the mass media in Hungary: From Stalinism to democratic consolidation. In R. Gunther \& A. Mughan (Eds.), Democracy and the media: A comparative perspective (pp. 122-164). Cambridge: Cambridge University Press.

Tomaselli, K. G. 2003. Our culture" vs "foreign culture", an essay on ontological and professional issues in African journalism. Gazette: International Journal for Communication Studies 65(6), pp. 427-441.

Wasserman, H. 2018. Media, geopolitics, and power: A view from the Global South. Cape Town: UCT Press.

Wasserman, H. 2010. Tabloid journalism in South Africa. Bloomington: Indiana University Press.

Wasserman, H. \& de Beer, A. S. 2006. Conflicts of interest? Debating the media's role in post-apartheid South Africa. In K. Voltmer (Ed.), Mass media and political communication in new democracies (pp. 59-75). London: Routledge.

Wasserman, H. \& De Beer, A. S. 2005. Which public? Whose interest? The South African media and its role during the first ten years of democracy. Critical Arts 19(1-2): 36-51.

Wasserman, H. \& Garman, A. 2013. The meanings of citizenship: Media use and democracy in South Africa. Social Dynamics: A Journal of African Studies 40(2): 392-407.

Williams, K. 2003. Understanding Media Theory. London: Arnold.

World Association of Newspapers and News publishers (WAN). 2013. World Press Trends: Print and Digital Together Increasing Newspaper Audiences. Available from http://www.wan-ifra.org/press-releases/2014/06/09/world-presstrends-print-and-digital-together-increasing-newspaper-audience (Accessed 2 March 2020). 


\title{
14 The voice of the voiceless? Decoloniality and online radical discourses in South Africa
}

\author{
Lorenzo Dalvit
}

\section{Introduction}

South Africa has one of the highest internet penetration rates on the African continent. Because of its history of political struggle, it has a vibrant civil society and a robust public debate. However, recent protests suggest that for a large portion of the population, public violence is still seen as an effective way to put issues on the national agenda. Digital media promises to revolutionise public debate by giving a "voice to the voiceless". By problematising which voices, who are the voiceless and why this is the case, this chapter problematises digital media and opens the discussion around the emergence of truly alternative voices and viewpoints. The nature of radical discourses within the digital public sphere is explored in relation to contentious issues rooted in historical processes, such as rape and farm murders. The approach is a decolonial one, concerned with bringing to light and interrogating the relations of power and cultural domination at play in constructing radical externality.

\section{Coloniality in South Africa}

South Africa combines one of the strongest economies on the African continent with one of the most unequal societies in the world. The country is still, to a large extent, shaped by Apartheid, which could be described as a form of colonialism (see Mbembe, 2001). Its legacy lingers on in what Quijano (2000) calls coloniality, expressed through coloniality of power, being and knowledge. Coloniality of power can be defined as the persistent form of discrimination and hegemonic domination inherited from the colonial system into subsequent social orders. Physical violence against members of marginalised groups provides countless examples, ranging from police brutality (Bruce, 2002) to violent crime (Demombynes and Özler, 2002) and domestic abuse (Jewkes, Levin and Penn-Kekana, 2002). A more subtle form of coloniality of power is expressed through structural violence (Christie, Wagner and Winter, 2001). A white privilege persists and "modern" ways of being are enforced through formal systems such as education (Soudien, 2010; Swartz, Arogundade and Davis, 2014) and through the increasing pervasiveness of datafication (see Arora, 2016).

DOI: $10.4324 / 9781003111962-14$ 
Coloniality of being refers to the systems of hierarchies between different ways of being in the world. The colonial encounter created the conditions to build on and extend patriarchal gender relationships to other attributes, first and foremost, race in the service of exploitation (Maldonado-Torres, 2007). The ability to categorise such socially constructed attributes and classify people accordingly is the quintessential mechanism of coloniality of being. Under Apartheid, such mechanism took the form of racial classification to support racial domination. In post-apartheid South Africa, racial and, to a lesser extent, gender classification persists with the intent to enable the redress of past injustices but, as warned against by Mignolo (2007), such redress appears to advantage a Black elite rather than the majority of the Black population (see Horwitz and Jain, 2011). As an example, at the time of writing, the COVID-19 pandemic is exposing deep structural inequalities in South African society and exacerbating the harsh living conditions of the most vulnerable portion of the population (see Graham, 2020; Manderson and Levine, 2020).

Coloniality of knowledge reflects the attribution of authoritative knowledge production to the metropole and of passive consumption to the periphery. As in other forms of coloniality, the goal is subordination and exploitation rather than annihilation, as exemplified by the harvesting of Indigenous knowledge about medicinal plants by the pharmaceutical industry (Mignolo, 2007; see also Green, 2012). In South Africa, coloniality of knowledge came into sharp focus during recent student protests calling for the decolonisation of the curriculum (Ndlovu, 2018). In the media, coloniality of knowledge is intimately linked with representation and voice (Chiumbu, 2016). Traditional media is often complicit in the cognitive injustice of representing members of marginalised groups as backward, irrational or unproductive (see Santos, 2012).

\section{Digital media and emancipation/liberation}

A decolonial perspective differentiates between emancipation and liberation. Mignolo (2007) defines the former as the efforts by members of local elites to contest hegemonic structures, but without challenging their terms of reference. According to Mignolo (2011), liberation can only be achieved through decoloniality as an analytical project, i.e. an act of epistemic disobedience challenging the very terms of reference imposed by modernity. Dahlberg (2007) notes how modern conceptions of online democracy are caught in a paradox of enabling freedom of expression while policing the boundaries of such freedom. He argues that an agonistic model of the digital public sphere accommodates the possibility of discursive radicalism, i.e. 'a systemic antagonism blocking the suturing of meaning, including the defining of 'legitimate' public sphere boundaries, and points to the possibility for successful contestation and re-articulation of discourse' (Dahlberg, 2007:54). The "radical" represents the irrational, extreme and absent 
"other" which cannot be given its own voice and serves to validate the dialectic between dominant and subordinate discourses. It also introduces a dynamic element by progressively pushing the boundaries of the digital public sphere, transforming it and radicalising it in the process. In this sense, the "radical" can be compared to the "constructively absent" postulated by de Sousa Santos (2012). However, in order to be epistemically disobedient in a decolonial sense, the goals of liberatory analysis are '(to detach) from [the modern] overall structure of knowledge in order to engage in an epistemic reconstitution' (E-International Relations, 2017:2). It is important to note that such analysis, while recognising and refuting canonical terms of reference as its starting point, does not entail a wholesale rejection of existing human knowledge, albeit produced in the West.

Globally, the promise by digital media to push the boundaries of public participation and give everybody a voice has been put under scrutiny. Morozov (2011) notes how repressive governments use the internet to spin propaganda, track activists and provide a way for their population to vent their frustration while preserving the status quo. Dean (2005) argues that democratic practices have been captured by the capitalist logic underpinning social media platforms, e.g. by reducing messages to contributions and by trapping users in endless arguments with no possibility of resolution in order to sustain the flow of data. While removing gatekeepers and allowing direct interaction between African politicians and their constituencies (Akinbobola, 2015), digital media has not freed democratic participation from the logics of accumulation, majoritarianism, expediency, etc. which constitute the "dark side" of modernity in the political domain. Emancipatory voices among the South African middle class saw in the internet an avenue to express their dissatisfaction (Glenn and Mettes, 2011). While these constituencies enjoy considerable economic power and cultural influence, their progressive potential is thwarted by their relatively small numbers at the ballot box compared to the rest of the population. As noted by Willems (2012), in many post-colonial societies anti-colonial movements continue, to a large extent, to perform the function of those civil society organisations that the disenfranchised masses do not have access to. Within the modern democratic dispensation, the ruling African National Congress (ANC) represents at the same time the state while exerting its influence on a significant portion of its natural counterpart, i.e. civil society. This may help to explain the apparent paradox of widespread criticism by township and rural dwellers of the political party they repeatedly voted into power. At the same time, for many middle and working class South Africans political participation (online and otherwise) is reduced to spectacle or ritual (e.g. sharing "thumbies", i.e. images of one's thumb tinted by the black ink used to avoid multiple voting during elections) on social media (see Chunylall, 2016).

Digital and mobile media provide new avenues for the perspectives, experiences and practices of members of marginalised groups to come to the fore (Wasserman, 2011). At the same time, the inequalities which characterise 
South African society are reflected online. While approximately $64 \%$ of the population is connected to the internet, this is largely due to widespread mobile penetration (Statista, 2020). For most South Africans from a marginalised background, the online experience is often mobile-first, mobile-centric and mobile-only (see Walton and Leukes, 2013). In a country characterised by endemic poverty, where a large portion of the population relies on social grants as its main source of income, this presents particular constraints. The possibility to participate online in public discussion, while nominally high, is in actual fact limited by the cost of data and network coverage. Research suggests that online interactions for a wide portion of the population take place via instant messaging, which is seen as a cheap alternative to voice calls and SMS (We are Social, 2019). Active participation on social media platforms such as Facebook and Twitter, while one of the highest on the continent, is at approximately $42 \%$ and $19 \%$ respectively (Statcounter, 2020). Adding to the fragmentation of the online public sphere is linguistic diversity coupled with relatively low levels of English proficiency (see Salawu, 2018).

\section{The pursuit of a radical voice online}

From the methodological point of view, the analysis of discourse from a decolonial perspective presents a number of challenges. Resende (2018) notes the colonial influence of scholars such as Faircloth and Foucault on scholarship in the field. She argues for decolonisation at the level of theory and method, problematising the supposed universality of knowledge and appraising local epistemological creativity. In particular, she puts forward an argument for 'decolonizing the being, making strategic use of this paradoxical space, which contains the possibilities of knowledge communion, also including common knowledge' (Resende, 2018:1). The researcher is required to distance him- or herself from a universal conception of "truth" and reflexively interrogate its collective historical construction within the subordinated condition of pain and suffering resulting from coloniality (see Passada, 2019). In this chapter, I focus on online discourses as epistemological potential in terms of gender and sexuality as well as race and class.

Consistent with a decolonial approach, I seek to avoid extractive methodologies (see Santos, 2016) as much as possible. I rely on freely available online publications and, when accessible, user comments. While it could be argued that social media material is by its very nature extractive and exploitative (see dean, 2005; Couldry and Mejias, 2019), I rely on such material in so far as it can be freely accessed online without the need to register or subscribe to any platform. This excludes some potentially relevant content on Facebook or WhatsApp but leaves major forums such as those on Twitter and YouTube open. It should be noted that these are still relatively elite platforms (see Dlamini et al., 2018), as is the consumption of online publications, which inevitably introduces a first bias as to who the "voiceless" 
are. A second and interrelated bias is represented by limiting my analysis to content in English. Despite the dominant role of English, South Africa's multilingual character is reflected online (Salawu, 2018). Precisely because of its crucial importance, a comparative analysis including speakers of different languages deserves a separate and dedicated publication by authors fully proficient in such languages.

\section{Gender and sexuality}

South Africa is characterised by high levels of rape and of gender-based violence. Buiten and Naidoo (2016) highlight the relationship between these and race, class and other socio-economic factors, as well as their historical roots. Gender inequalities are recognised as a key area by policy makers (Meyiwa, Williamson, Maseti and Ntabanyane, 2017) and civil society organisations (Connolly, 2017). August is women's month in South Africa, providing a space for gender issues to feature prominently in the media (Moletsane, 2019). Such efforts are complemented by online campaigns such as the international \#MeToo (Mendes, Ringrose and Keller, 2018) and the local \#MenAreTrash (Samaga, 2017; Tanaka, 2019). The \#AmINext trended on Twitter after a specific incident catalysed public discussion. On $24 \mathrm{Au}-$ gust 2019, a 19-year-old university student was lured to a post office after hours, raped and killed by an employee (Independent Online, 2019). The ensuing online and social media outpour outlines two aspects relevant to our discussion, i.e. the discursive construction of the subjects involved and of gender-based violence.

The victim was a young and attractive member of the Black middle class and a student at a prestigious university. While comments such as "She is any of us. We feel helpless and scared"(@Hlehle_Lupindo,2 September 2019) imply a common condition of suffering on the basis of gender, decolonial scholars such as Dietze (2014) emphasise the importance of an intersectional approach, taking race, class and socio-economic background into account. Inequalities in (digital) media representation and government response are acknowledged by calls such as 'Can government, media and civil society give the same attention and love to other victims of sexual violence like they are giving to [her]. In this world if you are poor, your life does not matter' @,AdvoBarryRoux, 7 September 2019). The latter part of the tweet also illustrates how, in deSousa-Santos' (2012:53) words, 'Non-existence is produced whenever a certain entity is considered invisible, non-intelligible or discardable'. In the statement, 'But statistics show us that its the people we trust, the people who are close to us. rarely strangers [...] When last did $u$ see girls trending cos a blesser raped and killed them?' (@blaqdayimane, 18 October 2019). The reference to intimate relationships and "blessers" points towards the reality of many young women from a poor background who experience violence within a context of emotional dependency and/or economic deprivation (see Varjavandi, 2017). 
Online responses highlight other dimensions of difference while reaffirming a common experience of oppression. Examples such as 'Women get murdered literally everyday but people (Tweeps) get raged ONLY when it's a 'pretty', most of the time, light skinned women (sometimes with a Lil social influence) that gets to make the news'(@Amini_Kay, 8 September 2019) suggest the persistence of patriarchal and colonial prejudice, valuing women on account of their beauty in accordance with Western canons (see Bizela, 2016). In the tweet

\#bringNenehome thing has nothing do with the fact that [...] is popular or pretty or whatever you weirdos keep assuming. It has EVERYTHING to do with the fact that she is a young black woman and thus is extremely vulnerable. Any sane person would sympathize.

(@Libo_Ngwenya, 27 August 2019)

Ngwenya (2019) reaffirms a shared condition of suffering in relation to patriarchy and colonialism (see Christian, 1987) while appealing to "modern" concepts such as rationality which Mignolo (2007:451) regards as an 'engulfing and at the same time defensive and exclusionary' mean of emancipation.

Once identified, the perpetrator's house was burnt down by an angry mob and he was sentenced to life in jail. Conviction rates for rape and femicide are low and public/community justice is not uncommon in South Africa (see Singh, 2005; Comaroff, 2007). Some comments on Twitter advocated for the same to be done to the alleged perpetrator (@Rori_orr, 2019; @iloveretha, 2019; @zanelecele, 2019) with few critical reflections such as 'What if it turns out that, thats not his house?' (@be_kak,4 September 2019) and 'That for me, is another branch of mob justice' (@esihlel, 16 September 2019). References to the struggle against Apartheid were evident in calls for the practice of necklacing used by black communities to deal with spies and traitors (@Gaido Kb, 2019), in invoking divine justice reflecting the prominent role of churches as CSOs (@mabelanneko, 2019) and in calling for the antiApartheid strategy of 'making the country ungovernable' (@YMaqalekane, 2019) on Twitter. The latter was echoed in online media with provocative statements such as 'We must rage, we must give voice to our rage... we must march, we must burn things, we must express our collective rage. Men do all the time' (Thamm, 28 August 2019). The grewsome details of the case (see Nombembe, 15 August 2019) appear to justify such "suspension of ethics" (see Gordon, 2007) which Maldonado-Torres (2007) identifies as instrumental in the "naturalisation of the un-ethics of war" as an expression of the coloniality of being.

Besides advocating for extrajudicial punishment and public violence, arguably some of the worse enduring legacies of their shared troubled past, South Africans used digital media to open a conversation about reintroducing the death penalty abolished at the end of Apartheid. This provides an example of 'inter-subjectively produced 'public' reasons of those affected by 
particular issues' which Dahlberg (2007:48) identifies as a feature of online deliberative democracy. A petition on change.org (2019) highlights loss of faith in the effectiveness of the justice system (e.g. 'Enough is enough! We are being raped, killed and tortured every day and the perpetrators always roam free or get a lighter sentence. It's time to teach them a proper lesson and not allow them back into society!') as well as in political parties (@ Lukhanyo_Journ0, 2 September 2019), although some opposition parties took a favourable position. Somewhat paradoxically, the reintroduction of the death penalty was linked to the struggle against Apartheid as evident in claims such as 'This is not the South Africa our beloved struggle stalwarts fought for' (@GiftSmith_ZA,2 September 2019) and to human rights in a constitutional democracy as shown by @ThatoMo97 (2 September, 2019), who argues that 'The end of the death penalty by @,ConCourtSA was reasoned as a, cruel, inhuman and degrading punishment'. - The Constitution. Is rape \& murder not a, "cruel, inhuman and degrading punishment." FOR SIMPLY BEING A WOMAN IN SOUTH AFRICA?". The human rights discourse, critiqued by prominent decolonial scholars such as MaldonadoTorres (2017), is used by men to distance themselves from the issue as shown by some comments in online forums such as \#NotAllMen (see Hayes and Luther, 2018; Nicholas and Agius, 2018). As noted by Sanger (2019), there is a risk of reproducing colonial modes of thinking in racially and socioeconomically profiling criminals, thus supporting the construction of a barbaric, irrational, deviant "other" against whom anger can be legitimately expressed.

\section{Race and class}

South Africa's past of institutionalised racism and ethnic segregation is well documented (see Maylam, 2017). Despite attempts by the media to portray a non-racial society, race relations are still a contentious issue in political communication (see Dladla, 2017; Gottschalk, 2019). Videos documenting racist incidents are often shot with a mobile phone and posted on YouTube (Multimedia LIVE, 2017; SABC Digital News, 2018a, 2018b). Incidents of white middle-class South Africans posting racist remarks on social media attracted considerable public attention and resulted in convictions on the grounds of racism (Seleka and Grobler, 2020; Parez-Pena, 2018; Wicks, 2019). Beyond derogatory slur, several examples of racially motivated physical violence of whites against blacks (sometimes posted by the perpetrators themselves on YouTube) received media attention (see Keane, 2018).

On 30 November 2019, a Black traditional healer and his family were held hostage and he was eventually killed by a white farm owner, who was later shot by the intervening police (News24, 2019). A video posted on YouTube (LuiSpot, 2019) shows a white man shouting and terrorising a black family with a stick before budging the man to death. Anti-ANC, militaristic and messianic rants in the video are reminiscent of radical right-wing politics 
and religious fervour associated with Afrikaner nationalism under Apartheid (see Patterson, 1977; Vuuren, 2005). News articles available online (The Citizen, 2019; SABC Digital News, 2019) as well as many user comments attributed the attack to mental instability consistent with attempts to downplay racism (particularly by white Afrikaners) in the media (see Wasserman, 2010). In fact, comments such as 'This man was clearly mentally ill. Such a sad situation. Now this whole country is gonna hate on each other again cause of this' (Lisa Marie, 2019) highlight the potential for this incident to be politicised and re-ignite racial tensions. Resentment on the part of some users is evident in replies to the latter comment, such as 'So a white kills a Blackman like these and you blame mental sicknss, I think you are sick yourself' (CS DR, 2019), 'Maybe you are sick together, how can u come here defend a white criminal=' (Pumelele Mahlombe, 2019) as well as comments to related videos (Multimedia LIVE, 2019), such as 'My question is, if it was mental health illness why did he not chose one of his white friend???' (Peter Ncube, 2019). By contesting modern individualistic models of mental illness, coloniality of disability (Dirth and Adams, 2019) provides a tool to "normalise" and, at the same time, contextualise deviant behaviour such as the one depicted in the video within socio-historical processes. On the one hand, this suggests the use of mental illness to explain violent and irrational behaviour by a member of the "civilised" group, a practice seldom employed with colonised subjects. On the other hand, it exposes the reduction of the perpetrator to a member of a subaltern group (the disabled) possibly as an attempt to preserve the link between moral superiority and racial identity.

This incident is significant in terms of the mediatised construction of the subjects involved as well as its timing. The victim was a traditional healer, suggesting an association with superstition, backwardness and inferiority. Santos (2012:52) notes how the logic of linear time 'produces non-existence by describing as backward whatever is asymmetrical vis-à-vis whatever is declared forward'. Some users like Rechardo Fritz (2019) even believed that eradicating such backwardness was the motive, as suggested by the claim that 'people recording killings of Black people because they are traditional HEALERS...that is not on!', the perpetrator was allegedly his friend and a trainee sangoma (i.e. traditional healer) himself. Emphasis on this point in the media (often alongside allegations of a history of violent behaviour) (Dayimani, 2019; Head, 2019a, 2019b) supports the "othering" process of subalternisation noted above with respect to disability and expressed by comments such as 'He was a white Sangoma (witch doctor) and affiliated with the ANC! Definitely not a FARMER, typical african propaganda like usual!' (AQW, 2019) and '[the perpetrator] is NOT white' (lauqe rianne, 2019). Replies to the latter comment, i.e. 'may he rest in peace, may all white racists die a horrible death' (Z D, 2019), reaffirm a radical and violent stance against the perpetrator as representative of all colonising subjects. The video was published shortly after South Africa won the 2019 Rugby World Cup, amidst racial controversies (Kiewit, 2019) motivated by the long-standing 
association of rugby with white nationalism (see Tembo, 2019). Comments such as 'EFF highlighted that this cook wore a springboks jersey..really... what is the end goal in that though' (C2de G, 2019) point to a possible indication of racism. This point was picked up by opposition politicians who decried the relatively limited coverage of the story by news outlets as an example of white privilege (Head, 2019a, 2019b) in the official statement:

All major news outlets should be leading with this anti-black farm murder committed by a white, racist, Springbok t-shirt-wearing man. People will find this hard to accept, they will live in denial and the false euphoria created by the very politics of the Springbok t-shirt worn by the anti-black perpetrator.

(Ndlozi, 2019)

The reference to a farm murder above resonates with a narrative of white genocide which gained media coverage nationally and internationally, as shown by comments such as '@CS DR blacks go around slaughtering white farmers all the time. Your silence about it is deafening' [reply to a comment in the YouTube video]. While most victims of violent crime are Black (see Bearak, 2010), violence against whites and in particular farmers gained national and international resonance (Ward, 2018; Williams, 2018; vpro documentary, 2019). Comments to a right-wing documentary Farmlands provide examples of racism 'In 20 years [Blacks] they're going to be starving to death because of their policies. Somehow they'll find a way to blame white people for that too' (AdamIowa88, 2019) and praise for the Apartheid and colonial past as in 'South Africa is now ten times worse than it was back in the 1980s before the end of aparthied' (Angus Meigh, 2019) and '@Fatou soumare You would be nothing without white people. What did you do in africa? You didn't even have a written language or nothing' (St. Simon of Trent, 2019) which resonate with a tweet by an opposition politician which sparked considerable public debate (Nkanjeni, 2019) and with Mignolo's (2007:453) assertion that 'modernity appears when Europe affirms itself as the "center" of a World History that it inaugurates'. Drawing on the powerful discourse of minority and human rights, the CSO Afriforum lobbied for the recognition of refugee status for farmers migrating from South Africa to Australia (Taylor, 2018). Consistent with an othering strategy, Afriforum warned against referring to the perpetrator in the incident discussed above as a "farmer" (The Citizen, 2019).

Farmlands are sites of intense ideological struggle as well as mediatise physical violence. For historical reasons, race is inextricably linked to class in South Africa, with unequal distribution of arable land as a case in point (see Keane, 2018). In the aftermath of the incident discussed above, the opposition party EFF organised the occupation of the perpetrator's farm with the intention of converting it into a preschool (The Citizen, 2019). The old South African flag, allegedly found on the premises, is banned from 
gratuitous public display as a symbol of white supremacy and racial oppression (Bernstein and Lopes, 2019), fuelling calls for the expropriation of the property without compensation (Baloyi, 2020). While actual land reform yielded mixed results, the prospect of taking land away from white farmers perceived to have benefitted unfairly from past policies holds political appeal as an instrument of social justice for some, while fuelling fears of reverse racism for others.

\section{Reflections and conclusions}

The two examples discussed in this chapter are by no means representative of the whole spectrum of issues pertaining to gender, race and/or class in South Africa. Stories of corrective rape of lesbian black women, xenophobic attacks against foreigners from other African countries, police brutality against street vendors, etc. may provide a better representation of the lived experiences of marginalised subjects. However, the very resonance of the two incidents with a number of ongoing public discussions can be read as an indication of coloniality. These two stories provide intelligible representations of rape and murder within a Western patriarchal and colonial trope (e.g. an older male stranger deceiving and violently assaulting a younger unsuspecting woman, a deranged white man budging a meek black friend to death). Public outrage about such incidents diverts attention from less visible but more pervasive aspects of domination, such as institutional sexism and racism, and from more localised (but not less real) conditions of oppression. By constructing the perpetrators as deviant outcasts, online discussions preserve rather than challenge hierarchical structures and the underlying dichotomies (men/ women, black/white, rich/poor), as well as legitimising violence. Radical positions such as burning rapists alive or killing white racists do not represent epistemic disobedience, but rather compliance with a logic of suspended ethics central to the colonial project. Aspects of patriarchal and colonial discourses such as victim blaming, though present in both cases, were not considered here as they are not particularly relevant to political communication.

\section{References}

@ AdvoBarryRoux. (2019). Can government, media and civil society give the same attention and love to other victims of sexual violence like they are giving to [...]. [Twitter]. 7 September. [Accessed 12/04/2020]. Available from: https://twitter.com/ AdvoBarryRoux/status/1170286282473390081

@,Amini_Kay. (2019). Women get murdered literally everyday but people(Tweeps) get raged ONLY when it's a "pretty" [...]. [Twitter] 8 September. [Accessed 12/04/2020]. Available from: https://twitter.com/Amini_Kay/status/1170649750082863104

@be_kak. (2019). What if it turns out that, thats not his house? [Twitter]. 4 September. [Accessed 12/04/2020]. Available from: https://twitter.com/be_kak/ status/1169155614959947778 
@ blaqdayimane. (2019). But statistics show us that its the people we trust, the people who are close to us. rarely strangers [...]. [Twitter]. 18 October. [Accessed 12/04/2020]. Available from: https://twitter.com/blaqdayimane/status/11851022 88681132032

@esihlel. (2019). That for me, is another branch of mob justice. [Twitter]. 16 September. [Accessed 12/04/2020]. Available from: https://twitter.com/EsihleL/ status/1173361638919069696

@Gaido_Kb. (2019). Now he must be necklaced. [Twitter]. 3 September. [Accessed 12/04/2020]. Available from: https://twitter.com/Gaido_Kb/status/116896 9244417155073

@GiftSmith_ZA. (2019). Death penalty should be re-instated. Women are living in fear. [Twitter]. 2 September. [Accessed 12/04/2020]. Available at: https://twitter. com/GiftSmith_ZA/status/1168500347914072065

@ Hlehle_Lupindo. (2019). She is any of us. We feel helpless and scared [Twitter]. 2 September. [Accessed 12/04/2020]. Available from: https://twitter.com/ Hlehle_Lupindo/status/1168562917572317184

@iloverethe. (2019). Luyanda Botha's house is currently being burnt to ashes by abantu base Khayelitsha [...]. [Twitter]. 3 September. [Accessed 12/04/2020]. Available from: https://twitter.com/iloveretha/status/1168940555360976896

@Libo_Ngwenya. (2019). It has EVERYTHING to do with the fact that she is a young black woman and thus is extremely vulnerable [...]. [Twitter]. 27 August. [Accessed 12/04/2020]. Available from: https://twitter.com/Libo_Ngwenya/ status/1166381160387272704

@_Lukhanyo_Journ0. (2019). What kinda society is SouthAfrica? NONE of this country's political parties have the death penalty in their policies [...]. [Twitter]. 2 September. [Accessed 12/04/2020]. Available from: https://twitter.com/ Lukhanyo_Journ0/status/1168579372758065154

@ mabelanneko. (2019). Yall are doing the Lord's work. [Twitter] 3 September. [Accessed 12/04/2020]. Available from: https://twitter.com/mabelanneko/ status/1168963422878347267

@ Rori_orr. (2019). He should've been inside. [Twitter]. 3 September. [Accessed 12/04/2020]. Available from: https://twitter.com/Rori_orr/status/11689 47005596602368

@ ThatoMo97. (2019). The end of the death penalty by @ConCourtSA was reasoned as a, "cruel, inhuman and degrading punishment" [...]. [Twitter]. 2 September. [Accessed 12/04/2020]. Available from: https://twitter.com/ThatoMo97/ status/1168564801771098113

@)YMaqalekane. (2019). We must bring back the death penalty and to do so we as citizens must shut down South Africa! [Twitter]. 3 September. [Accessed 12/04/2020]. Available from: https://twitter.com/YMaqalekane/status/1168504326551158784

(a)zanelecele. (2019). They should locked the doors first and burned him alive. [Twitter]. 3 September. [Accessed 12/04/2020]. Available from: https://twitter.com/ zanelecele/status/1168965191771537410

AdamIowa88. (2019) Re: FARMLANDS (2018) | Official Documentary. [Video file]. Retrieved from https://www.youtube.com/watch?v=a_bDc7FfItk\&t=16s

Akinbobola, Y. (2015). Theorising the African digital public sphere: A West African odyssey. African Journalism Studies, 36(4), pp. 47-65.

AQW. (2019) Re: SA reacts to Anele Hoyana's murder. [Video file]. Retrieved from https://www.youtube.com/watch?v=gP1GFyg3_fI 
Arora, P. (2016). Bottom of the data pyramid: Big data and the global south. International Journal of Communication, 10(19), pp. 81-99.

Baloyi, T. (2020). 'Land expropriation: Deadline to amend Constitution extended... again' The South African, 7 March 2020. Available at: https://www. thesouthafrican.com/news/land-expropriation-deadline-extended-may-2020/ [Accessed 12/04/2020]

Bearak, B., 2009. Constant fear and mob rule in South Africa slum. New York Times, 29, June 2009. Available at: https://www.nytimes.com/2009/06/30/world/ africa/30safrica.html [Accessed 12/04/2020]

Bernstein, D. and Lopes, R. (2019). "Never Again"-the old South African flag case: Spotlight on pro bono. Without Prejudice, 19(10), pp. 14-15.

Bizela, S. (2016). Post-Fanonian or not? The 'yellow bone' factor and re-writing blackness in popular culture. WritingThreeSixty, 2(2), pp. 27-42.

Bruce, D. (2002). Police brutality in South Africa. From the report Police Brutality in Southern Africa-A Human Rights Perspective, edited by N. Mwanajiti, P. Mhlanga, M. Sifuniso, Y. Nachali-Kambikambi, M. Muuba and M. Mwananyanda. Inter-African Network for Human Rights and Development (Afronet). Available at: https://www.csvr.org.za/docs/policing/policebrutality.pdf

Buiten, D. and Naidoo, K. (2016). Framing the problem of rape in South Africa: Gender, race, class and state histories. Current Sociology, 64(4), pp. 535-550.

C2de G. (2019) Re: SA reacts to Anele Hoyana's murder. [Video file].Retrieved from https://www.youtube.com/watch?v=gPlGFyg3_fI

Change.org. (2020). Bring back the death sentence in SA for crimes against women. Retrieved online from: https://www.change.org/p/south-african-governmentbring-back-the-death-sentence-in-sa-for-crimes-against-women

Chiumbu, S. (2016). Media, race and capital: A decolonial analysis of representation of miners' strikes in South Africa. African Studies, 75(3), pp. 417-435.

Christie, D. J., Wagner, R. V., and Winter, D. A. (Eds.). (2001). Peace, Conflict, and Violence: Peace Psychology for the 21st Century. Englewood Cliffs, New Jersey: Prentice-Hall.

Chunylall, R. (2016). \# Democracy: A case study of social media use amongst members of the public sphere during the 2014 South African general election (Doctoral dissertation).

Citizen Reporter. (2019). 'EFF invade Fritz 'Majeke' Joubert's smallholding, 'discover old SA flag”' The Citizen, 4 December 2019. Available at: https://citizen.co.za/ news/south-africa/crime/2214632/eff-invade-fritz-majeke-jouberts-smallholdingdiscover-old-sa-flag/ [Accessed 12/04/2020]

Comaroff, J. and Comaroff, J. (2007). Popular justice in the new South Africa: Policing the boundaries of freedom. Legitimacy and criminal justice: International perspectives. New York: Russell Sage Foundation, pp. 215-238.

Connolly, S. (2017). Assessing the successes of and challenges facing civil society organizations in South Africa, in influencing gender-based violence policy. Independent Study Project (ISP) collection. Available from: https://digitalcollections. sit.edu/isp_collection/2697

Couldry, N. and Mejias, U. A. (2019). Data colonialism: Rethinking big data's relation to the contemporary subject. Television \& New Media, 20(4), pp. 336-349.

CS DR. (2019) Re: Anele Hoyana murder | Busisiwe Jemsana-Mantashe speaks to SAPS officials. [Video file].Retrieved from https://www.youtube.com/watch? $v=$ aOWI2VCNVuk 
Dahlberg, L. (2007). The Internet, deliberative democracy, and power: Radicalizing the public sphere. International Journal of Media \& Cultural Politics, 3(1), pp. $47-64$.

Dayimani, M. (2019). 'Sangoma killer Fritz Joubert was fired from police 'after too many deaths', Timeslive, 5 December 2019. Available at: https://www.timeslive. co.za/news/south-africa/2019-12-05-sangoma-killer-fritz-joubert-was-fired-frompolice-after-too-many-deaths/ [Accessed 13/04/2020]

Dean, J. (2005). Communicative capitalism: Circulation and the foreclosure of politics. Cultural Politics, 1(1), pp. 51-74.

Dietze, G. (2014). Decolonizing gender-Gendering decolonial theory: Crosscurrents and archaeologies. In Decoloniality, Postcoloniality, Black Critique: Joints and Fissures, 245-69.

Dirth, T. P. and Adams, G. A. (2019). Decolonial theory and disability studies: On the modernity/coloniality of ability. Journal of Social and Political Psychology, 7(1), pp. 260-289.

Dladla, N. (2017). Racism and the marginality of African philosophy in South Africa. Phronimon, 18(1), pp. 204-231.

Dlamini, Z., Malinga, L., Masiane, T. and Tshiololi, M. (2018). Social media advocacy in the\# MustFall campaigns in South Africa. In A. Josang (Ed). ECCWS 2018 17th European Conference on Cyber Warfare and Security V2 (p. 120). Oslo: Academic Conferences and publishing limited.

E-International Relations. (2017). Interview_-Walter Mignolo Part 2. 21 January 2017. Available at: https://www.e-ir.info/2017/01/21/interview-walter-mignolopart-2key-concepts/

Etheridge, J. (2019). 'East London man who killed friend and held his children hostage shot dead on farm', News24, 02 December 2019. Available at: https://www. news24.com/SouthAfrica/News/east-london-man-who-killed-friend-and-heldhis-children-hostage-shot-dead-on-farm-20191202 [Accessed 13/04/2020]

Fritz. (2019) Re: SA reacts to Anele Hoyana's murder. [Video file].Retrieved from https://www.youtube.com/watch?v=gP1GFyg3_fI

Glenn, I. and Mattes, R. (2011). Political communication in post-apartheid South Africa. The Sage Handbook of Political Communication. London: Sage Publications.

Gordon, L. (2007). Problematic People and Epistemic Decolonization. Postcolonialism and Political Theory (p. 121).

Gottschalk, K. (2019). 'Race still colours South Africa's politics 25 years after apartheid's end' The Conversation, 1 May 2019. Available at: https://theconversation. com/race-still-colours-south-africas-politics-25-years-after-apartheidsend-115735 [Accessed 12/04/2020]

Graham, L. (2020). 'Pandemic underscores gross inequalities in South Africa, and the need to fix them' The Conversation Africa, 5 April 2020. Available at: https:// theconversation.com/pandemic-underscores-gross-inequalities-in-south-africaand-the-need-to-fix-them-135070 [Accessed 12/04/2020]

Hayes, R. M., \& Luther, K. (2018). \# Notallmen: Media and crime victimization. In \# Crime (pp. 123-151). Cham: Palgrave Macmillan.

Head, T. (2019a). 'Fritz Joubert: Criminal history of "sangoma killer" surfaces' The South African, 5 December 2019. Available at: https://www.thesouthafrican.com/ news/off beat/fritz-joubert-criminal-past-court-dates-former-cop/ [Accessed $13 / 04 / 2020]$ 
Head, T. (2019b). 'Fritz Joubert: EFF blame "white privilege" after man murders sangoma' The South African, 2 December 2019. Available at: https://www. thesouthafrican.com/news/who-is-fritz-joubert-murder-anele-eff-reactionmalema/ [Accessed 13/04/2020]

Horwitz, F. M. and Jain, H. (2011). An assessment of employment equity and broad based black economic empowerment developments in South Africa. Equality, Diversity and Inclusion: An International Journal, 30(4), pp. 297-317.

Independent Online. (2019). '\#AmINext trends as SA reels after Uyinene Mrwetyana's murder' Independent Online, 2 September 2019. Available at: https:// www.iol.co.za/news/south-africa/western-cape/aminext-trends-as-sa-reels-afteruyinene-mrwetyanas-murder-31743016 [Accessed 12/04/2020]

Jewkes, R., Levin, J. and Penn-Kekana, L. (2002). Risk factors for domestic violence: findings from a South African cross-sectional study. Social Science \& Medicine, 55(9), pp. 1603-1617.

Keane, F. (2018). 'South Africa's 'toxic' race relations' BBC, 18 December 2018. Available at: https://www.bbc.com/news/world-africa-46071479 [Accessed on $11 / 04 / 2020]$

Kiewit, L. (2019). 'Racism stops rugby's try at uniting South Africa' Mail \& Guardian, 10 October 2019. Available at: https://mg.co.za/article/2019-10-10-racismstops-rugbys-try-at-uniting-south-africa/ [Accessed 13/04/2020]

Lauren Southern. (2018). FARMLANDS (2018) | Official Documentary. [Online Video). Available at: https://www.youtube.com/watch?v=a_bDc7FfItk\& feature=youtu.be [Accessed 12/03/2020]

LuiSpot. (2019). Fritz Joubert Films the murder of Anele Hoyana. [Online Video]. Available at: https://www.youtube.com/watch?v=dmtyBZTqugk [Accessed 13/04/2020]

Mahlomber. (2019) Re: Anele Hoyana murder | Busisiwe Jemsana-Mantashe speaks to SAPS officials. [Video file].Retrieved from https://www.youtube.com/ watch? $\mathrm{v}=\mathrm{aOWI} 2 \mathrm{VCNVuk}$

Maldonado-Torres, N. (2007). On the coloniality of being: Contributions to the development of a concept. Cultural Studies, 21(2-3), pp. 240-270.

Maldonado-Torres, N. (2017). On the coloniality of human rights. Revista Critica de Ciências Sociais, 114, pp. 117-136.

Manderson, L. and Levine, S. (2020). COVID-19, Risk, Fear, and Fall-Out. Medical Anthropology, 39(5), pp. 367-370.

Marie. (2019) Re: Anele Hoyana murder | Busisiwe Jemsana-Mantashe speaks to SAPS officials. [Video file].Retrieved from https://www.youtube.com/ watch? $\mathrm{v}=\mathrm{aOWI} 2 \mathrm{VCNVuk}$

Maylam, P. (2017). South Africa's racial past: The history and historiography of racism, segregation, and apartheid. London: Routledge.

Mbembe, A. (2001). On the Postcolony. Berkeley: University of California Press.

Meigh. (2019) Re: FARMLANDS (2018) | Official Documentary. [Video file].Retrieved from https://www.youtube.com/watch?v=a_bDc7FfItk\&t=16s

Mendes, K., Ringrose, J. and Keller, J. (2018). \# MeToo and the promise and pitfalls of challenging rape culture through digital feminist activism. European Journal of Women's Studies, 25(2), pp. 236-246.

Meyiwa, T., Williamson, C., Maseti, T. and Ntabanyane, G. M. (2017). A twentyyear review of policy landscape for gender-based violence in South Africa. Gender and Behaviour, 15(2), pp. 8607-8617. 
Mignolo, W. D. (2007). Delinking: The rhetoric of modernity, the logic of coloniality and the grammar of de-coloniality. Cultural Studies, 21(2-3), pp. 449-514.

Moletsane, R. (2018). "Stop the war on women's bodies": Facilitating a girl-led march against sexual violence in a rural community in South Africa. Studies in Social Justice, 12(2), pp. 235-250.

Morozov, E. (2011). The net delusion: How not to liberate the world. London: Penguin.

Multimedia LIVE. (2017). Cape Town driver attacked in fit of road rage. [Online Video]. Available at: https://www.youtube.com/watch?v=DL0Zj692Lq4 [Accessed 13/04/2020]

Multimedia LIVE. (2019). SA reacts to Anele Hoyana's murder. [Online Video]. Available at: https://www.youtube.com/watch?v=gP1GFyg3_fI [Accessed 13/04/2020]

Ncube. (2019) Re: SA reacts to Anele Hoyana's murder. [Video file].Retrieved from https://www.youtube.com/watch?v=gP1GFyg3_fI

Ndlovu, M. (2018). Coloniality of knowledge and the challenge of creating African futures. Ufahamu: A Journal of African Studies, 40(2).

Ndlozi, M. (2019). 'Brutal and racist murder of Anele Hoyana by white farmer EFF', PoliticsWeb, 2 December 2019. Available at: https://www.politicsweb.co. za/news-and-analysis/brutal-and-racist-murder-of-anele-hoyana-by-white[Accessed 13/04/2020]

News24 Wire. (2019). "Fritz was not a stranger to us, he was a neighbour of 15 years' Anele Hoyana's family', The Citizen, 4 December 2019. Available at: https:// citizen.co.za/news/south-africa/crime/2214379/fritz-was-not-a-stranger-to-us-hewas-a-neighbour-of-15-years-anele-hoyanas-family/ [Accessed 13/04/2020]

Nicholas, L., \& Agius, C. (2018). \# Notallmen,\# Menenism, Manospheres and Unsafe Spaces: Overt and Subtle Masculinism in Anti-"PC" Discourse. In L. Nicholas and C, Agius (Eds). The Persistence of Global Masculinism (pp. 3159). Cham: Palgrave Macmillan.

Nkanjeni, U. (2019). 'Helen Zille tweets her way into hot water, again and again and again and again' Timeslive, 23 May 2019. Available at: https://www.timeslive. co.za/politics/2019-05-23-helen-zille-tweets-her-way-into-hot-water-again-andagain-and-again-and-again/ [Accessed 13/03/2020]

Nombembe, P. (2019). 'IN HIS OWN WORDS | Luyanda Botha: 'This is how I killed Uyinene'. Sunday Times, 15 November 2019. Available at: https://www.timeslive. co.za/news/south-africa/2019-11-15-in-his-own-words-luyanda-botha-this-ishow-i-killed-uyinene/ [Accessed 12/04/2020]

Parez-Pena, R. (2018). 'Woman becomes first South African imprisoned for racist speech video', New York Times, 28 March 2018. Available at: https://www. nytimes.com/2018/03/28/world/europe/south-africa-racist-speech.html [Accessed 13/04/2020]

Passada, M. N. M. (2019). Discourses analysis by a decolonial perspective. In L, Suciu (Ed). Advances in Discourse Analysis. Available from: https://www. intechopen.com/books/advances-in-discourse-analysis/discourses-analysis-bya-decolonial-perspective

Patterson, S. (1977). The white Africans. African Affairs, 76 (302), pp. 108-111.

Quijano, A. (2000). Coloniality of power and Eurocentrism in Latin America. International Sociology, 15(2), pp. 215-232.

Resende, V. D. M. (2018). Decolonizing critical discourse studies: For a Latin American perspective. Critical Discourse Studies, 18(1), pp. 1-17. 
Rianne. (2019) Re: SA reacts to Anele Hoyana's murder. [Video file].Retrieved from https://www.youtube.com/watch?v=gP1GFyg3_fI

SABC Digital News. (2018a). Reaction to Adam Catzavelos racist rant: Adv. Priscilla Jana. [Online Video]. Available at: https://www.youtube.com/watch?v= cc3MOIuSmKc [Accessed 13/04/2020]

SABC Digital News. (2018b). SAHRC investigates Adam Catzavelos racist rant. [Online Video]. Available at: https://www.youtube.com/watch? $\mathrm{v}=\mathrm{mOjNyiuvUzw}$ [Accessed 13/04/2020]

SABC Digital News. (2019). Anele Hoyana murder | Busisiwe Jemsana-Mantashe speaks to SAPS officials. [Online Video]. Available at: https://www.youtube.com/ watch? $\mathrm{v}=\mathrm{aOWI} 2 \mathrm{VCNVuk}$ [Accessed 13/04/2020]

Salawu, A. ed. (2018). African language digital media and communication. Routledge.

Samaga, R. (2017). 'The real story behind \#menaretrash, South Africa's response to domestic violence' OK Africa, 15 May 2017. Available at: https://www. okayafrica.com/real-story-behind-menaretrash-south-africas-viral-hashtag/ [Accessed 13/04/2020]

Sanger, N. (2019). A matter of race and class: Notes on populist feminism in theorising from the South. Agenda, 33(3), pp. 70-73.

Santos, B. D. S. (2012). Public sphere and epistemologies of the South. Africa Development, 37(1), pp. 43-67.

Santos, B. D. S. (2016). Epistemologies of the South and the future. From the European South: a transdisciplinary. Journal of Postcolonial Humanities, 1, pp. 17-29.

Seleka, N. and Grobbler. (2020). 'Adam Catzavelos gets suspended sentence for k-word rant', News24, 28 February 2020. Available at: https://www.news24. com/SouthAfrica/News/breaking-adam-catzavelos-handed-down-r50-000suspended-sentence-for-k-word-video-20200228 [Accessed 13/04/2020]

Singh, D. (2005). Resorting to community justice when state policing fails: South Africa. Acta Criminologica: African Journal of Criminology \& Victimology, 18(3), pp. 43-50.

Soudien, C. (2010). The reconstitution of privilege: Integration in former white schools in South Africa. Journal of Social Issues, 66(2), pp. 352-366.

St. Simon of Trent. (2019) Re: FARMLANDS (2018) | Official Documentary. [Video file].Retrieved from https://www.youtube.com/watch? $v=a \_b D c 7 F f I t k \& t=16 \mathrm{~s}$

Statcounter. (2020). Social Media Stats South Africa. Available at: https://gs. statcounter.com/social-media-stats/all/south-africa [Accessed 12/04/2020]

Statista. (2020). Digital population in South Africa as of January 2020. Available at: https://www.statista.com/statistics/685134/south-africa-digital-population/ [Accessed 12/04/2020]

Swartz, S., Arogundade, E. and Davis, D. (2014). Unpacking (white) privilege in a South African university classroom: A neglected element in multicultural educational contexts. Journal of Moral Education, 43(3), pp. 345-361.

Tanaka, S. (2019). MEN ARE TRASH. Sister Namibia, 31(3), pp. 26-28.

Taylor, A. (2018). 'Australia looks into resettling white South African farmers who say they are persecuted' Washington Post, 16 March 2018. Available at: https:// www.washingtonpost.com/news/worldviews/wp/2018/03/16/australia-looks-intoresettling-white-south-african-farmers-who-say-they-are-persecuted/ [Accessed $12 / 04 / 2020]$

Tembo, N. M. (2019). The decolonial Mandela: Peace, justice and the politics of life by Sabelo Ndlovu-Gatsheni. Biography, 42(2), pp. 426-430. 
Thamm, M. (2019). 'Unstoppable horror - What are we to do with the rage' Daily Maverick, 28 August 2019. Available at: https://www.dailymaverick. co.za/article/2019-08-28-unstoppable-horror-what-are-we-to-do-with-the-rage/ [Accessed 12/04/2020]

Varjavandi, R. (2017). \# Blessers Must Fall: Youth-led participatory action research and photo story creation on teenage pregnancy, transactional sex and genderbased violence. Agenda, 31(2), pp. 87-98.

Vpro Documentary. (2019). White farmers killings in Africa | VPRO Documentary. [Online Video]. Available at: https://www.youtube.com/watch?v=b-Ubvkep0jQ [Accessed 12/04/2020]

Vuuren, W. V. (2005). Ideologies of racial nationalism: The method in their madness. Politikon, 32(1), pp. 59-81.

Walton, M., \& Leukes, P. (2013). Prepaid social media and mobile discourse in South Africa. Journal of African Media Studies, 5(2), pp. 149-167.

Ward, J. (2018). 'The dangerous myth of 'white genocide' in South Africa' Southern Poverty Law Center, 23 August 2018. Available at: https://www.splcenter.org/ hatewatch/2018/08/23/dangerous-myth-white-genocide-south-africa [Accessed 12/04/2020]

Wasserman, H. (2010). 'We're not like that': Denial of racism in the Afrikaans press in South Africa. Communication: South African Journal for Communication Theory and Research, 36(1), pp. 20-36.

Wasserman, H. (2011). Mobile phones, popular media, and everyday African democracy: Transmissions and transgressions. Popular Communication, 9(2), pp. $146-158$.

We are Social. (2020). DIGITAL 2020: SOUTH AFRICA. Available at: https:// datareportal.com/digital-in-south-africa [Accessed 12/04/2020]

Wicks, J. (2019). 'Penny sparrow dies', Timeslive, 25 July 2019. Available at: https://www.timeslive.co.za/news/south-africa/2019-07-25-penny-sparrow-dies/ [Accessed 13/04/2020]

Wilkinson, K. (2017). 'FACTSHEET: Statistics on farm attacks and murders in South Africa' Africa Check, 8 May 2017. Available at: https://africacheck.org/ factsheets/factsheet-statistics-farm-attacks-murders-sa/ [Accessed 12/04/2020]

Willems, W. (2012). Interrogating public sphere and popular culture as theoretical concepts on their value in African studies. Africa Development, 37(1), pp. 11-26.

Williams, J. (2018). 'Trump's tweet echoing white nationalist propaganda about South African farmers, explained' Vox, 23 August 2018. Available at: https:// www.vox.com/policy-and-politics/2018/8/23/17772056/south-africa-trump-tweetafriforum-white-farmers-violence [Accessed 12/04/2020]

Z D. (2019) Re: SA reacts to Anele Hoyana's murder. [Video file].Retrieved from https://www.youtube.com/watch?v=gP1GFyg3_fI 

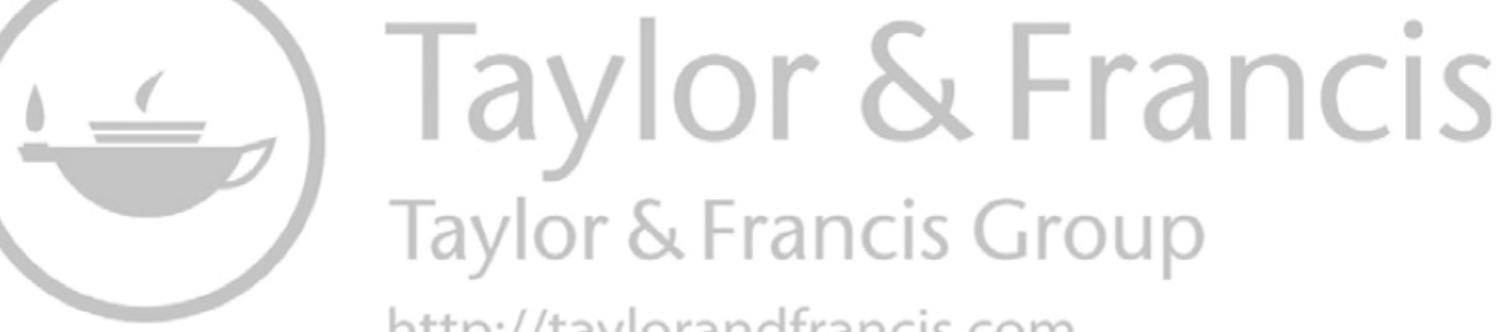

http://taylorandfrancis.com 


\section{Index}

African National Congress (ANC) 71, 209

Afrocentric 15

\#AmINext 211

apartheid xxii, 17, 26-28, 31, 33-36,

$38-42,47,49,52,55,58,67,69$,

$85,127,137,139,197,208$; antiapartheid 185; post-apartheid 6, 42, $52,58,60,64,71,193,197,202$

branding 1, 6, 26, 29

broadcasting $6,48,150,196$

capitalism 1, 35, 41, 139, 142

colonial gaze 93,98

colonialism 48, 55, 60, 69, 124, 160, 194, 207, 212

community engagement 47-48, 50, 61 conflict reporting 6,11

decolonisation xxiv, 1-4, 6, 33, 45, 47, 79, 102, 104, 109, 177, 188, 193

Desai, Rehad 64

Difficult Love 6, 47

digital media 7, 180, 207

documentary film 49, 56, 64, 68, 75, 85, 96-97, 103, 105, 108, 143, 215

Economic Freedom Fighters (EFF) 6, 26

elections xvii, 11, 18, 21, 98, 115, 150, 166, 172, 179, 195, 198, 200, 209

engendered 126, 142, 156, 166

Fanon, Frantz xxii, 27, 35, 71, 181,186

fragmentation 6, 193, 210

gender 2-4, 6, 29, 32, 47, 48, 49, 50, $83,87,109,193,200,201,208,210$, 211,216

Ghana 6, 109, 150, 153, 157 jazz 6, 123

journalism 15, 20, 81, 115, 170, 177, 194, 202

Karnataka 91

Kenya 6, 13, 80, 81, 88, 165, 171, 175, 179

Marikana 35, 64

memory 47, 54, 81, 83, 147

\#MenAreTrash 211

\#MeToo 211

Miners Shot Down 67

Muholi, Zanele 6, 47-48

Mwangi, Boniface 80

Ndlovu-Gatsheni, Sabelo J. 51

performative blackness 6,26

photography $6,47,52,58,79,103$

political disruption 6,179

political icons $4,91,93,95,157$

politicised space 6,165

post-colonial/postcolonial xxiv, 11, 13, 19, 23, 65, 71, 76, 79-88, 98, 193-197, 201, 203, 205; postcolonial gaze 47

public sphere $89,83,87,112,180,196$, 203, 207

radical discourse 207

radio $6,150,153,156,159,161,164,175$

self-censorship 19

Siddis 91

social media 18, 36, 74, 82, 86, 87, 114, $116,156,159,179,182,187,193,201$, 203, 209

socio-cultural 6, 91

\#ThisFlag 6, 181, 182

transformation 6, 61, 128, 156, 174, 193, 194

trauma $47,50,81,88,126$ 


\section{Index}

violence $11,39,48,52,53-56,64$, $76,81-85,98,102,127,135,142,166$, $169,179,207,211,212,213,215,216$ voiceless 7, 150, 207
Zambia 150, 179

ZANU-PF 182

Zimbabwe 6, 11, 15-23, 179-181, 183-188 